$S$

632.95

F2 re

1983

RELATIONSHIPS OF ENDRIN AND OTHER CHLORINATED HYDROCARBON COMPOUNDS TO WILDLIFE IN MONTANA

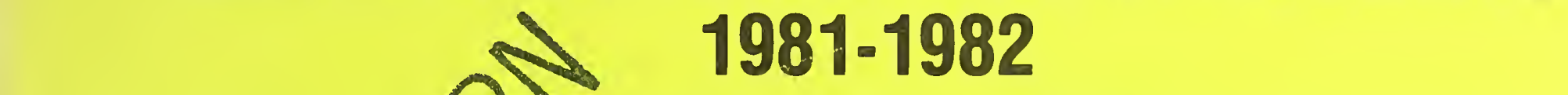

STATE DOCUMENTS COLLECTLOM

JAN 231984

MONTANA STATE ULIARY

1515 E. Gih A':E.

HELENA, MONTANA 59620

Wildlife Division

Montana Department of Fish, Wildlife and Parks

Helena, Montana

September 1983 


\section{THE CONSTITUTION OF THE STATE OF MONTANA}

\section{Preamble}

We the people of Montana are grateful to God for the quiet beauty of our state, the grandeur of our mountains, the vastness of our rolling plains, and desiring to improve the quality of life, equality of opportunity and to secure the blessings of liberty for this and future generations do ordain and establish this constitution.

\section{Article II \\ Bill of Rights}

Section 3. Inalienable rights. All persons are born free and have certain inalienable rights. They include the right to a clean and healthful environment and the rights of pursuing life's basic necessities, enjoying and defending their lives and liberties, acquiring, possessing and protecting property, and seeking their safety, health and happiness in all lawful ways. In enjoying these rights, all persons recognize corresponding responsibilities.

-Adopted by the People of Montana, June 6, 1972. 
RELATIONSHIPS OF ENDRIN AND OTHER CHLORINATED HYDROCARBON COMPOUNDS TO WILDLIFE IN MONTANA, 1981-1982

$$
\text { by }
$$

$$
\begin{gathered}
\text { Philip Schladweiler } \\
\text { and } \\
\text { John P. Weigand }
\end{gathered}
$$

Wildlife Division

Montana Department of Fish, Wildlife, and Parks Helena, Montana

$$
\begin{gathered}
\text { with financial assistance from } \\
\text { Ducks Unlimited, Inc. } \\
\text { September } 1983
\end{gathered}
$$




\section{Digitized by the Internet Archive in 2016}




\section{FOREWORD}

The 1981 Endrin Issue in Montana involved the people and the government agencies managing and promoting two of the state's most important resources - agriculture and wildlife. Through all of the complex testimony, technical analyses, and conflicting opinions since Montanans became aware of endrin contamination during the spring of 1981 , one central fact has been predominant - the problem was consequential to the state's largest industry and Montana's priceless wildlife resources.

This report outlines some of the events which led to, and occurred during and following the extensive application of endrin to grain fields during the spring of 1981 in Montana. It also presents information concerning residues of heptachlor, heptachlor epoxide, PCB's and 14 other chlorinated hydrocarbon compounds which were coincidentally detected in wildife tissues tested for endrin.

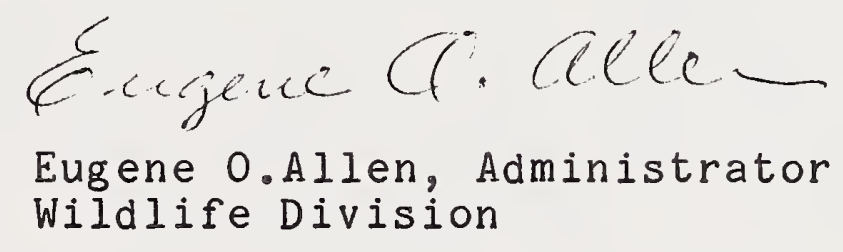





\section{ABSTRACT}

The chain of events which generated the 1981 Endrin Issue in Montana began with an abnormally mild 1980-1981 winter, an early, mild, dry spring in 1981, and the early widespread emergence of army and pale western cutworms in eastern and central Montana. The traditional insecticide for cutworm control since 1954 was endrin. Endrin sales by pesticide dealers were sufficient to treat at least 98,848 acres of small grains, principally winter wheat. Because of different endrin application rates, unknown volumes of endrin stored on farms and ranches, and other chemicals used, the total acreage treated with all chemicals was estimated to have approached 200,000 acres. Studies to evaluate endrin impacts on local aquatic and terrestrial wildlife populations were largely negated because of delays in locating treated fields. Concern for the welfare of humans and predatory wildlife that might consume endrin-contaminated wildlife prompted collecting and testing of 1,191 tissues from various wildife species. Endrin residue monitoring during late April 1981November 1982 involved principally fat, meat, liver, and brain tissues from 4 species of big game, 5 of upland game birds, 13 of small mammals, 12 of waterfowl, 6 of other aquatic and migratory game birds, 6 of raptors, 13 of passerines, and several miscellaneous samples. Initial sampling during 1981-1982 was somewhat at random, while later sampling was concentrated on known 1981 treated areas or those sites from which endrin-positive samples had been collected earlier. Most of the high residues detected were from known treated areas. Maximum endrin residues in fat from those wildlife groups tested were: $0.53 \mathrm{ppm}$ in a pronghorn, $22.9 \mathrm{ppm}$ in a sharp-tailed grouse, $0.01 \mathrm{ppm}$ in a cottontail rabbit, $2.56 \mathrm{ppm}$ in a ruddy duck, $0.64 \mathrm{ppm}$ in a coot, $0.33 \mathrm{ppm}$ in a harrier, and $0.16 \mathrm{ppm}$ in a horned lark. Field studies during summer 1982 on the effects of chlorpyrifos, permethrin, and endrin on wildlife showed permethrin was more efficacious than the other compounds in controlling cutworms and, although it was toxic to aquatic invertebrates it appeared to be the least toxic to terrestrial wildlife. Maximum endrin levels in fat (ppm wet weight) of animals collected in those studies were: $0.24 \mathrm{ppm}$ in a black-tailed prairie dog $41 / 2$ weeks postspray, 3.00 ppm in a baldpate $41 / 2$ weeks postspray, and 3.57 and 3.03 ppm in prairie horned larks 4-5 days and 2 weeks postspray, respectively. Endrin poisoning of small mammals within 3-4 days postspray, and relatively high endrin residues in fat of birds collected 4-5 days postspray indicated rapid assimilation of endrin by both groups. Residues of 17 other chlorinated hydrocarbon compounds involving 9 parent compounds and their isomers, were detected and reported by a private laboratory that tested tissues (for endrin) submitted from late 1981-1982 collections. Because of the persistence of this group of compounds, it was not considered unusual to detect low residue levels in wildlife samples. The high residue levels that occasionally occurred were considered unusual, and were of most concern. Maximum residues, on a wet weight basis, of these compounds in fat samples were: $0.25 \mathrm{ppm}$ 
heptachlor in a harrier, 53.0 ppm heptachlor epoxide in a mourning dove, $50.1 \mathrm{ppm}$ polychlorinated biphenyl in a blue-winged teal, 0.82 ppm alpha-chlordane in a shoveler, 0.68 ppm gammachlordane in a mallard, 0.37 ppm beta-nonachlor in an eared grebe, 0.60 ppm trans-nonachlor in a mourning dove, 2.23 ppm oxychlordane in a horned lark, 8.27 ppm DDT in a pintail, 1.00 ppm DDD in a white pelican, 33.7 ppm DDE in a harrier, $2.08 \mathrm{ppm}$ dieldrin in a red-tailed hawk, $3.95 \mathrm{ppm}$ hexachlorobenzene in a vesper sparrow, $0.09 \mathrm{ppm}$ lindane in a great horned ow 1 and a snow bunting, 0.32 ppm benzene hexachloride in a long-eared owl, and $6.01 \mathrm{ppm}$ mirex in a mallard. Maximum 12-ketoendrin residues $(0.96 \mathrm{ppm})$ occurred in the whole body of a deer mouse. Each parent compound (endrin, heptachlor, polychlorinated biphenyl, DDT, dieldin, hexachlorobenzene, benzene hexachloride, chlordane, and mirex) and/or its metabolites was found in resident wildlife in Montana indicating exposure is possible both within Montana as well as outside the state. The significance of the frequencies and levels of all residues detected are discussed as they relate to the welfare of local wildlife populations and their potential hazards to humans who eat insecticide-contaminated meat. Recommendations for cancelling the use of the most toxic of these persistent compounds, the use of safe and effective alternative insect control methods, continued residue monitoring, and other aspects of the initial issue are presented. 


\section{ACKNOWLEDGEMENT}

These studies could not have been successfully undertaken without the interest and participation by many Montana Department of Fish, Wildlife and Parks employees. Personnel who contributed significantly in the field included: M.A. Anderson, T.W. Butts, D.A. Childress, A. Dood, A.A. Elser, F.G. Feist, D.L. Flath, R.L. Furber, J.T. Herbert, B. Hildebrand, T.L. Hill, T.C. Hinz, S.J. Knapp, D.A. Kohlmoos, J.W. Logan, N.S. Martin, H. Nyberg, J.L. Ramsey, R. Schoening, R.P. Stoneberg, R.P. Stordahl, J. Swenson, K. Walcheck, C.R. Watts, and H.J. Wentland. Assistance in preparing specimens for residue analyses by laboratories included many of the above individuals, plus R.C. McFarland, D.F. Pac and D.F. Palmisciano. Mr. McFarland also coordinated initial record keeping efforts and was instrumental in computerizing residue data as they became available. Administrative support was given by E.O. Allen, R.R. Fliger, R.L. Johnson, R.G. Marcoux, K.G. Seaburg, N.A. Thoreson, and the Director, J.W. Flynn. G.R. Phillips provided the aquatic wildlife segments and data in this report.

We thank T.W. Mussehl for his early efforts in recognizing the potential hazards to wildlife and humans, for advocating and coordinating initial statewide sample collections, preparing and shipping wildlife tissues to laboratories, and for his editorial suggestions on this report.

J.D. Cada designed and conducted the telephone interview survey of hunters to evaluate the level of hunter awareness of pesticide contamination of game birds following 1982 hunting seasons.

D. Sexton and T. Warren contributed the layout and photographs for the front cover, and D. Bourquin and J. Lightbody did the printing of the report.

The interest, support, and decisive actions by members of the Montana Fish and Game Commission is gratefully acknowledged.

We especially acknowledge the cooperation of the private landowners who permitted us to collect wildlife from their lands.

Recognition is given to D. Quist, Montana Department of Agriculture, who catalogued specimens and assured direct delivery to that department's EPA-approved laboratory in Bozeman, Montana; L. Torma and his staff of analytical chemists performed the necessary residue analyses during 1981. G.A. Algard and O.G. Bain were especially helpful in coordinating and participating in field studies in 1982. W.G. McOmber (former Director) and G.L. Gingery provided administrative support and information on locations of endrin-treated fields, and were instrumental in cancelling the state registration of endrin for use on grasshoppers in grainfields in the fall. The Montana Department of Agriculture also provided financial support to help offset costs of preparing this report. 
Montana Department of Health and Environmental Sciences personnel, under the directorship of J.J. Drynan, tested fish and water samples for endrin residues, provided information on federal action levels for various pesticides in human food, and interpreted pesticide residues found in wild game meat from human health perspectives.

We greatly appreciated the extraordinary assistance provided by R.L. Johnson, D.F. Hughes and their staff, HAZLETON. RALTECH, INC. (Madison, WI.), via their explanations of analyti.. cal methodology used in testing for the various pesticide residues, their quality control during testing, and their close communications during our studies. They also alerted us to the occurrence of pesticide residues (besides endrin) in Montana's wildife samples.

L.C. McEwen, Rocky Mountain Field Station, Patuxent Wildlife Research Center (Ft. Collins, Co.), was extremely helpful in guiding investigators to endrin-wildlife literature and in generating U.S. Fish and Wildlife service support for testing mourning dove, black bear, and fish samples for endrin residues in 1981. He also participated in the 1982 field studies on the effects of endrin, chlorpyrifos, and permethrin on wildlife, and supervised analyses of brain tissues for cholinesterase inhibition. Personnel on the Benton Lake, Bowdoin, and Medicine Lake National Wildlife Refuges in central and eastern Montana collected and submitted waterfowl samples for endrin residue analyses in 1981. R.J. Hall, T.G. Lamont, and W.L. Reichel, Patuxent Wildlife Research Center, supervised residue analyses and provided results from all of those samples. H.W. Miller, Central Flyway Representative, distributed pesticide residue data from migratory birds among the states, which encouraged other states to collect and test additional birds for pesticide residues.

The assistance of $H$. Spencer, Toxicologist, EPA (Washington, D.C.) in interpreting the early endrin residues in game species in 1981 as they related to implications to human health is gratefully acknowledged. M.W. Lammering and his staff, EPA Regional Laboratory (Denver, Co.), also performed some of the residue analyses from 1981 wildlife tissues.

We gratefully acknowledge the intense interest and financial support of Ducks Unlimited, Incorporated, and especially the support of their Executive Director Dale Whitesell, for the continued endrin monitoring effort through 1982.

The interest and understanding of the Federal Aid in Wildife Restoration Regional staff in Denver, Colorado, during these studies is also acknowledged.

Typing of the manu ript for publication was by R.L. Slavinsky and L.oM. Todd. 


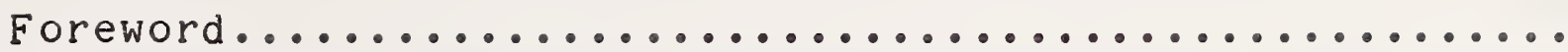

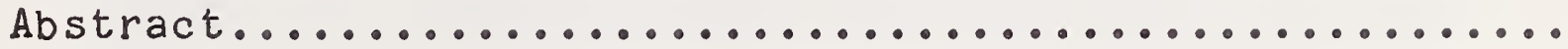

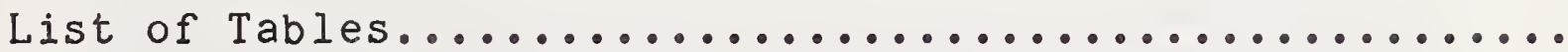

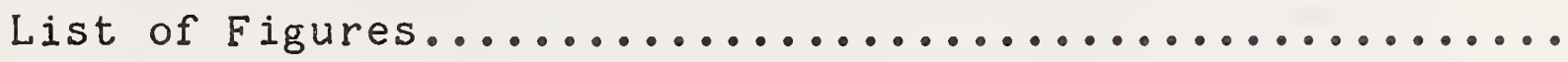

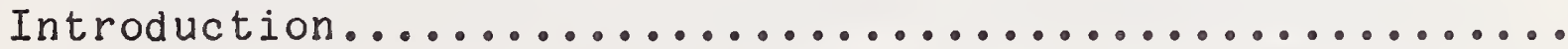

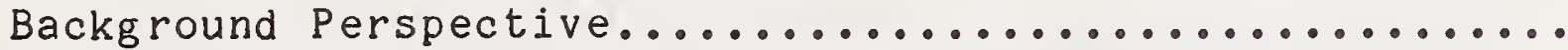

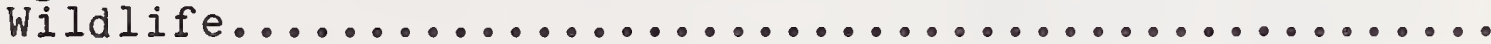

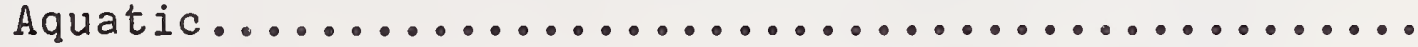

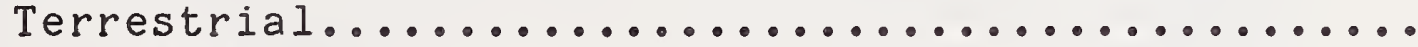

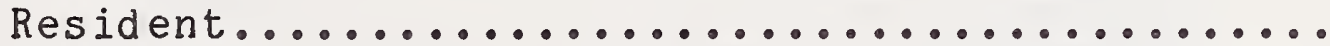

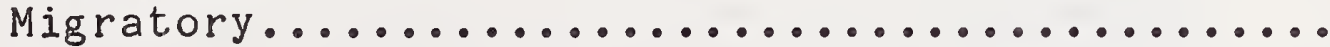

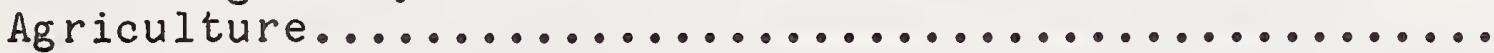

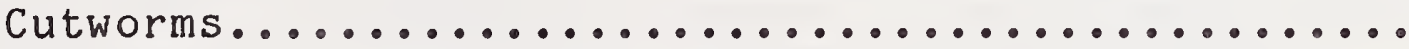

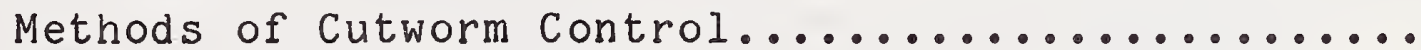

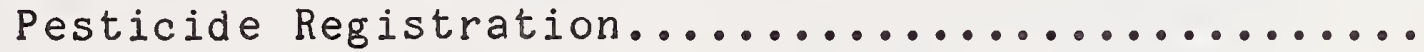

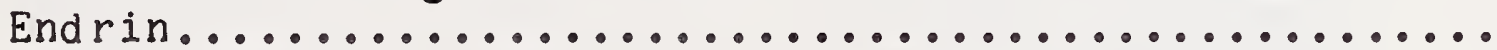

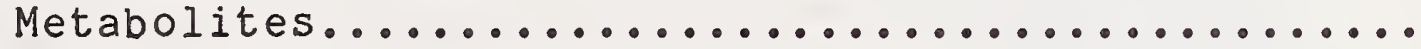

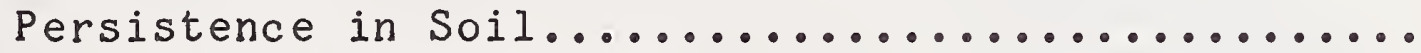

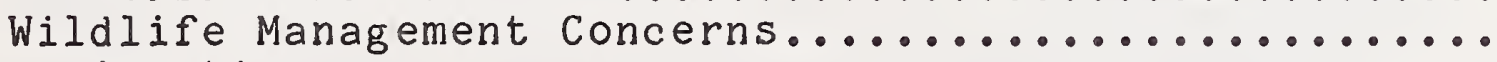

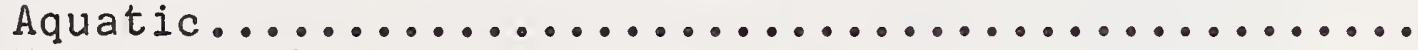

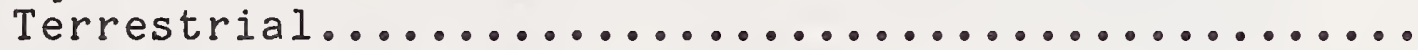

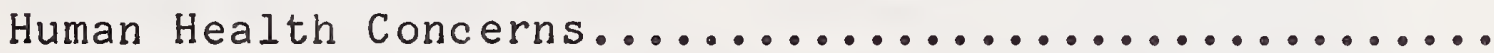

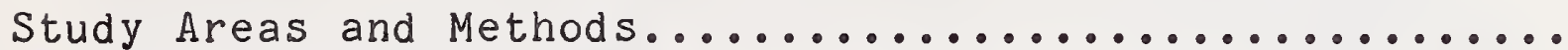

Monitoring 1981 Operational Endrin Spraying..........

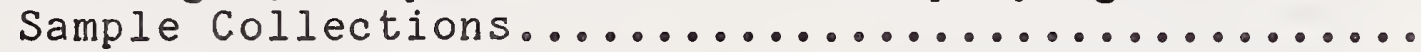

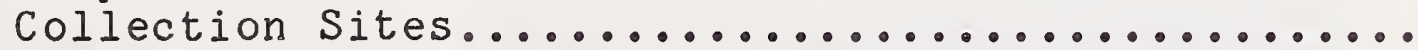

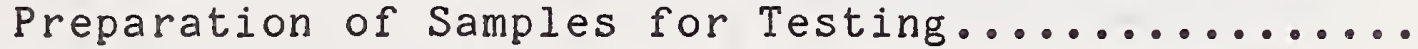

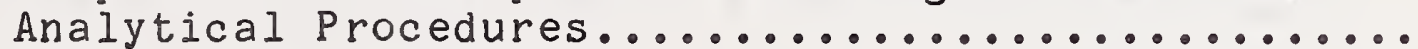

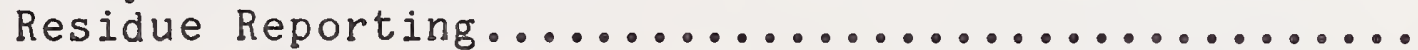

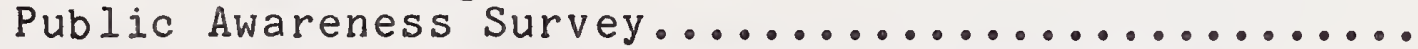

1982 Alternative Insecticide-Wildlife Studies.........

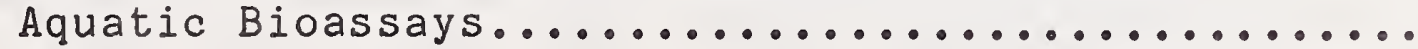

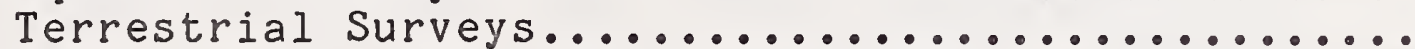

Other Chlorinated Hydrocarbon Compounds..............

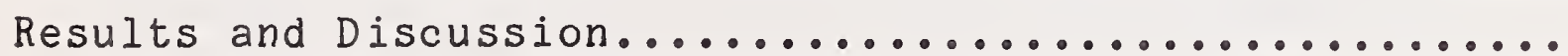

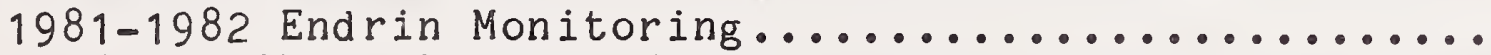

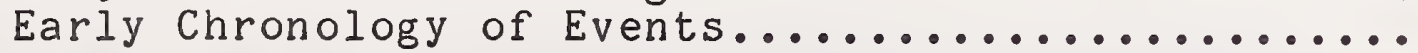

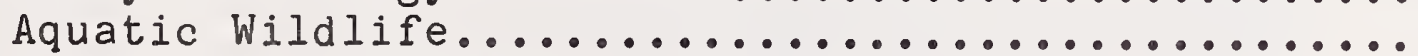

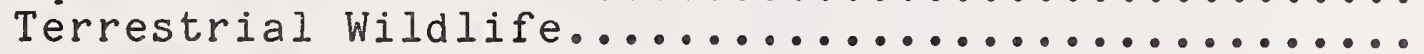

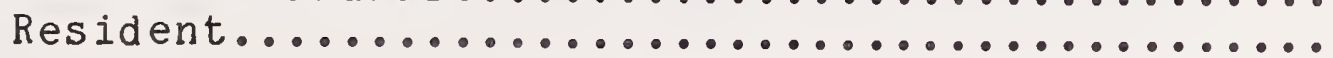

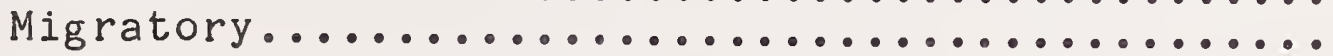

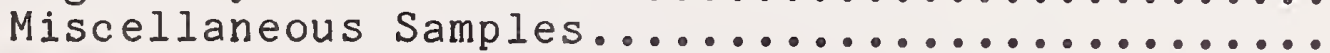

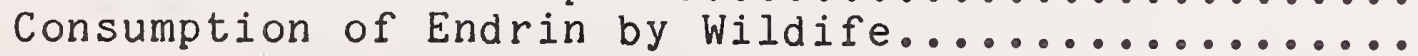


TABLE OF CONTENTS

(Continued)

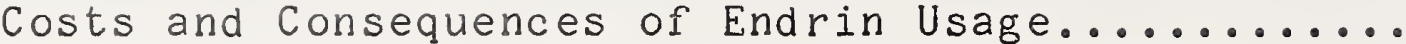

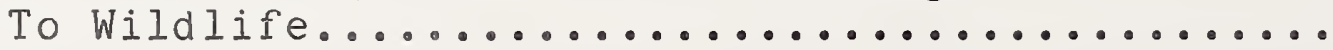

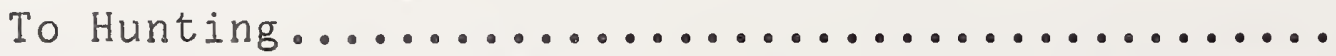

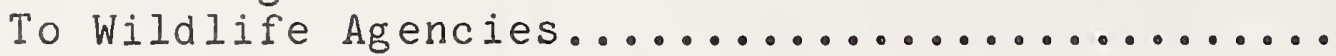

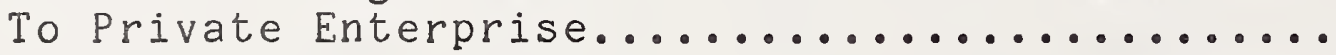

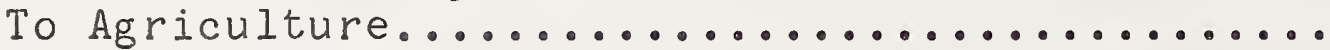

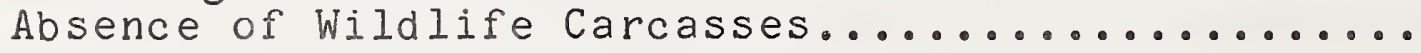

Continued Registration of Endrin by the EPA........ 1982 Alternative Insecticide-Wildlife Studies........

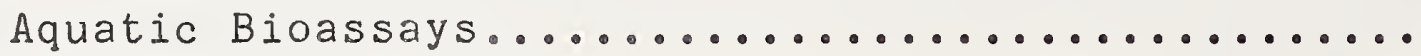

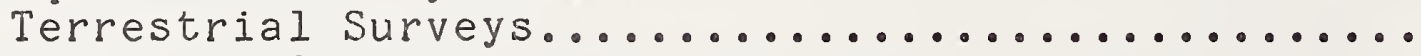

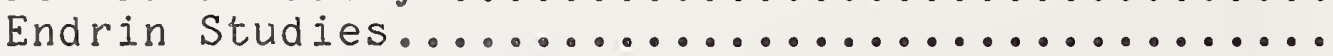

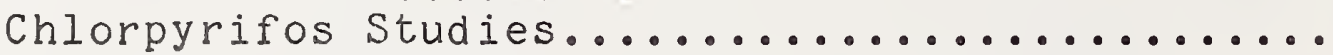

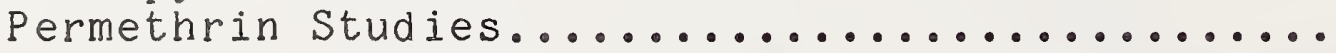

Comparative Efficacies of Tested Insecticides...

other Chlorinated Hydrocarbon Compounds.............

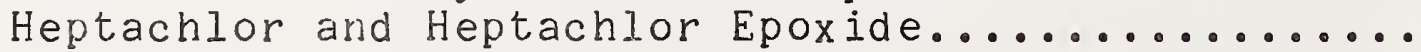

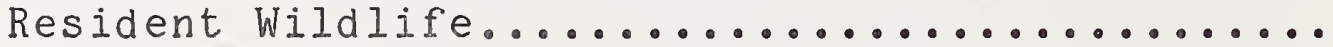

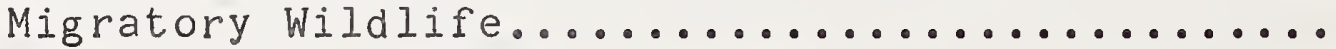

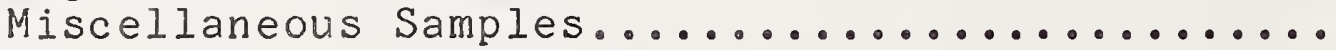

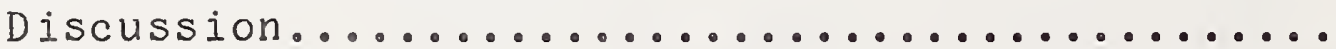

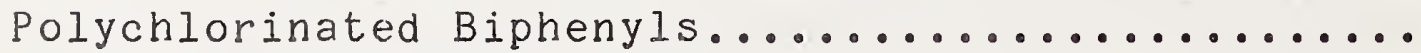

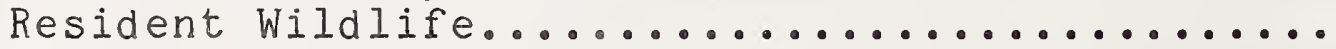

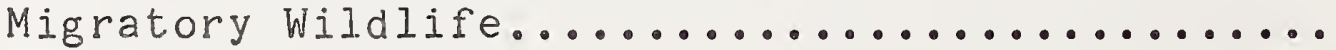

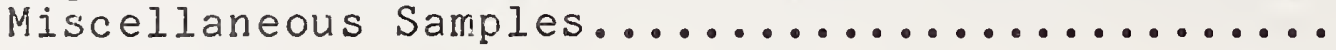

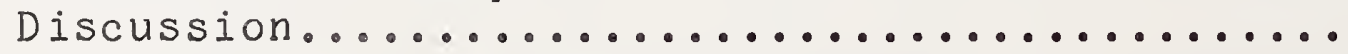

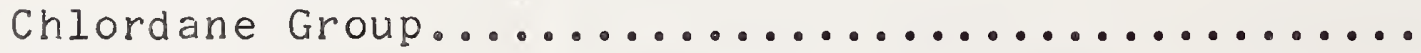

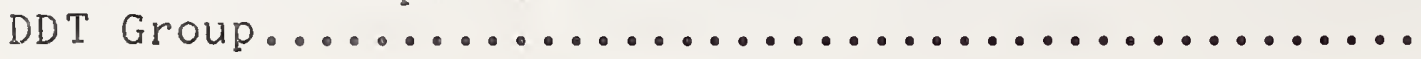

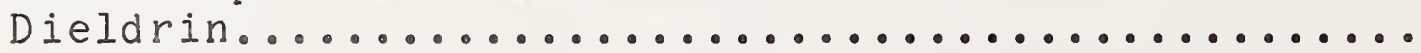

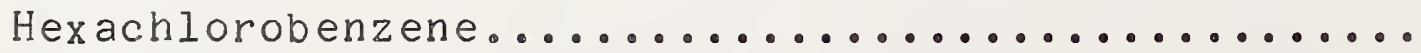

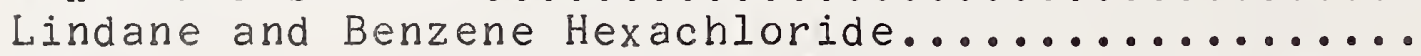

Mirex.................................

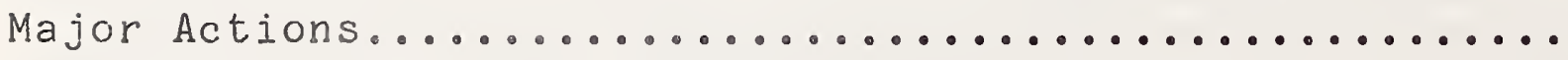

Page

69

69

69

74

75

75

77

78

80

82

82

82

90

92

92

94

94

96

98

104

104

113

113

114

122

122

129

133

139

141

143

145

147

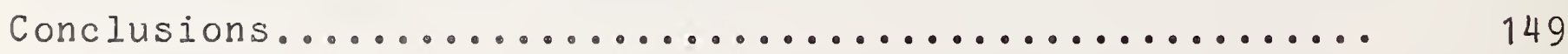

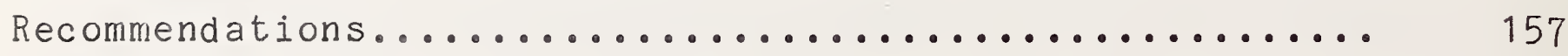

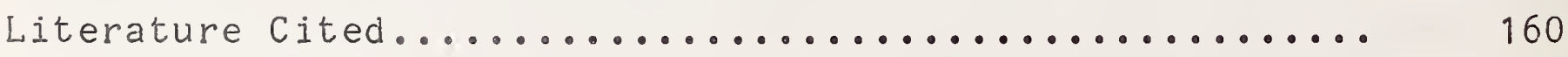

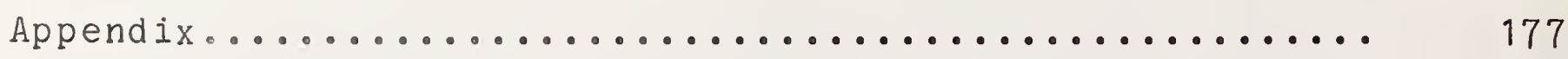




\section{LIST OF TABLES}

No.

Page

Summary of statewide hunting statistics for deer and pronghorn in Montana, 1976-1981.

Annual harvests of four species of upland game birds in Montana, 1976-1981.

Waterfowl species, activities, and spring migration dates in Montana.

Median tolerance limits to fish, and application rates necessary to reach those levels, of four chlorinated hydrocarbon insecticides currently used in Montana.

Acute toxicity of endrin to 12 species of fish which occur in Montana.

Acute toxicity of endrin to $10 \mathrm{kinds}$ of aquatic invertebrates which occur in Montana.

Acute oral toxicity of endrin to birds and mammals.

Endrin residues in fish from selected locations in Montana during 1981.

Summary of endrin residues detected in tissues of big game during monitoring of spring 1981 endrin applications.

Summary of endrin residues detected in tissues of upland game birds during monitoring of spring 1981 endrin applications.

Summary of endrin and ketoendrin residues detected in tissues of small mammals during monitoring of spring 1981 endrin applications.

Summary of endrin residues detected in tissues of waterfowl during monitoring of spring 1981 endrin applications.

Summary of endrin residues detected in tissues of other aquatic birds and migratory game birds during monitoring of spring 1981 endrin applications. 


\section{LIST OF TABLES}

(Continued)

Nㅡㅇㅡ.

Page

14 Summary of endrin residues detected in tissues of raptors during monitoring of spring 1981 endrin applications.

Summary of endrin residues detected in tissues of passerine birds during monitoring of spring 1981 endrin applications.

16 Summary of endrin residues detected in miscellaneous samples during monitoring of spring 1981 endrin applications.

Amounts of endrin-contaminated vegetation/food to be ingested to attain LD $50^{\prime}$ s in four species of Montana wildife.

Summary of the numbers of resident and nonresident game bird hunting licenses issued in Montana, 1976-1981.

Summary of numbers of upland game bird hunters afield, days hunted, and birds harvested in Montana, 1976-1981.

Summary of numbers of federal waterfowl hunting stamps sold, hunters afield, hunter days, and waterfow 1 harvested in Montana, 1976-1981.

Revenues generated by the sale of game bird hunting licenses to the Montana Department of Fish, Wildife and Parks, 1976-1981.

Summary of wheat acreages, yields, price per bushel, and crop value in Montana, 1981.

Comparative toxicities of selected insecticides to wildife. permethrin.

Summary of endrin residues detected in tissues of migratory wild I ife at prespray and various postspray intervals following 1982 endrin applications.

Summary of endrin residues detected in tissues of resident wildife at various postspray intervals following 1982 endrin applications. 


\section{LIST OF TABLES}

(Continued)

Ne.

Page

27

Summary of heptachlor epoxide residues detected 97 in tissues of upland game birds in Montana, 1981-1982.

Summary of heptachlor epoxide residues detected in tissues of small mammals in Montana, 19811982 .

Summary of heptachlor epoxide residues detected in tissues of waterfowl in Montana, 1981-1982.

100

Summary of heptachlor epoxide residues detected in tissues of other aquatic birds and migratory game birds in Montana, 1981-1982.

Summary of heptachlor epoxide residues detected in tissues of raptors in Montana, 1981-1982.

Summary of heptachlor epoxide residues detected in tissues of passerine birds in Montana, 19811982 .

Summary of PCB residues detected in tissues of small mammals in Montana, 1981-1982.

Summary of PCB residues detected in tissues of waterfow I in Montana, 1981-1982.

Summary of PCB residues detected in tissues of other aquatic birds and migratory game birds in Montana, 1981-1982.

Summary of $P C B$ residues detected in tissues of raptors in Montana, 1981-1982.

Summary of $P C B$ residues detected in tissues of passerine birds in Montana, 1981-1982.

Summary of PCB residues detected in miscellaneous samples in Montana, 1981-1982. birds. 



\section{LIST OF FIGURES}

No.

Pag $\underline{e}$

1 Percentage distribution by state and province of

direct recoveries of Canada geese banded $(\mathrm{N}=2,656)$ in Montana in summer.

2 Percentage distribution by state and province of direct recoveries of mallards banded $(N=1,594)$ in Montana in summer.

3 Percentage distribution by state and province of direct recoveries of pintails banded $(\mathrm{N}=670)$ in Montana in summer.

4 Distribution of winter and spring wheat by county in Montana, 1979.

5 Counties from which economic infestations of army cutworm have been reported in small grains in Montana, 1903-1982.

6 Counties from which economic infestations of pale western cutworm have been reported in small grains in Montana, 1915-1982.

7 Reservoir 1 in sagebrush-grassland at Site 1.

8 Reservoir 2 (Site 1) in sagebrush-grassland with drainage from a nearby endrin-treated wheat field.

9 Reservoir 3 (Site 1) in sagebrush-grassland bordered by an endrin-treated wheat field.

10 Reservoir at Site 5 immediately below an endrintreated wheat field.

11 Permethrin-treatment study area near Vaughn.

12 Map of Lavina study area showing location of various insecticide treatments.

13 Chronology of 1981 endrin spraying and subsequent events and endrin residues in vegetation and wildlife in Montana.

14 Locations where fish were sampled for endrin analyses in 1981. 


\section{LIST OF FIGURES}

(Continued)

No.

15 Distribution of 1981-1982 sampling sites used to monitor endrin residues in terrestrial wildlife in Montana following 1981 endrin applications.

16 Reported acres of wheat treated with heptachlor by county in Montana, 1981. 


\section{INT RODUCTION}

A mild winter (1980-1981) followed by warm, dry spring conditions throughout eastern Montana resulted in earlier than normal activities of army and pale western cutworms. Agricultur alists have traditionally, used endrinl/, a persistent chlorinated hydrocarbon insecticide to combat those economically-damaging pests. Montana Department of Agriculture (MDA) personnel indicated in March 1981 that endrin might be applied on up to 275,000 acres of grainfields in eastern Montana that spring. Ultimately, about 200,000 acres were treated, at least half with endrin.

Endrin's documented hazard to wildlife and affinity to fat indicated that extensive spraying could seriously impact the management of $f i s h$ and wildlife. Belated information on locations of endrin-treated fields precluded timely field studies to determine immediate impacts on those resources. Because those field assessments could not be conducted, endrin residues which might persist in game meat and be consumed by hunters that fall became a primary concern. Studies were necessarily limited to postspray residue analyses of a wide variety of wildlife beginning in late April 1981.

Initial objectives in monitoring endrin residues in Montana wildlife tissues in 1981 were to document: (1) species which had assimilated endrin, (2) levels of endrin which had accumulated, and (3) persistence of endrin residues in those species. It was oriented initially toward consumability of wildlife. In answering the public health questions the resulting data were also significant because of possible impacts to animal welfare. This included the following concerns:

1. most female mule deer, white-tailed deer, and pronghorn were experiencing the last half of pregnancies; the impacts of endrin on gestation physiology was unknown;

2. Hungarian partridge and sharptails were breeding and initiating early nests in March and April; i.e. base breeding populations and production from early nests could be reduced;

3. pheasants were rebuilding fat reserves prior to breeding in May, and could assimilate endrin which could adversely impact base breeding populations; and

1/ Chemical nomenclature of chlorinated hydrocarbon insecticides is given in Appendix A. 
4. waterfowl and nongame and endangered species of birds were migrating to and through Montana.

Detection of endrin in wild Iife at levels that exceeded the U.S. Department of Agriculture (USDA) action levels for domestic meats resulted in continued sampling at many of the same sites through the fall of 1982. Objectives of the continued collections were to:

1. determine persistence of endrin applied in 1981 in wildlife tissues;

2. document endrin levels in resident and migratory wild life during breeding and rearing seasons; and

3. provide background data on endrin residues in wildlife in the event that endrin would be applied again that fall or in 1982 .

Subsequent discovery of heptachlor and heptachlor epoxide, known to be carcinogenic to humans, plus 15 other chlorinated hydrocarbon compounds, including polychlorinated biphenyls (PCB'S), in wildlife tissues generated additional concern. Residue levels of those compounds, and their potential impacts on Montana wildlife and on people who might consume those wildlife are reported.

Recognizing the need for substitute methods of cutworm control if the use of endrin was terminated, the Montana Department of Fish, Wildlife \& Parks (MDFWP) and MDA implemented a field study of the effects of chlorpyrifos and permethrin on cutworms and wildlife. That study, which also utilized endrin as a "standard", was done during May-September 1982. Objectives of the study were to determine: (1) the concentrations of insecticides reaching the ground downwind from spray areas, (2) the biological impacts of those insecticides on aquatic life at various downwind intervals; (3) the efficacy of each compound in controlling cutworms; (4) the impact of each compound on various species of wildlife; and (5) levels of each compound assimilated by these species in, and immediately adjacent to, treated areas.

This report summarizes the findings of the 1981-1982 monitoring and field studies and discusses implications to fish and wild life management, including human consumption of contaminated wild life. 


\section{BACKGROUND PERSPECTIVE}

\section{Wildlife}

Montana is inhabited by 585 species of vertebrate wildife during one time or another each year. They include 81 species of fish, 101 of mammals, 371 of birds, and 16 each of amphibians and reptiles. Emphasis of the present studies involved those which might reasonably be expected to contact endrin applied to grainfields in 1981; they included 52 (64\%) of the fish species, $61(61 \%)$ of the mammals, 104 (28\%) of the birds, 9 (56\%) of the amphibians, and 11 (69\%) of the reptiles.

Wildlife is an important and cherished part of Montana's heritage. It is a renewable and publicly-owned resource. Demand for wildlife has traditionally been high, and that demand is increasing; according to the MDFWP Wildlife Strategic Plan approximately $70 \%$ of all Montanans "use" wildlife, with half of that demand accounted for by hunters (Mussehl et al. 1978). Because $64 \%$ of Montana's land (excluding national parks and Indian reservations) is privately owned, the relative abundance of many wildlife species depends largely on the uses and management practices employed on those lands. Expansion and intensification of land uses which reduce the carrying capacity of wildlife habitats have been identified as major wildlife management problems (Mussehl et al. 1978). Part of that problem involves the application of pesticides to crop and range lands.

These investigations address the agricultural use of endrin and heptachlor to control cutworms and wireworms, respectively, in cereal grains, primarily winter wheat. Chlorinated hydrocarbon insecticides are noted for their persistence in the environment, affinity for fat, and high toxicity. They have historically caused negative effects to wildlife, and have been implicated in threats to human health. Members of this chemical family which have been banned include DDT, chlordane, dieldrin, endrin (except on cotton west of Interstate 35, as a rodenticide in orchards, as an avicide, and for cutworm control in cereal grains), and heptachlor (other than as a seed dressing). Our studies were aimed at some traditional agricultural chemicals that were in the process of being replaced when discovery of their elevated residues in Montana's wildlife precipitated public concern.

\section{Aquatic}

Twenty-four game and 57 nongame fish species inhabit Montana's lakes, reservoirs, rivers, and streams. All are dependent on insects for food sometime during their life cycle; prey species rely heavily on insects as food. Thirteen (54\%) of the game and $39(68 \%)$ of the nongame species have a reasonable opportunity to contact endrin applied to grainfields. Only those 
species which were tested for endrin residues will be discussed in this report. Except for snapping turtlestl which are occasionally eaten by humans, no other reptile or amphibian species were tested for endrin residues.

\section{Terrestrial}

\section{Resident}

Big Game. Only 3 of Montana's 12 big game species were considered to be susceptible to assimilation of endrin applied to cultivated crops: mule deer, white-tailed deer, and pronghorn antelope. Although generally not closely associated with cultivated fields, 2 black bears which were depredating beehives near grain fields in southcentral Montana were also tested for endrin residues.

Deer are the most sought after big game animals in the state (Table 1), providing an annual average (1976-1981) of 899,000 hunting recreation days (firearms and archery seasons) to 145,000 hunters, and yielding a harvest of 66,000 animals per year. Pronghorn are the third ranked big game species, providing an annual average of 50,600 total hunting days for 19,600 hunters, with a harvest of 14,400 animals.

Mule deer are widely distributed over Montana, occurring in every county and at some time during the year on 119,380 mi2, or about $91 \%$ of the state (excluding national parks and Indian reservations). They inhabit the broken-forested mountains, mountain foothills, river breaks, and prairies. Because some foothill and rangeland habitats have been converted to cultivated grain and hay crops, mule deer could readily encounter endrintreated fields. Land ownership of mule deer range is $56 \%$ private, $38 \%$ public (i.e. federal), and $6 \%$ state school land; a higher percentage of their range is in private ownership in the eastern part of the state.

White-tailed deer occur on about $38,400 \mathrm{mi}$, or $29 \%$ of Montana (excluding national parks and Indian reservations). Land ownership of their range is $65 \%$ private, $32 \%$ public, and $3 \%$ state. In central and eastern Montana, 82-93\% of whitetail habitats are privately owned. Over $75 \%$ of the annual whitetail harvest is estimated to come from private land. Whitetails inhabit most drainages of Montana that have tree and/or shrub cover, plus the heavy coniferous-forested mountains and foothill areas. Because of their close association with agricultural areas in central and eastern Montana, whitetails were considered the big game species most likely to contact endrin treatments.

2) Common and scientific names of Montana wildlife mentioned in the text are given in Appendix B. 
Table 1. Summary of statewide hunting statistics for deer and pronghorn in Montana, 1976-1981.

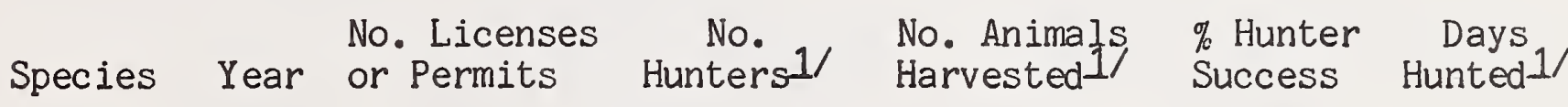

Firearms Hunting

\begin{tabular}{|c|c|c|c|c|c|c|}
\hline Deer & $\begin{array}{l}1976 \\
1977 \\
1978 \\
1979 \\
1980 \\
1981\end{array}$ & $\begin{array}{l}127,813 \\
134,665 \\
137,504 \\
149,513 \\
160,964 \\
161,527\end{array}$ & $\begin{array}{l}114,849 \\
120,798 \\
125,054 \\
140,230 \\
151,918 \\
154,068\end{array}$ & $\begin{array}{l}43,291 \\
54,143 \\
53,933 \\
64,270 \\
85,164 \\
89,003\end{array}$ & $\begin{array}{l}44 \\
45 \\
43 \\
46 \\
56 \\
58\end{array}$ & $\begin{array}{l}811,179 \\
834,423 \\
786,489 \\
907,971 \\
810,680 \\
844,617\end{array}$ \\
\hline Pronghorn & $\begin{array}{l}1976 \\
1977 \\
1978 \\
1979 \\
1980 \\
1981\end{array}$ & $\begin{array}{l}27,167 \\
27,213 \\
22,285 \\
16,811 \\
18,384 \\
22,188\end{array}$ & $\begin{array}{l}23,273 \\
24,214 \\
18,393 \\
14,170 \\
16,104 \\
18,973\end{array}$ & $\begin{array}{l}17,298 \\
18,528 \\
13,471 \\
10,039 \\
12,016 \\
14,954\end{array}$ & $\begin{array}{l}69 \\
77 \\
73 \\
71 \\
75 \\
79\end{array}$ & $\begin{array}{l}69,819 \\
72,642 \\
55,179 \\
28,340 \\
32,208 \\
37,946\end{array}$ \\
\hline \multicolumn{7}{|c|}{ Archery Hunting } \\
\hline Deer & $\begin{array}{l}1976 \\
1977 \\
1978 \\
1979 \\
1980 \\
1981\end{array}$ & $\begin{array}{r}7,665 \\
9,110 \\
10,424 \\
11,325 \\
13,883 \\
15,407\end{array}$ & $\begin{array}{r}6,000 \\
7,143 \\
7,849 \\
12,096 \\
14,081 \\
14,725\end{array}$ & $\begin{array}{r}486 \\
826 \\
865 \\
850 \\
1,398 \\
1,512\end{array}$ & $\begin{array}{r}8 \\
12 \\
11 \\
7 \\
10 \\
10\end{array}$ & $\begin{array}{l}37,800 \\
48,572 \\
60,437 \\
83,264 \\
71,497 \\
90,752\end{array}$ \\
\hline Pronghorn & $\begin{array}{l}1976 \\
1977 \\
1978 \\
1979 \\
1980 \\
1981\end{array}$ & $\begin{array}{l}2 / 1 \\
21 \\
21 \\
21 \\
21 \\
21\end{array}$ & $\begin{array}{l}474 \\
499 \\
347 \\
240 \\
366 \\
470\end{array}$ & $\begin{array}{r}60 \\
65 \\
50 \\
7 \\
34 \\
106\end{array}$ & $\begin{array}{r}13 \\
13 \\
14 \\
3 \\
9 \\
22\end{array}$ & $\begin{array}{r}1,516 \\
1,297 \\
1,145 \\
816 \\
1,098 \\
1,833\end{array}$ \\
\hline
\end{tabular}

1/ Numbers given are point estimates projected from a sample of hunters contacted each year about their hunting activities.

2) Numbers of archery licenses issued apply to deer and antelope. 
Pronghorn are unique to North America, and occur naturally only in the western states and provinces; core habitat for pronghorn is sagebrush rangelands. Although they are now abundant, unregulated harvesting of pronghorn during the settling of the West, conversion of native rangelands to croplands, and intensive grazing by domestic livestock combined to reduce pronghorn populations; currently they total only about $4 \%$ of their presettlement numbers (Pyrah, in prep.). In continuous rangeland habjtats pronghorn would have little exposure to endrin applications. Pronghorn inhabiting rangeland interspersed with grainfields would have been susceptible to contact with endrin. Pronghorn occur on about $61,200 \mathrm{mi2}$, or $47 \%$ of the state (excluding national parks and Indian reservations). Land ownership of their range is $75 \%$ private, $18 \%$ public, and $7 \%$ state school lands.

Upland Game Birds. Four of Montana's 9 hunted upland gan e bird species occupy habitats which include grainfields, and therefore could come in contact with endrin.

Hungarian partridge, introduced into Montana in the early 1900's, currently have the widest distribution of any upland game bird in the state. They occur over some $94,700 \mathrm{mi}$, most of which is in private ownership. Partridge are extremely closely associated with grainfields; $95 \%$ of 1,448 partridge groups were observed within 1/4 mi of grain in Teton County, 1969-1974 (Weigand 1980). Because of their close relationship with farming, partridge are the upland game bird species most likely to encounter agricultural pesticides. The annual huriting harvest of partridge (1976-1980) averaged 81,800 birds (range, 46,400$103,900)$, with the lowest harvest in 24 years being recorded in 1981 (Table 2).

The ring-necked pheasant, introduced into Montana in the $1890^{\prime}$, is the most popular upland game bird in the state. It adapted to early agricultural practices, increased in numbers and expanded its range through the mid-1940's, and then declined statewide to a current range of about $17,300 \mathrm{mi}$. Most of the state's pheasant range is on private land. Pheasant hunting harvests averaged 99,800 per year (range, 87,800-106,500) between 1976 and 1980 ( Table 2).

Sharp-tailed grouse, a native species and Montana's second most popular upland game bird, inhabit about 83,000 mi2, or about $64 \%$ of the state. They live in prairie and foothill rangelands, and have adapted, within limits, to the encroachment of cultivated grains. A major portion of their range is in private ownership, although they also thrive on largetracts of public (Bureau of Land Management, BLM) land. Sharptails were considered the second most likely upland game bird species to contact endrin. Hunting harve of sharptails averaged 105,200 annualiy between 1976 and 380 (range, 75,200-137,300, Table 2 ); the 1981 harvest was the lowest since 1965 . 
Table 2. Annual harvests (rounded to the nearest 100) of four species of upland game birds in Montana, 1976-1981.

Native Species

Sharp-tailed Grouse

\section{Sage \\ Ring-necked} Grouse Pheasant
Introduced Species
Hung arian

Partridge

\begin{tabular}{rrrrr}
1976 & 137,300 & 50,800 & 87,800 & 103,900 \\
1977 & 95,200 & 34,700 & 102,300 & 103,900 \\
1978 & 96,300 & 43,600 & 102,200 & 93,000 \\
1979 & 121,800 & 66,400 & 106,500 & 62,100 \\
1980 & 75,200 & 34,600 & 100,100 & 46,400 \\
1981 & 56,000 & 26,700 & 98,900 & 29,900 \\
\hline
\end{tabular}

5-yr.Avg .

$(1976-1980)$

105,200

46,000

99,800

81,800

\% Change

1980 to 1981

$-23$

$-1$

$-36$

\% Change

Between 5-yr.

Average and

1981

$-42$

$-1$

$-63$

Sage grouse, another native species, are one of Montana's most unique game birds and the largest grouse species in North America. Like the pronghorn, sage grouse have evolved an almost inseparable alliance with sagebrush communities, a characteristic which makes sage grouse rather unadaptable to cultivated fields; sage grouse will feed on forbs in grainfields. The species inhabits about $50,000 \mathrm{mi}^{2}$ in Montana with large portions of its range in private and public [BLM and U.S. Forest Service (USFS)] ownership. The annual hunting harvest (1976-1980) averaged 46,000 birds (range, 34,600-66,400, Table 2); the 1981 harvest was the lowest in 23 years. Of the game birds considered here, sage grouse are probably the least likely to contact endrin.

Two additional Montana upland game bird species, the chukar partridge and Merriam's wild turkey, may frequent grainfields within their natural habitats. Neither species is native to Montana and based on their limited range in the state, were not considered to be at much risk of contacting endrin sprayed in 1981. Consequently, only 4 samples representing 3 turkeys were tested for endrin residues. 
Endrin uptake by these or other ground-dwelling bird species can be by several routes: (1) direct contact with the feet, scaley portions of the legs, and the skin around the eyes; (2) ingestion of contaminated vegetation, insects, and soil; and (3) preening of feathers.

Small mammals. Six of 10 furbearer and 5 of 6 predator species were likely candidates for exposure to endrin. The muskrat was the only furbearer tested for endrin residues; no predators were tested.

Forty-seven (64\%) of the 73 nongame mammal species in Montana are likely to contact agriculturally-applied endrin. These species are important as primary food sources for avian and mammalian predators, and could pass ingested endrin and its metabolites on to their predators. Species tested for endrin residues in the current studies were black-tailed prairie dog, cottontail rabbit, deer mouse, harvest mouse, house mouse, meadow vole, pocket mouse, porcupine, Richardson's ground squirrel, thirteen-lined ground squirrel, and white-tailed jackrabbit. Each of those species is primarily herbivorous, although several occasionally eat insects.

\section{Migratory}

Waterfowl. At least 28 species of waterfowl migrate through Montana, and 23 species are known to nest here (Table 3). Nineteen $(70 \%)$ of those species could have contacted endrin in Montana during migration, nesting, or brood rearing.

Nesting sites include many of the wetlands occurring in eastern Montana. An average of 118,100 wetlands occurred in the Central Flyway portion of Montana south of the Missouri River during 1974-1981 (Smith 1982). Those wetlands include natural prairie potholes and artificial reservoirs. Most reservoirs, constructed since the drought of the 1930's, were intended for use primarily by livestock; others were built as sources of irrigation water, to prevent local flooding, and/or to be used for warmwater fisheries. Rangelands adjacent to some reservoirs have been plowed, and are now cultivated for grain or hay crops. Treatment of those grain crops with endrin would likely result in contamination of the pond and its surrounding environment.

The prevailing dry conditions of 1980-1981 resulted in little or no water in many prairie wetlands. The 69,000 wetlands estimated for the Central Flyway portion of Montana south of the Missouri River in 1981 represents a $45 \%$ reduction from the 19741980 average, and a $65 \%$ reduction from the high $(195,100)$ recorded during this period (Smith 1982). Subsequently, breeding waterfowl either crowded onto existing water bodies for nesting, remained at traditional sites as nonbreeders, or left those areas to nest elsewhere. Because of the lack of restrictions on 


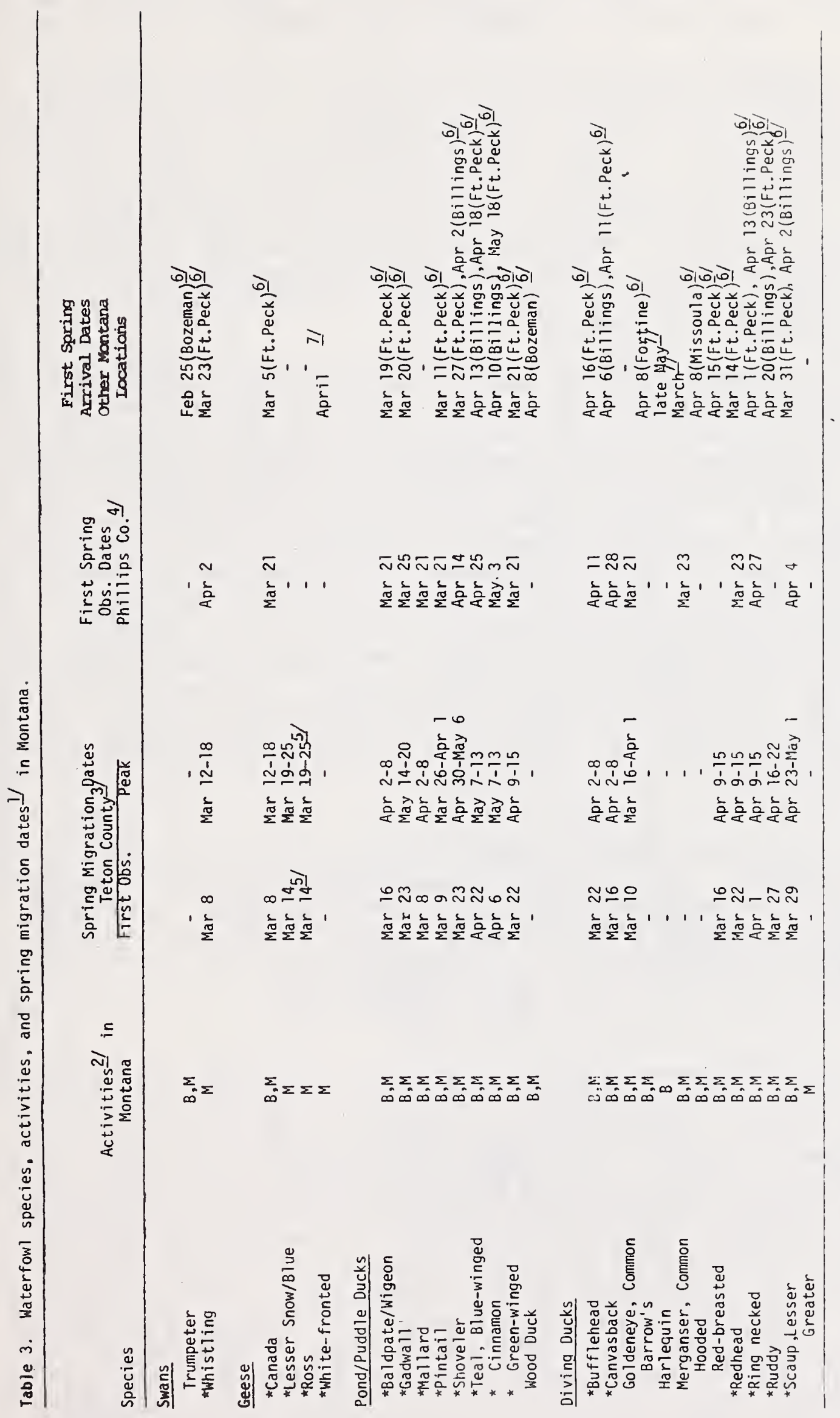

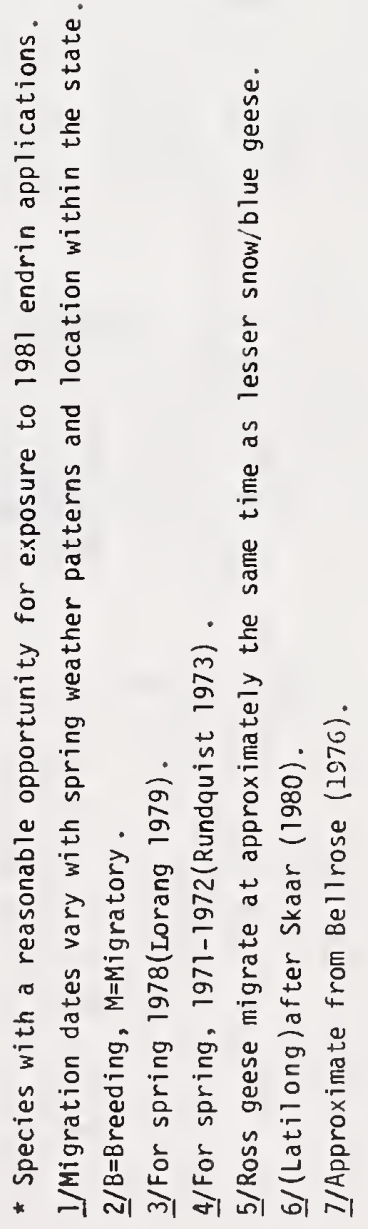


applying endrin on or near private wetlands, waterfowl remajning at those sites could have been exposed to 1981 endrin treatments.

Based on waterfowl breeding and production survey indexes, the U.S. Fish and Wildlife Service (FWS) estimated that Montana's 1981 fall flight would be $1.8 \mathrm{million}$ waterfowl, i.e. that many birds were resident and/or produced in Montana in 1981 (U.S. Fish and Wildlife Service 1981). Of that total, more than 1 million would migrate down the central Flyway and 0.35 million would travel down both the Pacific and Mississippi Flyways. Those figures do not include additional millions of waterfowl residing and produced in Canada and adjacent states which would migrate through Montana that fall.

The potential distribution of endrin-contaminated waterfowl available to hunters can be perceived from the direct recoveries of 3 species of waterfowl banded during the summer in Montana. Those data showed that $45 \%$ of Canada geese banded in Montana in summer were harvested by hunters the following fall in Montana (Fig. 1); $17 \%$ were taken in Colorado, 14\% in Idaho, and $8 \%$ in New Mexico. When all direct recoveries were considered, hunters in 13 states and 2 provinces in 2 flyways harvested Canada geese originating in Montana. Mallards banded in Montana were harvested in 32 states and 4 provinces and in all 4 flyways, with hunters in Montana, Nebraska, Idaho, Arkansas, and Colorado being the primary "beneficiaries" (Fig. 2). Pintails from Montana were taken in 29 states and 4 provinces and in all 4 flyways, with California, Texas, Montana, and Louisiana being the primary recipients (Fig. 3)。

other aquatic and migratory game birds. Species in this group which were tested, and which migrate through/to and breed in Montana include the common loon, coot, eared grebe, mourning dove, white pelican, and Wilson's snipe. Each species, except the loon, has widespread distribution in the state, and 3 species (coot, dove, snipe) are hunted and eaten by humans.

Raptors. Thirty-three species of hawks, owls, and eagles occur in the many diverse habitats in Montana. Nineteen of those are diurnal and 14 are nocturnal; 7 diurnal and 5 nocturnal species could contact endrin. The importance of raptors, as well as mammalian predators, is that they are generally at the peak of food chains, like humans. Persistent toxic environmental contaminants, like endrin, are passed from prey to predator with potentials for secondary poisoning, disrupted reproductive physiology, and aberrant behavior patterns of the predators. The present studies included testing of the golden eagle, great horned owl, harrier, kestrel, long-eared owl, and red-tailed hawk. Each of those species migrates rough and breeds and winters (except kestrels) in Montana. Eac: species also includes small mammals and/or birds in their diets. 


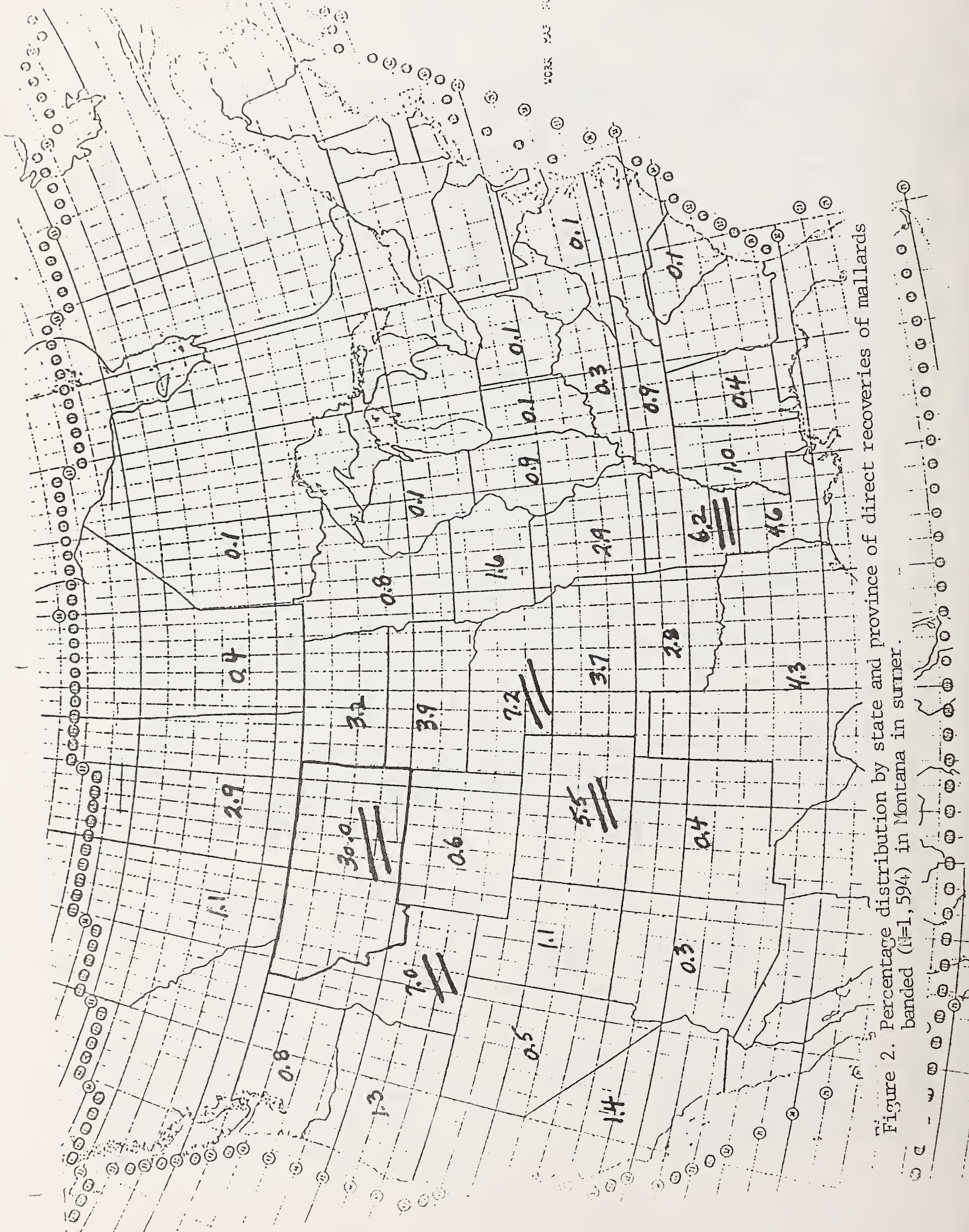


Passerines. This group includes 156 passerine and 40 shorebird species, the majority of which migrate through or to, breed in, and/or winter in Montana. Fifty-three (34\%) of the passerines and $14(35 \%)$ of the shorebirds had a reasonable charce of contacting endrin. Like small mammals, these birds are prey primarily for raptors, although mammalian predators will also eat them. Species included in the current studies which migrate through/to and breed in Montana are chestnut-collared longspur, cliff swallow, cowbird, horned lark, loggerhead shrike, McCown's longspur, meadowlark, red-winged blackbird, vesper sparrow, white-crowned sparrow, and yellow-rumped warbler. Species which migrate through/to and winter in Montana are the lapland longspur and snow bunting; horned larks also winter in Montana. These species represent a reasonable cross section of granivorous and insectivorous species in Montana farmlands.

Endangered Species. Three species classified as endangered by Montana Statute or the Federal Endangered Species Act could have been impacted by the 1981 endrin applications in the state.

Whooping cranes occur in Montana primarily as casual migrants. They belong to the main North American (i.e. the Aransas-Wood Buffalo) flock. The se cranes have been sighted in Montana during 6 spring and 2 fall migrations during 1968-1977 (D.L. Flath unpub. data). The principal spring migration period for Montana ( $45^{\circ}-49^{\circ} \mathrm{N}$. Lat.) is April 8-May 15; one report is from May 30. Their average length of stay in Montana is 2 days (range, 1-8 days).

While cranes are very marsh oriented, and eat semi-aquatic forms like frogs, tadpoles, snakes, and crabs, and aquátic vegetation, they do utilize upland habitat extensively during migration. In spring they are attracted to summer fallow, hay meadows, and grainfields where they feed heavily on adult and larval insects, small mammals, and waste grain.

Peregrine falcons also occur in Montana primarily as migrants, although they can be found here any time of the year. A minimum of 23 historic eyries are known for Montana. Attempts to reintroduce the species as nesters were initiated in 1981. Areas of principal occurrence include the east slope of the Rocky Mountains and the mountain ranges in the southern part of the state. The main observation period is October and November.

Peregrines are predatory, with other birds (mostly passerines, shorebirds, and waterfowl) being the main prey (Hickey 1969). Organochlorine insecticides are commonly credited with the decline of peregrines nationwide (Hickey 1969). The potential for assimilation of endrin by peregrines is high because they are at or near the top of their food chain. Mortality can result from acute exposure to endrin; chronic, sublethal levels can impact reproduction through failure of the adults to incubate eggs or to properly feed and care for young. 
Bald eagles are present in Montana year round. At least 40 breeding territories occur in the state, large numbers pass through during spring and fall migrations, and 450 or more overwinter here (D.L. Flath unpub. data). Five breeding territories are in southeastern Montana and 1 is along the east slope of the Rockies. The main spring migration period is February and March; nonbreeders may be encountered through April. Based on available data (Harmata 1982), the migration route in the east occurs between 2 gently converging lines bounded by the Bighorn and Powder Rivers in the south and the towns of Saco and Opheim in the North; Fort Peck Reservoir and the C.M. Russell National Wildlife Refuge are included in their entirety.

These eagles feed primarily on fish, and will concentrate in large numbers where dead, dying or otherwise vulnerable fish are available (eg. southwest side of Glacier National Park in fall). Foods of secondary importance are dead or "crippled" ducks, rabbits, and other mammals; mammals may be eaten in the form of carrion.

Miscellaneous Samples

Samples included here are not readily assignable to another group. Sediment was tested to document persistence of endrin in aquatic habitats. All other samples (2 each of barley, wheat, cutworms, and snapping turtle fat, and 1 of snails) are additional potential sources of endrin contamination for wildlife and/or for humans.

\section{Agriculture}

Agriculture is Montana's primary economic industry. Farms and ranches occupy 62 million of the state's 93 million acres of land, resulting in Montana's ranking as the second largest agricultural state in the nation (Montana Crop and Livestock Reporting Service 1982). Although numbers of farms in 1980 $(23,800)$ had decreased $36 \%$ since 1950 (37,200), the size of each farm increased by $49 \%$ during the same period. Improved farming technology, including the use of pesticides, has contributed to increased farming efficiency.

A total of 7.66 million acres was seeded to small grains in Montana in 1981 (Montana Crop and Livestock Reporting Service 1982). Wheat comprised $77 \%$ (6.04 million) of that acreage and winter wheat was $45 \%$ ( $2.7 \mathrm{million}$ ) of the total wheat acreage. The distribution of winter and spring wheat production by county is illustrated in Fig. 4. 
Figure 4. Distribution of winter and spring wheat by county in Montana, 1979 (Iontana Agricultural Statistics 1980:34).

WINTER WHEAT

1979 Production

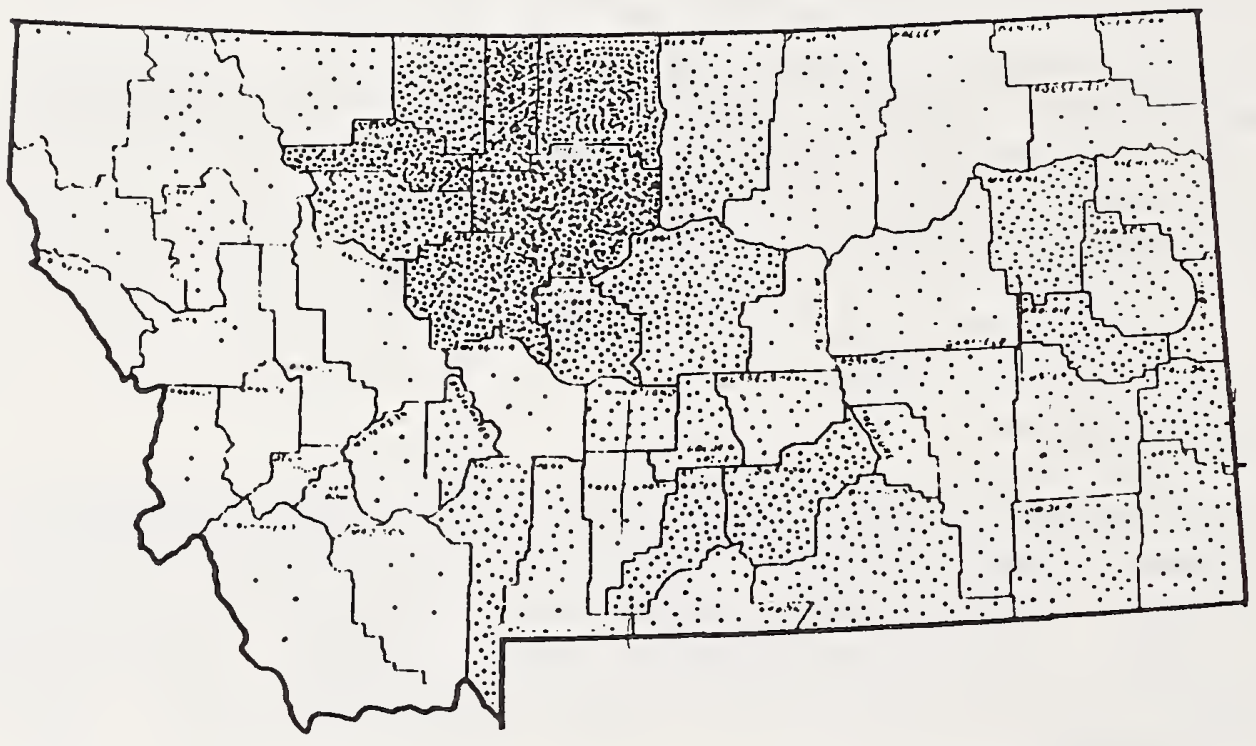

$1 \mathrm{dot}=20,000$ Bushels

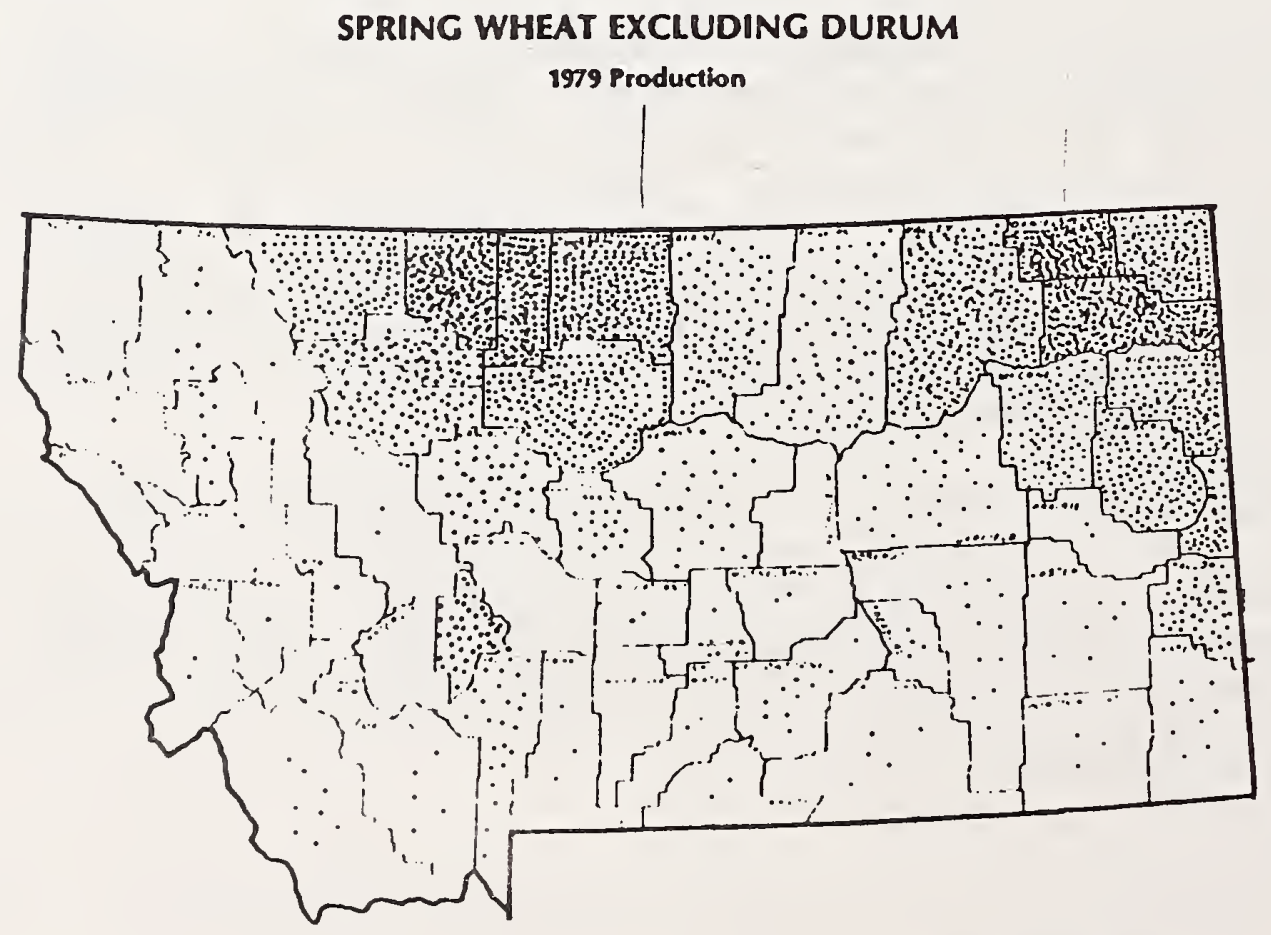

1 dot $=20.000$ Bushels 


\section{Cutworms}

Two species of economically damaging cutworms (Family Noctuidae, Order Lepidoptera) occur in Montana: the army cutworm, Euxoa auxiliaris (Grote) and the pale western cutworm, Agrostis orthogonia Morrison. Both species inhabit dryland areas (ranges and cultivated crops), produce 1 generation per year, and rarely reach local densities sufficient to cause severe economic losses to grain during 2 consecutive years. Conditions that promote good survival and high spring populations are a dry July followed by a wet fall. Their remaining biological characteris tics are quite different, which in turn affects the effectiveness of various control methods.

Army cutworms overwinter as larvae and pupate during late April-early May. Adults are active for a brief period following emergence and then aestivate until fall, when they again emerge, mate, and lay eggs. Eggs are laid in loose soil and hatch in about 10 days. Larvae are active, nocturnal surface feeders.

Pale western cutworms overwinter as eggs, hatch in late spring and then burrow even deeper into the soil. Further larval development and pupation occurs underground. Adults emerge in late september, mate, and lay eggs; again, loose soil is preferred for egg deposition. The larvae are primarily subterranean feeders.

There have been 38 "economic infestations" of army cutworms in Montana during 1903-1982 and 30 of pale western cutworms, 1915-1982 (O.G. Bain pers. comm.). Apparently every county east of the Continental Divide (except Daniels, Garfield, and Meagher) has experienced such an outbreak of army cutworms (Fig. 5 ); 6 counties west of the Divide have also been impacted. Similarly, heavy occurrences of pale western cutworms have appeared in most eastern Montana counties (Fig. 6).

The occurrence of army cutworms in 1981 was officially confirmed by MDA entomologist O.G. Bain, about 11 March. The species was found in winter wheat, alfalfa, pasture, and native rangeland in southeastern and southcentral Montana. Pale western cutworms were later identified in southcentral and northcentral Montana. Because of the value of grain crops, extensive cutworm reduction efforts, primarily using endrin, began by 1 March; most endrin was applied by 20 April. Early projections from the MDA indicated that as many as 275,000 acres of grain would be treated with endrin ( $S$. Baril pers. comm.). Pesticide dealer sales records later suggested that the total acreage treated with all chemicals in 1981 approximated 200,000 acres; a minimum of 98,848-123,560 acres were treated with endrin. The number of additional acres treated with endrin stored on farms and used during 1981 remains unknown. 


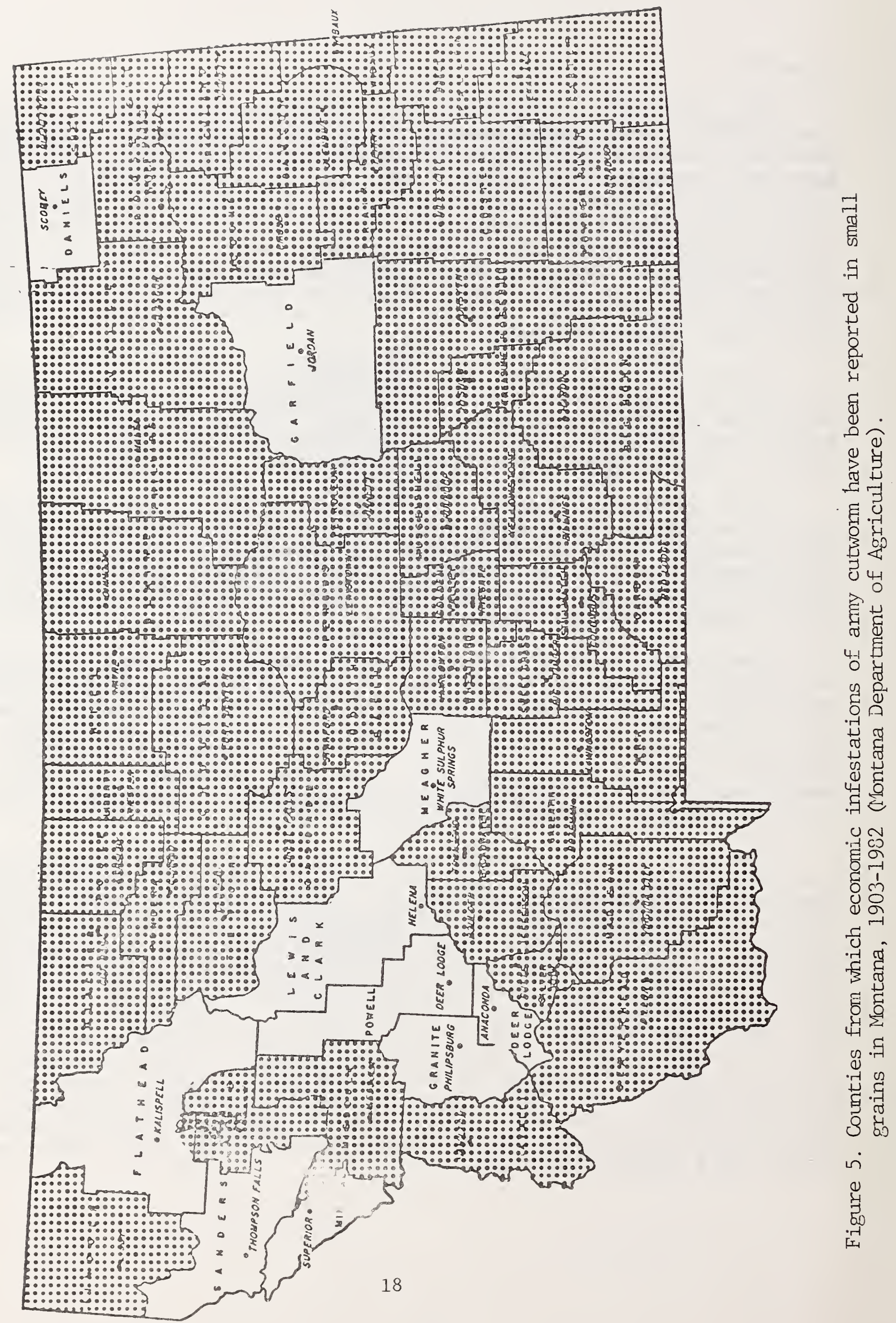




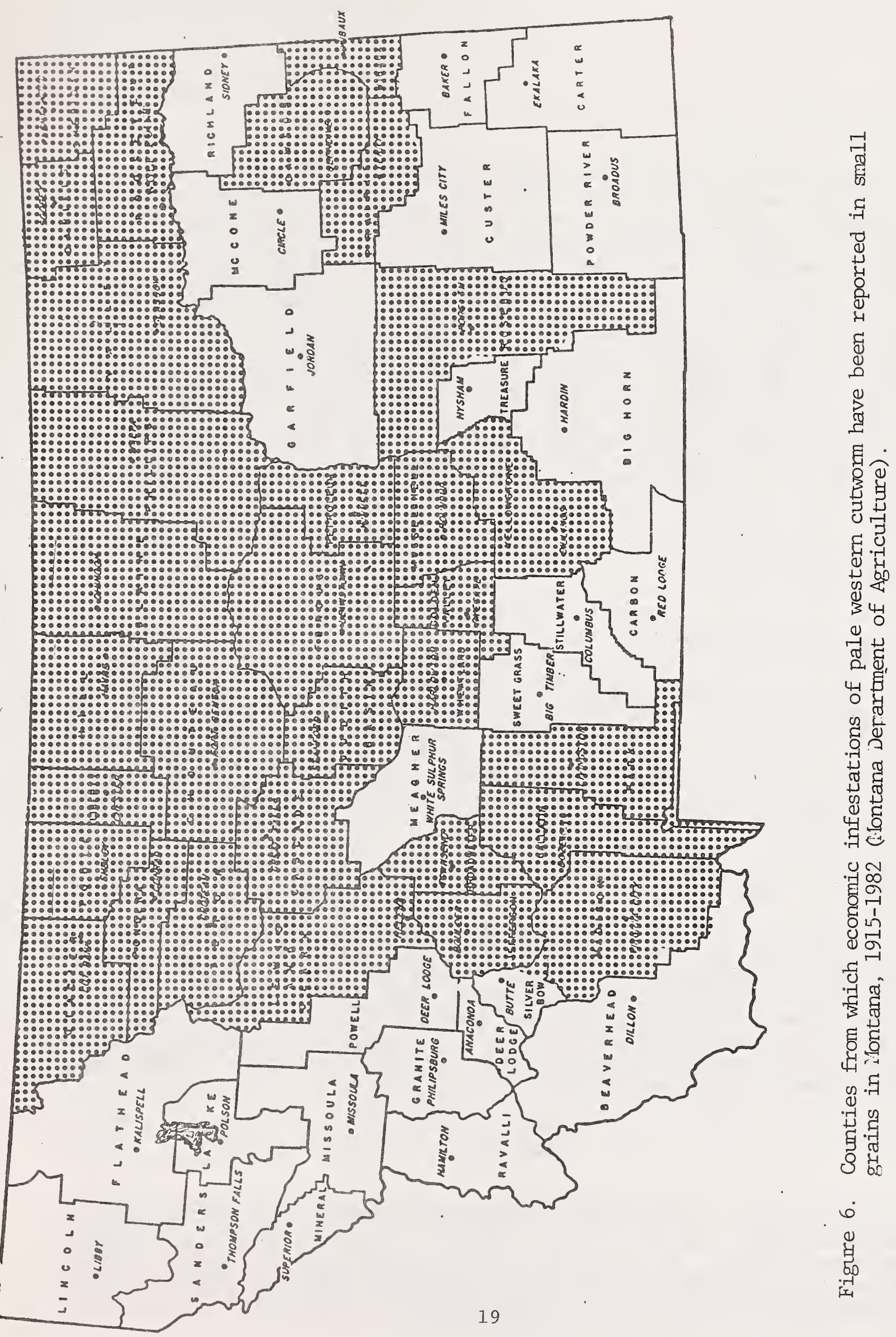


The first settlers to break Montana's prairie sod to cultivate grain at the turn of the 19th Century had few chemical weapons for combating outbreaks of cutworm (Cooley and Parker 1916). A poisoned bran mash, using Paris green (copper acetoarsenite), scattered over greening fields in spring or placed in furrows in those fields was one of the first cutworm treatments. Toxaphene and dieldrin, 2 other chlorinated hydrocarbon insecticides, came into widespread use on Montana crop and range lands in the early 1950's; dieldrin was especially effective on pale western cutworms. Toxaphene performed erratically under cool spring conditions, so when endrin (persistent and effective in a variety of weather conditions) was introduced in 1954 it almost immediately became the cutworm insecticide of choice. Endrin remained the preferred cutworm insecticide through 1981 (Montana Department of Agriculture 1981), and endrin is the only insecticide registered by EPA to combat pale western cutworms. Because of the efficacy of the other 2 compounds, endrin probably had limited use for rangeland grasshopper control.

\section{Pesticide Registration}

Endrin was registered for cutworm and grasshopper control in cereal grains in the Great Plains by the USDA in 1951. It has been recommended for control of cutworms ir cereal grains in Montana since 1954 by the Montana Cooperative Extension Service (Montana Insect Pests, 1953-1954). Because of its hazard to wildlife and the environment, the use of endrin on agricultural crops east of the Mississippi River was banned by the U.S. Environmental Protection Agency (EPA) in 1979; it continued to be registered for use in grainfields in western states (Federal Register 1979).

Montana statutes require state registration of any pesticide registered by the EPA [Sec. 80-8-201(3), MCA] and distributed, sold, or transported in Montana. State registration may be more restrictive than EPA's, up to and including cancellation. Label restrictions by both the EPA and MDA do not permit aerial application of endrin within $0.25 \mathrm{mi}$, or ground application within $0.125 \mathrm{mi}$, of public waters; no such protection zone is afforded private ponds or reservoirs.

\section{End $r$ in}

Endrin is a chlorinated hydrocarbon compound which has been used extensively in the United States as an avicide, insecticide, and rodenticide. It is sold as a technical grade product, containing not less than 92\% active ingredient (Brooks 1974a); field formulations contain 19.5 or $19.7 \%$ active ingredient. Its use as 
a pesticide began in 1951 and increased throughout the 1950's and $1960^{\prime} \mathrm{s}$.

Endrin and other similar pesticides apparently enter aquatic systems directly as drift, or indirectly on suspended material in runoff. Much of this suspended material is organic matter, and when filtered out of the water may show residue levels 10,000 to 20,000 times as great as in the filtrate (Keith 1966). In environments with invertebrates, they appear to incorporate residues from organic matter into food chains; high residues are not deposited with sediments on pond bottoms. Where no invertebrates are present, residues remain in suspended material and are deposited in sediments or on aquatic plants (Keith 1966). Thus, organic materials and invertebrates are important factors in determining the fate and involvement of insecticides in aquatic environments. Animals utilizing aquatic invertebrates, or submerged vegetation in environments having few invertebrates, might be seriously exposed to insecticides in the diet.

Metabolites

Under the influence of sunlight, endrin applied to plants converts to a half-cage ketone (Korte 1972:4-5). However, at the time of that study, neither compound had been detected in the atmosphere. Although Korte isolated a $\Delta$-keto-endrin in crystalline form from the surface of cotton plants grown in the greenhouse, he also found that $96 \%$ of endrin-C 14 had evaporated or been transpired by the plants. He concluded that the largest amounts of pesticide generally did not remain in plants and soil, but were introduced into the atmosphere. Conversely, Menzie (1974:22) found that 33\% of radio-activated endrin applied to upper leaf surfaces of cotton plants remained 12 weeks after application.

Translocation of endrin, and/or its metabolites, into plants has been documented. Korte (1972:10-18) reported that very little radio-activated endrin was absorbed through the plant cuticulum, but that large amounts were found in the soil, very little was in the roots, and large amounts occurred in the plant stalks. He also found that the main portion of keto-endrin is very hydrophilic and concentration of this metabolite was highest in the stalks and leaves. Menzie (1974) revealed that $26 \%$ of radioactive endrin applied to upper leaf surfaces was found on and in the leaves, and about $41 \%$ occurred in other plant parts and in the soil; at least 5 products plus unchanged endrin were found. Harris and Sans (1969, in Egan 1972:149) reported that beets, carrots, potatoes, corn, oats, and alfalfa can derive endrin from soils.

In mammals, metabolism of endrin apparently differs between species. Korte (1972:10-11) found rabbits given radio-activated endrin excreted 4 endrin metabolites, 3 of which contained hydroxy groups but only one of which was considered to be hydrophilic. None of those metabolites were structured the same as 
$\Delta$-keto-endrin, an endrin metabolite of plants. In rats, however, Korte (1972:10-11) found that radio-activated endrin was metabolized to one hydrophilic metabolite. Later, Menzie (1974:21) reported that rats metabolized endrin to at least 3 compounds; keto-endrin (in tissues and urine) and 2 monohydroxylated endrin analogs (in feces). Stickel et al. (1979a) stated that "the important and highly toxic metabolite 12-keto-endrin" had been found in rodents but not in birds. Bedford et al. (1975a) reported that 12-keto-endrin was 5 times more toxic than endrin to rats, and that $0.3 \mathrm{ppm}$ in the brain was lethal.

Although Korte (1972:11) was able to demonstrate the formation of 1 hydrophilic endrin metabolite in the liver of rats, he could not identify it by mass spectrum or gas chromatogrambecause it decomposed above temperatures in the 120-140 ${ }^{\circ} \mathrm{C}$ range. Apparently part of this procedural problem has been overcome, and at least one endrin metabolite can now be quantified from animal flesh (K. Kissler pers.comm.). In summary, it is apparent that endrin is metabolized better by animals than by plants.

Persistence in Soil

Wildife is exposed directly to endrin at the time of its application, but also indirectly for months later via endrin and its metabolites in soils and plants. Studies (reported in Pimentel 1971:44) have shown that endrin persists in soils for extended periods of time, although at reduced concentrations. Nash and Woolson (1967) found that endrin applied at 25 ppm to soil persisted at $50 \%$ of its applied rate for 12 years; in sandy loam soil, $41 \%$ of endrin applied at 100 ppm remained 14 years later. Persistence in Montana soils may vary from that reported in these studies.

\section{Wildife Management Concerns}

The ensuing discussion points out the reasons for the concern expressed for wildlife when it became known that endrin was being extensively used in Montana in 1981.

According to Carson (1962:27), "It [endrin] is 15 times as poisonous as DDT to mammals, 30 times as poisonous to fish, and about 300 times as poisonous to some birds." Because of its high acute toxicity to a wide variety of invertebrates and vertebrates, and its persistence in the environment, the use of endrin subsided especially after its registration for use in cotton fields in the south was cancelled (Environmental Protection Agency 1978:133). Nonetheless, an estimated 400,000 pounds were produced in 1978 .

A recent EPA draft report (Environmental Protection Agency 1980b) summarized 115 incidents involving endrin (45) or endrin in association with other pesticides (70) during a 15-year 
period, 1966-1980. Sixty-two of the cases dealt with fish (38 species involved), 21 with humans, 17 with domestic animals, 10 with the general environment, and 5 with wildlife (23 species). A majority of the incidents ( 84 of the 115) were associated with agricultural uses of endrin. Only 1 of 28 endrin-only and 1 of 56 endrin plus other pesticides incidents were attributed to misuse of the compounds. This report advises that although not all cases were confirmed as to whether or not pesticides were involved, the absence of confirmation should not be interpreted that they were not involved.

This single report suggests strongly that endrin is indeed hazardous to a broad spectrum of vertebrates, including humans. The low incidence of documented misuse of endrin further suggests that most endrin-related problems are attributable to its ordinary use.

\section{Aquatic}

Endrin is extremely toxic in very low quantities to aquatic organisms. Endrin gained public recognition in the United States when it was identified as the toxic agent responsible for massive fish kills along the Atchafalaya and Mississippi Rivers in the late 1950's and early 1960's (Graham 1970:97-102, Rowe et al. 1971). Endrin is considerably more toxic to fish than 3 other chlorinated hydrocarbon insecticides used commonly in Montana ( $\mathrm{Table} 4$ ).

Table 4. Median tolerance limits to fish, and application rate necessary to reach those levels, of four chlorinated hydrocarbon insecticides (from Rudd 1964:105) currently used in Montana.

$\begin{array}{ccl}96-h r \text { TLm1/ } & \text { Ounces per acre applied to } \\ \text { Insecticide } & \text { (parts per } & \text { surface of water } 3 \text { ft deep to } \\ \text { bilion) } & \text { reach TLm concentration }\end{array}$

$\begin{array}{lrl}\text { Endrin } & 0.6 & 0.0003 \\ \text { Toxaphene } & 3.5 & 0.002 \\ \text { Heptachlor } & 19.0 & 0.01 \\ \text { Lindane } & 77.0 & 0.04\end{array}$

$1 /$ Median tolerance level. 
The acute toxicity of endrin to fish varies through a relatively narrow range (Table 5). Generally less than $1 \mathrm{ug} / 1$ is sufficient to result in mortality of $50 \%$ of a fish population under laboratory conditions. Test results also suggest that coldwater fish species tend to be more sensitive to endrin poisoning than warmwater species.

Endrin appears to be less toxic to aquatic invertebrates than it is to fish (Table 6). However, stoneflies (Order Plecoptera), an important food item for trout in Montana, seem to be particularly sensitive to endrin poisoning.

Fish absorb endrin directly from their environment as well as from eating endrin-contaminated foods. Bioconcentration of endrin in fish is quite rapid (Jarvinen and Tyo 1978), and concurrent appearance of endrin metabolites in their tissues indicates endrin degradation within fish. Endrin bioconcentration factors (the ratio of endrin in fish tissues to that in water) for fathead minnows are 10,000 at 47 days (Mount and Putnicki 1966) and 7,000 after 300 days (Jarvinen and Tyo 1978). Similar factors for channel catfish are 2,000 at 41 days and 1,640 after 44 days (Argyle et al. 1973). From this it appears that endrin metabolism and excretion varies widely among fish species.

Bioconcentration of endrin also occurs in aquatic plants. Four species of algae exposed to 1 ppm of endrin for 7 days under test conditions exhibited bioconcentration factors of 140-220, depending on the species (Vance and Drummond 1969, in Environmental Protection Agency 1980a:B-29).

\section{Terrestrial}

Endrin was the second most acutely toxic (orally) of 131 pesticides tested on young bobwhites (Colinus virginianus), Japanese quail (Coturnix c. japonica), ring-necked pheasants, and mallards (Harris and Eschmeyer 1976:26); it was the most toxic of the organochlorine compounds tested. Acute oral toxicities of endrin to some bird and mammal species are listed in Table 7 .

Endrin acts largely on the central nervous system of vertebrates, although Hinshaw et al. (1966) also reported left ventricular failure in dogs intravenously injected with endrin at a dosage that resulted in approximately $75 \%$ mortality.

Organochlorine pesticides are rapidly assimilated by both birds and mammals, with residue levels in all tissues increasing rapidly at the beginning of feeding trials, then gradually approaching a plateau level representing an equilibrium between intake and storage and excretion (Cummings et al. 1966, 1967; Stickel 1973).

The most rigorous criteria for diagnosis of death due to organochlorine pesticide poisoning is the residue concentration in the brain; these are generally similar for a given chemical 
Table 5. Acute toxicity of endrin to 12 species of fish which occur in Montana.

\begin{tabular}{|c|c|c|}
\hline Species & $\begin{array}{l}\text { Stage } 1 / \text { or } \\
\text { Wt. (gm) }\end{array}$ & $\begin{array}{c}\text { Water } \\
\text { Temp. }\left({ }^{\circ} \mathrm{C}\right)\end{array}$ \\
\hline
\end{tabular}

Black bullhead Ictalurus melas

Bluegill

Lepomis macrochirus

Brook trout

Salvelinus fontinalis

Carp

Cyprinus carpio

Channel Catfish

Ictalurus punctatus

Coho salmon

Oncorhynchus kisutch

Cutthroat trout

Salmo clarki

Fathead minnow

Pimephales promelas

Largemouth bass

Micropterus salmoides

Mosquitofish

Gambusia affinis

Rainbow trout

Salmo gairdneri

Yellow Perch

Perca flavescens

\begin{tabular}{|c|c|c|}
\hline 1.5 & 24 & $1.1(1.0-1.3)^{3 /}$ \\
\hline $\begin{array}{l}1.5 \\
-\end{array}$ & $\begin{array}{l}18 \\
24 \\
--\end{array}$ & $\begin{array}{l}0.61 /(0.50-0.74)^{3 /} \\
0.34 / \\
0.37-0.615 /\end{array}$ \\
\hline - & - & $0.355-0.596 /$ \\
\hline $\mathrm{F}$ & 12 & $0.32(0.25-0.41)^{3 /}$ \\
\hline 1.4 & $\begin{array}{l}24 \\
--\end{array}$ & $\begin{array}{l}0.32 /(0.29-0.35)^{3 /} \\
1.04 /\end{array}$ \\
\hline - & -- & $\begin{array}{l}0.274 / \\
0.761 /\end{array}$ \\
\hline- & -- & $0.113-0.1926 /$ \\
\hline $\begin{array}{l}1.2 \\
-\end{array}$ & $\begin{array}{l}18 \\
--\end{array}$ & $\begin{array}{l}1.8(1.0-33.0)^{3 /} \\
0.40-0.498\end{array}$ \\
\hline 2.5 & 18 & $0.31(0.25-0.39)^{3 /}$ \\
\hline 0.6 & $\begin{array}{l}17 \\
--\end{array}$ & $\begin{array}{l}1.1 \\
0.75 \\
(0.4-3.4) I /\end{array}$ \\
\hline
\end{tabular}

1.0

13

13

$0.75,(0.64-0.88)^{3 /}$
0.54

-
12

0.405 /

F
$0.15(0.12-0.18)^{3 /}$

1/ $F=$ Fingerling

2 Lethal (or effective) concentration in water which results in 50\% mortality, expressed as micrograms/liter.

$3 /$ Johnson and Finley (1980)

4/ Cope (1965)

5/ Macek et al. (1969)

6/ Post and Schroeder (1971)

7/ Katz and Chadwick (1961)

8/ Brungs and Bailey (1966, in Environmental Protection Agency 1980a) 
Table 6. Acute toxicity of endrin to 10 kinds of aquatic invertebrates $1 /$ which occur in Montana.

\begin{tabular}{|c|c|c|}
\hline Spec & Stage $\mathrm{e}^{2 /}$ & $\begin{array}{c}\text { Water } \\
\text { Temp. }\left({ }^{\circ} \mathrm{C}\right)\end{array}$ \\
\hline
\end{tabular}

Cranefly

Tipula sp.

\section{Crayfish}

Orconectes nais

Palaemonetes kadiakensis

Daphnids

Daphnia magna

Daphnia pulex

Simocephalus sp.

J

15

$I_{M}$

21

21

21

15

21

Dragonfly

Ischnura venticalis $\mathrm{J}$

Mayflies

Baetis sp.

Hexagenia bilineata $I_{1}$

Scuds

Garmarus lacustris M

Garmarus fasciatus M

Seed Shrimp

Cypridopsis vidua M

Sowbug

Asellus brevicaudus M

Snipefly

Atherix variegata J

Stoneflies

Acroneuria sp.

Claassenia sabulosa

Pteronarcella badia

Pteronarcys califormica
$\mathrm{YC}_{2}$
$\mathrm{YC}_{2}$
$\mathrm{~N}^{2}$

$\mathrm{YC}_{2}$
15

15

15

21

21

21

15

15

15

15

15

15
$12(7 \cdot 3-18)$

$3.2 \frac{3 /}{3.2}(1.6-7 \cdot 5)$

4.241
20 II $^{\prime}(13-30)$
45 ㄴ $(35-58)$

$2.4(1.5-3.8)$

$0.90(0.57-1.4)$

$62(41-95)$

$3.0(2.0-4 \cdot 5)$

$4.3(3.5-5.2)$

1.841

$1.5(0.9-3.7)$

$4.6(3.1-6.8)$

$>0.18$

$0.08(0.06-0.09)$

$0.54(0.40-0.72)$

$0.25(0.20-0.31)$

$1 /$ Johnson and Finley (1980)

2) J =Juvenile, $I_{1}=$ first instar, $I_{E}=e a r l y$ instar, M=mature, $\mathrm{N}=$ naiad, $\mathrm{YC}_{2}=$ second year class

$3 /$ Tested in hard water, $272 \mathrm{ppm}$ as $\mathrm{CaCO}_{3}$

4/ 48-hr $\mathrm{EC}_{50}$ (i.e. effective concentration) 
Table 7. Acute oral toxicity of endrin to birds and mammals.

Species Sex Age Sample Purity $\begin{aligned} & \text { Toxicity, or } \\ & L D_{50}(\mathrm{mg} / \mathrm{kg})\end{aligned}$ References

Birds:

\begin{tabular}{|c|c|c|c|c|c|}
\hline $\begin{array}{l}\text { Sharp-tailed } \\
\text { Grouse }\end{array}$ & F & $4 \mathrm{yr}$ & $96 \%$ technical & $0.75-1.50$ & $\begin{array}{l}\text { Tucker and Crabtree } \\
\text { 1970:59 }\end{array}$ \\
\hline Pigeon & $M \& F$ & - & $96 \%$ technical & $2.0-5.0$ & Tucker and Crabtree \\
\hline Pheasant & F & $3-4 \mathrm{mo}$ & $97 \%$ technical & $\begin{array}{l}1.78 \\
(1.12-2.38)\end{array}$ & Tucker and Crabtree \\
\hline Mallard & F & $10-13 \mathrm{mo}$ & $96 \%$ technical & $\begin{array}{l}5.64 \\
(2.71-11.7)\end{array}$ & Tucker and Crabtree \\
\hline \multicolumn{6}{|l|}{ Mamma ls: } \\
\hline Rabbit & - & -- & -- & 5.10 & Pimentel 1971:52 \\
\hline Mule Deer & - & $10 \mathrm{mo}$ & - & $6.25-12.5$ & $\begin{array}{l}\text { Tucker and Crabtree } \\
\text { (unpublished) }\end{array}$ \\
\hline Rat & - & - & -- & 10 & Rudd 1964:20 \\
\hline Guinea Pig & - & - & -- & $10-36$ & $\begin{array}{l}\text { Negherbon } 1959 \text { (in } \\
\text { Pimentel 1971:42) }\end{array}$ \\
\hline Domestic Goat & $F$ & $12-24 \mathrm{mo}$ & $96 \%$ technical & $25-50$ & $\begin{array}{l}\text { Tucker and Crabtree } \\
\text { 1970:59 }\end{array}$ \\
\hline
\end{tabular}

across a wide range of bird and mammal species (Stickel 1973). Among specimens found dead, $0.8 \mathrm{ppm}$ or more of endrin in the brain is diagnostic of death due to endrin poisoning, while 0.6 ppm or less generally indicates death from other causes. The intervening zone is one in which both victims and survivors might occur (Stickel et al. 1979a). Recent findings (Heinz and Johnson 1981) suggest that these criteria do not apply to collections of live specimens. They demonstrated that dieldrin, and probably endrin and all other persistent organochlorines, caused birds to enter into an irreversible starvation process at brain residue levels averaging only half of the lethal concentration, and as low as $10-15 \%$ for highly sensitive individuals. The birds ceased eating at clearly sublethal brain residue levels, but in the process of weight loss, continued to mobilize the chemical to the brain until lethal levels were reached. Thus, collected specimens exhibiting no symptoms of poisoning and having sublethal brain residues could actually be doomed. 
Many cases of direct mortality of wildlife following field applications of endrin are documented. The EPA listed 5 incidents involving endrin (or endrin associated with other pesticides) and wildlife in the U.S. during 1966-1980 (Environmental Protection Agency 1980b). Mortalities of mamnals jncluded pronghorn, deer (Odocoileus spp), opossum (Didelphis virginiana), rabbit (sp. unk.), raccoon (Procyon lotor), and skunk (Mephitis spp). Affected bird species included the bald eagle, blackcrowned night heron (Nycticorax nycticorax), great blue heron (Ardea herodias), cattle egret (Bubulcus ibis), great egret (Casmerodius albus), snowy egret (Leucophoyx thula), brown pelican (Pelecanus occidentalis), wild turkey (Meleagris spp), bobwhite, dove, Canada goose, bluebird (Sialia spp), blue jay (Cyanocitta cristata), mockingbird (Mimus polyglotta), cardinal (Richmondena cardinalis), white-throated sparrow (Zonotrichia albicollis), and other sparrows.

In a study of the effects of endrin applied to colorado wheat fields for pale western cutworm control, McEwen et al. (1972) reported no significant differences in numbers of birds ( 49 species) between treated and untreated fields during the first 12-14 days posttreatment. However, during the 2-7 week posttreatment period there was a significant $(P<0.01)$ reduction in numbers of resident birds associated with treated fields; the decrease was attributed to direct mortality and emigration. Four species of mammals also died by direct endrin poisoning; jackrabbits were particularly sensitive.

Hunt and Keith (1962) reported that endrin applied to potato fields at 9 ounces per acre resulted in the deaths of 20 pheasant hens and 12 chicks. They also reported that 7 valley quail (Lophortyx californicus) were found dead in berry fields sprayed with 0.3 pounds of endrin per acre. Endrin applied at 0.8 pound per acre for meadow mouse control in dormant alfalfa resulted in the deaths of 5 cackling geese (Branta canadensis minima), a pheasant, a long-eared owl, and a killdeer (Charadrius vociferus) (Keith 1963:52). Subsequently, 8 cackling geese, 7 pintails, and 7 wigeon were placed in cages in a treated field; within a week, 4 geese, 2 pintails, and 1 wigeon had died. All cackling geese, white-fronted geese, and wigeon experimentally force-fed $5 \mathrm{mg} / \mathrm{kg}$ endrin died within 3 hours; all those force-fed $2.5 \mathrm{mg} / \mathrm{kg}$ survived a 9-10 hr observation period.

Endrin applied to wheat for cutworm control, at the same rate recommended for similar use in Montana, has resulted in poisoning deathis of both mule and white-tailed deer, pronghorn, and cattle (Anonymous 1968, Colorado Department of Agriculture 1968, Hepworth and Roby 1968, Environmental Protection Agency $1980 \mathrm{~b})$.

Although direct riortility of wildlife is a sometimes obvious result of pesticide use, pesticide-induced population changes of an ecologically significant nature can occur in the absence of direct poisoning. Such changes may often go undetected; if detected, the causes for such changes may not even be suspected. 
Pesticide related causes for such changes could include reproductive impairment, increased neonatal mortality, ard physiological or behavioral changes that can affect survival. All of these effects have been documented among birds and/or mammals experimentally administered endrin.

Endrin-caused reproductive impairment and increased neonatal mortality have been reported by many workers. Pheasants were given endrin at dietary concentrations of $0.5,1,2$, or 10 ppm during the reproductive period (Dewitt 1956), and hatchability and survival of young hatched from eggs of hens at each level were determined. All test birds receiving $10 \mathrm{ppm} d i e d ;$ no mortality occurred among the other groups of birds. Eggs produced by hens at both the 10 and 2 ppm levels showed reduced hatchability, and chicks hatched from eggs of hens receiving 10 ppm suffered significantly higher mortality than controls (62\% vs $5 \%$ ) in their first 2 weeks of 1 ife. The latter result is somewhat academic since those hens would not have survived long enough to have raised young. However, there may be field situations where a level between 2 and $10 \mathrm{ppm}$, or a gradually decreasing level, on vegetation is survived by some adults which are nonetheless unable to raise young to independence.

Groups of quail receiving $1.0 \mathrm{ppm}$ of endrin in their diet during either the winter or reproductive period each suffered $25 \%$ mortality (vs $6.25 \%$ for controls), and chicks from both groups had significantly lower survival than controls (DeWitt 1956). Quail dosed during only the winter period also produced fewer eggs, the hatchability of which was less than those of controls $(70 \%$ vs $84 \%)$. There were no differences in these parameters between controls and birds dosed only during the reproductive period. Quail receiving $1.0 \mathrm{ppm}$ of endrin in the diet during both the winter and reproductive season experienced $60 \%$ mortality, and no eggs were obtained from those birds (DeWitt 1956).

Endrin residue levels in eggs which result in impaired reproduction are reported to be approximately $0.3 \mathrm{ppm}$ and above for the screech owl (Fleming et al. 1982), and approximately 0.5 ppm or more for the brown pelican (Blus 1982). The screech owls of Fleming et al. (1982) received $0.75 \mathrm{ppm}$ of endrin in the diet, and residues in eggs ranged from 0.12 to $0.46 \mathrm{ppm}$, with the first egg being laid between 25 and 55 days after birds were started on treated food. Eggs of domestic chickens receiving 0.25 ppm of endrin in the diet for 8 weeks contained endrin residues of $0.2-$ $0.31 \mathrm{ppm}$, while eggs of hens receiving $0.75 \mathrm{ppm}$ in the diet contained $0.3-0.36 \mathrm{ppm}$. Eggs still contained $42-47 \%$ of these levels 4 weeks after hens were returned to endrin-free diets (Terriere et al. 1959). Clearly, dietary levels of 1 ppm or less of endrincan result in residue levels in eggs which may result in reduced reproduction.

Among mammals, significant parental mortality of deer mice occurred at dietary levels of $2 \mathrm{ppm}$ of endrin or more; parents surviving concentrations of 4 ppm or more weaned significantly 
fewer young (Morris 1968). Endrin at dietary levels of 5 ppm for 120 days, beginning 30 days before mating, resulted in significant parental mortality and smaller litters among laboratory mice (Good and Ware 1969). Groups of pregnant female hamsters and mice given single oral doses of endrin (1/2 the LD50) on day 7 , 8 , or 9 of pregnancy produced significantly greater numbers of young with birth defects than did controls (0ttolenghi et al. 1974). Fetal mortality was also higher among treated groups of both species, but the results were significant only for the hamsters.

Snyder (1963, in Hathway and Amoroso 1972:2.28) reported significant reductions in numbers of litters produced by meadow voles 2 months after endrin was applied at $0.6-2.0$ pounds per acre to bluegrass neadows.

Numbers of meadow voles declined significantly following application of $0.5 \mathrm{lb} / \mathrm{A}$ of endrin to an experimental grassland plot (Morris 1970). Invasion of new individuals, which survived well, allowed rapid population recovery. However, deer mouse populations declined abruptly following application, and did not recover during the next 2 years.

Barrett and Darnell (1967) presented evidence showing that the lack of either lethal or sublethal effects on small mammals (mice) still resulted in changes in the species composition of these animals following treatment with dimethoate. They postulated that the absence of any habitat effects other than an abrupt decline in insect density following treatment, resulted in the shift in small mammal composition from dominance by an omnivore to dominance by a herbivore. Such a change in species composition of small. mammals could occur following use of other insecticides, such as endrin, and would probably be viewed as undesirable by farmers and ranchers.

Intravenous injections of endrin in pigeons produceci visua] deficits (Revzin 1966). He concluded that the doses required to produce such perceptual deficits would be materially lower than those necessary to produce grossly observable behavioral changes, and that such deficits would probably reduce a bird's ability to avoid predators and compete for food.

Adult male bobwhite quail given 0.1 or 1.0 ppm endrin made $36 \%$ to $139 \%$ more errors when their performance was tested on nonspatial discrimination reversal tasks (Kreitzer 1980). The principal effect was inpairment of the ability to react appropriately to novel stimuli, with impajrment increasing from problem to problem at an exponential rate. This is significant because most natural stimuli (eg. appearance of a predator) are novel during the first spring and summer of a wild bird's life (Kreitzer 1980). 


\section{Human Health Concerns}

Endrin has been documented as being teratogenic (i.e. causes birth defects) in laboratory animals (Ottolenghi et al. 1973, Federal Register 1979). The EPA has also recommended that exposure to endrin should be avoided during pregnancy; additional precautions must be taken and protective clothing worn by all females working with endrin (Appendix C). Endrin has been found to be a carcinogen (Reuber 1979), however, those findings were not accepted by the EPA Cancer Assessment Committee. When carcinogenic proof is accepted, a pesticide is generally removed from use, although its use may continue depending on the level of risk to humans.

Federal agencies have established an "action level" for various pesticides in domestic meats which are to be sold for public consumption. Pesticide residues above such levels result in the embargo of the meat until further testing can be performed. The action level for endrin in fat of domestic meats is $0.3 \mathrm{ppm}$ (lipid basis); there is no similar determination for wild meat.

The World Health Organization has established, and the EPA adopted, $0.0002 \mathrm{mg} / \mathrm{kg}$ as the "acceptable daily intake" (ADI) level for endrin by humans. The ADI applies to chronic ingestion during an individual's lifetime.

Since the first Montana hunting seasons to open in fall 1981 were those for grouse, partridge, and archery-big game, collecting and testing of tissues for those species was implemented first. Waterfowl testing for endrin was also emphasized as those hunting seasons approached. 


\section{STUDY AREAS AND METHODS}

\section{Monitoring 1981 Operational Endrin Spraying}

Lack of precise knowledge of endrin application sites in March and April 1981 precluded both (1) pre-and postspray wildlife population studies, and (2) observing or collecting any endrin-exposed wildlife until several weeks postspray. Chances of finding sick or poisoned wildlife that long after endrin spraying were considered remote. Data gathered during summer and fall of 1981 would hopefully allow us to assess possible affects on wildlife which may have occurred earlier that year. More importantly, this effort could reveal potential secondary hazards to wild if e and humans that might consume endrin-contaminated wildife.

\section{Sample Collections}

\section{Aquatic}

Two fish kills in Sunday Creek (Custer County) in southeastern Montana in March 1981 prompted the collection and testing of fish tissues for pesticide residues. The first fish kill involved toxaphene and was not reported until the second, involving endrin, occurred about 2 weeks later. Notification by MDA that endrin was being applied extensively to grainfields east of the Continental Divide resulted in subsequent collection and testing of fish from 28 additional sites including 1 west of the Divide.

\section{Terrestrial}

Big game animals were collected using center-fire rifles. Birds were primarily collected with shotguns; a few were taken with .22 rifles. Small mammals were obtained mostly by trapping, although a few of the larger species were taken with shotguns or .22. Most animals appeared and behaved normally prior to being collected, except 3 animals reported as being sick ( 1 redtailed hawk, 1 golden eagle, and 1 mule deer), 1 duck found dead of unknown causes, and a white pelican wounded by a small caliber bullet.

A few road-killed animals were also sampled, including 2 deer, 2 great horned owls, 1 kestrel, and 1 sharp-tailed grouse. The history of endrin exposure for these animals was unknown.

Wild life collections were initiated in late April 1981. Although some of these were from, or adjacent to, known endrintreated fields, others were from known untreated sites (a mile or more from known treatment sites), or their exposure to endrin 
was unknown. Additional collections were made periodically through fall 1982 at a few sites from which positive endrin samples were taken in 1981. Early 1981 collections were largely at random; late 1981-1982 collections were not.

Collections in 1982 also included many samples obtained from areas treated with endrin that spring as part of the study of potential endrin alternatives and wildlife. These samples had known spray histories, and therefore a precise postspray interval could be assigned to each specimen. This allowed a better assessment of the 1981 data where accurate spray history (dates, actual sites, etc.) was not available.

\section{Collection Sites}

Areas from which terrestrial wildlife were collected for testing following 1981 endrin applications included diverse habitats over a wide area in Montana, principally east of the Continental Divide. The MDA selected several endin-treated fields and surrounding areas to monitor the fate of endrin in soils and vegetation as early as 15 March 1981 (Bain 1983).

Big game and upland game birds were generally obtained from upland habitats. When endrin contamination of waterfowl also became a major concern, areas containing standing bodies of water became focal points for collections. Those sites served as collecting areas throughout 1981 and into fall 1982. Other aquatic and migratory game birds, some upland game birds, and most passerine birds and small mammals were also obtained at or near those water areas.

Five sites, representative of those from which most wildife collections were obtained, are described below.

\section{Site 1}

This site is an area containing 4 small stock reservoirs and is located about 11 mi northwest of Miles City (Custer County) in southeastern Montana. The reservoirs occur on intermittent streams in a grazed sagebrush-grassland habitat. Each reservoir is used by ducks and Canada geese during spring and fall migrations, as nesting areas in some years (except that geese do not nest on the smallest reservoir), and for staging in late summer.

In 1981, Reservoir 1 (Fig. 7) covered about $1 \mathrm{~A}$, was $4 \mathrm{ft}$ deep, and was about $0.25 \mathrm{mi}$ from a sprayed winter wheat field. The endrin-treated field was not upstream from the reservoir. Reservoir 2 (Fig. 8), also about 1 A in size but only 6 in deep, had an endrin-treated winter wheat field within 100 yd of its margin, and also received runoff from this field. Reservoir 3 (Fig. 9) was the largest water body ( $4 \mathrm{~A}$ and $2 \mathrm{ft}$ deep) and was bordered by a large endrin-treated winter wheat field; endrin had been sprayed from a ground vehicle, pond margins were sprayed, 


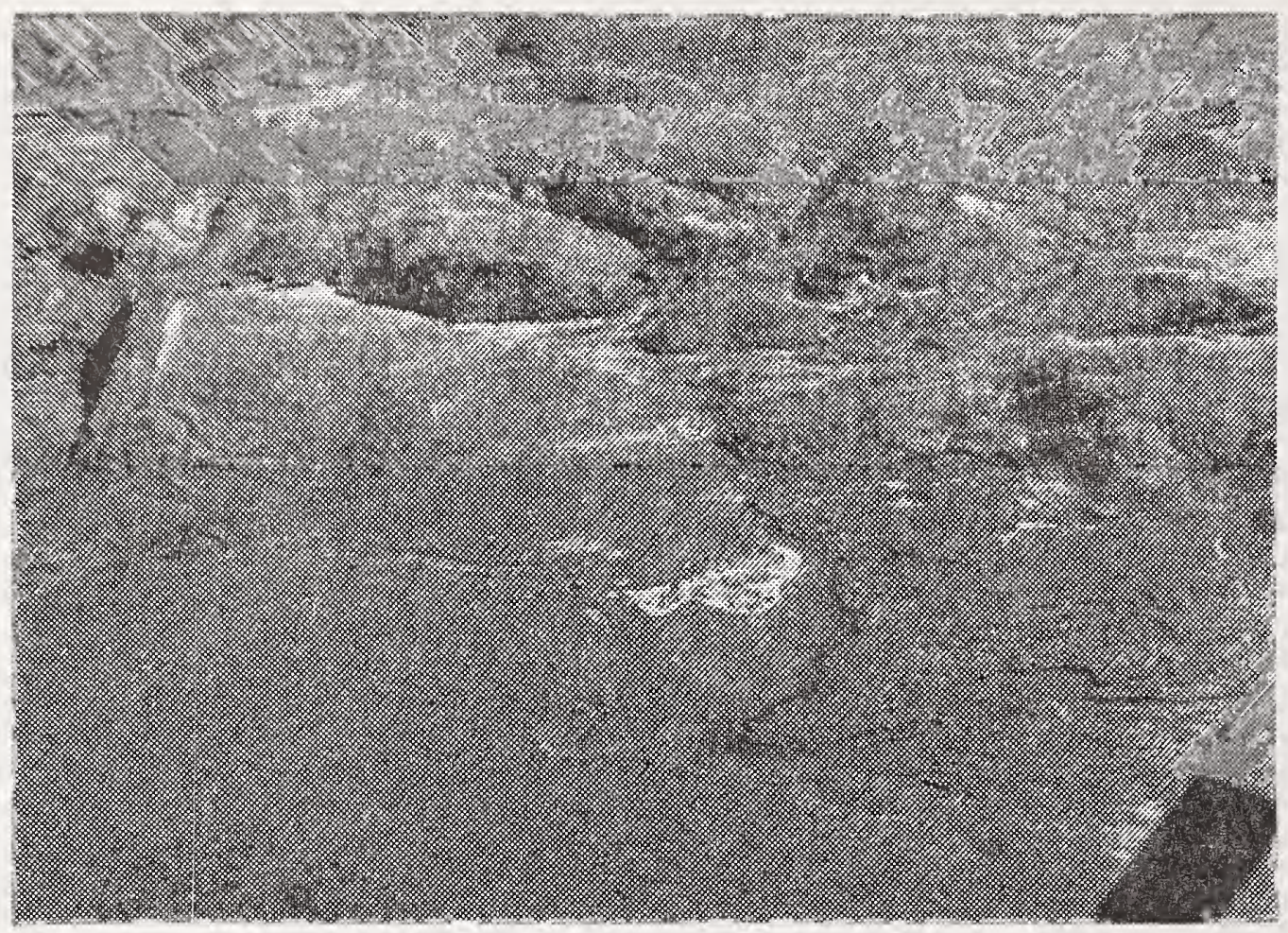

Figure 7. Reservoir 1 in sagebrush-grassland at site 1.

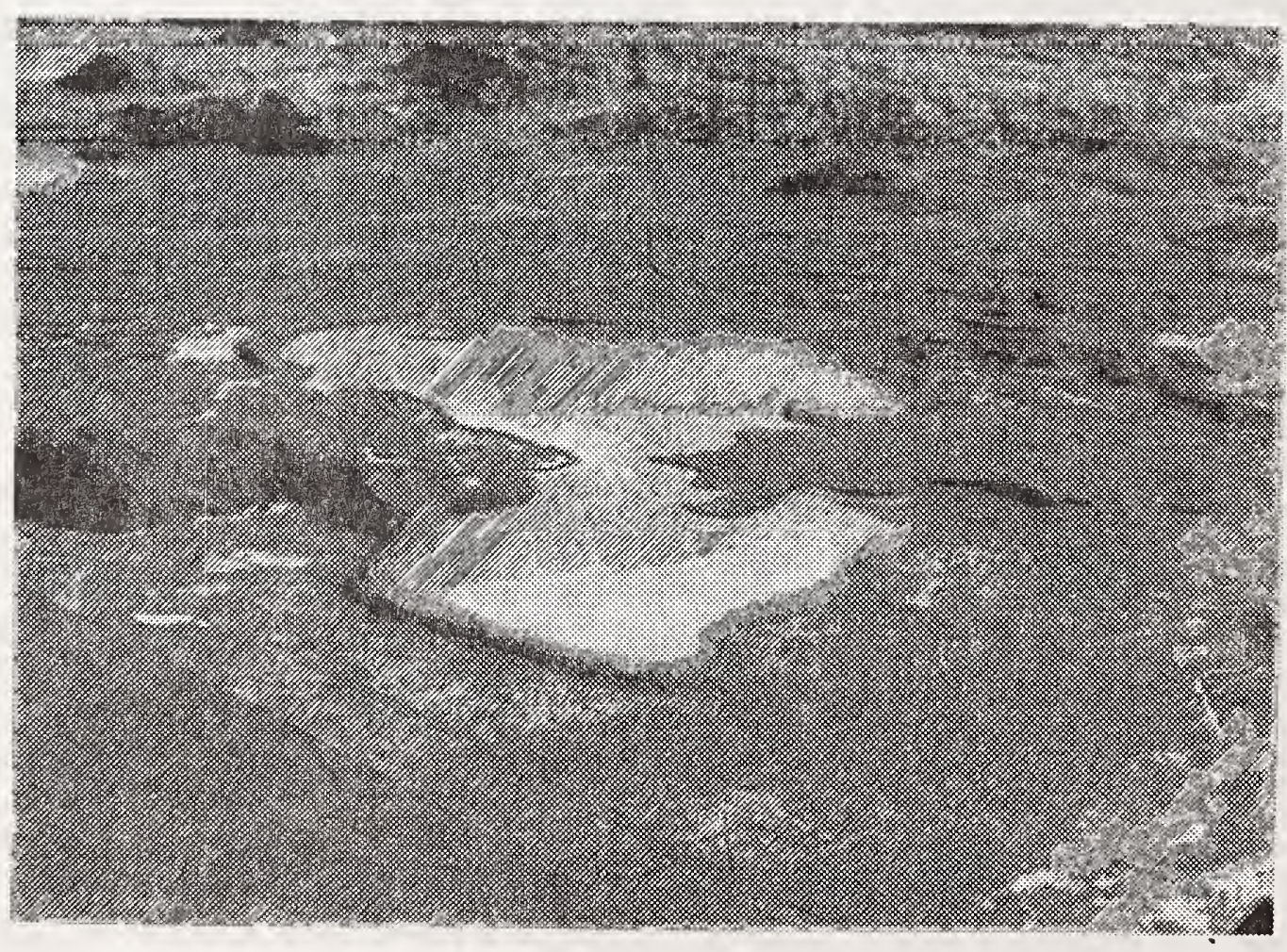

Figure 8. Reservoir 2 (Site 1) in sagebrush-grassland with drainage from a nearby endrin-treated wheat field (lower left corner). 


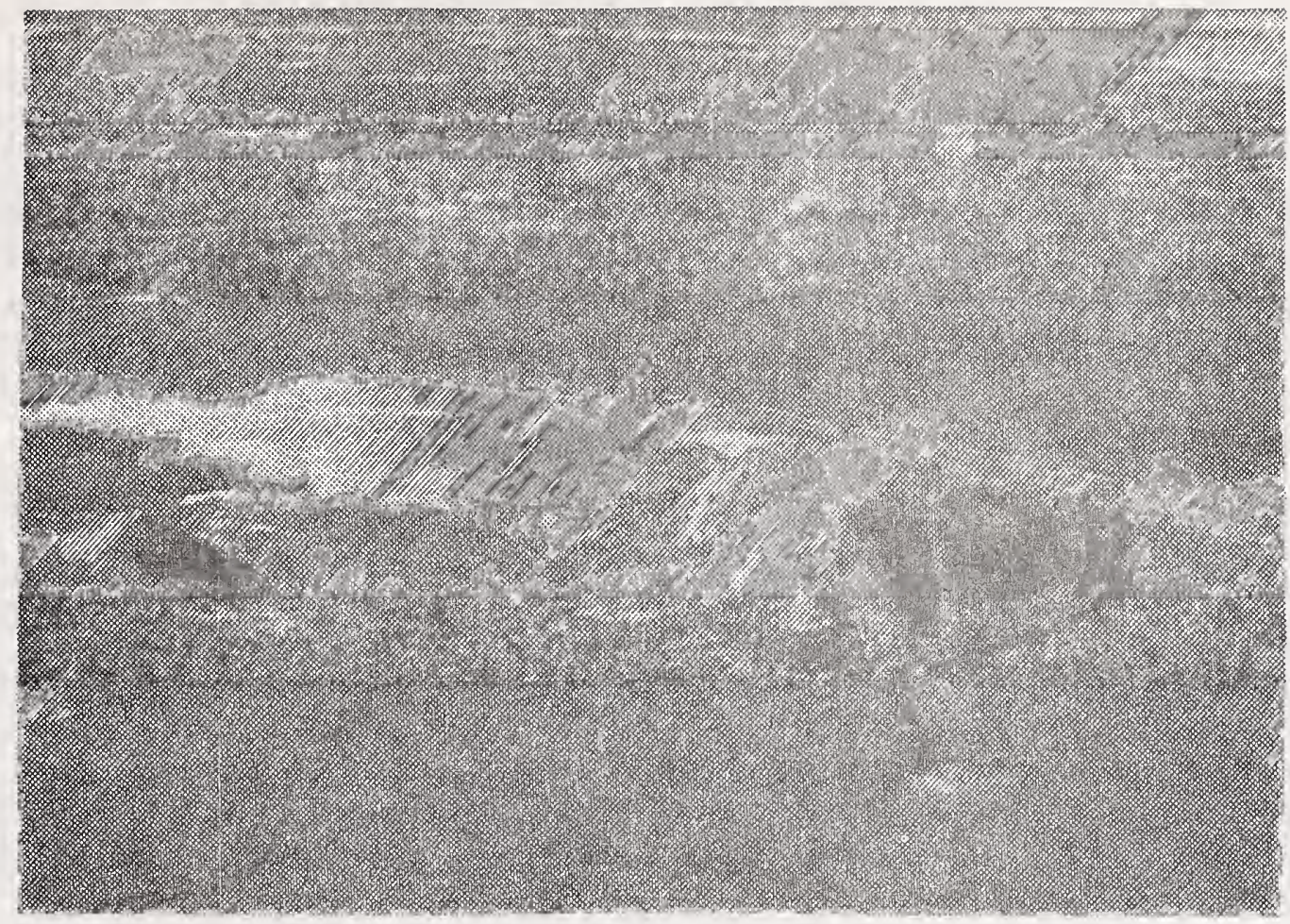

Figure 9. Reservoir 3 (Site 1) in sagebrush-grassland bordered by an endrintreated wheat field.

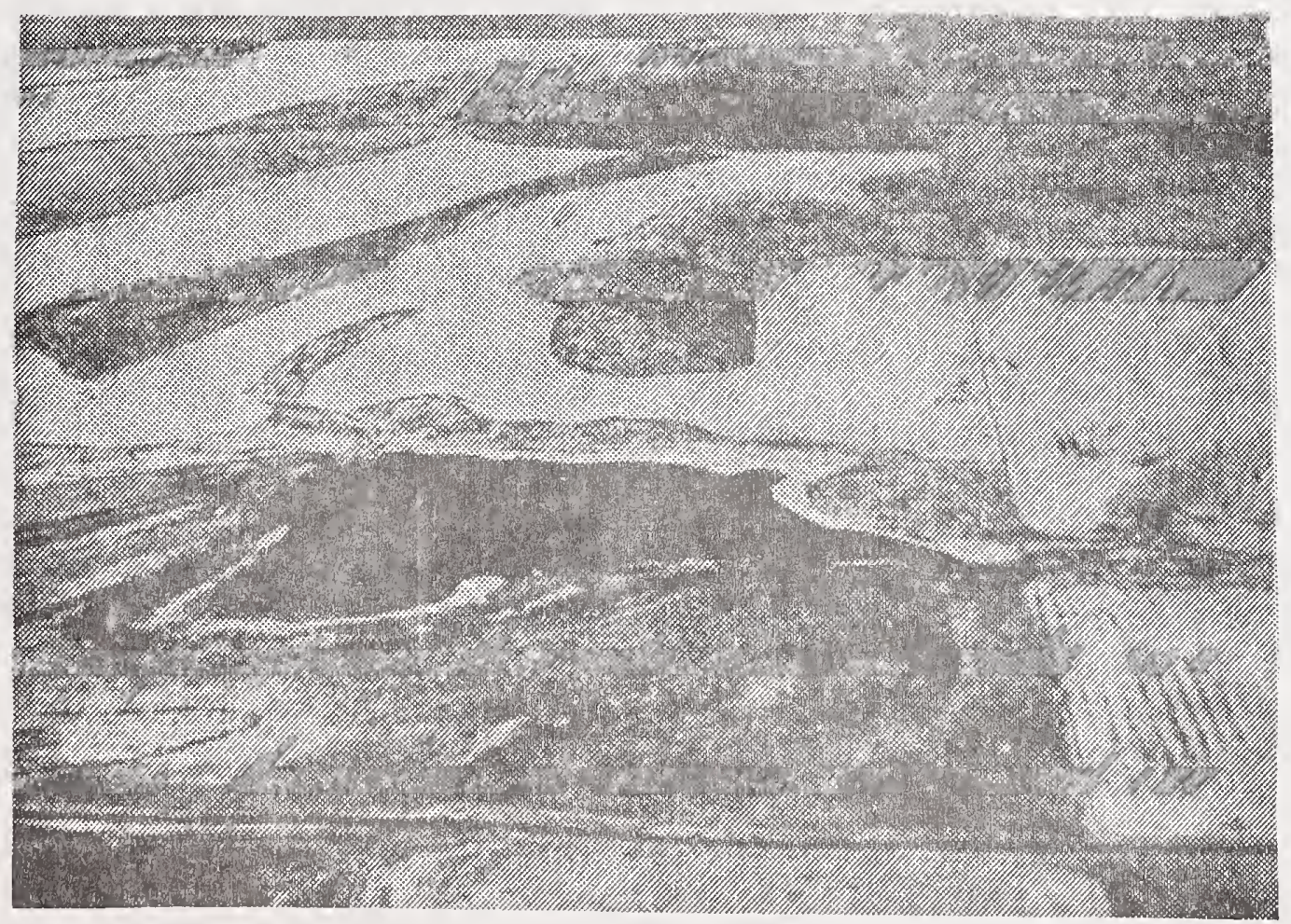

Figure 10. Reservoir at Site 5 inmediately below an endrin-treated wheat field (right side of photo). 
and there was undoubtedly endrin runoff into the reservoir. A fourth reservoir ( $0.5 \mathrm{~A}, 1 \mathrm{ft}$ deep) occurred within an eridrintreated winter wheat field and probably received endrin directly from the ground applications; this pond was used mostly by ducks during spring migration.

\section{Site_2}

South Sandstone Reservoir is $10 \mathrm{mi}$ southwest of Baker (Fallon County) in southeastern Montana. It includes 119 surface acres and is approximately $6 \mathrm{ft}$ deep. The surrounding area is grass rangeland, with some deciduous shrubs at the upper end of the reservoir, and little riparian vegetation along the shoreline. The basin which drains into the reservoir includes about $40 \mathrm{mi}^{2}$ and numerous endrin-treated grainfields (in 1981). Ducks and Canada geese use the reservoir for the same purposes as the reservoirs at Site 1, except that there is no nesting by Canada geese at South Sandstone.

\section{Site 3}

This site is located about $15 \mathrm{mi}$ northwest of Glendive (Dawson County) in extreme eastern Montana. The reservoir is at the junction of several intermittent streams in moderately grazed sagebrush-grass rangeland. Habitats above and below the reservoir are more mesic than those at Sites 1 and 2 , and are characterized by deciduous trees and shrubs. Rangeland communities surround the reservoir, but a 600 A endrin-treated wheat field was within 100 yd of one side. In addition, much of the basin below this reservoir has been converted to grainfields.

The reservoir covers about 3 surface acres, the water has a maximum depth of 12-15 ft, and the shallow edges have welldeveloped stands of bulrush and sedges. It is used by ducks and Canada geese during spring and fall migrations, and for nesting by ducks. Endrin-contaminated birds collected here would have probably contacted the endrin in nearby fields rather than from aquatic life forms in the pond because treated fields were downstream.

\section{Site_u}

Two reservoirs, representative of similar sites in Montana's "Wheat Triangle", characterize this site $28 \mathrm{mi}$ north of Great Falls in Chouteau County (northcentral), Montana. The reservoirs are about $1 \mathrm{mi}$ apart and $2-2.5 \mathrm{mj}$ from the Teton River. The first reservoir, about $1.5 \mathrm{~A}$ in size and $3-4 \mathrm{ft}$ deep, is located in a 2,800 A endrin-treated winter wheat field. It lies in ar: intermittent stream channel and the only native vegetation is short grasses and forbs in an upstream swale and around the edges. The other reservoir, about $12 \mathrm{~A}$ and lip to $20 \mathrm{ft}$ deep, is in a grass-forb rangeland at the junction of 2 intermittent 
streams, both of which drained the above, large wheat field; the upper edge of one "arm" of the reservoir contacted that treated field. The main part of the latter reservoir is within $0.25 \mathrm{mi}$ of that field, and the reservoir supports a rainbow trout fishery. Neither reservoir is bordered by emergent vegetation. Both reservoirs are used by migrating ducks and Canada geese, both are used by nesting ducks, and a whistling swan and a common loon were observed on the larger reservoir.

\section{Site 5}

This site included an irrigation and stock watering reservoir $3 \mathrm{mi}$ northwest of Clyde Park (Park County) in southcentral Montana (Eig. 10). The reservoir covers approximately 4 acres with a maximum depth of 6-8 ft. It is bordered in part by willows, and emergent aquatic vegetation occurs in suitable locations. The reservoir is almost entirely surrounded by a field that is used both as pasture and for hay production. Grain fields occur within close proximity on 2 sides of this pond, including 1 containing the upper part of the pond, and through which the inlet stream runs. This latter field was sprayed with endrin in 1981, while the spray history of the other field was unknown. Endrin could have reached this reservoir through drift, actual spraying of that portion within the treated field, or runoff from the treated field.

Wildife contact with endrin at any of these sites could have been by 1 or more of the following routes: direct contact at the time of spraying; in runoff water; and via the food chain (i.e. feeding on terrestrial and/or aquatic invertebrates, aquatic vegetation, or vegetation in treated fields).

\section{Preparation of Samples for Testing}

\section{Aqua $\underline{\underline{t}} \underline{\underline{i}} \underline{\mathrm{c}}$}

Fish collected for endrin analysis were wrapped in aluminum foil and frozen as soon as possible after collection. Preparation for analysis consisted of filleting the edible portions (to remove bones and scales) and removing slices (approximately $2 \mathrm{~cm}$ thick) from the anterior, mid, and posterior sections. Endrin analyses were completed by the analytical laboratory of the Montana Department of Health and Environmental Sciences (MDHES) in Helena.

\section{Terrestrial}

Most specimens were kept whole, wrapped in foil, and either put on ice and brought to the MDFWP wildlife laboratory in Bozeman, or frozen and transported to the lab at a later time. Big game and some other samples were processed (as above) by field personnel and transported to this lab. 
Preparation of samples in the Bozeman lab included: loggirg the specimens in and assigning them laboratory numbers; removing appropriate tissue(s); wrapping in foil (with appropriate identification); and freezing. In many instances it was necessary to combine tissues from 2 or more animals collected at the same time and site in order to have enough material for testing. In other instances more than one sample of the same tissue was removed from an individual animal and each was submitted to a different lab.

Tissue samples were prepared and forwarded to 1 of 4 laboratories; 3 governmental (MDA-Bozeman, EPA-Denver, and FWSPatuxent), and 1 private (Hazleton-Raltech, Inc.-Madison, Wiscorsin). Samples were hand delivered to MDA personnel for analysis at their Bozeman lab, or shipped on dry ice to the other labs.

\section{Analytical Procedures}

\section{Aquatic}

Slices from each fish were combined, cooled, and ground in a Hobart grinder prerinsed with acetone. Fish tissue was blended with methyl cyanide; endrin was then partitioned into petroleum ether, dried over anhydrous $\mathrm{Na}_{2} \mathrm{SO}_{4}$, and eluted through a florisil columin with $15 \%$ ethyl ether/petroleum ether (V/V). Endrin was finally quantified in the resulting concentrate by electron capture gas chromatography (U.S. Department of Health, Education and Welfare, Food and Drug Administration 1972, Horwitz et al. 1975.)

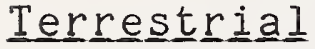

A variety of instrumentation and methodology were employed by the different labs to extract, cleanup, separate, and quantify chlorinated hydrocarbon residues in samples submitted by the MDFWP. All labs to which we submitted samples employ methods approved by federal agencies (i.e. USDA, FDA, EPA) and/or the Association of Official Analytical Chemists. However, methods employed for fatty tissues, nonfatty tissues, water, soils and sediment, etc. all differ from one another. In addition, methods for analysis of a given tissue (i.e fat) may vary at a given lab depending on the size of the sample available. In the interest of brevity, and also to avoid confusion and prevent errors in methodology from being introduced, detailed information on methodology employed by the various labs will not be presented here. Persons wishing such details should contact those labs directly. 
Residue Reporting

Chemical residues in tissues were provided by each laboratory as either nondetectable (below some established level) or at specific, calculated levels above the minimum detection level. Reference to nondetectable levels in this report does not mean that the compound was absent, but rather that analytical procedures did not permit reliable calculations of minimal residues that might have been present.

Detection levels varied between labs, between different tissues tested at the same lab, and also within a given tissue at the same lab; a very small sample results in a higher detection level than a larger amount of the same tissue. Where more than one detection level for a single tissue was reported, the higher level is the one used in this report. Maximum detection levels were $0.10 \mathrm{ppm}$ for PCB's and $0.05 \mathrm{ppm}$ for all other compounds.

Residues may be reported on both an "as received" or wet weight basis, and/or a lipid weight basis. With the exception of fat, residues are usually reported on a wet weight basis; i.e., based on the weight of the total sample tested. Although also reported on a wet weight basis, residues in fat are most often reported on a lipid weight basis; i.e., actual lipids are extracted from the sample and the residues are based only on the weight of the lipid fraction. When residues from the same sample are reported both ways, those given on a lipid weight basis are higher than those on a wet weight basis. Residues in most wildIife tissues from Montana are reported on a wet weight basis. The only residues reported on a lipid weight basis were from fat samples obtained in early 1981 collections. All residues are reported as parts per million (ppm).

Comparisons of our endrin residue data with federal action levels and ADI's established for domestic meats were submitted to federal, state, and private health authorities, the hunting and nonhunting public, and the Montana Fish and Game Commission for evaluation. The MDFWP did not interpret endrin residues in wild game meat and fat as they relate to human health, but relied on human health experts for such interpretations. The MDFWP followed similar procedures with compiling and analyzing residues of other chlorinated hydrocarbons found in wildlife tissues.

\section{Public Awareness Survey}

The MDFWP conducted a telephone interview survey of a sample of resident game bird license holders following 1982 hunting seasons to measure (1) public awareness of potential pesticide contamination of Montana upland game birds and waterfowl, and (2) whether precautions regarding preparation and cooking of birds were followed. The survey was part of the larger statewide wildlife harvest survey. Names of 2001982 resident bird license buyers were randomly drawn for this survey. Responderis were 
asked about their awareness of pesticide contamination of wildlife, sources of information, whether or not they continued to hunt, numbers of birds that had been or would be consumed, the sex and age composition of household members, whether or not pregnant or nursing women were included in the household, and whether or not preparation and cooking procedures adopted by the Montana Fish and Game Commission had been followed (Appendix E).

\section{Alternative Insecticide-Wildlife Studies}

In light of undesirable environmental consequences from continued endrin treatment of small grains in Montana, the MDA and MDFWP recognized tre importance of replacing endrin with an effective, yet environmentally less harmful, method of cutworm control. The 2 departments cooperated in a study of the efficacy, fate, and effects on wildiife of 2 potential alternative chemicals in spring 1982, under more or less "operational" field conditions. Endrin was also studied as a "standard" for comparison purposes. The EPA approved a Section 18 specific exemption from registration for the use of an organophosphate, chlorpyrifos (Lorsban), and a synthetic pyrethroid, permethrin (Ambush, Pounce) for cutworm control in small grains in Montana in 1982.

The MDA received and verified reports of cutworm activity, and enlisted the cooperation of private landowners in conducting the studies on their lands. It was hoped that enough area in one vicinity would permit the study of all 3 compounds in close proximity to one another. once candidate study areas were found, the MDFWP was notified so that the potential for wildlife studies could be evaluated prior to final study site selection.

Cutworm populations in 1982 were reduced, and their development was delayed corisiderably, from 1981. Hence, the first study area was not selected until 20 May, near Vaughn (Cascade County) in northcentral Montana. A second area, near Shawmut (Wheatland County) in central Montana, was evaluated on 25 May. A trird area, evaluated on 26 May, was north of Lavina (Golden Valley and Musselshell Counties), also in central Montana. Although each site was less than desirable for wildlife studies, timing of insecticide applications for cutworm control dictated their selection as study areas.

The first 2 study areas were relatively small, and only one chemical treatment was applied to each. These included permethrin (Ambush) on the plot near Vaughn, and chlorpyrifos on the plot near Shawmut. Control plots were also studied near each treatment plot. Because of the larger area near Lavina, all 3 chemical treatments (eridrin, chlorpyrifos, and pernethrin) were applied in the same vicinity. Because the grower in this latter area wanted to apply treatments as rapidly as possible, no prespray wildife population data were obtained and no control plot was established. 
Pesticide drift was monitored in 2 field plots, one near Vaughn (Fig. 11) that was sprayed with permethrin and a second near Lavina (Fig. 12) that was sprayed with endrin. The chlorpyrifos plot near Shawmut was sprayed before monjtoring equipment could be put in place. Details of the application conditions and equipment used are given in Appendix D. Biological monitoring consisted of spacing beakers containing Daphnia magna at various intervals downwind from the study plot, beginning in the spray plot itself and moving downwind. Study intervals were 10, 35 , $85,185,385,585,785,985$, and 1185 ft outside the treatment plot. Daphnia were counted and placed into $250 \mathrm{ml}$ beakers filled with about $200 \mathrm{ml}$ well water immediately prior to spraying. Two beakers, containing 5 daphnia each, were positioned at each interval. Beakers were retrieved and daphnia mortality was recorded in each treatment for each interval at 1, 2, 4, 6, and $24 \mathrm{hr}$ intervals following insecticide application.

Spray drift in the area surrounding the study plots is being estimated using the CGB Forest Spray Model of the USFS (Davis, California). Unfortunately, a model coefficient used to describe droplet evaporation was found to be in error and completion of our analyses is pending correction of this deficiency.

\section{Terrestrial Surveys}

Small mammal and breeding bird censuses were conducted on treated and adjacent untreated control plots whenever allowed by prespray intervals. These included 1 plot adjacent to a chlorpyrifos-treated area and its control plot, as well as 2 plots ( 1 in stubble and 1 in native grassland) adjacent to a permethrin-treated area, and their control (1) plot. Bird censuses were conducted on belt transects 450 yd long by 100 yd wide (Mikol 1980). Transects were walked between $1 / 2$ hr before and 3 hrs after sunrise, when windspeeds did not exceed 10-12 mph. Censuses were conducted at least 3 times prior to spraying on each transect; this was followed by at least 2 days postspray "rest", and then 3 additional censuses were made. Pre- and postspray bird populations, expressed as birds/100 acres, were estimated from transect data using the method of Balph et al. (1977). Searches for bird nests were also conducted on and adjacent to treatment and control transects, as well as around treated plots which were not censused. All located nests were visited periodically thereafter to determine their fate.

Small mammal traplines followed the centerline of each bird transect and consisted of 46 stations spaced 10 yd apart, with 1 Sherman live trap at each station. The small mammal trapping regime followed that for bird censuses. All captured specimens were individually marked by toe clipping and released at their capture site. Estimates of pre-and postspray small mammal populations were made using Chapman's modification of the Petersen-Lincoln index (White et al. 1982). The deer mouse was 

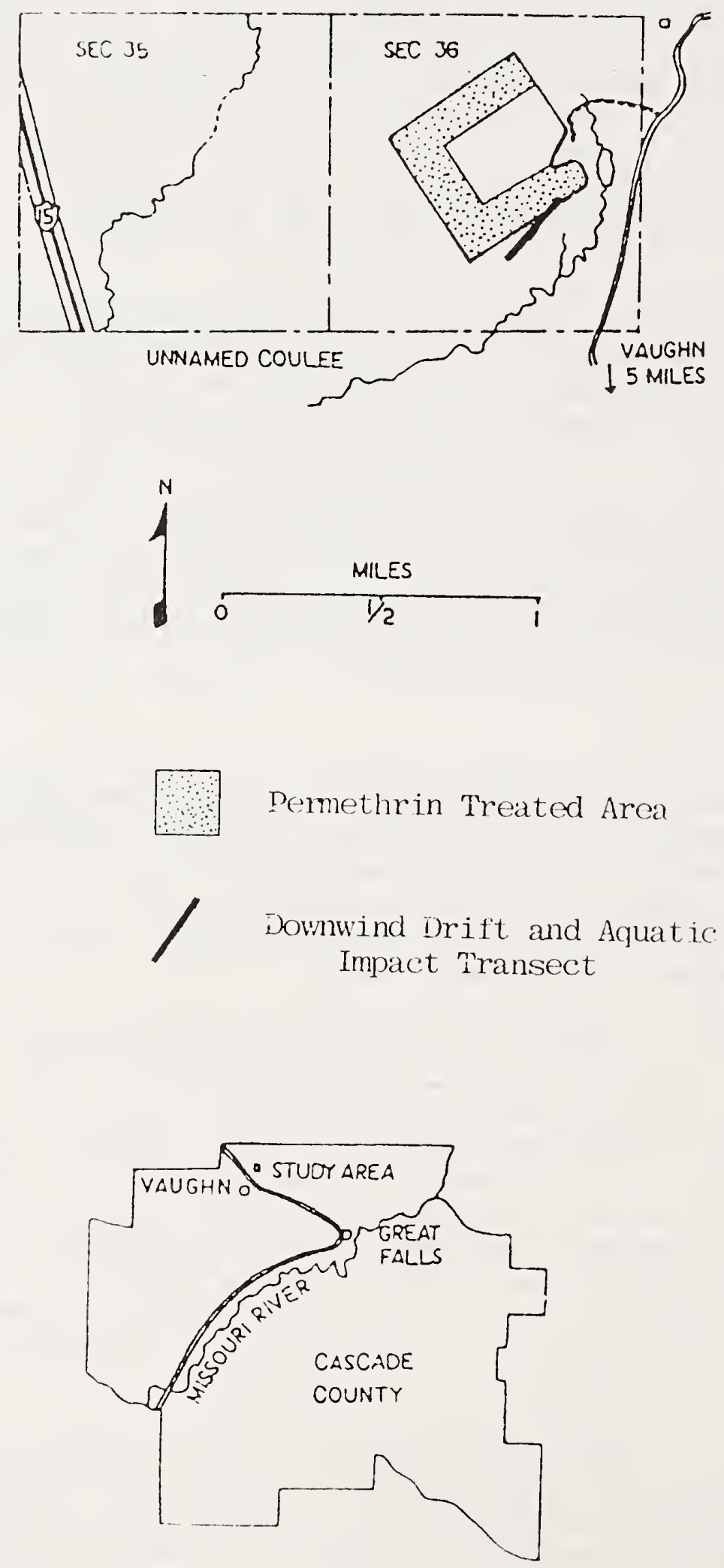

Figure 11. Permethrin treatment study area near Vaughn. 

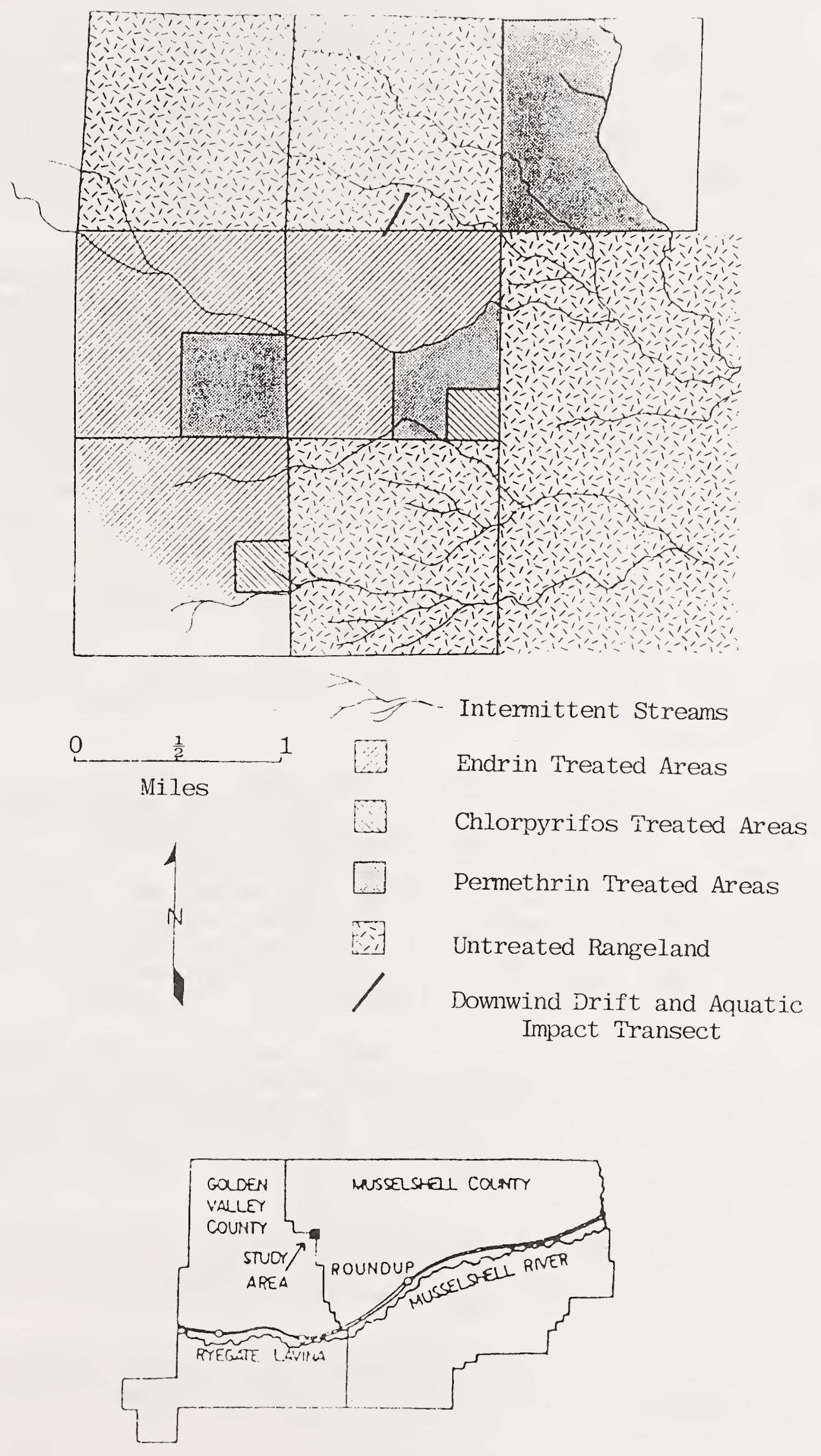
Figure 12. Map of Lavina study area showing location of various insecticide
treatments. 
the only small mammal species which occurred on all study plots and in any numbers. Therefore, small riammal population estimates are based solely on this species. As a crude check on effects of these chemicals on small mammal populations, tre percentage of marked individuals present at the end of the prespray trapping period that were subsequently captured in the postspray trapring period was calculated for each treated and control area.

Because chlorpyrifos belongs to a group of chemicals (organophosphates) which act by blocking action of the enzyme cholinesterase, small birds (horned larks and McCown's longspurs) were collected from, and adjacent to, chlorpyrifos-treated areas at various intervals following spraying to determine brain cholinesterase (ChE) levels. Control specimens of the same species were obtained from the same areas prior to spraying or from untreated rangeland $>1 \mathrm{mi}$. from sprayed fields. All specimens were field tagged, wrapped in aluminum foil and immediately placed in insulated containers with solid $\mathrm{CO}_{2}$ and air expressied to the Denver Wildlife Research Center. Specimens were stored at $-70^{\circ} \mathrm{C}$ in an ultra-cold freezer until processed, at which time they were thawed, brain tissues were excised, and ChE activity was determined using the colorimetric method of Ellman et al. (1961) as modified by Hill and Fleming (1982). Brains damaged by shot pellets were not analyzed. Depression of ChE activity in birds from treated areas was expressed as a percentage of normal in control specimens.

Food habits of horned larks and McCown's longspurs collected for ChE analysis were determined by excising the forestomach and muscular stomach, removing, and weighing the contents. Stomach contents were then sorted into animal, plant, and mineral material, and each group was visually estimated as a proportion of the total stomach contents. Random samples of sorted materials were weighed as a check on the estimates. Only animal and plant portions (adjusted to $100 \%$ of the sample) of the stomach contents were utilized to determine food habits.

Brain ChE activity data were analyzed by 1-way ANOVA and means were separated with Duncan's new multjple range test, while food habits mean values, and small mammal and breeding bird population estimates were compared by Students t-tests (Steel and Torrie 1980). Statistical significance is based on the $5 \%$ probabiljty level urless stated ctherwise.

Feeding trials llave shown very low acute oral toxicity of permethrin to both birds and mammals. Therefore, no direct mortality was expected, and no collection of samples to test for residues was attempted.

Collections of birds and larger species of small mammals, as well as lab and analytical procedures were the same as in 1981. 


\section{Other Chlorinated Hydrocarbon Compounds}

The private lab reported detectable levels of other chlorinated hydrocarbons, including PCB's, in addition to endrin. Detection of heptachlor, and its major metabolite heptachlor epoxide, became a concern because of their toxicity to wild ife and documented carcinogenicity. Although four pheasants were collected in fall 1982 specifically to test for heptachlor compounds, most samples were collected to test for endrin and not for other compounds. Therefore, test results represent random, baseline (or background) levels of contamination of Montana wildIife for those chemicals. Additionally, since the majority of 1981 samples were tested at labs that reported only endrin residues, results for other compounds include far fewer samples. Analytical procedures for these compounds were the same as for endrin. 


\section{Early Chronology of Events}

The MDFWP first learned of anticipated endrin use in late February 1981, when Union Carbide Company requested a special local need registration for use of carbaryl to control armyworms in cereal grains. MDFWP responded with, (1) support of the request, (2) opposition to the use of chlorinated hydrocarbons, and (3) a request to be informed when and where endrin was to be applied.

A fish die-off was reported in Sunday Creek, in Custer County in late March (Fig. 13). It was learned later that this was the second such fish kill in this stream, the first having occurred about 2 weeks earlier. Samples of dead fish from the site (tested by the MDA) confirmed the presence of endrin and of toxaphene.

Due to Montana's pesticide reporting system, locations of endrin-treated fields remained unknown until several weeks after spraying was completed. This precluded collection of pretreatment and immediate posttreatment wildlife population data as well as conducting searches for wildlife carcasses. However, direct mortality of wildlife exposed to freshly sprayed endrin cannot be ruled out; residues on vegetation following 1981 spraying were high enough for direct mortality of birds (Heath et al. 1972b) to have occurred.

\section{Aquatic Wildlife}

Fish were collected from 29 sites in Montana in 1981, primarily from the Missouri and Yellowstone Rivers and their tributaries (Fig. 14). Endrin was present at detectable levels in $23 \%$ of the 75 fish samples tested ( $T a b l e ~ 8)$. None of the detectable residues exceeded FDA's action levels for endrin in fish; the highest concentration was $0.04 \mathrm{ppm}$ (wet weight) in 2 composite samples of several species from Sunday Creek (site 4, Fig. 14). Although endrin occurred at low levels in fish, the time interval between fish die-offs and our sampling would have permitted elimination of most endrin from surviving fish.

\section{Terrestrial Wildlife}

Resident

Although 1 sharp-tailed grouse and 1 pheasant were collected in April and May 1981, respectively, most initial sampling ano 


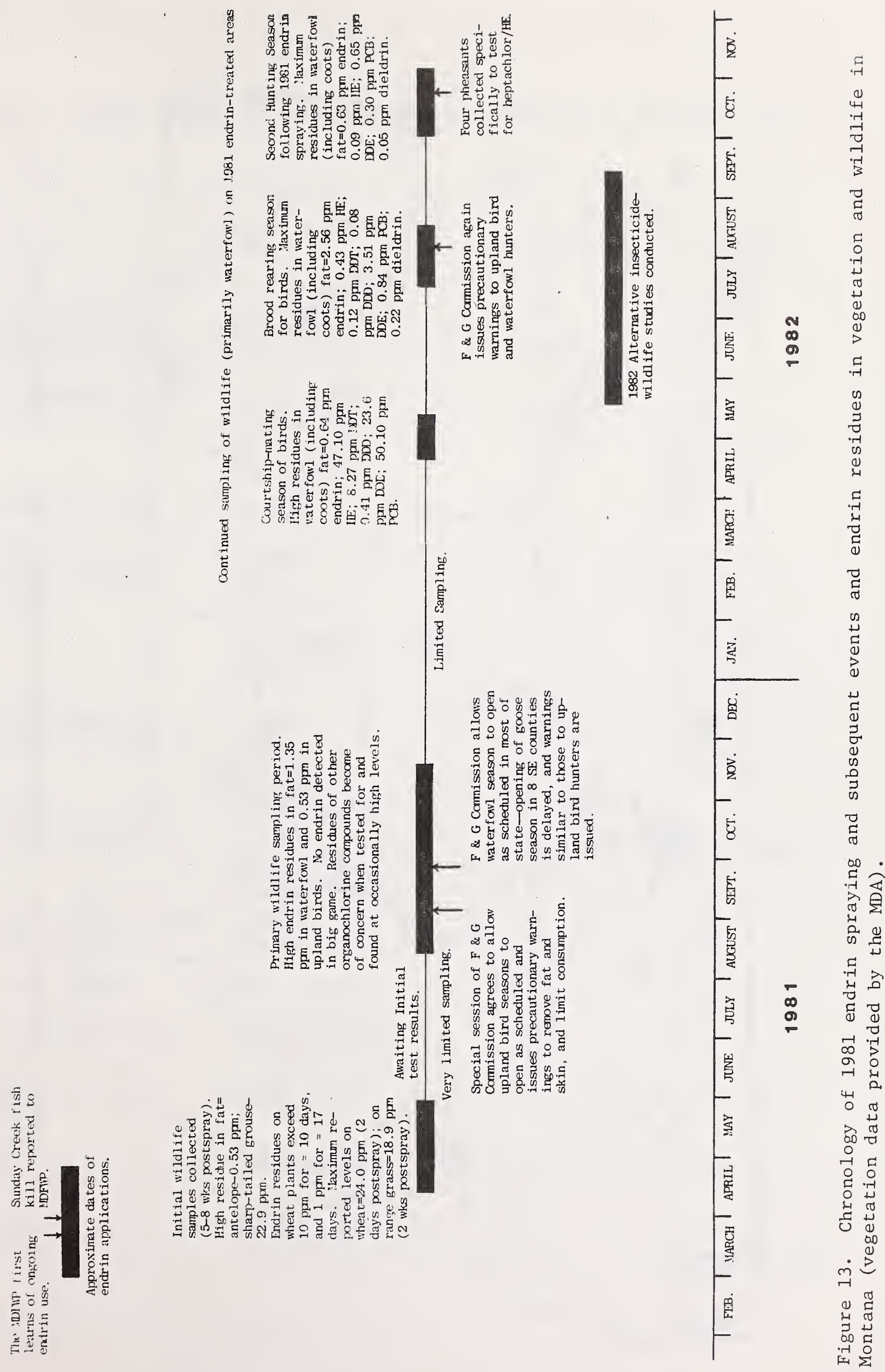




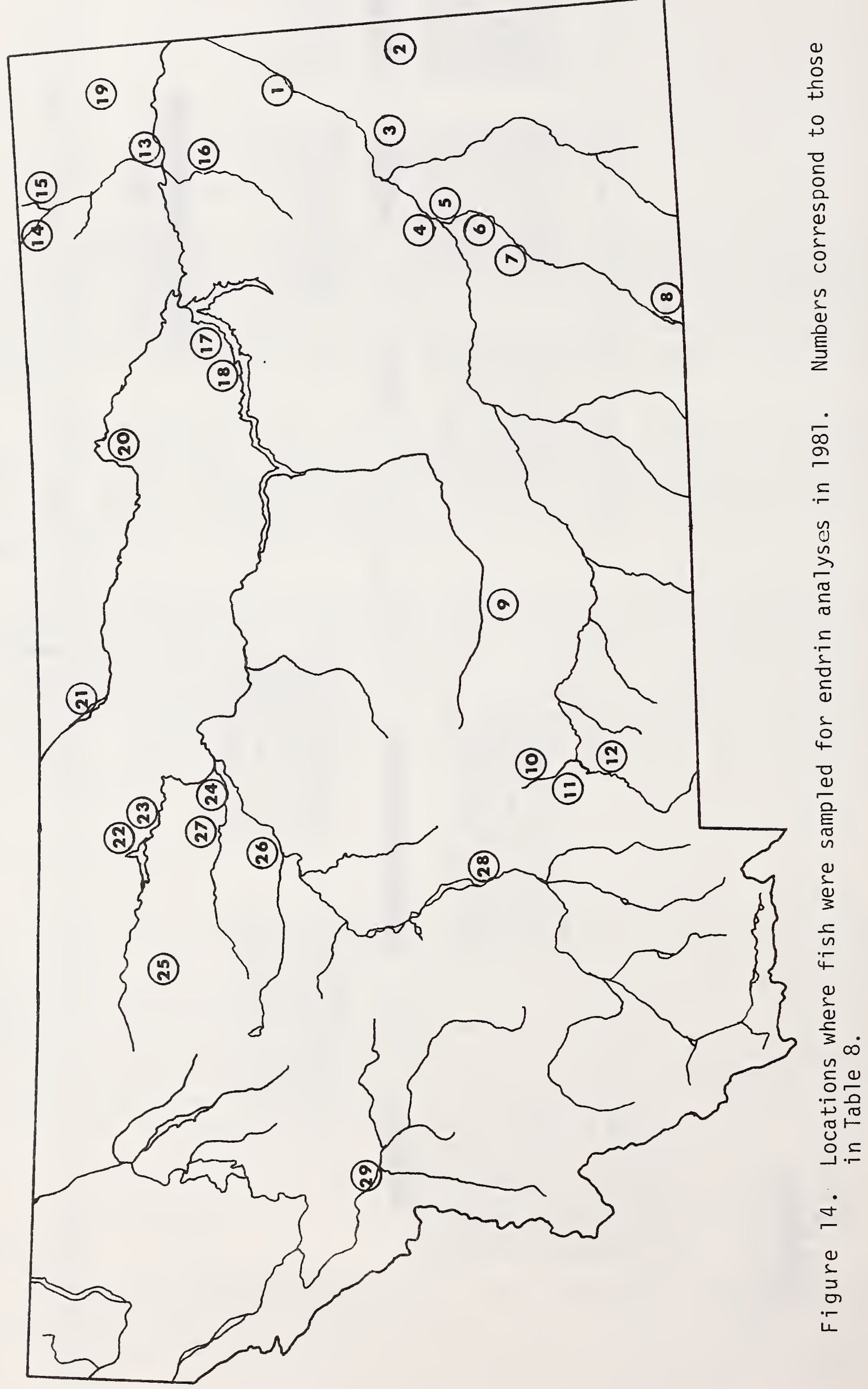


Table 8. Endrin residues in fish from selected locations in Montana during 1981.

Site No, and

Jocation

Species

No.

Samples

Fndrin $(\mu g / g$, wet tissinc)

1 Yellowstone R. ,

Goldeye

downstream from

Sauger

Intake diversion

Shovelnose sturgeon

$\begin{array}{lr}11 & <0.002 \\ 1 & <0.002 \\ 1 & 0.003\end{array}$

2 So. Sandstone Res. Black bullhead

Northern pike

Walleye

Yellow perch

$<0.002$

$1 \quad 0.011$

$2 \quad 0.002, .004$

$1<0.002$

3 O'Fallon Creek

Goldeye

1

0.029

4 Yellowstone R.,

Channel catfish

mouth of Sunday

Drum

Goldeye

Sauger

Composite of several

species

$\begin{array}{ll}1 & <0.002 \\ 1 & <0.002 \\ 11 / & <0.002 \\ 1 & <0.002 \\ 3 & 0.03,0.04 \\ & 0.04\end{array}$

5 Yellowstone R.,

Burbot

mouth of Tongue $R$. Goldeye

$11<0.002$

Walleye

1

1

$<0.002$

$<0.002$

6 Tonque R., at

Channel catfish

12 Mile Dam

Soldeye

2)

Sauger

Smallmouth bass

1

2

2

1

$<0.002$ (2)

Sauger

Smallmouth bass

1

1

$<0.002, .005$

$<0.002$

7 Tongue R., at SH diversion dam

White crappie

1

$<0.002$

.007

8 Tongue R. Res.

Rainbow trout

White crappie

$11 /<0.002$

11 $\quad<0.002$

10 Shields R., at Clyde Pk. Bridge

Brown trout

1

$<0.002$

11 Shields R., at Chad- Brown trout

1

$<0.002$ bourne diversion

12 Yellowstone R.,

Brown trout near Mill Creek

Mountain whitefish

4

$<0.005(4)$

$4<0.005$

(2), .006,

.014

1.

$<0.002$ 
Site No. and Location
Species

No.

Samples
Endrin $(\mu \mathrm{g} / \mathrm{g}$, wet tissue)
14 Middle Fk. of Poplar R.

15 E. Fk. of Poplar R. Northern pike

16 Redwater River

17 Ft. Peck Res, near Northern pike So. Fk. Duck Creek

18 Ft. Peck Res.

Buffalo

Goldeye

Northern pike

19 Medicine Lake Nat'1 Northern pike Wildlife Refuge

20 Nelson Res.

21 Fresno Pes.

22 Tiber Res.

23 Marias River

24 Teton River

25 Lake Francis

26 Cochrane Res.

27 See Site 4

(Pp. 36-37)

28 Missouri R, at Toston

29 Clark Fork River below Missoula
Northern pike

Lake whitefish

Northern pike

valleye

Channel catfish

Northern pike

Burbot

Whitefish

Toldeye

Northern pike

Brown trout

Rainbow trout

Brown trout

Rainbow trout

Thitefish
1
1
1

1

2

1

1

1

1

1

1

1

1

1

1

1

1

1

1

1

1

1

2

$<0.002$

6

$<0.002$ (6)

$<0.002$

$<0.002$

$<0.002$

$<0.002$

$<0.002, .002$

$<0.002$

0.002

0.003

$<0.002$

0.002

$<0.002$

$<0.002$

$<0.002$

$<0.002$

$<0.002$

$<0.002$

$<0.002$

$<0.002$

$<0.002$

$<0.002$

.003

5

2/ Analytical problems; no results obtained. 
testing of resident wildlife for endrin residues involved big game species.

Big Game. A limited number of early test results revealed that big game, except for 1 pronghorn, contained either undetectable or relatively low levels of endrin in their fat. Additional big game fat samples obtained sporadically through July 1982 , plus other tissues sampled (liver, meat, and brain), also showed little or no endrin accumulation in those species (Table 9). The low frequency of endrin residues was attributed to several factors: wheat fields are not prime big game habitat (with the possible exception of when they are the only green vegetation available); many of the samples tested did not come from known sprayed areas; 5-6 weeks elapsed between treatments and collection of earliest samples; and, endrin is eliminated rapidly from vertebrates, especially mammals (Brooks 1974a).

Upland Game Birds. Limited eariy test results from partridge, turkey, pheasant, and sage grouse showed undetectable or low levels of endrin in fat samples. Additional samples of fat and other tissues collected from those species on an intermittent basis through October 1982 gave similar results (Table 10).

Most early sharp-tailed grouse fat samples also contained relatively low endrin residue levels. However, 3 samples had residue levels exceeding the USDA'S action level. This precipitated additional sampling of upland birds, with emphasis on sharptails, which continued through early fall 1982, and included other tissues as well as fat (Table 10). An EPA toxicologist was asked for his opinion regarding human consumption of birds containing residues of this magnitude. He concluded that although the endrin action level had been exceeded in several instances, human ADI levels for endrin were within safe limits if certain precautions, such as removing and discarding the skin and fat, were followed. Based on those recommendations the Montana Fish and Game Commission decided to allow the upland game bird and big game archery seasons to proceed as scheduled. They further cautioned grouse and partridge hunters to remove and discard the skin, internal organs, and fat from harvested birds and to limit consumption (Appendix F).

Although fat samples from the sharptail collected in April 1981 (reportedly 7 weeks following endrin treatment) were submitted to 2 labs, one did not analyze their sample, and the second sample was lost in a lab accident. Another fat sample was submitted, but it was October, well after the Fish and Game Commission's decision on bird seasons was made, before the results (22.9 ppm endrin) were received. Endrin residues in other tissues of this bird were: meat, $0.75 \mathrm{ppm}$; brain, $0.30 \mathrm{ppm}$; and crop contents, $2.54 \mathrm{ppm}$. Endrin residues in this sharptail's crop contents were over 3 times greater than dietary levels $(0.75$ ppm) found to impair reproduction of screech owls (otus asio) 


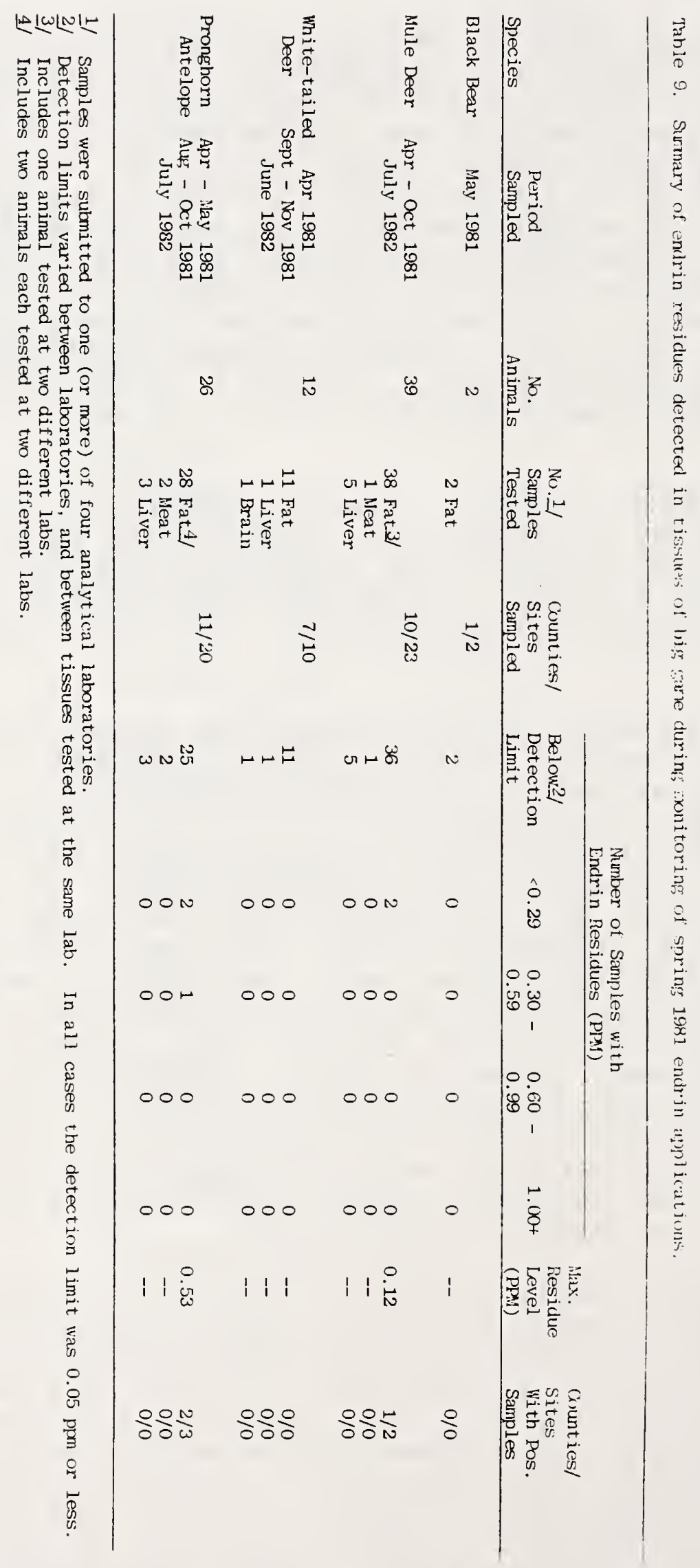




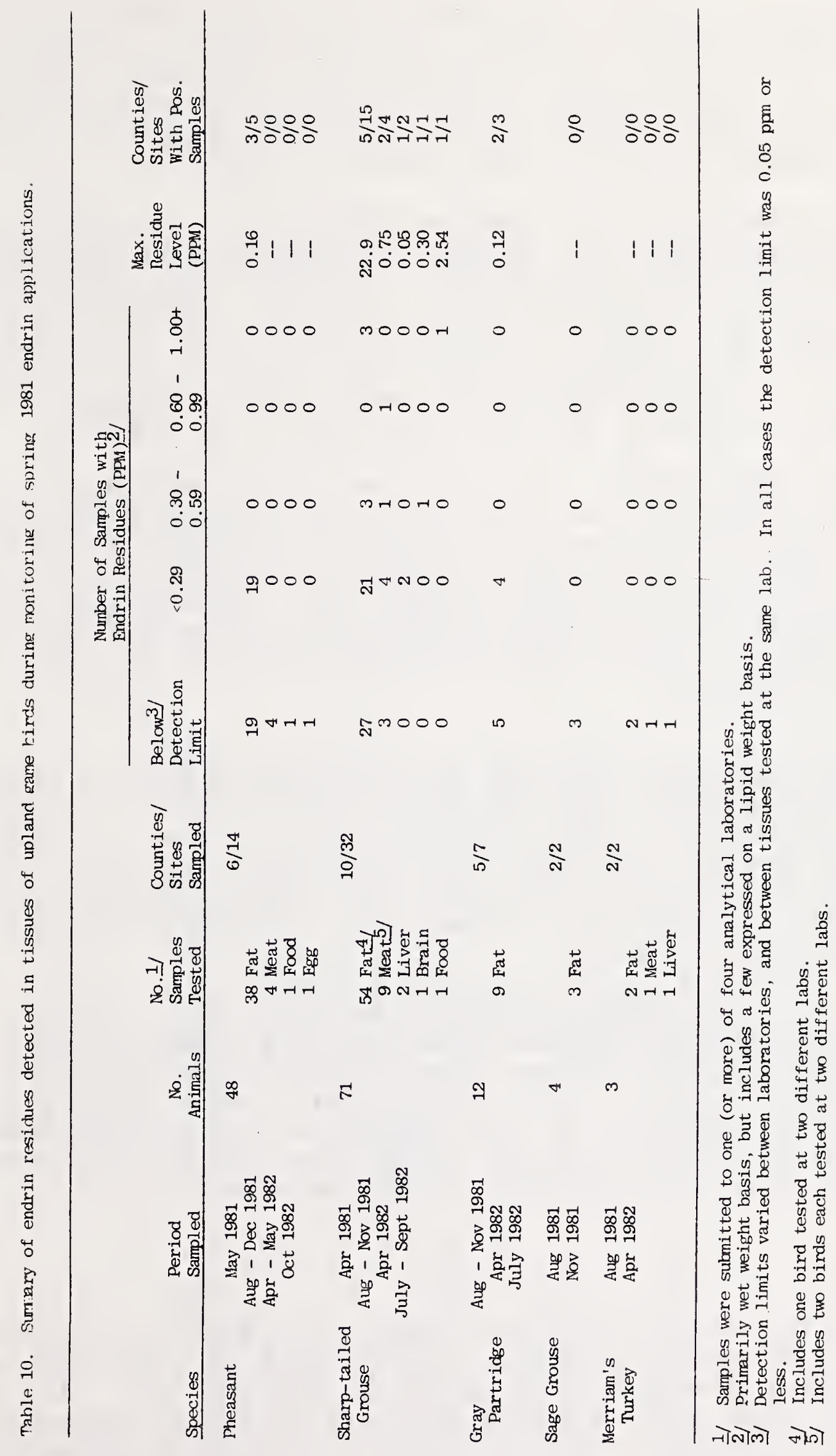


(Fleming et al. 1982). Residues in the meat of this bird approached the highest carcass, or whole body, residues in owls tested after being on this diet for up to 83 days. This suggested that even if nodirect mortality occurred (see later discussion), reduced population levels of sharptails could have. occurred through reduced production of young.

Three sharptail fat samples (two 2-bird composite samples and one 4-bird composite sample) from birds taken less than a month before the opening of the 1981 hunting season had endrin residues of 0.3 (the USDA action level) to $0.53 \mathrm{ppm}$ endrin. Meat samples from the 3 pools of birds were all positive for endrin (0.0017-0.003 ppm) as was the single liver sample tested $(0.05 \mathrm{ppm})$. A single sharptail taken in september, during the grouse hunting season, had $2.02 \mathrm{ppm}$ endrin in its fat.

These data showed that at least some sharptails contained high endrin residues for 5-6 months following endrin spraying, with a few greatly exceeding the USDA action level during the hunting season. They also indicated that the Fish and Game Commission's precautions to upland bird hunters were warranted. Possibly greater restrictions could have been imposed (at least for sharptails) if the data had been available at the time they made their decision.

Small Mammals. Testing of resident wildlife samples was expanded to include small mammals in fall 1981. Samples were obtained primarily from sites where other species with detectable endrin residues had been taken earlier. Sampling continued periodically through May 1982. Most samples were tested for 12 -ketoendrin as well as endrin, PCB's, and other chlorinated hydrocarbons.

Five to 13 months had elapsed between spraying and sampling, and may be the reason that residue levels of both endrin and/or 12-ketoendrin in these samples were undetectable or at low levels ( $\mathrm{Table}$ 11). It is significant that both endrin and ketoendrin were present in the tissues of a few small mammals for over 1 year following spraying, thus providing a long-term source of contamination for predatory birds and mammals.

\section{Migratory}

A great number of wildlife species spend only a part of the year within Montana's borders. While many of these are consumed by humans, the greatest proportion of them are not. All of these species are important because they are food for predators or are predatory in nature. Endrin contamination of predators is of concern because those species are at or near the top of often complex food chains, a position also held by humans. Thus, predators often serve as early indicators of problems with environmental contamination that ultimately concern man. 


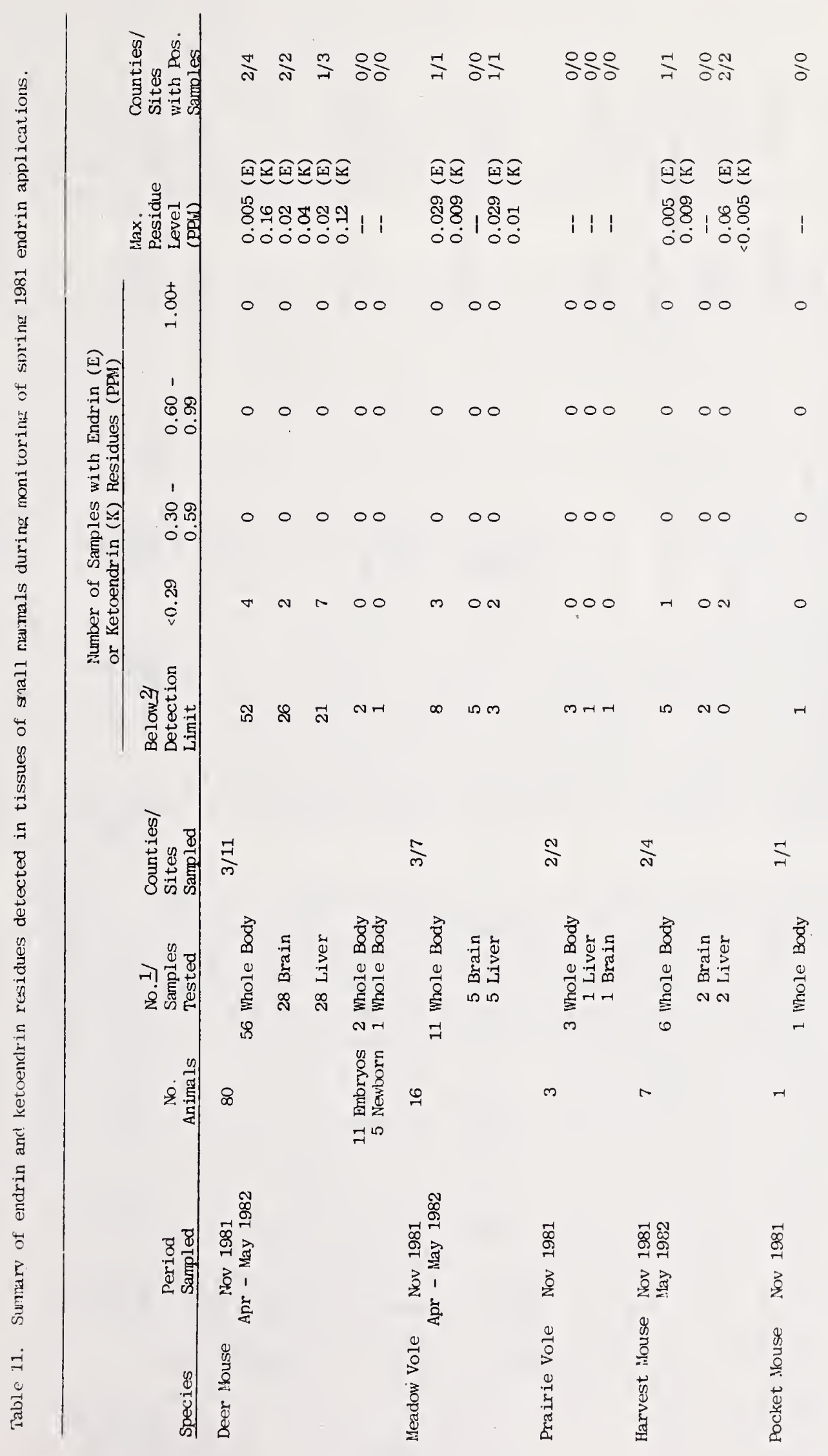




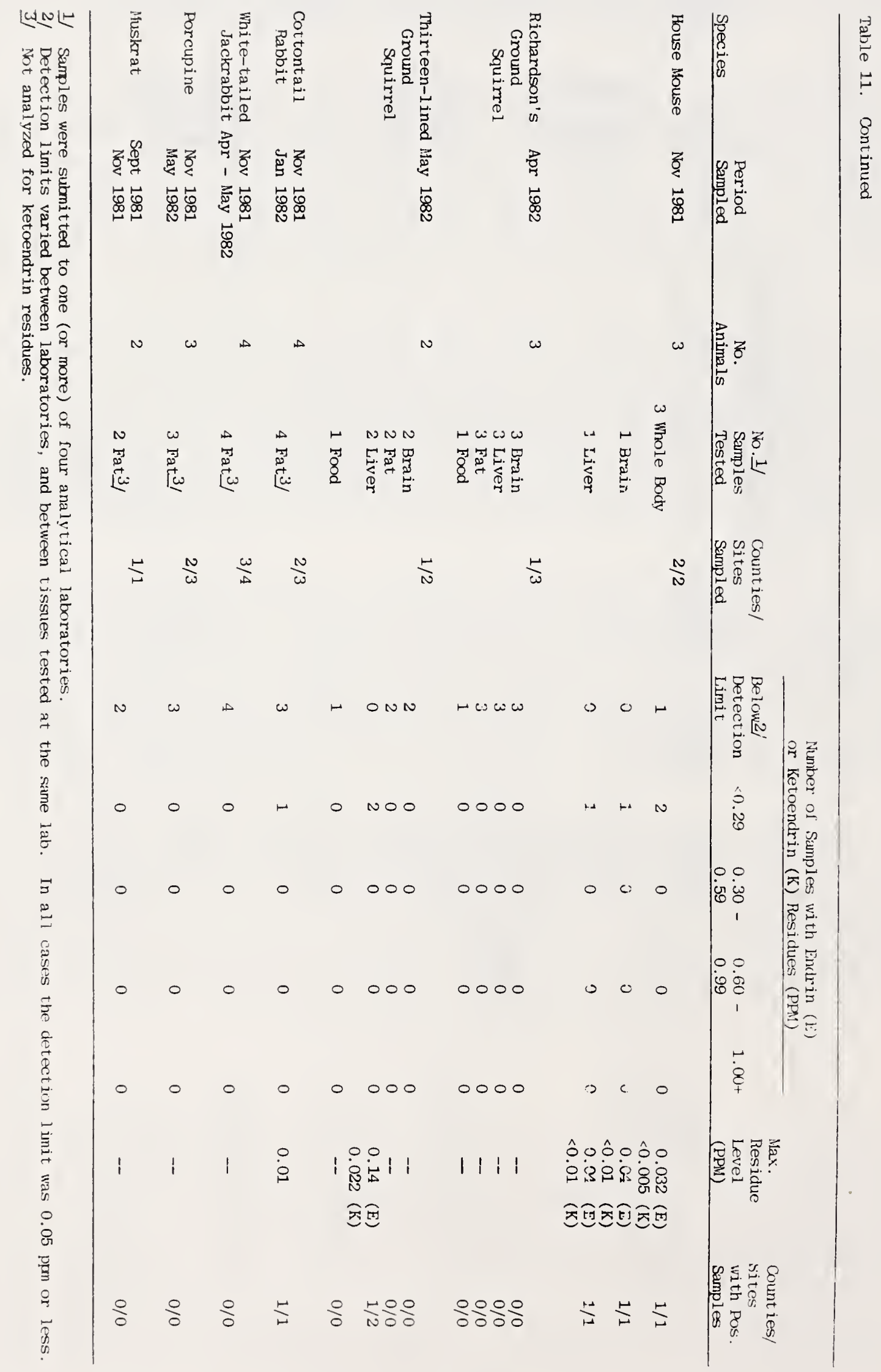


Waterfow 1. Initial collections of waterfowl, in late August 1981, included 8 Canada geese and 1 blue-winged teal, all from Custer county. Results from the first 6 geese collected (range 0.28-0.55 ppm) were near or exceeded the USDA's action level for endrin. After reviewing those results, the same EPA toxicologist consulted about residues in upland birds warned that due to the fatty nature of waterfowl, ADI levels for endrin would be exceeded significantly, and he expressed strong concern for humans eating those waterfowl. Acting upon that expert opinion, the MDFWP immediately expanded its collecting and testing of waterfOWl.

Test results through September 1981 showed that 16 fat samples ( 10 Canada goose and $6 \mathrm{duck}$ ) contained endrin above the USDA action level. A variety of other tissues from those birds were also analyzed for endrin and other contaminants, including samples analyzed following cooking, to see if that process altered residue levels. Both cooked meat and drippings had endrin residues similar to those of raw meat and fat taken from the same bird prior to cooking. This agrees with findings of Ritchey et a1. (1972) who reported that endrin residues were not decreased by cooking. Results of all endrin residue tests on waterfowl through fall 1982 are shown in Table 12.

Since many Montana waterfow 1 hunters and their families eat considerable quantities of waterfowl meat, the highest endrin levels in early samples from each of 5 waterfowl species were used to calculate potential endrin ingestion levels by humans (Appendix G). The ingestion levels were then compared to the ADI for endrin, and indicated that consumption of ducks and geese containing high endrin levels would exceed the ADI, especially if fat was consumed.

The MDFWP again requested opinions of EPA and USDA toxicologists, independent toxicologists, and state health authorities concerning potential hazards to humans eating endrincontaminated waterfowl. Resulting opinions were divided (Appendix H), and the Fish and Game Commission allowed the 1981 waterfowl hunting season to proceed as scheduled, except that the opening of the Canada goose season in 8 southeastern counties was delayed 6 weeks. It was hoped this delay would permit local birds to move south and/or mingle with migrant birds from Canada, thus reducing the probability of hunters getting contaminated birds. The commission also extended the following cautions: remove and discard fat and skin; cook skinned birds on a rack and discard the drippings; do not stuff birds; pregnant and nursing women should not consume waterfowl; and, consumption of waterfowl should be limited to no more than 1 duck or 1 pound of goose meat per week, nor more than 6 ducks or 6 pounds of goose meat per year for adults, and half of this rate for children. Materials emphasizing those cautionary measures were distributed to hunting and fishing license dealers and others throughout the state to be posted in conspicuous places. 


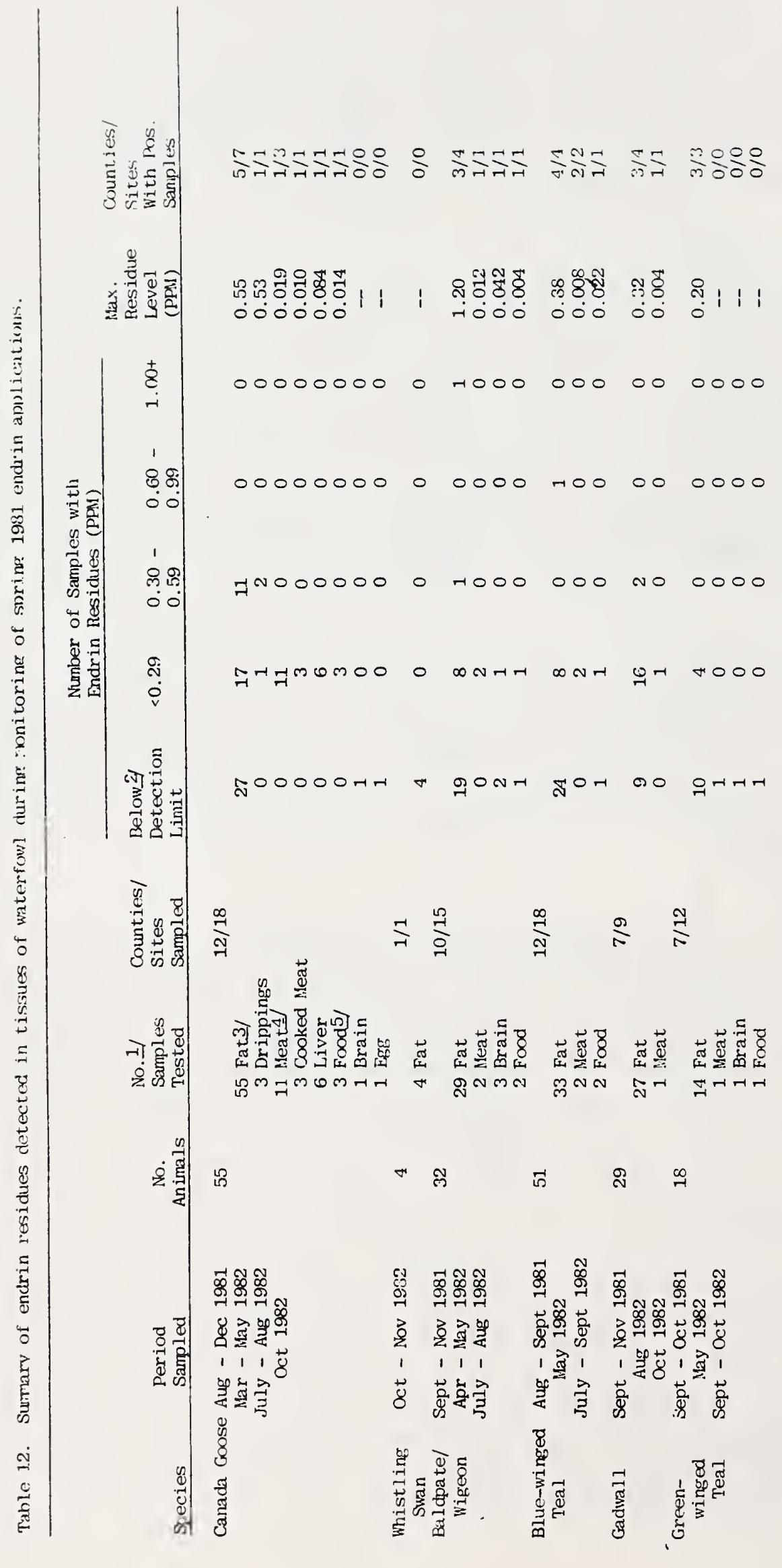




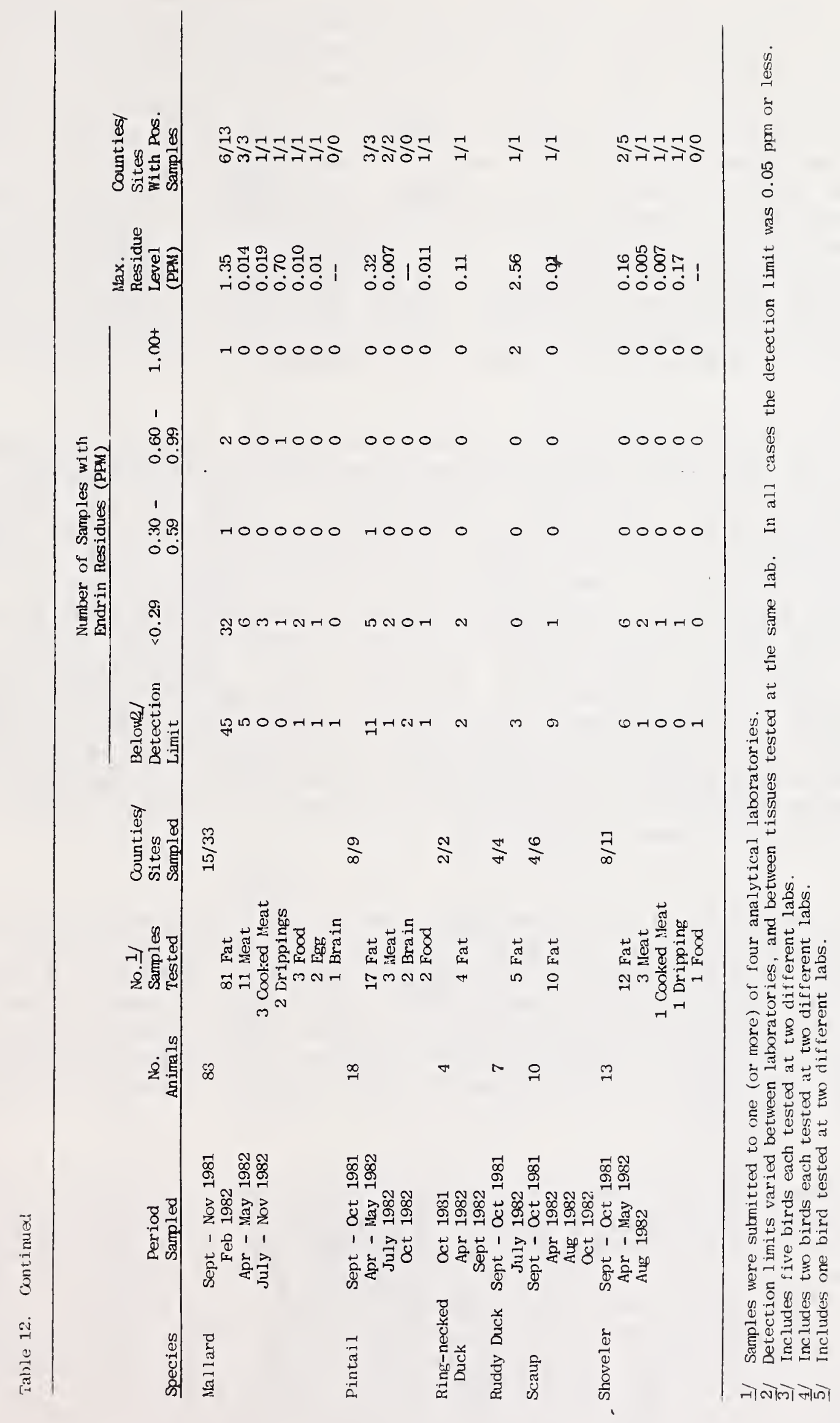


Limited testing of waterfowl was continued through fall 1982. Fat samples of waterfowl collected during spring-fall 1982 included 67 from known 1981 endrin sprayed areas and 62 from other areas. Some of the latter areas were known to be untreated in 1981, while the 1981 spray history of the others was unknown. Seventy-six percent of the fat samples from known 1981 endrintreated areas had detectable endrin residues, while only $16 \%$ of those from other areas were positive for endrin. During the 1982 hunting season, 16 waterfow 1 fat samples were obtained from an area whose 1981 spray history was unknown; 7 of those contained endrin, including one mallard at $0.63 \mathrm{ppm}$ (wet weight). If this area is considered as a probable 1981 endrin treatment site, 95\% of the total spring-fall 1982 waterfowl fat samples that contained endrin were from known or probable 1981 endrin spray areas.

The above data indicated that most 1982 endrin-contaminated waterfowl in Montana were exposed locally, although adult birds may also have been exposed elsewhere. Many of the positive summer 1982 samples came from flightless young, further supporting a hypothesis of local endrin availability. Highest endrin residues (ppm) found in waterfowl fat in spring 1982 were: baldpate, 0.58 ; mallard, 0.32 ; and pintail, 0.32 ; summer and fall samples included Canada goose, 0.13; green-winged teal, 0.20; mallard, 0.63; and ruddy duck, 1.31 and 2.56. These data clearly suggested that individuals of several species of waterfowl contained endrin residues above the USDA action level for well over a year after application, including a few in the second hunting season following spraying. Endrin residues in young Montana ducks in 1982 established its continued presence in aquatic environments more than 1 year postspray.

Other Aquatic Birds and Migratory Game Birds. Limited sampling revealed endrin in 5 of 6 species; only Wilson's snipe lacked detectable endrin in fat samples. Results from all samples (Table 13) showed that many bird species associated with wetlands and agricultural areas treated with endrin contained endrin residues for at least 12-16 months following application. Endrin was available to migratory bird hunters in other states as well as in Montana.

Raptors. The earliest raptor collections from known endrintreated areas included 3 great horned owls taken in November 1981. Other November 1981 raptors sampled ( 1 red-tailed hawk and 1 golden eagle) were sick or injured birds turned in to MDFWP personnel and had no known history of endrin exposure. Horned owls sampled in December 1981 and January 1982, and a kestrel from July 1982 were road kills and also had no known history of endrin exposure. With one exception (a horned owl with 0.01 ppm endrin in its fat), endrin residues were not detected in those samples ( 4 fat and 1 brain) from unsprayed areas. 


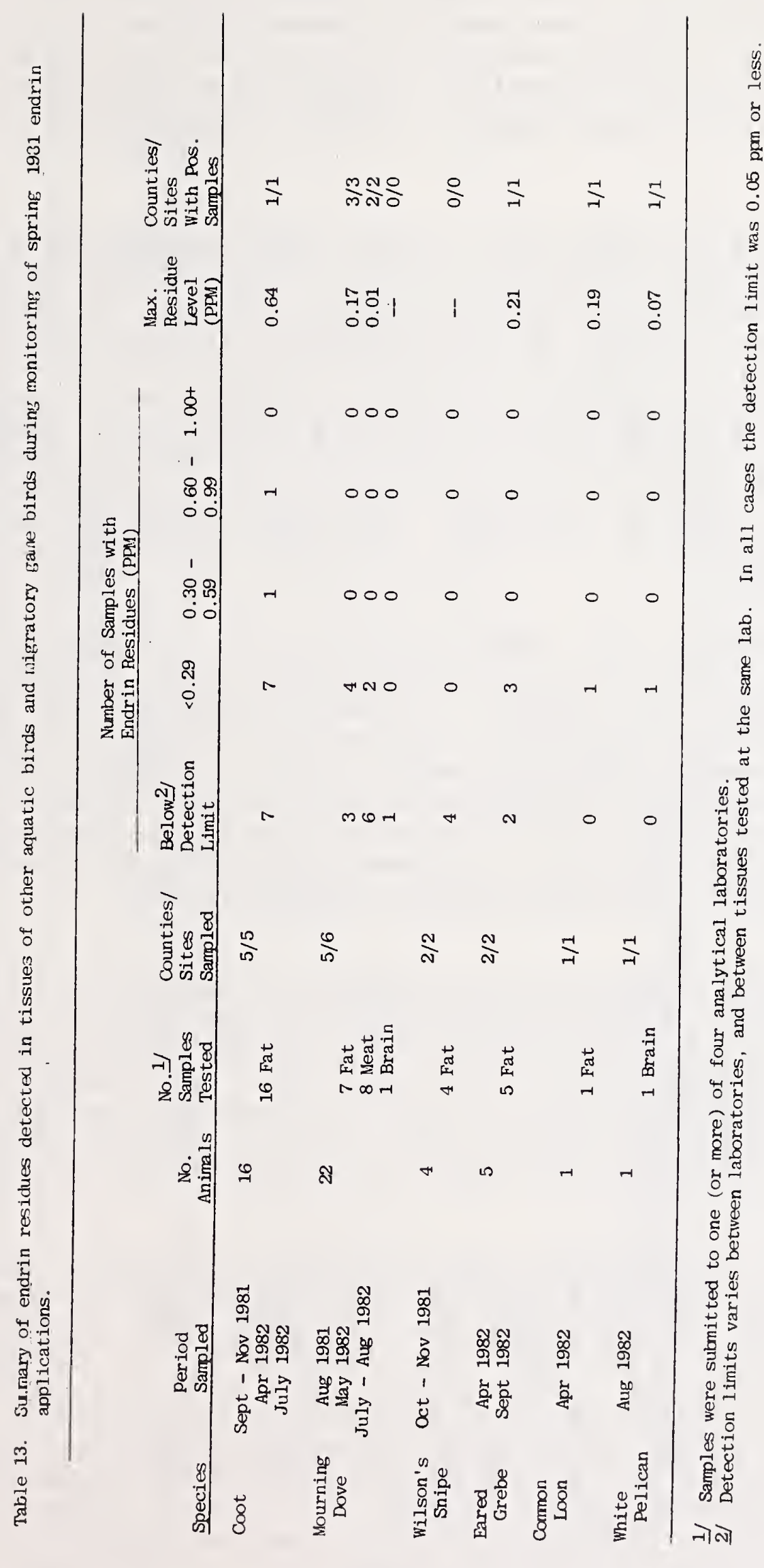


Eight of 10 raptors taken from, or adjacent to, known endrin-treated areas contained endrin residues in their fat (Table 14). Most of those samples were obtained at least 1 year after spraying, and the maximum endrin residue level found was $0.33 \mathrm{ppm}$ in a female harrier. Eggs from this harrier and a long-eared owl ( fat $=0.07 \mathrm{ppm}$ endrin) each contained $<0.01 \mathrm{ppm}$ endrin.

Passerines. The only spring 1981 passerine bird sample tested (a composite fat sample from 1 cowbird and 2 robins) came from an area with no known history of endrin use, and no detectable endrin was found. Three passerine species were collected from 1981 endrin-treated areas in November 1981. However, 2 species (lapland longspur and snow bunting) were migrants which nest far to the north but winter in Montana. Six samples tested from those 2 species were all negative for endrin residues (Table 15). Horned larks were the only locally breeding passerine species to be tested in 1981. Both fat samples, 1 of 2 whole body samples, and 0 of 2 brain samples contained detectable endrin residues.

A small number of samples from each of several breeding passerine species collected in April-May 1982, a full year after endrin spraying, were tested. Several species, including horned lark, white-crowned sparrow, meadowlark, chestnut-collared longspur, and McCown's longspur had 1 or more tissues which tested positive for endrin, although at low levels (Table 15). Those birds, along with the small mammals discussed previously, would provide a source of endrin contaminated food for predators for well over a year following endrin application.

Endangered Species. No evidence of mortality of these species due to 1981 endrin applications was obtained. The rarity of each species in Montana, the lack of timely information about specific treatment sites, and the lack of $t$ issues needed for residue testing (i.e. it was not in the best interest of species welfare to kill individual birds, and no animals dying of other causes were available to test) all contributed to this lack of information.

However, the biology and ecology of whooping cranes, peregrine falcons, and bald eagles indicates that they were potentially subject to exposure by the 1981 endrin applications. Their occurrence in the state and feeding habits strongly suggest that individuals in each species could have been exposed to endrir; the only basic requirement was utilization of endrintreated sites within a month or so after treatment. The species most likely to be exposed would have been the whooping crane, followed by bald eagles peregrine falcons. Recent (1975-1977) documented endrin poisonil of bald eagles (Kaiser et al. 1980) supported the concern expressed for this and other endangered species in Montana. 


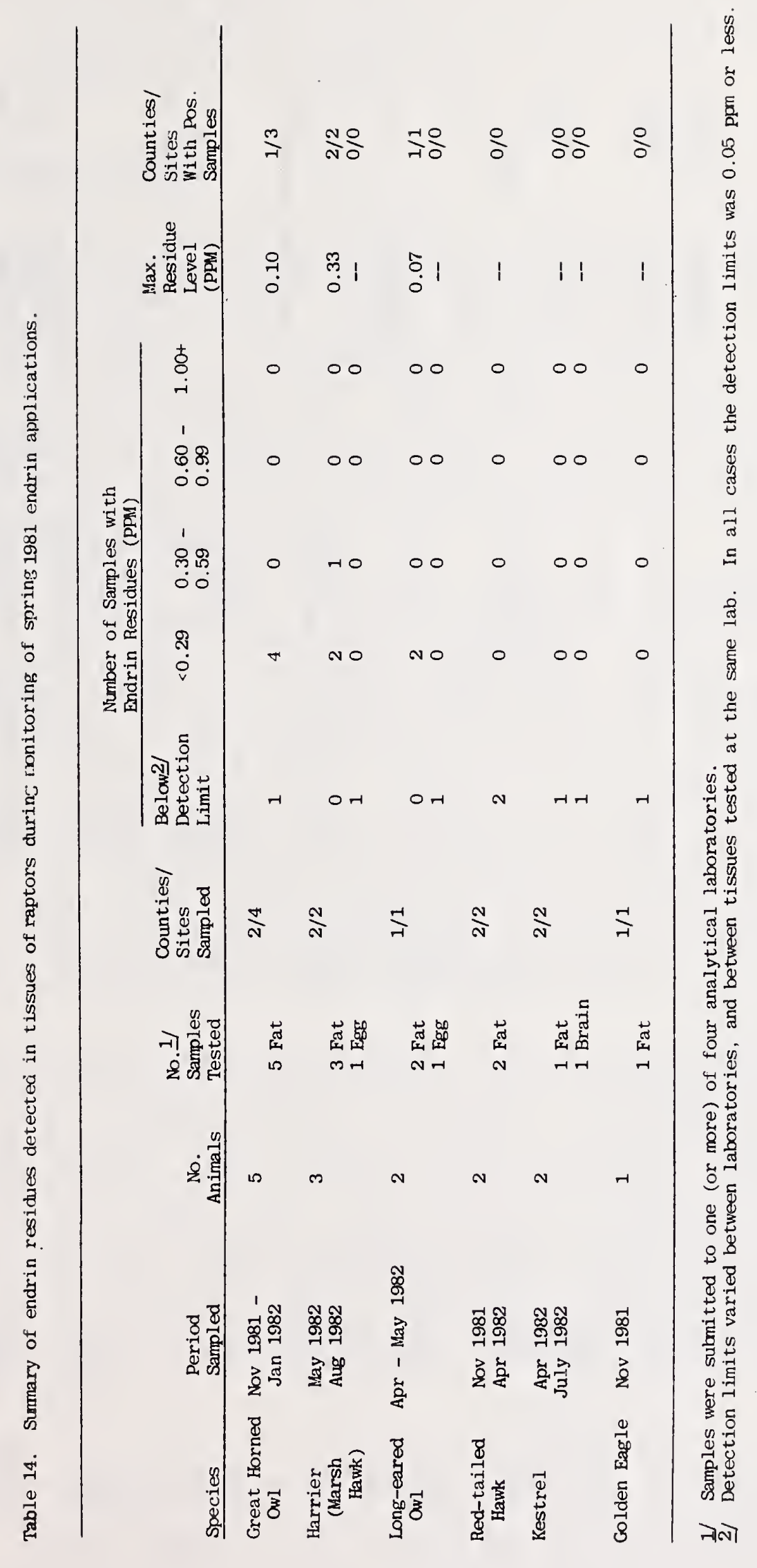




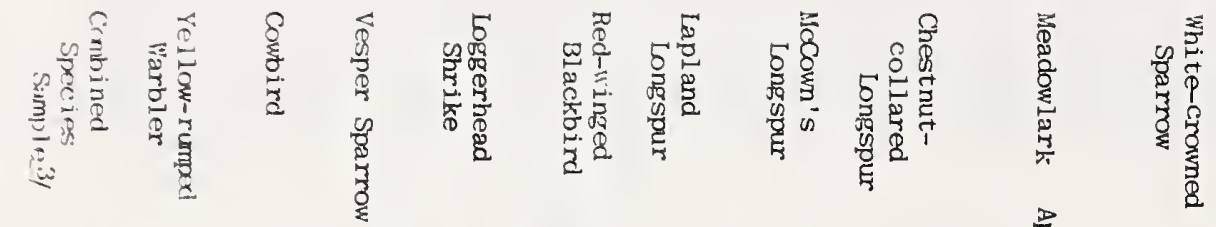

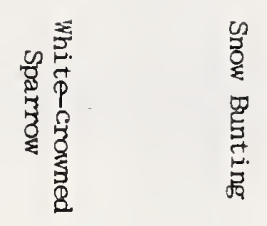

要

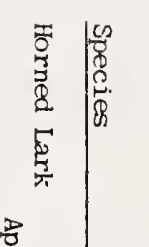

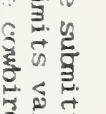

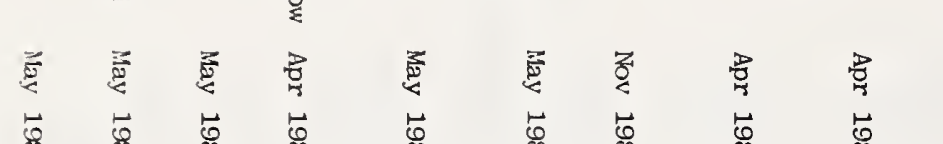

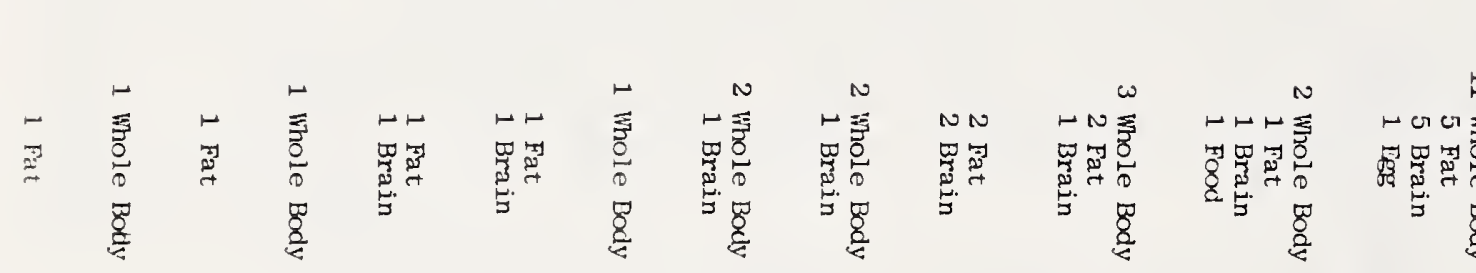
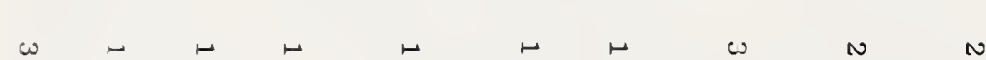

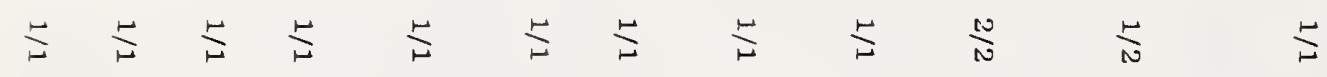
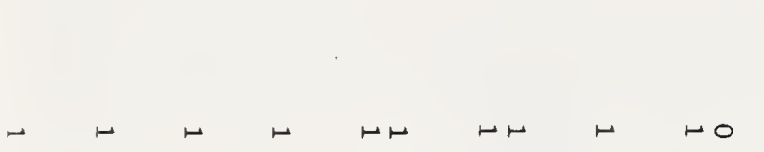

$$
\text { (1) }
$$

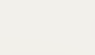$$
\sqrt{3}
$$

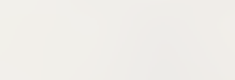

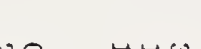$$
(1+r+\infty
$$

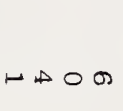

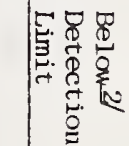

- O O OO OO O ON ON ON OHO OOOO ORGM

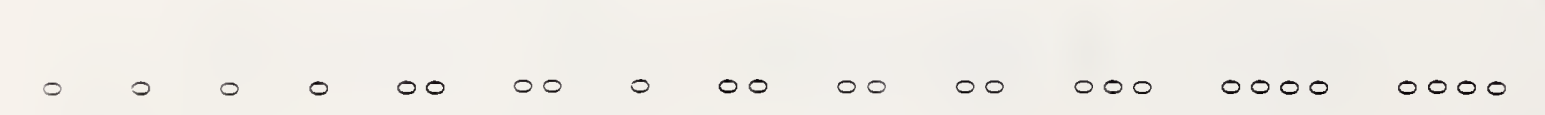

$000000 \quad 00 \quad 0 \quad 00 \quad 000000000000000$

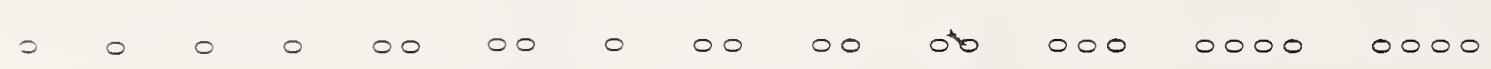

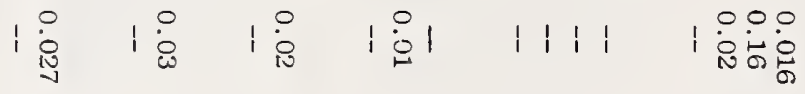

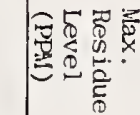

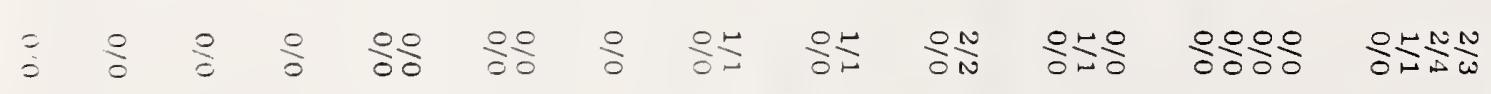


Residue test results indicated widespread endrin contamination of terrestrial wildlife following 1981 endrin spraying. The MDFWP subsequently sampled terrestrial wildife at 151 sites in 26 counties. Positive fat samples were obtained at 46 of these sites in 12 counties (Fig. 15).

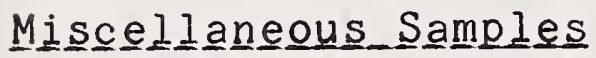

A variety of other samples, mostly related to aquatic habitats, were tested in an attempt to identify sources of contamination for wildlife or test other animals eaten by humans (Table 16). A much larger number of grain, soil, vegetation, and other samples were collected and tested by the MDA. Available data from both MDFWP and MDA suggested 2 possible routes by which waterfowl were contaminated with endrin: living and feeding in contaminated aquatic habitats; and feeding on contaminated grain (including newly growing green shoots) in treated fields. In the latter case, the birds may or may not spend a large part of the day in uncontaminated areas.

Two of the 3 sites at which positive sediment samples were obtained in fall 1981 were sampled again in May and July 1982 and no endrin was found in sediment at that time. Although endrin apparently persists for several months in some pond sediments, it may not persist in that medium as long as it does in some others (eg. soil). Birds collected from one of the ponds (at the same time the July 1982 sediment sample was obtained) had high endrin residues; 2 ruddy ducks had 1.31 and $2.56 \mathrm{ppm}$ in their fat and a juvenile coot had $0.32 \mathrm{ppm}$ in its fat. Those birds were undoubtedly obtaining endrin from the pond environment, probably through eating contaminated aquatic plants and/or invertebrates. Unfortunately none of the latter organisms were tested for endrin so the actual route(s) involved remain unknown.

Because water is not a good indicator of pesticide contamination of ponds only 1 water sample was analyzed. The above data suggest that pond sediments, although retaining residues for some time after exposure, may not be a good indicator of endrin contamination either. This agrees with Keith's (1966, see earlier discussion) findings that where invertebrates are present pesticide residues are largely incorporated into food chains dependent on invertebrates, rather than being deposited with sediments. Future studies should sample sediment, along with submerged aguatic plants and invertebrates, at intervals following exposure to endrin in order to establish the relationships between residue levels in each.

Consumption of Endrin by Wildlife

Due to the lack of informatjon concerrine tinjing and location of endrin appljcatiors, the poteritial for wild ife to consume lethal amounts of endrin was indjrect)y assessed (ste Fig. 13 and Table 17). Actual endrin residues on vegetation from 1981 


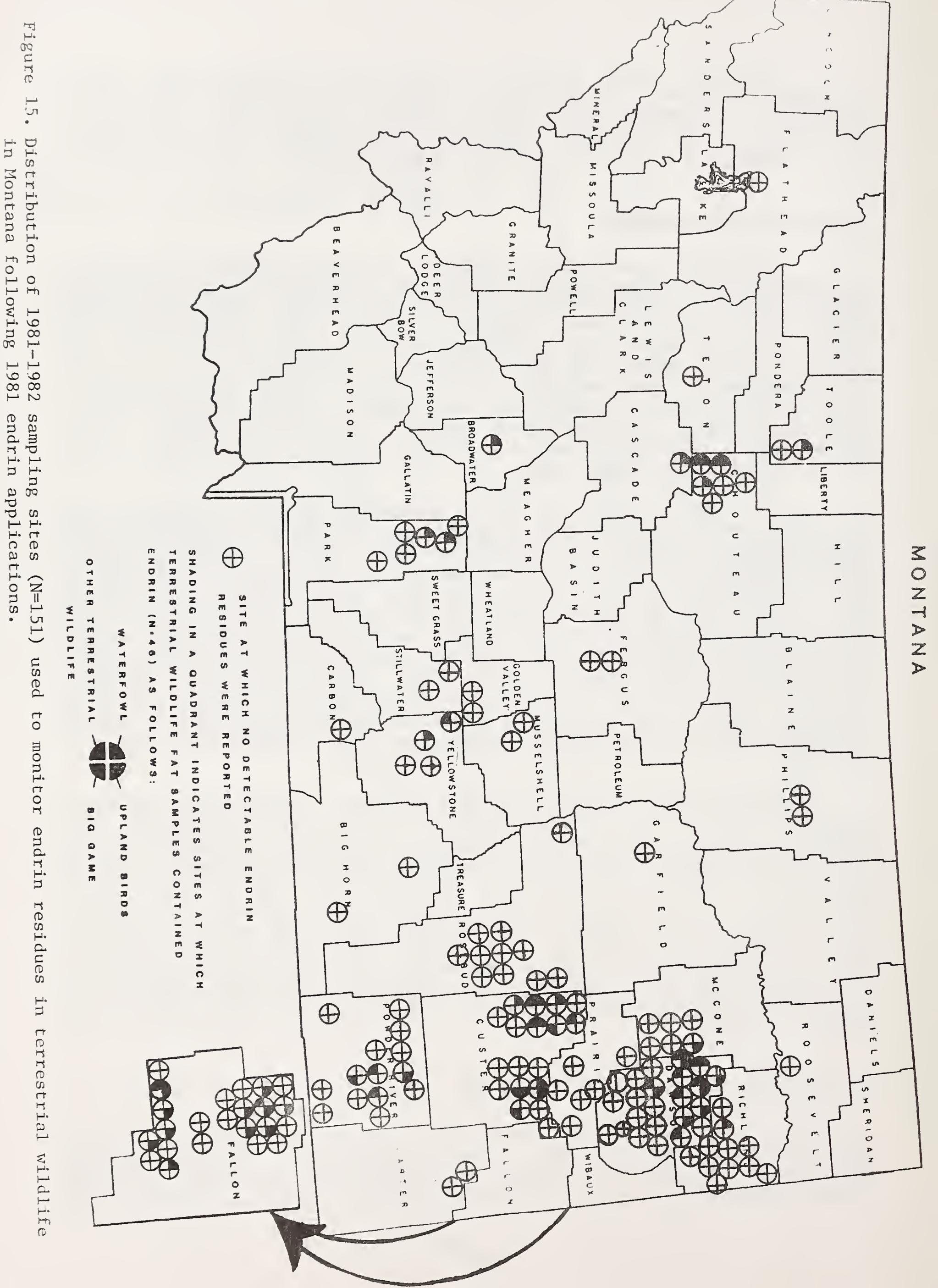




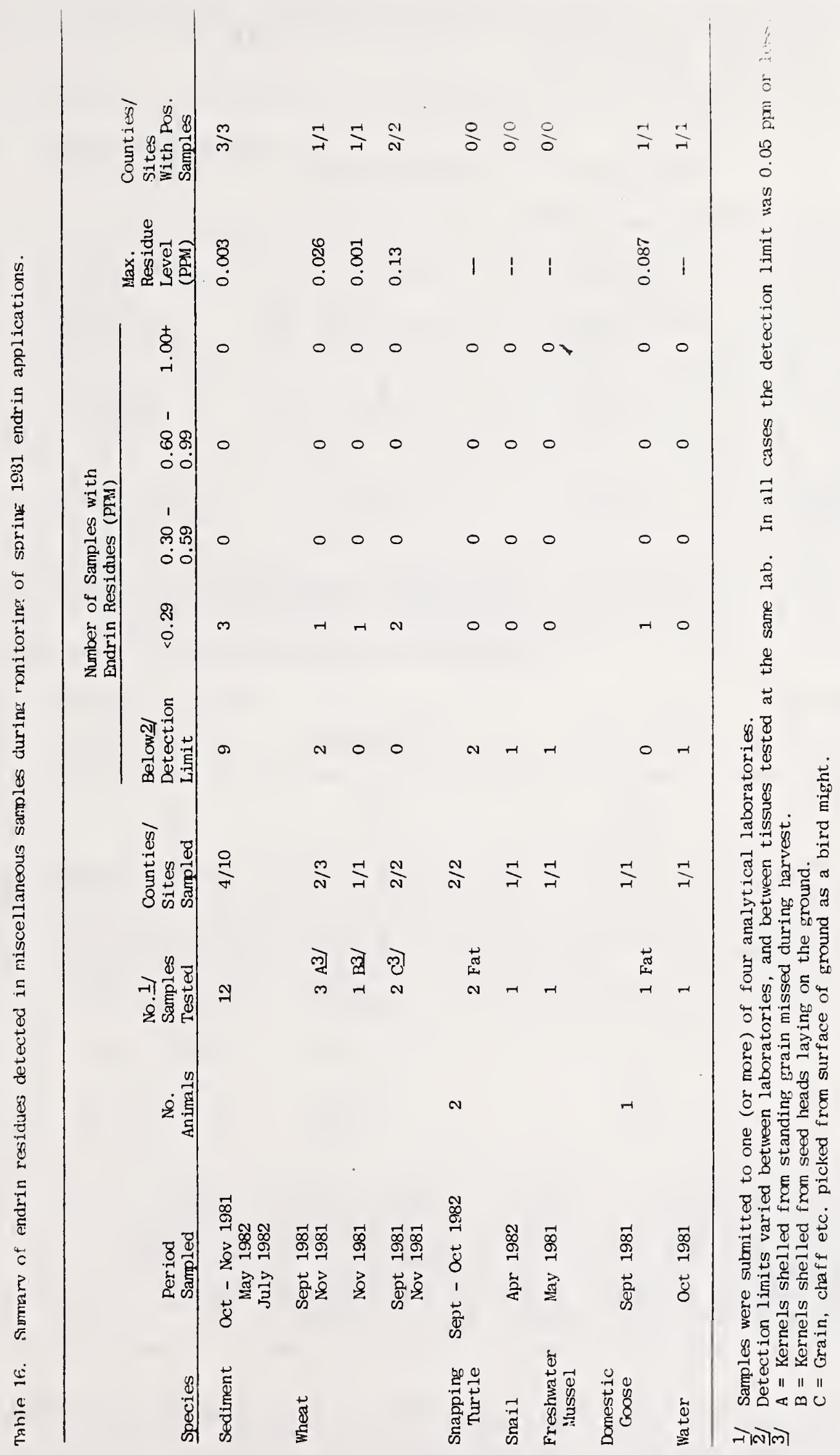


Table 17. Amounts of endrin-contaminated vegetation/food to be ingested to attain Endrin-LD50's in four species of Montana wildife.

\begin{tabular}{|c|c|c|c|c|}
\hline & Mallard & Pheasant & $\begin{array}{l}\text { Sharp-tailed } \\
\text { Grouse }\end{array}$ & $\begin{array}{l}\text { Mule } \\
\text { Deer }\end{array}$ \\
\hline Sex & Female & Female & Female & Female \\
\hline Age & $10-13 \mathrm{mos}$ & $3-4 \operatorname{mos} 1 /$ & 4 yrs & $2-5$ yrs \\
\hline $\begin{aligned} & \text { Body } \text { Wt: } \\
& \text { lbs } \\
& \mathrm{kg}\end{aligned}$ & $\begin{array}{l}2.4 \\
1.09\end{array}$ & $\begin{array}{l}1.5 \\
0.68\end{array}$ & $\begin{array}{l}1.5 \\
0.68\end{array}$ & $\begin{array}{l}125 \\
56.8\end{array}$ \\
\hline \multirow[t]{2}{*}{$\begin{array}{ll}\text { Acute } & \text { Oral } \\
\text { LD } & (\mathrm{mg} / \mathrm{kg})\end{array}$} & 5.64 & 1.78 & $0.75-1.50$ & $6 \cdot 25-12 \cdot 5$ \\
\hline & \multicolumn{4}{|c|}{$\begin{array}{c}\text { Ounces of Endrin-Contaminated Vegetation to be } \\
\text { Ingested to Attain } L D_{50}\end{array}$} \\
\hline $\begin{array}{l}\text { Endrin Content } \\
\qquad(\mathrm{ppm})\end{array}$ & Mallard & Pheasant & $\begin{array}{l}\text { Sharp-tailed } \\
\text { Grouse }\end{array}$ & $\begin{array}{l}\text { Mule } \\
\text { Deer }\end{array}$ \\
\hline 0.4521 & 396 & 95 & $40-80$ & $>1,700^{3 /}$ \\
\hline 2.841 & 77 & $15 \cdot 2$ & $6.4-12.8 * *$ & $279-559$ \\
\hline $8.64 /$ & 25 & $5.0 *$ & $2 \cdot 1-4 \cdot 2 *$ & $91-182$ \\
\hline $17 \cdot 7^{5 /}$ & $12 \cdot 2$ & $2 \cdot 7^{*}$ & $1.0-2.0 \%$ & $44-88$ \\
\hline $18.96 /$ & 11.5 & $2 \cdot 3^{*}$ & $0.95-1.9 *$ & $41-82$ \\
\hline 24.051 & 9.0 & $1.8 *$ & $0.75-1.5 *$ & $33-65$ \\
\hline
\end{tabular}

* Sufficient intake in 1 day to attain the LD 50

* Sufficient intake in 2 days to attain the LD 50

1/ Pheasants this age are approximately adult size

2/ Found in wheat plants 4 weeks postspray (MDA)

3/ Food weights for mule deer are in pounds

4/ Minimum and maximum found in wheat plants 2 weeks postspray (MDA)

5/ Minimum and maximum found in wheat plants 2 days postspray (MDA)

6/ Found in range grass 2 weeks postspray (MDA) 
treatment sites (from MDA sampling) and acute oral toxicities for adult animals of 4 species (Tucker and Crabtree 1970) were used in the assessment. Daily food intake was assumed to be a minimum of 4 oz for adult mallards, pheasants, and sharp-tailed grouse (cf. Keith 1963, Burrage and Saha 1972), and 4 lb (dry weight) for adult mule deer in summer (Wallmo 1981:115).

Sharptails and pheasants could have eaten enough endrincontaminated wheat $(8.6 \mathrm{ppm})$ in 1 or 2 days to have resulted in mortality (Table 17); wheat with endrin residues of this magnitude was available for up to 2 weeks postspray. Mallards could have consumed sufficient highly contaminated wheat (17.7 ppm) during 3 days to result in mortality. Daily ingestion of similar levels $(1.0 \mathrm{mg} / \mathrm{kg})$ of endrin were fatal to most wigeon within 5 days (Keith 1963). Mule deer probably did not eat enough to cause mortality, unless the highest endrin-content food ( 24.0 ppm) was available for several days, in which case it is assumed that 10-12 pounds (fresh weight) is eaten daily. Poisoning deaths of mule and white-tailed deer, antelope, and cattle have occurred following endrin treatment of wheat at the same application rates as recommended for cutworms in Montana (Anonymous 1968, Colorado Department of Agriculture 1968, Hepworth and Roby 1968, Environmental Protection Agency 1980b).

\section{Costs and Consequences of Endrin Usage}

\section{To Wildlife}

Recommended application rates for endrin and the levels of endrin residues found on vegetation, in the contents of bird crops, and in the tissues of pheasants, sharptails, and several waterfowl suggest that wildlife mortalities occurred during the spring of 1981. The extent of those mortalities and the consequences to respective local wildlife populations remain unknown.

\section{To Hunting}

Although other variables (eg. a general economic recession, increased gasoline prices, etc.) could have influenced the purchase of bird hunting licenses, hunter participation, and related expenditures in 1981, most costs and hunter reactions discussed below are attributable to endrin contamination of game meat.

License Sales, Hunter Participation, and Harvests. Game bird hunting license sales in Montana in 1981 were down $15-17 \%$ from previous years (Table 18). Numbers of resident licenses decreased from 1980 to 1981 more than those for nonresidents, probably because residents were exposed to more frequent news reports concerning endrin in game birds (upland as well as waterfowl) within the state. Game bird hunting license sales in 1982 
Table 18. Summary of the numbers of resident and nonresident game bird hunting Iicenses issued in Montana, 19761981 .

License

Year

Resident1/ Non- $\quad$ Resident2/

Total

1976

1977

1978

1979

1980

1981

62,493

67,817

66,951

67,408

67,109

55,482

3,432

65,925

71,017

3,151

3,431

70,102

2,638

70,839

69,747

57,940

1976-1980

Average

66,355

3,170

69,526

\% Change

1980 to 1981

$-17$

$-7$

$-15$

\% Change

Between 5-yr

avg \& 1981

$-16$

$-22$

$-17$

1/ Includes sportsman, bird-adult and bird-youth license.

2/ Includes bird and bird-fish licenses during 1976-1979, but bird license only during 1980-1981.

$(64,930)$ increased $12 \%$ from 1981 but remained $7 \%$ below the $1976-$ 1980 average. Resident and nonresident license sales in 1982 were 61,723 and 3,207 respectively.

Numbers of upland game bird hunters afield in 1981 were 29\% fewer than in the previous 5 years (Table 19). The hunting participation rate by license buyers also declined; the 5-year participation average was $76 \%$ compared to $74 \%$ in 1980 and $65 \%$ in 1981 (from Tables 18 and 19). Hunters hunted $37 \%$ fewer days in 1981 compared to 1980 and $39 \%$ fewer than the 5-year average. The decrease in total upland game birds harvested from 1980 to 1981 (20\%) and from the 5-year average (57\%) also reflected the low participation. Decline in harvests of all $3 \mathrm{major}$ upland bird groups in 1981 suggested that hunters did not differentiate between species that occupied habitats subject to endrin treatments (prairie grouse and farmland exotics) and habitats with little chance of endrin exposure (forest grouse). 
Table 19. Summary of numbers of upland game bird hunters afield, days hunted, and birds harvested in Montana, 1976-1981.

\begin{tabular}{|c|c|c|c|c|c|c|}
\hline \multirow{2}{*}{ Years } & \multirow{2}{*}{$\begin{array}{l}\text { No. upland } 1 \\
\text { Bird Hunters } \\
\text { Afield }\end{array}$} & \multicolumn{4}{|c|}{ Upland Birds Harvested $1 /$} & \multirow[b]{2}{*}{$\begin{array}{l}\text { Days } \\
\text { Hunted }\end{array}$} \\
\hline & & $\begin{array}{l}\text { Prairie } \\
\text { Grouse }\end{array}$ & $\begin{array}{l}\text { Forest } \\
\text { Grouse } 3 /\end{array}$ & $\begin{array}{l}\text { Farmland } \\
\text { Exotics }\end{array}$ & Total & \\
\hline $\begin{array}{l}1976 \\
1977 \\
1978 \\
1979 \\
1980 \\
1981\end{array}$ & $\begin{array}{l}50,597 \\
53,170 \\
51,222 \\
57,313 \\
51,756 \\
37,459\end{array}$ & $\begin{array}{r}188,156 \\
129,938 \\
139,869 \\
188,179 \\
109,813 \\
82,706\end{array}$ & $\begin{array}{r}107,999 \\
131,989 \\
137,340 \\
191,305 \\
75,088 \\
53,817\end{array}$ & $\begin{array}{l}193,242 \\
208,042 \\
197,832 \\
170,886 \\
147,352 \\
129,905\end{array}$ & $\begin{array}{l}489,397 \\
469,969 \\
475,041 \\
550,370 \\
332,253 \\
266,428\end{array}$ & $\begin{array}{l}360,663 \\
363,777 \\
349,314 \\
426,879 \\
354,413 \\
224,707\end{array}$ \\
\hline $\begin{array}{l}\text { 1976-1980 } \\
\text { Average }\end{array}$ & 52,811 & 151,191 & 128,744 & 183,470 & 463,405 & 371,009 \\
\hline $\begin{array}{l}\text { \% Change } \\
1980 \text { to } 1981\end{array}$ & -28 & -25 & -28 & -12 & -20 & -37 \\
\hline $\begin{array}{l}\text { \% Change } \\
\text { Between 5-yr } \\
\text { avg \& } 1981\end{array}$ & -29 & -45 & -58 & -29 & -57 & -39 \\
\hline
\end{tabular}

1/ Numbers given are point estimates obtained from annual wildlife harvest surveys.

2) Includes sage grouse and sharp-tailed grouse.

3/ Includes blue grouse, ruffed grouse, and Franklin's grouse.

4/ Includes pheasant, Hungarian partridge, and chukar partridge.

Numbers of upland game bird hunters afield during 1982 $(36,595)$ approximated those in 1981 , but were $31 \%$ fewer than the 1976-1980 average. They harvested 4\% fewer birds than in 1981 and $45 \%$ fewer than the 1976-1980 average. Harvests of prairie grouse and farmland exotic species declined from 1981 to 1982 ( $15 \%$ and $3 \%$ respectively), while those for forest grouse increased $11 \%$. Hunters spent more time hunting in 1982 than in $1981(+14 \%)$, but $31 \%$ less than the 1976-1980 average.

Waterfowl hunting was impacted more severely than hunting of other species in Montana in 1981. Sales of waterfowl hunting stamps decreased 22-27\% from previous years (Table 20). Participation in hunting declined from a 5 -year average of $79 \%$ to $56 \%$ for duck hunters in Montana and from $56 \%$ to $35 \%$ for goose hunters. Numbers of hunters afield decreased 43-48\% in 1981 from prior years. In 1981, total days hunted dropped $37-49 \%$ and waterfowl harvested decreased 12-40\% from previous years. Numbers of ducks harvested in 1981 decreased $40 \%$, while numbers of geese harvested declined $12 \%$, from the previous 5 year average. 
Table 20. Summary of numbers of federal waterfowl hunting stamps sold, hunters afield, hunter days, and waterfow 1 harvested in Montana, 1976-1981.

\begin{tabular}{|c|c|c|c|c|c|c|c|}
\hline \multirow[t]{2}{*}{ Year } & \multirow[t]{2}{*}{ Stamps } & \multicolumn{2}{|c|}{$\begin{array}{l}\text { No. Hunters } 1 \\
\text { Afield }\end{array}$} & \multicolumn{2}{|c|}{$\begin{array}{c}\text { Tota } 1 \underset{\text { Days }}{1 /} \\
\text { Hunted }\end{array}$} & \multicolumn{2}{|c|}{$\begin{array}{c}\text { No. Waterfow } 11 \\
\text { Harvested }\end{array}$} \\
\hline & & Ducks & Geese & Ducks & Geese & Ducks & $\mathrm{Ge}$ \\
\hline $\begin{array}{l}976 \\
977 \\
978 \\
979 \\
980\end{array}$ & $\begin{array}{l}30,114 \\
29,858 \\
30,401 \\
28,504 \\
27,446 \\
21,336\end{array}$ & $\begin{array}{l}23,680 \\
23,403 \\
21,832 \\
24,868 \\
21,284 \\
12,043\end{array}$ & $\begin{array}{r}13,950 \\
13,597 \\
12,517 \\
14,667 \\
13,976 \\
7,568\end{array}$ & $\begin{array}{r}148,237 \\
140,650 \\
126,625 \\
152,689 \\
157,655 \\
80,091\end{array}$ & $\begin{array}{l}69,750 \\
69,073 \\
69,958 \\
76,268 \\
82,506 \\
46,540\end{array}$ & $\begin{array}{l}215,249 \\
217,023 \\
206,703 \\
245,061 \\
208,153 \\
130,735\end{array}$ & $\begin{array}{l}13,2 \\
14,6 \\
14,2 \\
19,6 \\
17,2 \\
14,0\end{array}$ \\
\hline
\end{tabular}

$1976-1980$

Avg . $\quad 29,265 \quad 23,013 \quad 13,741 \quad 145,171 \quad 73,511 \quad 218,438 \quad 15,872$

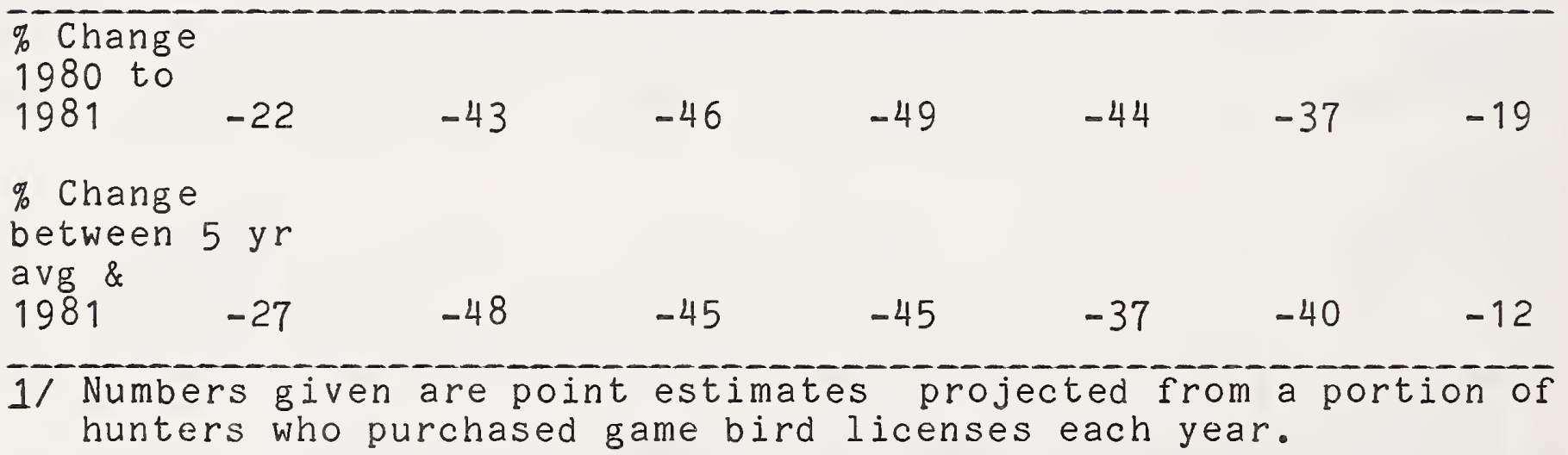

Public Awareness Survey. Most ( $98 \%$ ) of the 162 resident game bird license holders interviewed following 1982 hunting seasons were aware that upland game birds and waterfowl could have been contaminated with pesticides in 1982. Survey results are summarized below; detailed results are in Appendix E.

Major sources of public awareness were newspapers $(73 \%$ of the respondents), television (46\%), and radio (33\%); word of mouth (15\%), license dealers ( $7 \%)$, and other ( $7 \%$ ) comprised the remaining sources of information.

The survey revealed that $73 \%$ of respondents were concerned to some degree about pesticide contamination of upland game birds, while $26 \%$ were not worried at all. Thirty-four percent of the licensees did not hunt upland birds, and $30 \%$ of those made that decision because of pesticide contamination.

The 76 surveyed households consumed an average of 6.7 birds per household. An additional 2.2 birds per household were frozen or otherwise preserved for future consumption. Within those 
households, five women were pregnant or nursing and 1 of each ate upland game birds in 1982.

People in 74 (97\%) of the 76 responding households indicated birds were skinned prior to cooking, $73(96 \%)$ had removed body fat from the birds, 70 ( $92 \%)$ did not eat any dressing/stuffing, and 61 (80\%) stated that drippings from cooked birds were discarded.

Seventy-seven percent of the 157 respondents expressed concern for pesticide contamination of waterfowl. Two-thirds did not hunt waterfowl and $30 \%$ of those made that decision because of the potential presence of pesticides.

The 38 households surveyed consumed and/or had preserved an average of 8.4 ducks and 1.0 goose per household. In those households, three women were pregnant or nursing ( 1 had been pregnant and then was also nursing her baby) and each consumed waterfowl.

People in 27 ( $82 \%$ ) of 33 households who ate waterfowl from 1982 hunting seasons indicated they skinned the birds, 29 ( $87 \%$ ) removed the body fat before cooking, $33(100 \%)$ discarded the stuffing/dressing, and 28 ( $85 \%)$ discarded the drippings after cooking.

The telephone interview survey revealed an extremely high level of hunter awareness of pesticide contamination of game birds in 1982. Most hunters probably became aware of that contamination prior to 1981 hunting seasons, and the survey, following 1982 seasons, may have reflected cumulative or residual awareness from the prior year. Nonetheless, awareness was at a high level in 1982, which will probably continue for the next several years.

Most hunters obtained their information on pesticide contamination from the news media. Informational bulletins by the MDFWP were primarily released in 1981, while the survey contacted hunters 16 months later. Regardless of the source of information, $87 \%$ of the 158 respondents thought they were adequately informed on this issue.

Slightly more concern was expressed for pesticide contamination of waterfowl than upland game birds; that could be due to the delayed opening of the 1981 goose season in southeastern Montana and to the fattier nature of waterfowl flesh compared to that of upland fowl. Although $30 \%$ of the respondents indicated they did not hunt either upland birds or waterfowl because of potential contamination problems, twice as many hunted upland birds in 1982 as hunted waterfowl. Additional other hunters in both groups could have quit hunting altogether in 1981 and/or 1982 because of potential pesticide contamination of birds, and were therefore unavailable for the 1982 surveys. 
Study Costs. The 1981 Endrin Issue in Montana was expensive for the MDFWP because of the direct expenses involved in obtaining and testing wildife tissues for pesticide residues, and compiling and reporting test results. Initial attempts to document endrin residues in wildlife (July-October 1981) cost $\$ 96,192$. The continued endrin monitoring effort through the summer of 1982 cost an additional, estimated $\$ 74,321$. Subsequent field studies of the effects of endrin and 2 alternative insecticides on wildlife, plus the expanded wildlife collections and testing for heptachlor, heptachlor epoxide and other chemical residues resulted in an estimated $\$ 53,158$ in expenses. Final data analyses and report preparation cost about $\$ 38,289$. Total direct expense to the department was a minimum, estimated $\$ 261,960$.

Hunting License Income Losses. Game bird hunting license revenues in 1981 were $\$ 50,190$ less than in $1980(-15 \%)$ and $\$ 81,324$ less than the 1976-1980 annual average (-22\%) (Table 21). Those losses were considered minimums because of a significant increase $(60 \%)$ in numbers of resident sportsmen licenses sold between 1980 and 1981. Because the MDFWP received $\$ 1.96$ from federal aid in wildifife restoration funds for each license sold, the MDFWP lost an additional $\$ 23,142$ from reduced license sales between 1980 and 1981.

Total license revenues in 1982 were $\$ 33,822$ less than the 1976-1980 annual average. An additional $\$ 9,441$ was lost in 1982 due to reduced federal aid matching funds, resulting in a 2-year (1981 and 1982) total revenue loss of $\$ 116,595$.

In addition to the money spent and income lost by the MDFWP, the time devoted to researching and informing others about this issue replaced time and efforts needed to implement the routine wildlife program of the state. No monetary value could be assigned to those lost data and efforts.

Federal waterfowl hunting stamp sales in Montana decreased $22 \%$ between 1980 and 1981 and $27 \%$ from the previous 5-year average to 1981 (Table 20). At $\$ 7.50$ per hunting stamp, the federal government lost $\$ 45,825-\$ 59,467$ in income. The FWS also experienced direct expenditures from this issue through collecting waterfowl in 1981, by testing those and other wildlife tissues for pesticide residues, and by participating in the 1982 field studies in Montana. 
Table 21. Revenues generated by the sale of game bird hunting licenses to the Montana Department of Fish, Wildlife and Parks, 1976-1981.

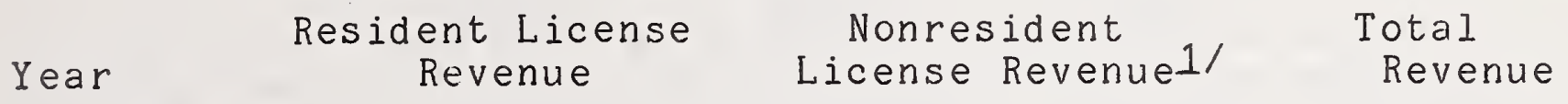

$\begin{array}{lrrr}1976 & \$ 241,056 & \$ 137,320 & \$ 379,385 \\ 1977 & 262,563 & 115,200 & 377,763 \\ 1978 & 259,344 & 114,410 & 373,754 \\ 1979 & 261,468 & 121,950 & 383,418 \\ 1980 & 260,522 & 79,140 & 339,662 \\ 1981 & 215,732 & 73,740 & 289,472\end{array}$

$1976-1980$

Average

$\$ 256,991$

$\$ 113,604$

$\$ 370,796$

Revenue

change 1980

to $1981 \quad-\$ 44,790$

$-\$ 5,400$

$-\$ 50,190$

Revenue change

between 5-yr

avg \& $1981 \quad-\$ 44,159 \quad-\$ 39,864 \quad-\$ 81,324$

1/ Includes the bird (\$30) license, plus the bird-fish license during 1976-1979, but bird license only during 1980-1981.

\section{To Private Enterprise}

Although comments were received from several sporting goods dealers concerning reduced sales of firearms and ammunition in 1981, no attempt was made to survey those dealers about monetary losses. Phillips (1981) estimated that daily hunter expenditures (excluding license costs) for upland game bird (excluding turkey) and waterfowl hunting in wyoming were $\$ 32.32$ for residents and $\$ 53.71$ for nonresidents in 1980. Utilizing that value for reduced resident hunter days in Montana, private enterprise lost a projected $\$ 3.0$ million from waterfowlers plus $\$ 4.7$ million from upland game bird hunters in 1981. If nonresident hunters had been included, the total loss would have exceeded \$8 million. A majority of this economic loss was borne by merchants in the eastern two-thirds of Montana.

\section{To Agriculture}

Although this subject will be addressed in detail by the MDA, a preliminary evaluation of the economic benefits, and costs, to Montana's agricultural community is presented. In this 
discussion we recognize that individual growers may be severely impacted and will bear the entire financial loss due to cutworm outbreaks in their grainfields.

The 1981 wheat crop in Montana was valued at $\$ 637.5$ million (Table 22). The projected value for the yield from the estimated minimum 98, 848 acres treated with endrin that year, assuming the entire acreage was winter wheat and the yield from that acreage would have been totally eliminated by cutworms (yields are usually not reduced to this extent), was slightly more than $\$ 12.6$ miliion. The estimated yield value from the maximum estimated 123,560 acres treated with endrin, and the same assumptions, would have been about $\$ 15.8$ million. Those estimates represented $4-5 \%$ of the value of the winter wheat crop in Montana in 1981 and $2-2.5 \%$ of the value of the total wheat crop. The inclusion of livestock and other crop yields would have further reduced the percentage of Montana's agricultural economy that was impacted.

Other costs incurred by farmers and ranchers included the loss of livestock grazing in stubble fields which had been treated with endrin. Although endrin label restrictions include prohibitions against such grazing, as well as feeding threshings from treated fields to livestock, many farmers and ranchers in southeastern Montana expressed concern about those regulations. Because endrin residues have been found on vegetation for more than 1 year postspray (O.G. Bain, pers. comm.), the MDA recommends no livestock grazing of stubble fields for a minimum of 1 year after endrin treatment.

Many rural landowners have stock ponds which also host warmwater and trout fisheries, thereby providing recreation and food to farmers, ranchers, their friends, and the general public. When such ponds are privately owned, the buffer zone restrictions for endrin application do not apply and endrin could have been applied to pond edges, or even to pond surfaces, causing losses of aquatic species.

Other subtle, or indirect, costs nay be borne by farmers and ranchers. Broad-spectrum insecticides, like endrin, applied to control one pest species also kill other insects, including beneficial species such as bees, and parasites and predators. In time the effects of the insecticide subside and populations of predators do not recover as rapidly as those of the pest species (ICIATI 1977 in Pimentel and Edwards 1982). This sets the stage for another potential pest species outbreak.

Application of certain chlorinated hydrocarbon insecticides can result in increased nutrient loads in plants (Cole et al. 1968). While this may appear beneficial to the farmer, elevated nutrient levels attract additional insect species, the females of which may lay even nore eggs than normal (Oka and Pimentel 1974). Thus, females of potential pest species are aided in reproductive efforts, to the detriment of the farmer. 
Table 22. Summary of wheat acreages, yields, price per bushel, and crop value in Montana, 1981.

\begin{tabular}{lcccc} 
& $\begin{array}{l}\text { Winter } \\
\text { Wheat }\end{array}$ & $\begin{array}{l}\text { Spring } \\
\text { Wheat }\end{array}$ & $\begin{array}{l}\text { Durum } \\
\text { Wheat }\end{array}$ & Totals \\
\hline $\begin{array}{l}\text { No. Acres } \\
\text { Planted }\end{array}$ & $2,700,000$ & $2,850,000$ & 490,000 & $6,040,000$ \\
$\begin{array}{l}\text { No. Acres } \\
\text { Harvested }\end{array}$ & $2,550,000$ & $2,790,000$ & 480,000 & $5,820,000$ \\
$\begin{array}{l}\text { Avg. Yield Per } \\
\text { Acre (bu) }\end{array}$ & 35 & 26 & 23 & 29.7 \\
$\begin{array}{l}\text { Total Yield } \\
\text { (bu) }\end{array}$ & $89,250,000$ & $72,540,000$ & $11,040,000$ & $172,830,000$ \\
$\begin{array}{l}\text { Avg. Price } \\
\text { Crop Value }\end{array}$ & $\$ 325,762,500$ & $\$ 272,025,000$ & $\$ 39,744,000$ & $\$ 637,531,500$ \\
\hline
\end{tabular}

1/ From Montana Crop and Livestock Reporting Service 1982.

The sum total of these and other relationships can be included in the broad problem of pesticide stress on farm and range lands (Pimentel and Edwards 1982). All of those relationships must be considered when evaluating the true costs and benefits of pesticide usage by Montana's farmers and ranchers.

\section{Absence of Wildlife Carcasses}

The public, and especially agriculturalists, often commented on the apparent absence of wildlife carcasses in or near endrintreated fields in 1981; that absence was interpreted by some to mean that endrin applications resulted in little or no mortality of wildlife. Several factors, individually or collectively, contributed to that impression:

(1) an inadequate pesticide reporting system in 1981 precluded the MDFWP from conducting searches for carcasses when they would have been apparent (i.e. 3-14 days following treatment);

(2) intoxicated or sick animals may seek dense cover in which to hide;

(3) carcasses of small birds and mammals do not remain intact under natural conditions for more than a few days 
(i.e. they are consumed or carried off by predators and scavengers, Rosene and Lay 1963);

(4) carcasses, except those of larger birds and mammals, may go unnoticed; this would be especially true for young birds and mammals in their nests;

(5) unless observers suspect pesticide poisoning, the cause of death of occasional wildlife found might be incorrectly attributed to parasites, diseases, accidents, etc;

(6) rodents and predatory mammals and birds are commonly viewed as pests by agriculturalists; deaths of those species would generally not be reported to a wild ife agency.

Those reasons for lack of wild life carcasses being found following endrin applications are generally supported by the Environmental Protection Agency (1978). In discussing the impacts of endrin on endangered species (eg. brown pelican), the Environmental Protection Agency (1978:35) rejected Velsicol's rebuttal that a pelican die-off was a "small, isolated, and onetimell occurrence. The EPA contended that the odds of finding a dead brown pelican in the wild were remote, and that the lack of such observations over a 3-year period were not grounds to conclude that additional deaths had not occurred.

Wildife biologists, hunters, and farmers would be most likely to observe the direct and indirect effects of endrin applications via drastic, or even subtle but prolonged, declines in resident upland game bird populations. However, without knowledge of locations and timing of endrin treatments, and without verification of endrin residues in those species, population declines could be attributed to a variety of other causes (eg. overhunting, predation). Because economically damaging populations of cutworms occur in Montana wheat fields every 2-3 years (Environmental Protection Agency 1978:26), farmland game birds, including waterfowl, have been exposed to endrin with considerable frequency.

\section{Continued Registration of Endrin by the EPA}

Montanans also voiced concern about the relationship of the 27-year history of endrin use in the state vs. the "sudden" concern for endrin in 1981. Part of the answer lies in the dependency of the MDFWP on prompt, voluntary reports by private citizens about fish or wildlife die-offs. Initial field investigations in the 1981 Endrin Issue were prompted by such a report of a fish die-off in Sunday Creek (Custer County) in March 1981. However, most insecticides are applied when the general public and hunters are not recreating on farm and range lands; fishermen are afield but unless fish mortality is obvious at fishing sites, they have no apparent reason for concern. 
The Environmental Protection Agency (1978:19) indicated similar problems in reporting incidents involving pesticides and wildlife. Their nationwide Pesticide Episode Reporting System (PERS) reports are incomplete for 2 reasons: it "relies on voluntary reporting by private parties to either state agencies or to the EPA concerning pesticide-related kills", and "it does not include all of the incidents which are reported at the state level." The EPA expects "only a nominal amount of the total numbers of incidents...to be both observed and reported to either state or federal authorities." Thus, when private citizens do not report wildlife casualty incidents, no record exists for it, and no cumulative record can be evaluated periodically for potential problems.

In its Rebuttable Presumption Against Registration (RPAR) of endrin during the late 1970's, the EPA recognized some of the hazards of endrin to wildlife and people who eat wildlife (Environmental Protection Agency 1978). The following are examples of specific concerns:

(1) The EPA admitted (P. 60), "there is some risk to bald eagles which may be poisoned by consuming moribund and dead fish associated with the use on small grains."

(2) They stated (Pp. 138-139), "...several State registrations for grasshopper control on wheat and non-crop land were received by the Agency in 1978. Velsicol's labels for these new registrations impose 1/4-mile distance restrictions from bodies of water and habitation for humans and domestic animals. Such restrictions virtually preclude excessive human exposure, but the Agency is concerned with possible hazards to wildlife that may consume contaminated insects and with residues that may exist in game birds consumed by humans.m (emphasis added by current authors).

In its conclusions (P.145), however, the EPA stated, "Private ponds are intentionally excluded from the [1/4-mile] restriction but are to be protected by the label precaution 'Application within 200 yards of ponds may result in fish kills.' "In the EPA's opinion, growers should have the option of choosing between fish and wheat when both are owned by the same individual.

In Montana, however, the fish are not necessarily "owned" by the property owner. Many fish ponds (i.e reservoirs) on private property are stocked with fish reared in MDFWP and FWS hatcheries; i.e. public funds are used to breed and rear the fish for those ponds. Killing those fish with endrin negates any intended public or private benefits from expenditure of those public funds. While private landowners reserve the right to spray or not spray endrin over their ponds, the fish are public property and the public has the right to fish those ponds. If the landowner elects to spray endrin on or within $0.25 \mathrm{mi}$ of the pond, or if fish die from endrin application, the pond must be posted 
against all fishing for a minimum of 6 months (12 months if a fish kill results) (Appendix C). Anyone catching and eating endrin-contaminated $f i s h$ is exposed to any inherent health hazards; the EPA recognized that endrin residues in fish could pose teratogenic risks to humans. Further, terrestrial wildlife (eg. waterfowl, upland game birds), which are also public resources, have been shown by our studies to assimilate endrin applied to small grain fields. They probably obtained the endrin by eating invertebrates and vegetation in and/or near such ponds. Resulting endrin residues in their tissues are available to people eating those species.

One aspect of wildlife biology omitted from the endrin-RPAR process was the critical role of insects, including cutworms and grasshoppers, in the food habits of game and nongame birds. Cutworms were found in the crop of a sharp-tailed grouse in the current studies and insects generally are significant components in the diets of pheasants (Weigand and Janson 1976), Hungarian partridge (Weigand 1980), sharptails (Yde 1977), sage grouse (Wallestad 1975), Merriam's turkey (Jonas 1966), a variety of ducks and geese (Bellrose 1976), and passerine birds (Feist 1968, Best 1970). In fact, Janda (1959) in central Bohemia reported that insects comprised $80-95 \%$ of Hungarian partridge chick diets during their first 3 weeks of life. As a corollary to this finding, Potts (1970) in Great Britain found that partridge chicks died when deprived of insects in their diets. Although the EPA's final action on endrin was to cancel its use for control of all small grain insect pests other than army and pale western cutworms in all states, and grasshoppers in Montana only, endrin is a broad spectrum insecticide and its use on grain fields poses a direct threat to the welfare of birds inhabiting those fields.

1982 Alternative Insecticide-Wildlife Study

The use of alternative methods of cutworm control received increased attention after the 1981 Endrin Issue. Because of endrin's persistence in the environment and its toxicity to fish and wildiffe, the use of such alternative methods of cutworm control has been encouraged. Alternative methods might include changes in farming practices which incorporate non-chemical procedures as well as the use of other, less hazardous insecticides. At least 9 potential alternative cutworm insecticides which are less toxic than endrin to wildlife exist (Table 23). Of these, acephate, carbaryl, fenvalerate, and permethrin seem to be the least toxic to terrestrial wildlife; acephate, carbaryl, dylox, and lannate are the least toxic to fish. 


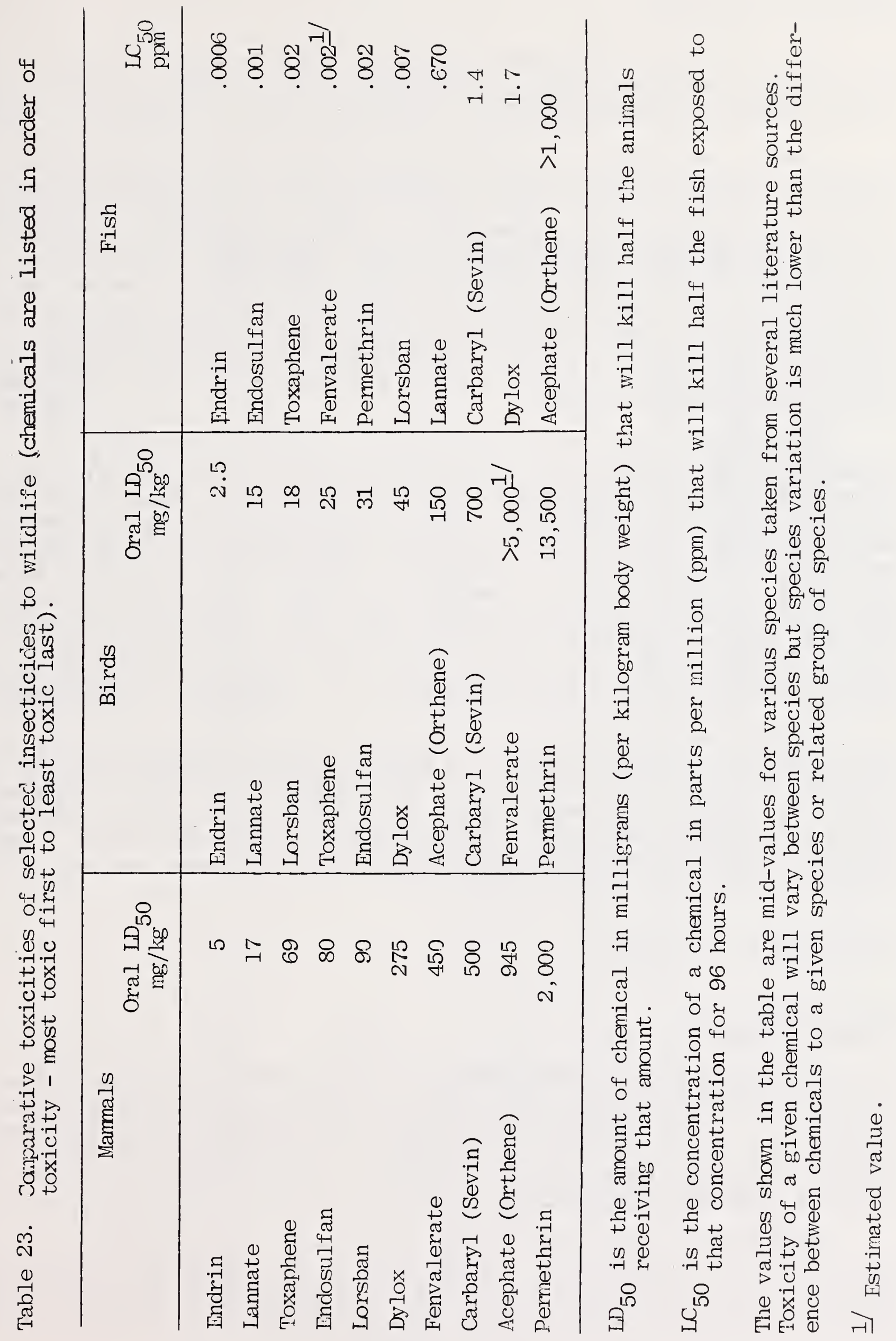


No attempt was made to calculate LC 50 's for the field bioassays because test organisms were dead in all of the treatments after 24 hours.

Under prevailing test conditions endrin was lethal 'co daphnia within 2 hours for at least 1,185 feet downwind from the test plot (Table 24). The endrin label stipulates that application sites must be at least $0.25 \mathrm{mi}(1,320 \mathrm{ft})$ from public waters that support fish life. These findings illustrated that endrin can drift considerable distances downwind from an application site and have a toxic influence even where correct application procedures were followed and wind conditions were within recommended limits. Our results suggested that endrin label requirements do not ensure protection of organisms in waters near spray areas.

Permethrin was also toxic for a considerable distance downwind from the spray area, but mortalities occurred more slowly than with endrin (Table 24). Wind velocity was much lower during the permethrin application, and pesticidedrift was expectedly more limited. Lower air and water temperatures during that early morning application may have been responsible for the delayed toxicity. Rapid diurnal changes in water temperature during the 24-hour period following these tests were probably stressful to the organisms and may have contributed to mortalities. Field tests of this kind do not offer the opportunities for controlling test conditions that are available in a laboratory environment.

These results do not necessarily indicate that the toxic influence of endrin extends a greater distance downwind than that of permethrin. Permethrin is also known to have a high acute toxicity to aquatic organisms. Moreover, test conditions during endrin spraying were more favorable for pesticide drift. Nevertheless, results indicated that label requirements do not protect aquatic life under all conditions.

Terrestrial Surveys

\section{Endrin Studies}

The time between selection of the endrin treatment area and actual application did not allow prespray wildlife populatjon studies. A few ducks and horned larks were collected before spraying and tested for chlorinated hydrocarbon residues. All prespray birds tested had little or no endrin present in the samples tested (Table 25).

Because we were advised not, to enter endrin-treated fields for the first few days following spraying, searches for potential mortalities in treated fields were not conducted until 3 days following application. A deer mouse suspected of being affected 
Table 24. Results of field bioassays using Daphnia magna to monitor drift of aerially applied endrin and permethrin.

\begin{tabular}{|c|c|c|c|c|c|c|c|}
\hline \multirow[t]{2}{*}{ Chemical } & \multirow{2}{*}{$\begin{array}{l}\text { Distance downwind } \\
\text { from plot } \\
\text { (ft) }\end{array}$} & \multicolumn{6}{|c|}{$\begin{array}{l}\text { Percent mortality at various } \\
\text { time intervals after spraying }\end{array}$} \\
\hline & & $\overline{\mathrm{Oh}}$ & $1 \mathrm{~h}$ & $2 h$ & $4 h$ & $6 h$ & $24 \mathrm{~h}$ \\
\hline \multirow{10}{*}{$\begin{array}{l}\text { Permethrin } \\
\text { (ambush) }\end{array}$} & in plot & 0 & - & 0 & 0 & 50 & 100 \\
\hline & 10 & 0 & - & 0 & 0 & 50 & 100 \\
\hline & 35 & 0 & - & 0 & 0 & 90 & 100 \\
\hline & 85 & 0 & - & 0 & 0 & 20 & 100 \\
\hline & 185 & 0 & - & 0 & 0 & 10 & 100 \\
\hline & 385 & 0 & - & 0 & 0 & 40 & 100 \\
\hline & 585 & 0 & - & 0 & 0 & 10 & 100 \\
\hline & 785 & 0 & - & 0 & 0 & 20 & 100 \\
\hline & 985 & 0 & - & 10 & 10 & 10 & 100 \\
\hline & 1185 & 0 & - & 0 & 0 & 0 & 100 \\
\hline
\end{tabular}

\begin{tabular}{ccccc}
\hline Endrin plot & 0 & 100 & 100 \\
10 & 0 & 100 & 100 \\
35 & 0 & 100 & 100 \\
85 & 0 & 100 & 100 \\
185 & 0 & 100 & 100 \\
385 & 0 & 100 & 100 \\
585 & 0 & 80 & 100 \\
785 & 0 & 80 & 100 \\
985 & 0 & 90 & 100 \\
1185 & 0 & 70 & 100 \\
\hline
\end{tabular}




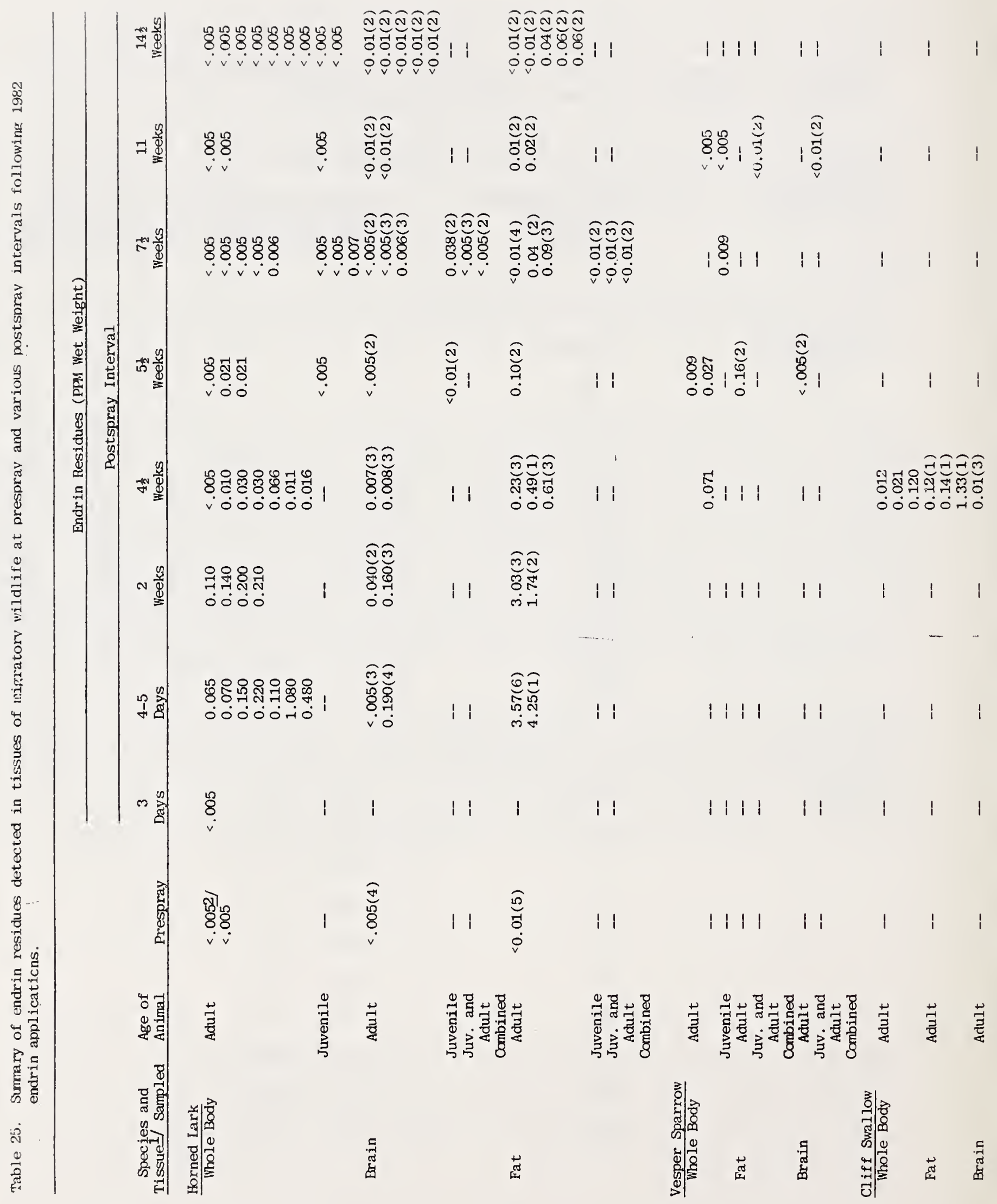




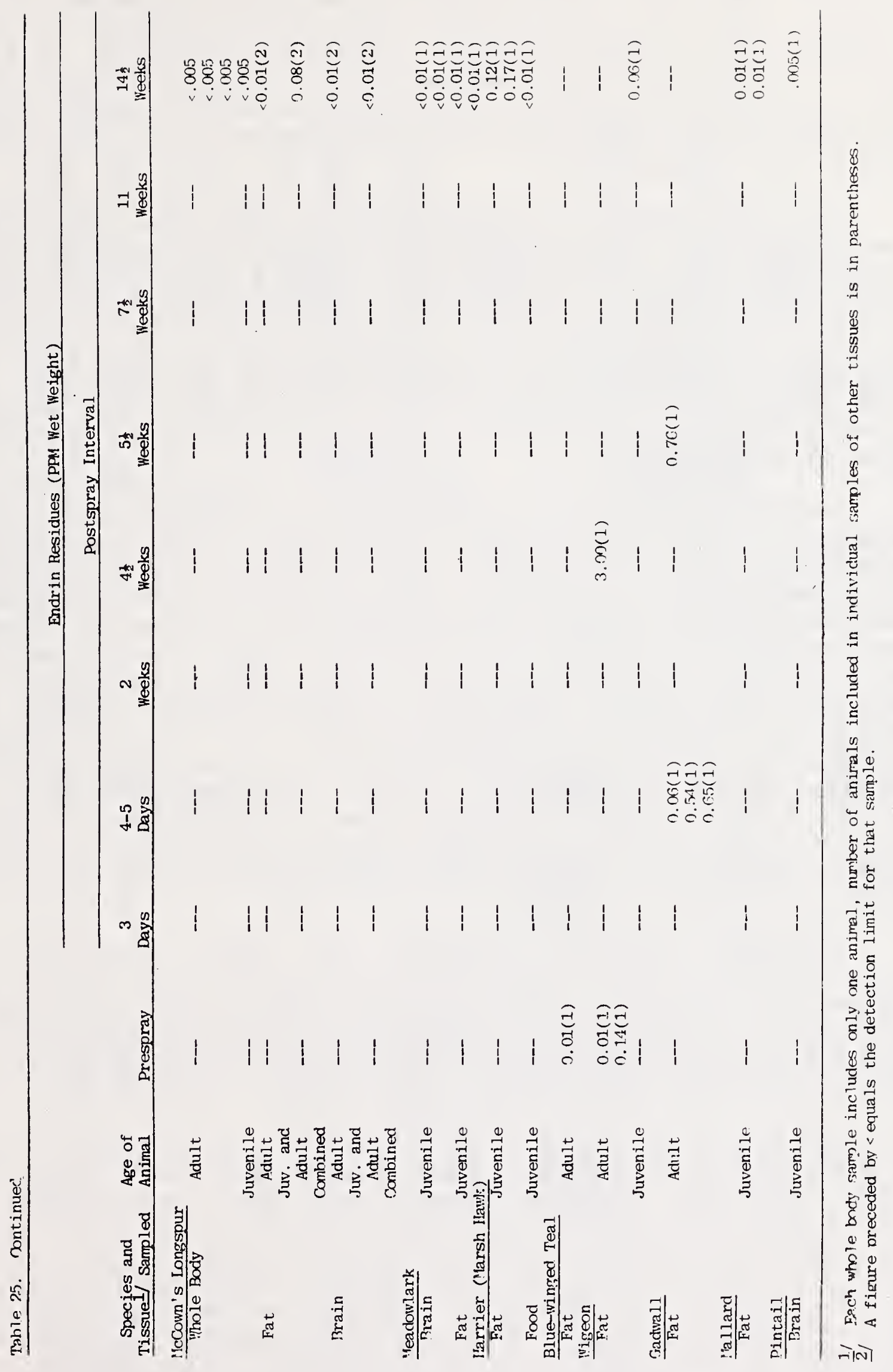


by endrin was hand caught on the day following endrin application during a search for bird nests immediately adjacent to a treated field. Two dead deer mice were found during searches of a treated field on the third day following spraying. A dead horned lark was found by MDA personnel in a treated field on this same day. A black-tailed prairie dog was hand caught 4 days after spraying on the edge of an endrin-treated field which contained a small prairie dog town.

Two bird species (burrowing owl, Speotyto cunicularia, and mountain plover, Eupoda montana) normally associated with prairie dog towns and listed as being species of special interest or concern in Montana (Flath 1981), were seen in this prairie dog town 4 days after spraying. No subsequent observations of these species occurred on or near this prairie dog town, despite considerable time spent there collecting prairie dogs and small bird specimens for residue testing. Whether that absence indicated poisoning deaths of those species or emigration from the area is unknown.

A dead skunk was found on a trail adjacent to an endrintreated field 2 weeks after spraying; it was not there 10 days previously, but was too decomposed to provide suitable material for sampling or assessing the cause of death. Searches of endrin-treated fields on this same date revealed no other sick or dead animals, although 2 sites where small birds had been eaten were found. Field notes from this date indicate that bird activity was notably reduced in endrin-treated fields when compared to adjacent untreated areas or fields treated with permethrin or chlorpyrifos. Three live deer mice were noted in endrin-treated fields during these searches. Similarly, McEwen et al. (1972) found no significant differences in numbers of birds for the first 12-14 days postspray; during 2-7 weeks postspray, however, a significant $(p<0.01)$ decrease in birds around sprayed fields was noted.

Resident wildife tested for endrin residues were deer mouse, black-tailed prairie dog, white-tailed jackrabbit, and cottontail rabbit. Most were tested for both endrin and 12ketoendrin in addition to other chlorinated hydrocarbons. Most residue levels presented from here on are reported as ppm on a fresh, or wet-weight basis; a few are on a lipid-weight basis.

Residue testing for endrin and 12-ketoendrin (Table 26) indicated that the 2 deer mice found dead had been poisoned by endrin, and that the hand-caught deer mouse and prairie dog were suffering from endrin intoxication. In the case of the prairie dog, endrin residues (brain $=0.71 \mathrm{ppm}$, liver $=3.32 \mathrm{ppm}$ ) sugges ted that it may have been near death. Apparently healthy resident wildlife collected on or adjacent to endrin-treated areas at various postspray intervals all had endrin and 12-ketoendrin residues at much lower levels than those found in dead or intoxicated animals. Whether only unaffected or mildly affected animals were trappable remains unknown; similarly, we do not know 


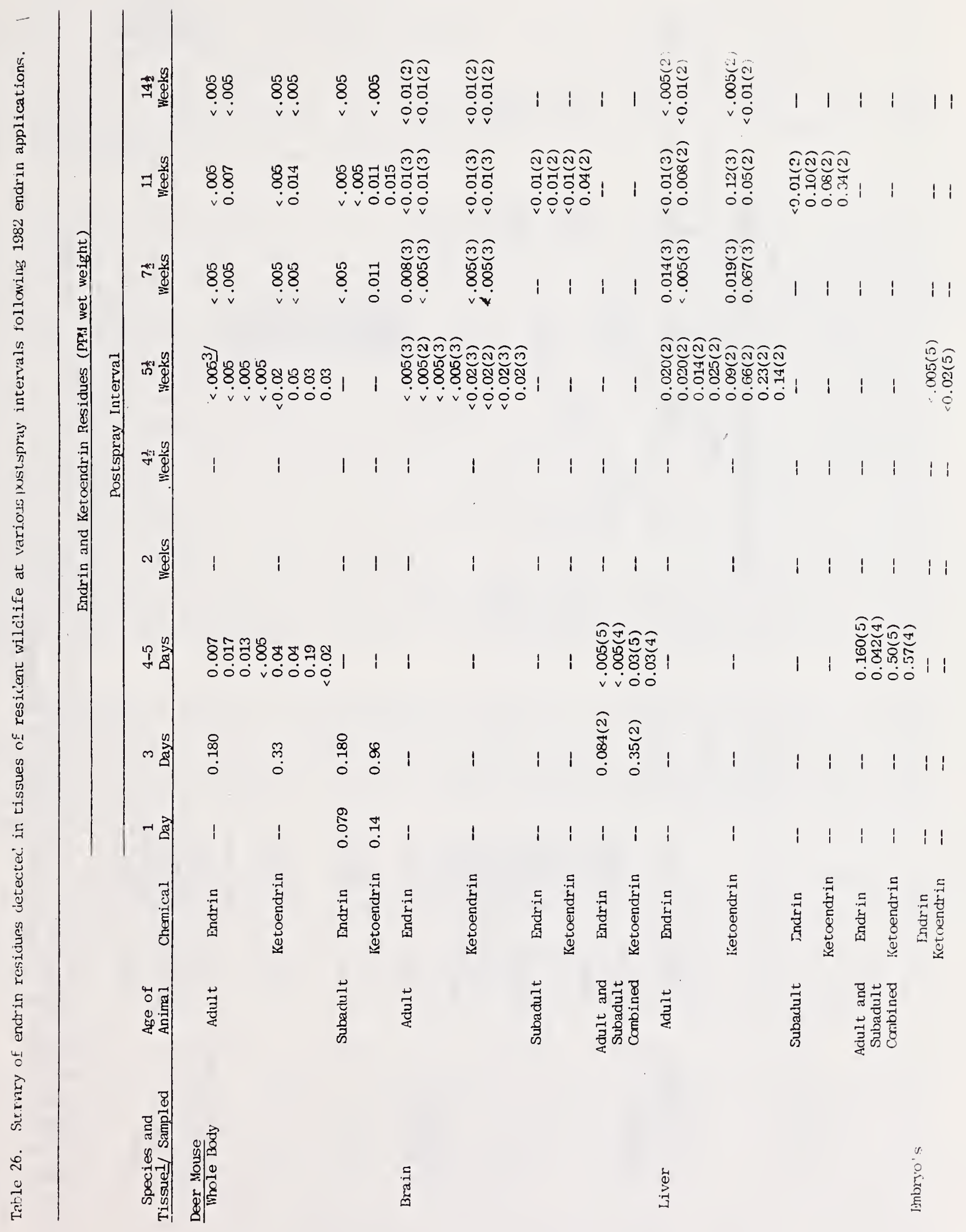




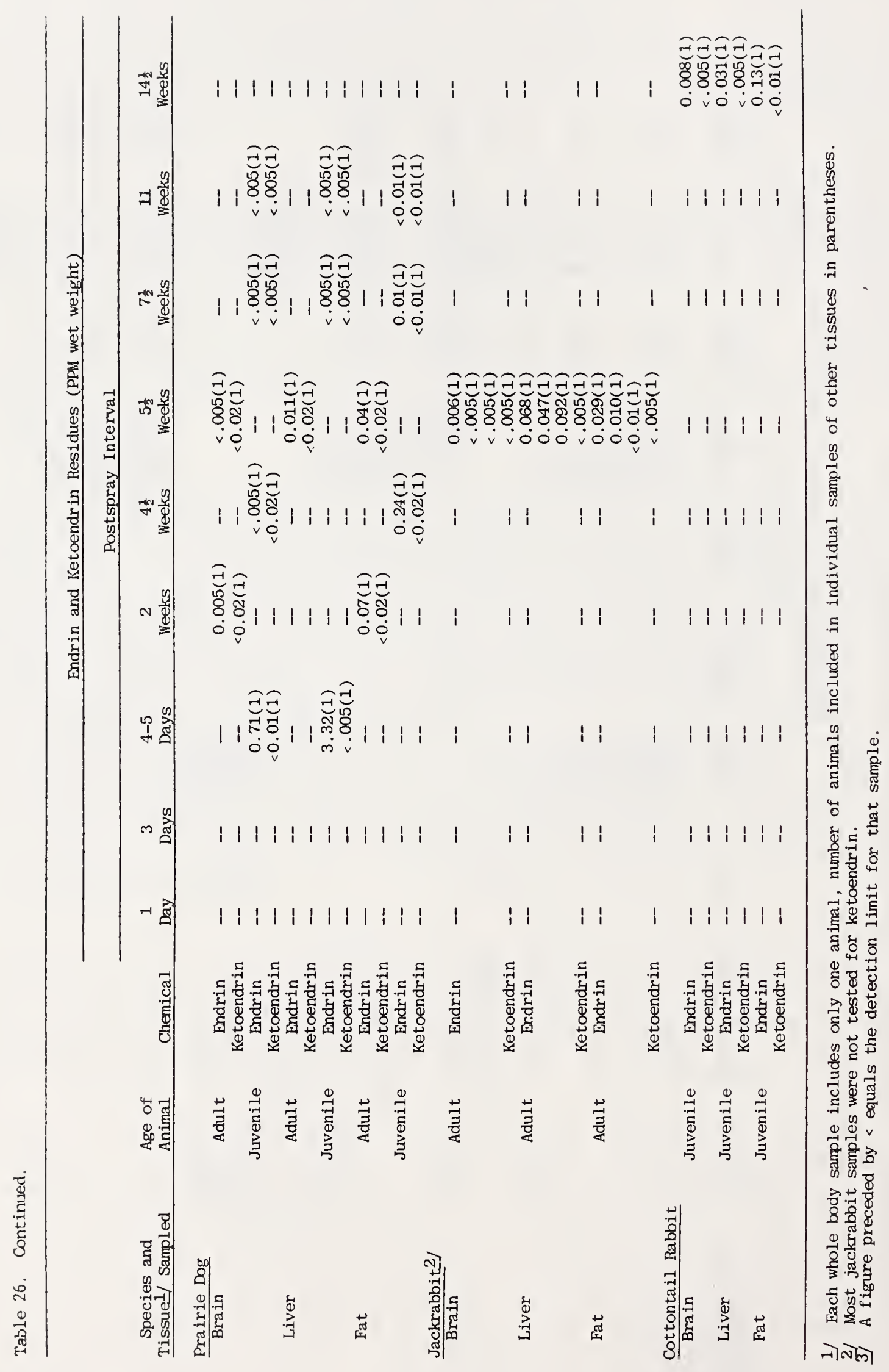


whether or not trapping adequately sampled all segments of the populations under study.

The absence of detectable 12-ketoendrin residues in prairie dogs and 2 species of rabbits suggested that those species do not produce that particular metabolite. This generally agreed with the findings of Bedford et al. (1975b) who detected only trace amounts of $12-k e t o e n d r i n$ in the domestic rabbit. These findings also suggested that those species do not need to be analyzed for that compound in future studies.

Laboratory studies of the effects of endrin on deer mice have shown that significant parental mortality occurred at levels of 2 ppm or more in the diet and that surviving parents receiving concentrations of $4 \mathrm{ppm}$ or more weaned significantly fewer young (Morris 1968). Similarly, endrin has resulted in significant parental mortality and smaller litters (Good and Ware 1969), as well as birth defects (Ottolenghi et al. 1973), among laboratory mice. Results of those studies suggested that population losses of deer mice (and probably other species as well), other than the direct poisoning noted, occurred during our studies. However, the lack of prespray population information precluded assessing the magnitude or consequences of such losses. McEwen et al. (1972) reported that 4 species of mammals succumbed to direct endrin poisoning during similar studies in Colorado, with jackrabbits being particularly sensitive. Larger mamals, including cattle, deer, and pronghorn, have also been victimized by endrin (Anonymous 1968, Colorado Department of Agriculture 1968, Hepworth and Roby 1968, Environmental Protection Agency $1980 \mathrm{~b})$.

Several ducks, 2 harriers, and a variety of small birds were collected on or near endrin-treated fields at various postspray intervals and tested for endrin and other residues. The dead horned lark found in a treated field 3 days postspray contained no chlorinated hydrocarbon residues; its cause of death remains unknown.

All postspray small birds were collected from, or within 250 yd of, treated fields, as were 1 of the harriers and all ducks taken $51 / 2$ weeks postspray or before. The second harrier was taken approximately $0.3 \mathrm{mi}$ from the nearest endrin-treated field, while the $141 / 2$ week postspray duck collections were made at distances of 0.4 to $1.75 \mathrm{mi}$ from the nearest treated fields.

Birds collected within or around endrin-treated fields showed an immediate uptake and accumulation of endrin in various tissues (Table 25). Elevated endrin concentrations remained for at least $51 / 2$ weeks in all birds sampled, and much longer for harriers. Based on residue levels in fat at $41 / 2$ and $51 / 2$ weeks postspray, endrin in ducks within treated areas probably remained at elevated levels (compared to prespray samples) for some time after this. Harriers contained higher endrin residues than any of their potential prey species sampled at the same time. 
Eggs removed from the oviducts of 2 female horned larks at 2 and $41 / 2$ weeks postspray contained 1.10 and $0.15 \mathrm{ppm}$ endrin, respectively. The higher level is well above estimated critical endrin residue levels which, if exceeded, caused reproductive impairment in screech owls $(\simeq 0.3 \mathrm{ppm}$, Fleming et al. 1982) and brown pelicans ( $\simeq 0.5 \mathrm{ppm}$, Blus 1982). Those levels suggested that small birds, which were breeding on endrin-treated areas, may have experienced reduced production even if no direct endrin poisoning occurred. However, direct poisoning probably did occur, as indicated by 2 whole body samples of horned larks that had endrin concentrations (wet weight) greater than those in birds found dead in similar studies in Colorado (McEwen et al. $1972)$.

Endrin residues in the 2 horned lark egg samples were approximately $31 \%$ and $63 \%$ of the endrin levels found in the fat of the birds from which the eggs were taken. Assuming that endrin residues in waterfowl eggs also approximated 30-65\% of residue levels in female parent fat, and that residue levels in eggs which result in impaired reproduction were on the order of 0.5 ppm, endrin levels that approached or exceeded the critical level would have occurred in eggs of waterfowl residing in endrintreated areas for several weeks following spraying. Under these circumstances, production would suffer even if no direct endrin poisoning occurred.

Several miscellaneous samples were obtained at various postspray intervals, including: 2 cutworm samples taken 5 days postspray; 1 sediment sample at $51 / 2$ weeks and 5 samples at 7 $1 / 2$ weeks postspray; and 2 barley samples (seeds removed from heads of standing grain missed during harvest) taken $141 / 2$ weeks postspray. All sediment samples, both barley samples, and 1 of the cutworm samples contained $<0.005 \mathrm{ppm}$ endrin. The second cutworm sample had $1.06 \mathrm{ppm}$ endrin which is within the range $(0.4-5.7 \mathrm{ppm})$ of residues found in insects up to 10 days postspray by McEwen et al. (1972). Other dead or dying insects frequently noted at the time the cutworms were collected included grasshoppers and crickets. Because a high percentage of the horned larks and McCown's longspurs collected up to 16 days postspray in chlorpyrifos treated fields (Appendix I) contained cutworm larvae in their stomachs, the mode of endrin contamination for small birds seems obvious. Since food containing over 1 ppm endrin existed for at least 5 days following spraying, direct poisoning of those species was likely, especially if nestlings were being fed contaminated insects.

\section{Chlorpyrifos Studies}

The time between study site selection and spray application was too short to allow conducting prespray wildlife population surveys on one of the chlorpyrifos-treated areas. Prespray small mammal surveys were completed on the second chlorpyrifos plot but unfavorable weather precluded obtaining prespray bird data. 
A few nests of small birds were found on, or adjacent to, chlorpyrifos-treated areas prior to spraying. Periodic checking of those nests for up to 16 days postspray indicated no abnormal. mortality compared to nests located on nearby, untreated control areas.

No dead or visibly intoxicated birds were noted during the course of collecting small birds for brain ChE analysis. No systematic carcass searches or specific toxicity or behavioral observations were made.

Brain cholinesterase tests on horned larks $(\mathbb{N}=54)$, collected at various postspray intervals, indicated that cholinesterase activity in 2 individuals approached lethal levels. This included 1 bird at 51\% inhibition 3 days postspray and another at $42 \% 9$ days postspray. Criteria of Ludke et al. (1975) indicated that $250 \%$ depression in dead birds suggests death caused by an anti-ChE agent. Limited postspray sampling of McCown's longspurs indicated no birds with brain cholinesterase activity reduced more than 19\% (Appendix J).

Ninety-five percent or more of the horned larks and McCown's longspurs collected 3 days postspray contained cutworm larvae in their stomachs. This figure declined to $71 \%$ at $9-16$ days postspray, compared to $27 \%$ or less for control specimens, some of which were taken $>1 \mathrm{mi}$ from treated fields (Appendix I). The decrease in both cutworms and total insects at increasing postspray intervals was not unexpected because availability of insects on treatment areas would increase immediately after spraying, with a gradual decline and approach to levels found in controls.

Birds appear capable of detecting the presence of pesticides on food items (Bennett and Prince 1981, Hill 1972, Ridsdale and Granett 1969), and respond by selecting untreated foods (if available) or reducing food intake. Pheasants given only lorsban-treated food reduced their intake by more than $90 \%$, and stopped feeding after the 1 st or 2 nd day of testing (Bennett and Prince 1981). Reduced egg production among pheasants has been found to result from reduced food consumption (Stromborg 1977).

Because our chlorpyrifos-treated areas were small (maximum of 40 acres), they did not encompass total home ranges of individual birds, enabling them to spend varying amounts of time in untreated areas. Large scale (i.e. block) spraying of chlorpyrifos would encompass the entire home range of a large number of individuals of many bird species. Some direct bird mortality would be expected following such extensive applications, and sublethal concentrations could cause indirect affects by effectively reducing available foods. Despite these drawbacks and its moderate oral toxicity to birds (Table 23), chlorpyrifos applied at 6-8 oz/A was registered as an alternative to endrin for cutworm control in cereal grains in Canada in 1977 (McDonald 1981). 
Results of small mammal trapping on chlorpyrifos treatment and control plots showed no changes attributable to treatment. Postspray population estimates increased on both areas over prespray estimates (20\% on the treatment and $18 \%$ on the control). No significant differences occurred between pre-and postspray populations on either area. Postspray recaptures of animals marked prior to spraying included $64 \%$ of those present on the treatment plot and $71 \%$ of those on the control.

\section{Permethrin Studies}

Pre- and postspray surveys of breeding bird and small mammal populations on the control and 2 treatment plots gave variable results, partly because the prespray estimates on the stubble treatment were significantly different than those on the other 2 plots. Therefore, comparisons between plots would be invalid for both birds and mammals.

Estimates of bird populations on all 3 plots declined between pre- and postspray sampling periods. Declines amounted to $24 \%$ and $48 \%$ on treatment plots and $31 \%$ on the control. These declines were not unexpected since 3 weeks elapsed between the start of those surveys and their completion. Vegetation growth on all plots over this time decreased bird visibility. Concurrently, many female birds began incubating during the latter part of the period, and breeding activities of males were declining in intensity. Analysis of breeding bird population data showed no significant differences between pre- and postspray bird population levels on any of the plots.

Changes in small mammal populations varied, with 1 treatment and the control plot showing declines, while the second treatment plot showed an increase in population between pre-and postspray trapping periods. However, none of the postspray population estimates differed significantly from prespray estimates on the same area. Fifty-four percent of the marked animals present on the control area at the end of the prespray trapping period were subsequently recaptured during postspray trapping. Similar figures for the 2 treatment plots were $59 \%$ and $60 \%$.

\section{Comparative Efficacies of Tested Insecticides}

Permethrin has been tested against a number of noctuid lepidopterans in greenhouse and/or experimental test plots. These have included several different crops plus endrin and/or chlorpyrifos and other chemicals for comparative studies (Harris et al. 1978, Broadley and Rossiter 1979, Cheng 1980).

Oral toxicity tests with cutworms showed that permethrin was more toxic than endrin, whereas chlorpyrifos was 2-4 times less toxic (McDonald 1979). In mbsequent greenhouse tests on barley, permethrin at $2-4$ oz/A gave control comparable to endrin at 4 oz/A, while chlorpyrifos required 8 oz/A to produce similar 
results. Permethrin was more effective and chlorpyrifos was less effective than endrin when applied to bare soil at comparable rates. Microplot tests on barley confirmed the effectiveness of permethrin for army cutworm control at $2 \mathrm{oz} / \mathrm{A}$.

McDonald (1981) found that oral toxicity of permethrin to pale western cutworms equalled that of endrin, and that both were 3-4 times more toxic than chlorpyrifos. Permethrin was 14-17 times more toxic than endrin and chlorpyrifos as a contact poison. In comparing oral versus contact toxicities for these chemicals, permethrin was over twice as effective as a contact poison; endrin was 8 times, and chlorpyrifos was over 2 times, less toxic by contact than as oral poisons.

Permethrin sprayed on wheat plants or bare soil in greenhouse trials at $10 z / A$ was as effective on pale western cutworms as endrin at 4 oz and chlorpyrifos at 8 oz/A. Permethrin applied to bare soil at 4 oz/A gave significantly better control than either endrin at 4 oz or chlorpyrifos at 8 oz/A (McDonald 1981).

In small plot field tests on existing populations of pale western cutworms in winter wheat, DePew (1980) reported that permethrin at 1.6 oz/A gave the best results at 7 days posttreatment, and was significantly better than other treatments tested. Permethrin at $0.8 \mathrm{oz} / \mathrm{A}$ ranked second in effectiveness, but did not differ significantly from endrin ( $3.2 \mathrm{oz} / \mathrm{A})$. Permethrin plots had the fewest cutworms 14 days posttreatment with no significant differences between the 2 rates. Endrin $(3.2$ oz/A) did not differ significantly from permethrin at $0.8 \mathrm{oz} / \mathrm{A}$, but gave less control.

Preliminary results from 1982 Montana field tests (supplied by the MDA) showed promising results were obtained with permethrin. Where endrin, chlopyrifos, and permethrin were applied to separate plots on the same area, endrin ( 4 oz/A) ano chlorpyrifos (16 oz/A) each reduced cutworm populations by $75 \%$, whereas permethrin $(1.6 \mathrm{oz} / \mathrm{A})$ resulted in an $85 \%$ reduction.

Two major concerns of grain producers and others in 19811982, against widespread acceptance of permethrin and/or chlorpyrifos over endrin, were the unknown efficacy against cutworms under normal cropping conditions and higher chemical costs/A. The above data all suggested that permethrin may be superior to either endrin or chlorpyrifos for cutworm control in Montana cereal grains. The cost factor in spring 1983 also favored use of permethrin ( $\$ 5.00 / \mathrm{A})$ over endrin $(\$ 6.00 / \mathrm{A})$ and chlorpyrifos ( $\$ 8.35 / \mathrm{A}$ at 16 oz/A rate) (0.G. Bain pers.comm.).

One disadvantage may remain before replacement of endrin with permethrin for cutworm control in cereal grains in Montana. That is that, although it is far less hazardous to terrestrial wildlife than either endrin or chlorpyrifos, permethrin is relatively toxic to fish and other aquatic organisms; it is still 3 to 4 times less toxic to these organisms than endrin. 
Limited data suggest that permethrin residues on crops disappear within a few weeks (Harris et al. 1978). Permethrin's persistence on vegetation, and in wildlife, should be ascertained so that replacement of endrin by this or another suitable alternative can be accomplished as soon as possible. Unfortunately, EPA sponsored studies of the affects of endrin and potential alternatives on wildlife initiated in March 1983 in Montana did not include permethrin. Knowledge of permethrin's persistence in wildife tissues would be extremely valuable because of reports that it may be carcinogenic (Marshall 1982). No decision regarding carcinogenicity has been made as of this date.

\section{Other Chlorinated Hydrocarbon Compounds}

Laboratory results reporting residues of other chlorinated hydrocarbon compounds in Montana wildlife generated additional concern for the welfare of that wildlife, and humans that might consume them. Documented deleterious effects of some of those compounds are well known, while those of others are not. Also, the synergistic, or combined effects of 2 or more of those compounds with one another, or with other environmental pollutants are largely unknown. Residues of those compounds, and their documented and potential hazards, are discussed in detail for heptachlor and polychlorinated biphenyls, and to a lesser extent for the remaining compounds. No fish or aquatic invertebrates were tested for any of these compounds.

\section{Heptachlor and Heptachlor Epoxide}

Heptachlor is used extensively in Montana as a preplanting seed treatment to protect seed grain and emerging plants from damage by wireworms. Pesticide dealer records provided by the MDA showed that more than 177,000 acres could have been treated with heptachlor in 1981 (Fig. 16).

Heptachlor changes rapidly to its epoxide in soils (Gannon and Bigger 1958), on plants (Gannon and Decker 1958), and in most other living organisms (Brooks 1974a). Heptachlor epoxide (HE) is stable (Brooks 1974b), and is more persistent (Gannon and Bigger 1958) and considerably more toxic than the parent material (Rudd and Genelly 1956, Radeleff 1964). Heptachlor epoxide is the compound normally found in animal tissues, although occasionally both may be found.

Heptachlor typically contains chlordane-related compounds such as alpha- (cis) chlordane, gamma- (trans) chlordane and nonachlor as byproducts of its manufacture or contaminants (Brooks 1974a, Blus et al. 1979, Stickel et al. 1979b). Both alpha- and gamma-chlordane are oxidized in animals to form oxychlordane, which is stored in fat (Brooks 1974a). Any of these chlordane compounds may occur as a result of heptachlor use and not necessarily from exposure to chlordane. On the other hand, chlordane is a mixture of chlorinated hydrocarbons consisting 


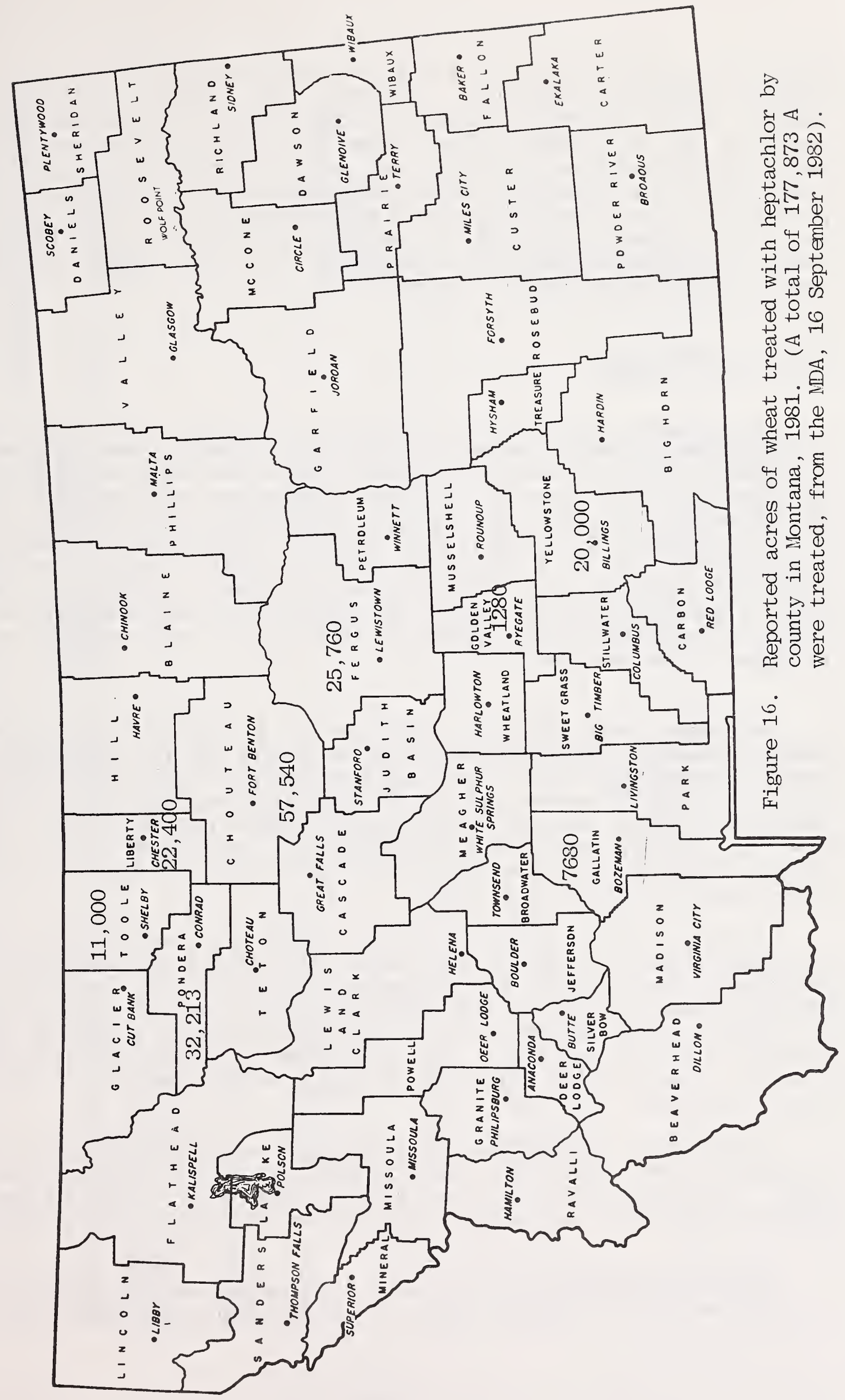


primarily of alpha- and gamma-chlordane isomers, plus other closely related compounds, including heptachlor. Although heptachlor and $\mathrm{HE}$ found in Montana wildlife could have resulted from exposure to chlordane rather than heptachlor, chlordane has not been registered for agricultural use in Montana in recent years. Therefore, residues of heptachlor and HE in Montana wildife probably came from local heptachlor exposure, or exposure to heptachlor and/or chlordane outside Montana. Oxychlordane and other chlordane-related compounds in our samples will be discussed in more detail later.

\section{Resident Wildiife}

Big Game. Residue test results indicated that only 2 of the 12 big game animals tested ( 11 fat and 1 brain sample) contained detectable levels of $\mathrm{HE}$; none were above the USDA action level of $0.3 \mathrm{ppm}$ in fat of domestic meats. Big game samples positive for $\mathrm{HE}$ included fat of a pronghorn collected in October 1981 in Rosebud County $(0.01 \mathrm{ppm})$, and fat of a white-tailed deer taken in November 1981 in Fallon County $(0.17 \mathrm{ppm})$. Numbers of samples tested for heptachlor and HE were too small to draw any conclusions regarding either uptake, accumulation, and impacts on those species, or potential hazards to humans from eating various tissues of those species.

Upland Game Birds. Fifteen of 56 upland game bird fat samples tested contained detectable levels of $\mathrm{HE}$, including those from 8 pheasants and 7 sharp-tailed grouse (Table 27). Pheasants positive for HE were collected in Cascade, Dawson and Fallon Counties, while positive sharptails came from Chouteau, Custer, Dawson, Fallon, and Richland Counties. Pesticide dealer records indicated heptachlor sales in only one of those counties (Chouteau) in 1981 (Fig. 16).

Three of 15 upland bird fat samples positive for HE (2 sharptails and 1 pheasant) exceeded the USDA's action level. The sharptails were collected in mid-September 1981 in Dawson and Fallon Counties, while the pheasant was taken in Cascade County in October 1982, adjacent to a field that had been seeded approximately 4 weeks earlier. In each instance the bird was taken within 3 days of the opening of the hunting season for the species involved.

Additional upland bird tissues tested for heptachlor and HE included 2 meat samples, and one each of liver, brain, food, and egg. The only detectable HE residue in those samples was 0.02 $\mathrm{ppm}$ in a pheasant egg collected in Dawson County in May 1982.

Small Mammals. Test results suggested rather widespread HE contamination of small mammals (67\% of species and $14 \%$ of all 


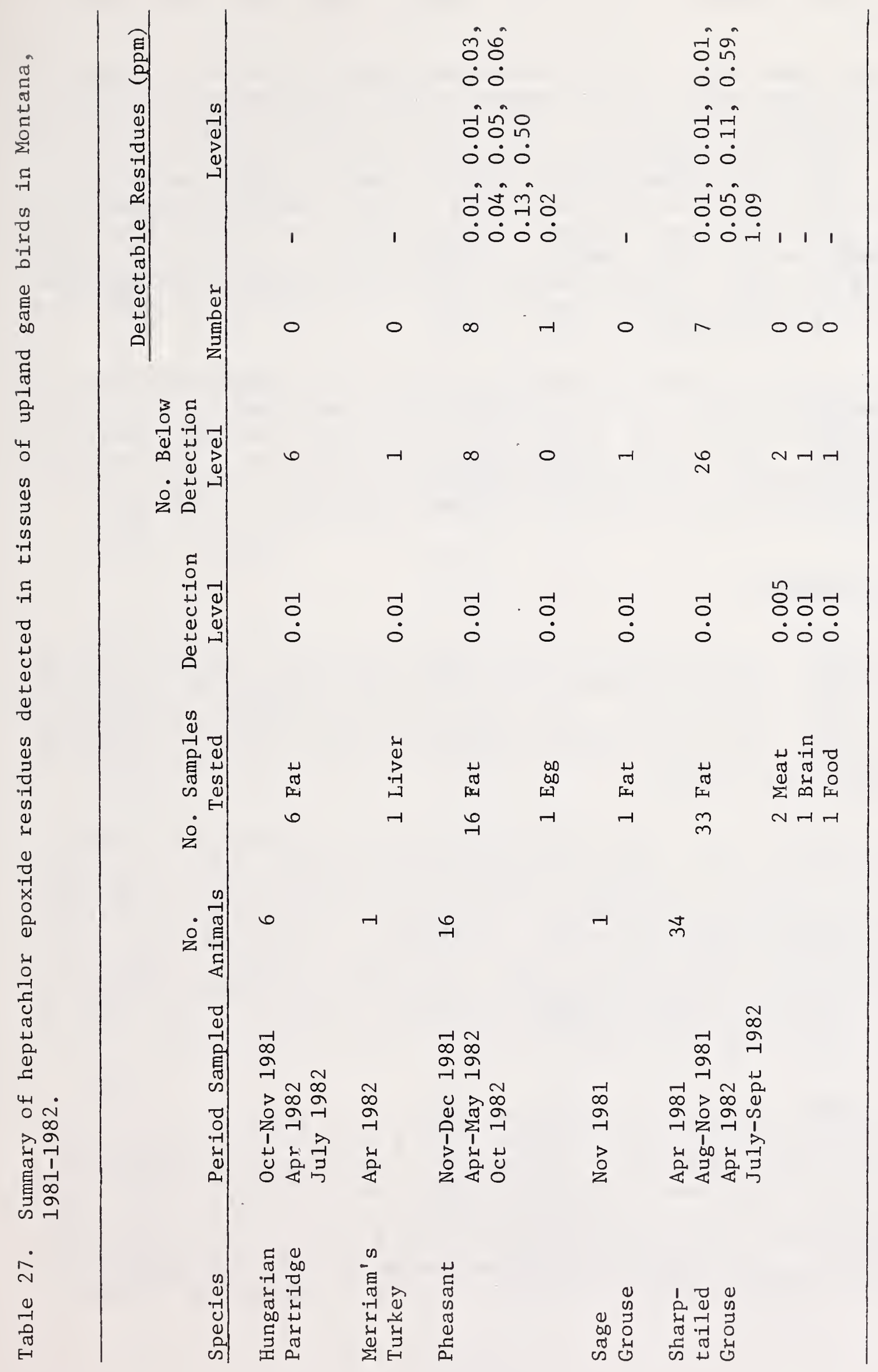


samples tested), despite the small sample size for most species (Table 28).

Although deer mice constituted over $56 \%$ of the total samples tested, the percentage of deer mouse samples positive for HE was almost identical to that of all the other samples combined ( $13.8 \%$ vs 13.5\%). This suggested that the deer mouse is probably representative of $\mathrm{HE}$ contamination in small mammals in general. Because deer mice constituted a majority of the samples, it was not surprising that maximum residue levels found in individual deer mouse tissues were higher than in corresponding tissues of other species ( $T a b l e$ 28). The results also indicated a continual supply of HE was available in the small mammal portion of the food supply of predators.

Because small mammal sampling for $\mathrm{HE}$ was restricted to the 1982 endrin test site, or to 5 locations where endrin had been found in other species in 1981, positive small mammal samples were obtained from only 6 locations in 4 counties. However, HE was found in samples from every location tested, further indicating widespread $\mathrm{HE}$ contamination of small mammals in Montana.

\section{Migratory Wildilife}

Waterfow 1. Nearly 55\% of all the waterfowl samples tested contained $H E$, and included all species tested except the whistling swan (Table 29). The lack of HE residues in 4 swans sampled was not unexpected since they were fall migrants stopping in Montana after leaving their breeding grounds on the tundra to the north (Bellrose 1976).

Over 56\% ( 107 of 189) of the waterfowl fat samples tested were positive for HE. Thirteen samples (nearly $7 \%$ of all fat samples) collected in spring and summer 1982 exceeded the USDA action level. Those included 4 baldpates from Chouteau, Musselshell, and Powder River Counties; 1 gadwall, 1 green-winged teal, and 1 mallard from Chouteau County; 3 pintails from Chouteau and Custer Counties; 2 ruddy ducks fron Park County; and 1 shoveler from Custer county. The maximum HE residue level was $47.1 \mathrm{ppm}$ in a male mallard from chouteau County; it was also positive for heptachlor.

Additional waterfowl tissues which were positive for HE included 7 of 13 meat, 2 of 9 food, 4 of 9 brain, 3 of 3 egg, and 0 of 1 cooked meat samples. Maximum HE residues included: meat, $1.33 \mathrm{ppm}$; food, $0.06 \mathrm{ppm}$ (also contained heptachlor); brain, 0.75 ppm; and egg, $6.98 \mathrm{ppm}$. Maximum HE levels in meat, food, and brain samples were from the Chouteau County mallard that had 47.1 ppm in its fat. The highest residue found in eggs was from a 2egg composite sample from the same vicinity in Chouteau county. 


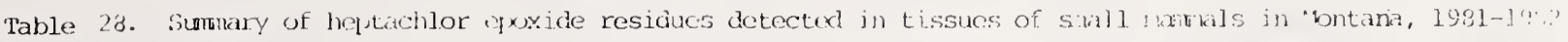

\begin{tabular}{|c|c|c|c|c|c|c|c|}
\hline \multirow[b]{2}{*}{ Species } & \multirow[b]{2}{*}{$\begin{array}{l}\text { Period } \\
\text { Simplad }\end{array}$} & \multirow[b]{2}{*}{$\begin{array}{c}\text { No. } \\
\text { Animals }\end{array}$} & \multirow{2}{*}{$\begin{array}{l}\text { No. Samples } \\
\text { Tested }\end{array}$} & \multirow[b]{2}{*}{$\begin{array}{l}\text { Detection } \\
\text { Ievel }\end{array}$} & \multirow[b]{2}{*}{$\begin{array}{l}\text { Wo. Below } \\
\text { Detection } \\
\text { Level }\end{array}$} & \multicolumn{2}{|c|}{ Detectiable Residues (pum) } \\
\hline & & & & & & Nusnter & Ievels \\
\hline $\begin{array}{l}\text { Black-tailed } \\
\text { Prairie Dog }\end{array}$ & June-Aurg 1982 & 6 & $\begin{array}{l}6 \text { Brain } \\
4 \text { Liver } \\
5 \text { Fat }\end{array}$ & $\begin{array}{l}0.01 \\
0.005 \\
0.01\end{array}$ & $\begin{array}{l}6 \\
2 \\
3\end{array}$ & $\begin{array}{l}0 \\
2 \\
2\end{array}$ & $\begin{array}{l}- \\
0.008,0.006 \\
0.28,0.02\end{array}$ \\
\hline $\begin{array}{l}\text { Cottontail } \\
\text { Rabbit }\end{array}$ & $\begin{array}{l}\text { Jan } 1982 \\
\text { Sept } 1982\end{array}$ & 2 & $\begin{array}{ll}2 & \text { Fat } \\
1 & \text { Brain } \\
1 & \text { Liver }\end{array}$ & $\begin{array}{l}0.01 \\
0.005 \\
0.005\end{array}$ & $\begin{array}{l}2 \\
1 \\
1\end{array}$ & $\begin{array}{l}0 \\
0 \\
0\end{array}$ & $\begin{array}{l}- \\
-\end{array}$ \\
\hline Deer Mouse & $\begin{array}{l}\text { Nov } 1981 \\
\text { Apr-Sept } 1982\end{array}$ & $\begin{array}{r}16 \\
5\end{array}$ & $\begin{array}{l}43 \text { Brain } \\
42 \text { Liver } \\
3 \text { Embryos } \\
1 \text { Newborn }\end{array}$ & $\begin{array}{l}0.01 \\
0.01 \\
0.005 \\
0.005\end{array}$ & $\begin{array}{r}63 \text { li } \\
37 \\
39 \\
2 \\
1\end{array}$ & $\begin{array}{l}6 \\
3 \\
1 \\
0\end{array}$ & $\begin{array}{l}0.005,0.010,0.022,0.032, \\
0.088,0.190,0.200,3.49, \\
4.30,4.63 \\
0.02,0.03,0.08,0.11, \\
0.89,1.99 \\
0.022,0.04,30.40 \\
1.31 \\
-\end{array}$ \\
\hline $\begin{array}{l}\text { larvest } \\
\text { Mouse }\end{array}$ & $\begin{array}{l}\text { IJov } 1981 \\
\text { May } 1982\end{array}$ & 7 & $\begin{array}{l}6 \text { Whole Body } \\
2 \text { Brain } \\
2 \text { Liver }\end{array}$ & $\begin{array}{l}0.005 \\
0.01 \\
0.01\end{array}$ & $\begin{array}{l}6 \\
2 \\
2\end{array}$ & $\begin{array}{l}0 \\
0 \\
0\end{array}$ & $\begin{array}{l}- \\
-\end{array}$ \\
\hline House Mouse & Nov 1981 & 3 & $\begin{array}{l}3 \text { Whole Body } \\
1 \text { Brain } \\
1 \text { Liver }\end{array}$ & $\begin{array}{l}0.005 \\
0.01 \\
0.01\end{array}$ & $\begin{array}{l}3 \\
1 \\
1\end{array}$ & $\begin{array}{l}0 \\
0 \\
0\end{array}$ & $\begin{array}{l}- \\
-\end{array}$ \\
\hline Meaciow Vole & $\begin{array}{l}\text { Nov } 1981 \\
\text { Apr-May } 1982\end{array}$ & 16 & $\begin{array}{l}11 \text { whole Body } \\
5 \text { Brain } \\
5 \text { Liver }\end{array}$ & $\begin{array}{l}0.005 \\
0.01 \\
0.01\end{array}$ & $\begin{array}{r}10 \\
5 \\
5\end{array}$ & $\begin{array}{l}1 \\
0 \\
0\end{array}$ & $\begin{array}{l}0.054 \\
- \\
-\end{array}$ \\
\hline Pocket Mouse & Nov 1981 & 1 & 1 Whole Body & 0.005 & 0 & 1 & 0.033 \\
\hline Porcupine & May 1982 & 1 & 1 Fat & 0.01 & 0 & 1 & 0.01 \\
\hline Prairie Vole & Nov 1981 & 3 & $\begin{array}{l}3 \text { Whole Body } \\
1 \text { Brain } \\
1 \text { Liver }\end{array}$ & $\begin{array}{l}0.005 \\
0.01 \\
0.01\end{array}$ & $\begin{array}{l}1 \\
1 \\
1\end{array}$ & $\begin{array}{l}2 \\
0 \\
0\end{array}$ & $\begin{array}{l}0.039,0.040 \\
- \\
-\end{array}$ \\
\hline $\begin{array}{l}\text { Richardson's } \\
\text { Ground } \\
\text { Squirrel }\end{array}$ & Apr 1982 & 3 & $\begin{array}{l}3 \text { Brain } \\
3 \text { Liver } \\
3 \text { Fat } \\
1 \text { Food }\end{array}$ & $\begin{array}{l}0.01 \\
0.005 \\
0.01 \\
0.005\end{array}$ & $\begin{array}{l}3 \\
3 \\
3 \\
1\end{array}$ & $\begin{array}{l}0 \\
0 \\
0 \\
0\end{array}$ & $\begin{array}{l}- \\
- \\
- \\
-\end{array}$ \\
\hline $\begin{array}{l}\text { Thirteern-lined } \\
\text { (iround } \\
\text { Spuirrel }\end{array}$ & May 1982 & 2 & $\begin{array}{l}2 \text { Brain } \\
2 \text { Liver } \\
2 \text { Fat } \\
1 \text { Food }\end{array}$ & $\begin{array}{l}0.01 \\
0.01 \\
0.01 \\
0.005\end{array}$ & $\begin{array}{l}2 \\
1 \\
2 \\
1\end{array}$ & $\begin{array}{l}0 \\
1 \\
0 \\
0\end{array}$ & $\begin{array}{l}- \\
- \\
-\end{array}$ \\
\hline $\begin{array}{l}\text { White-tailod } \\
\text { Jackrabbit }\end{array}$ & $\begin{array}{l}\text { Apr-May } 1982 \\
\text { July } 1982\end{array}$ & 5 & $\begin{array}{l}5 \text { Fat } \\
3 \text { Brain } \\
3 \text { Liver }\end{array}$ & $\begin{array}{l}0.01 \\
0.005 \\
0.005\end{array}$ & $\begin{array}{l}2 \\
3 \\
1\end{array}$ & $\begin{array}{l}3 \\
0 \\
2\end{array}$ & $\begin{array}{l}0.02,0.02,0.06 \\
- \\
0.012,0.006\end{array}$ \\
\hline
\end{tabular}




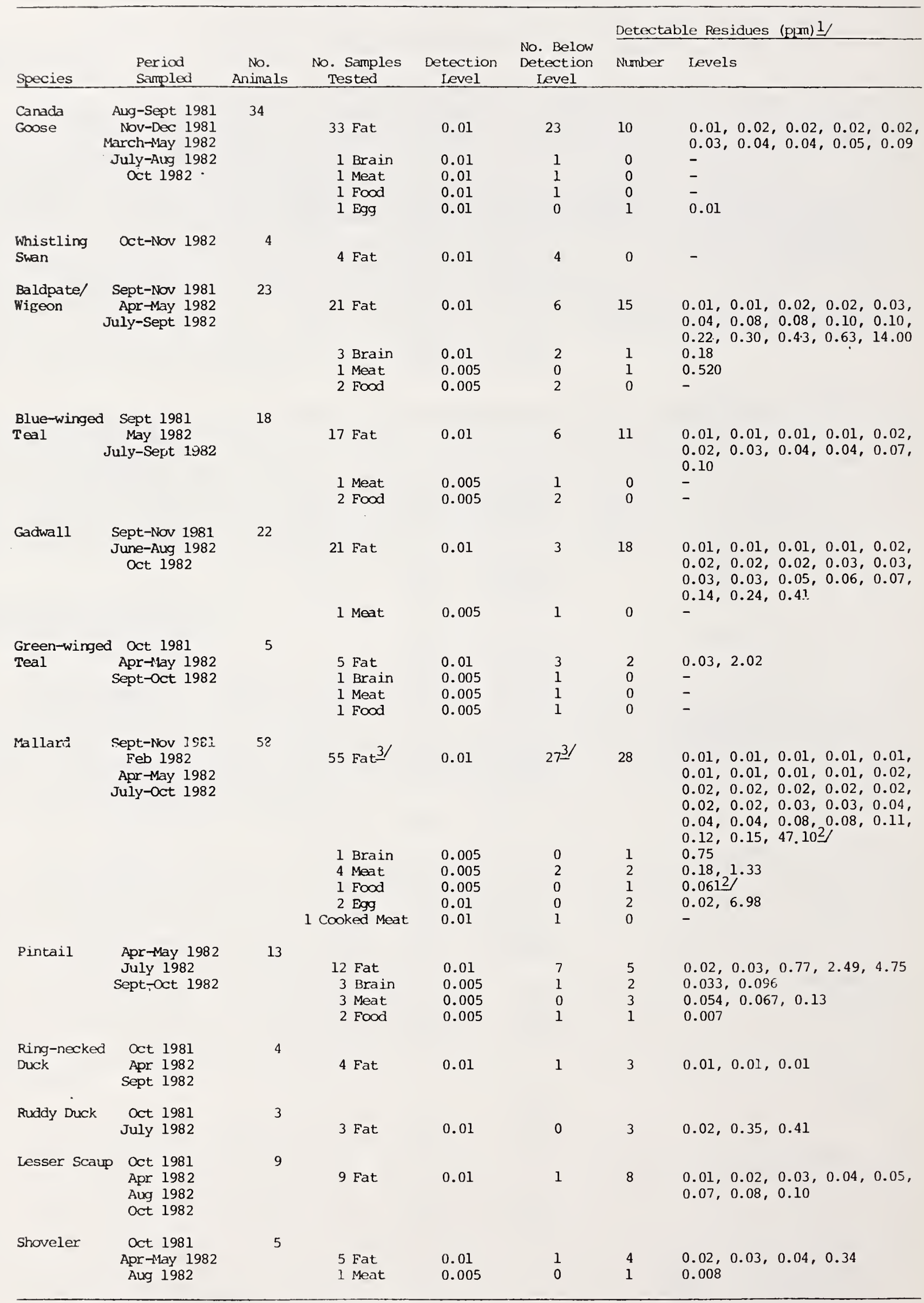

1) Primarily wet weight basis, but includes a few expressed on a lipid weight basis.

2) Also contained unchanged heptachlor.

3) 55 fat samples tested for most chemicals. Ixceptions are: DDT and DDD = 54 samples; endrin, dieldrin and DDE $=56$ samples. 
Other Aquatic Birds and Migratory Game Birds. Over 90\% of the fat samples from other species associated with aquatic habitats contained detectable levels of HE, although at low levels (Table 30). Every site from which these species were collected ( 5 sites in 5 counties) had birds with HE residues. Although the number of both sites sampled and samples tested were small, the results, when considered along with those for waterfowl, indicated widespread HE contamination of wetland habitats in Montana.

Two of 5 mourning dove fat samples tested were positive for HE (Table 30). One had only minor amounts of HE present, while the other, a bird taken in Fallon County in May 1982, had 53.0 ppm in its fat. The whole body (or carcass), brain, and food (crop contents) of this bird contained $2.60,1.62$ and 0.08 ppm HE, respectively. No unchanged heptachlor was detected in any dove sample.

Raptors. Fifteen of 16 raptor fat samples tested contained HE, including 8 at levels in excess of $0.5 \mathrm{ppm}$ and one that also contained $0.25 \mathrm{ppm}$ unchanged heptachlor (Table 31). Other raptor tissue samples positive for $\mathrm{HE}$ included 1 brain $(0.21 \mathrm{ppm})$ and 2 egg samples (0.08 and $0.64 \mathrm{ppm}) ; 1$ food sample lacked detectable HE residues. Raptor samples that tested positive for HE represented 6 species collected at 10 sites in 6 different counties. Although limited, those results also indicated widespread $\mathrm{HE}$ contamination in Montana.

Passerines. Over one-third of all the passerine bird samples tested following endrin spraying in 1981 contained HE residues (Table 32). The red-winged blackbird (collected in Dawson County in May 1982) was the only species not having detectable HE residues in at least one of its tissues. Maximum HE residues in passerine bird species included: whole body, 1.26; brain, 0.52; fat, 25.00; egg, 0.41; and food, none detected.

Like the small mammals, most of the passerine birds were collected from the 1982 endrin study site, or a few locations where positive endrin samples had been obtained in 1981. Therefore, testing for HE residues included samples from only 7 sites in 5 counties. HE was detected in samples from each of those sites.

A number of small bird species that form part of the normal prey of peregrine falcons were sampled at 5 potential peregrine reintroduction sites in Montana in June and July 1980. Whole body samples of individual birds, or pools of 5-12 birds each, were tested for organochlorine pesticides and PCB's by the FWS. Samples included 201 birds of 8 species, from all 5 sites, which were tested in 20 pools. An additional 30 birds representing 3 species and 3 sites ( 1 species/site) were tested individually. Data from these tests (DeWeese, FWS, unpublished data) are briefly summarized here. 
rable 30. Sumary of heptachlor epoxide residues detected in tissues of other acjuatic birds and mugratory yam birds in Montana, 1981-1982.

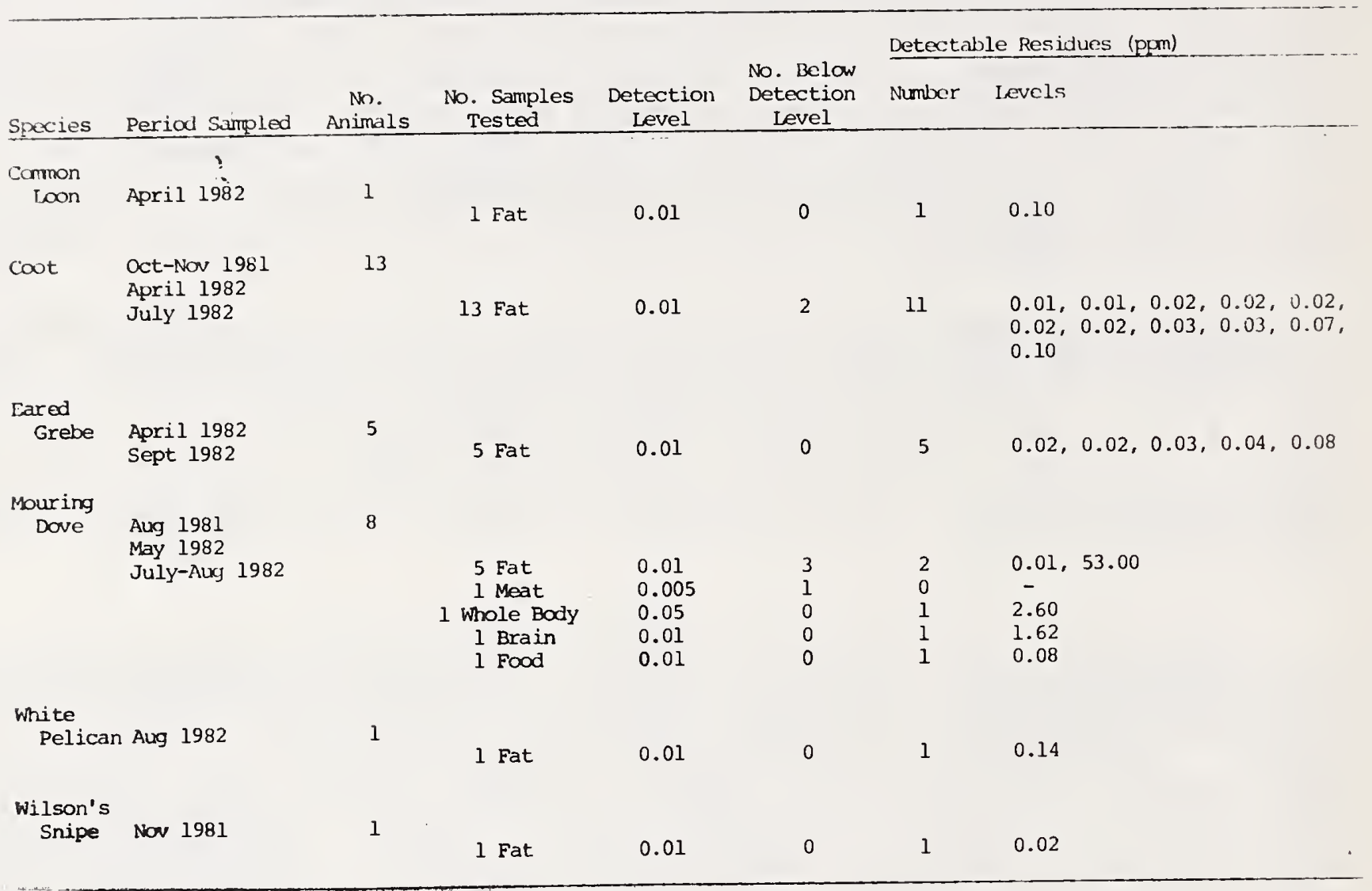

Table 31. Surmary of heptachlor epoxide residues detected in tissues of raptors in 1 bntana, $1981-1982$.

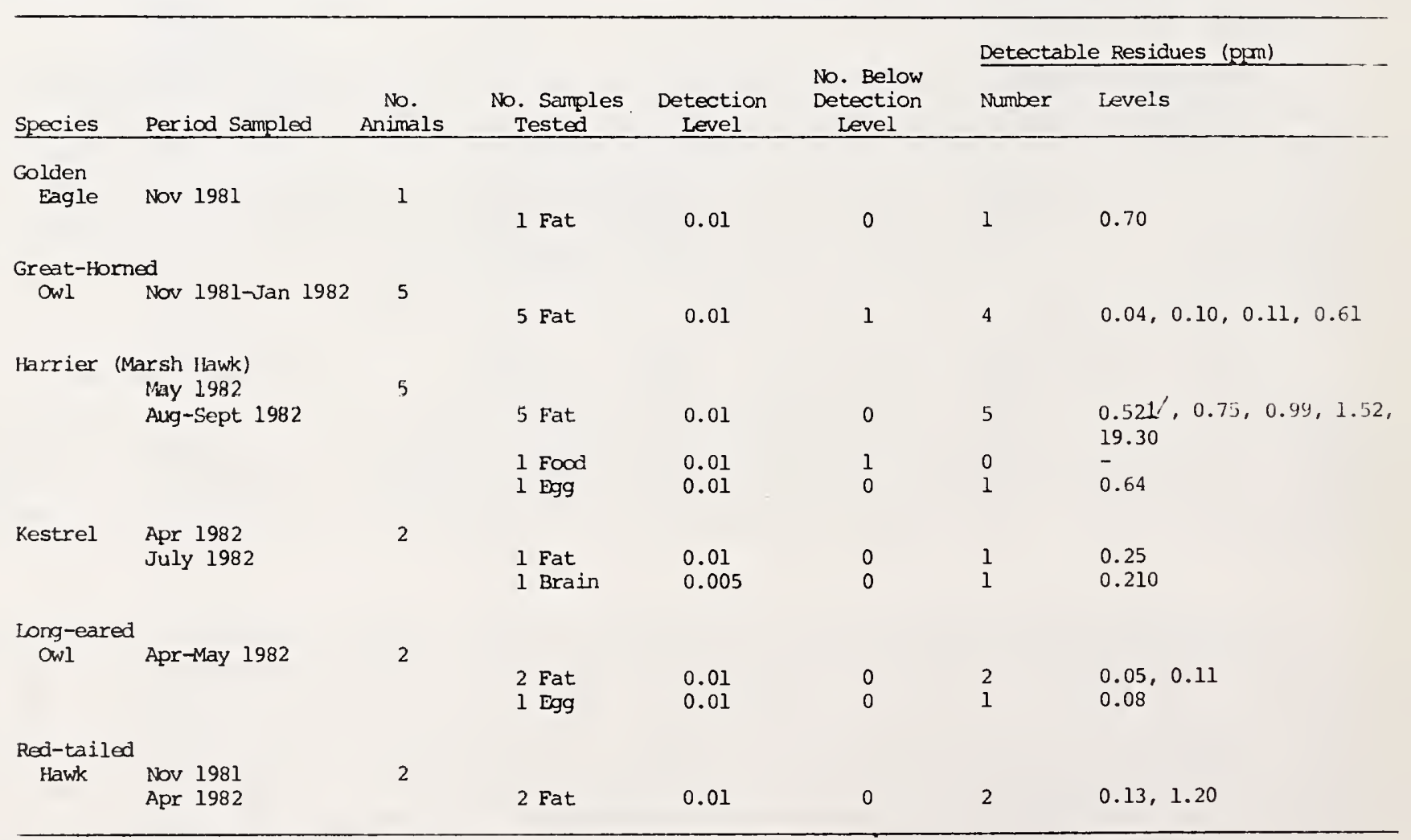

1) Also contained unchanged heptachlor. 
Table 32. Sumary of heptachlor epoxide residues detected in tissues of passerine birds in :bntana, $1981-1982$.

\begin{tabular}{|c|c|c|c|c|c|c|c|}
\hline \multirow[b]{2}{*}{ Species } & \multirow{2}{*}{$\begin{array}{l}\text { Period } \\
\text { Sampled }\end{array}$} & \multirow[b]{2}{*}{$\begin{array}{c}\text { No. } \\
\text { Animals }\end{array}$} & \multirow[b]{2}{*}{$\begin{array}{c}\text { No. Samples } \\
\text { Tested }\end{array}$} & \multirow[b]{2}{*}{$\begin{array}{l}\text { Detection } \\
\text { Ievel }\end{array}$} & \multirow[b]{2}{*}{$\begin{array}{l}\text { No. Below } \\
\text { Detection } \\
\text { Level }\end{array}$} & \multicolumn{2}{|c|}{ Detectable Residues (pgm, wet weight) } \\
\hline & & & & & & Number & Levels \\
\hline $\begin{array}{l}\text { Chestnut- } \\
\text { ollared } \\
\text { Longspur }\end{array}$ & Apr 1982 & 2 & $\begin{array}{l}2 \text { Whole Body } \\
\text { I Brain }\end{array}$ & $\begin{array}{l}0.005 \\
0.01\end{array}$ & $\begin{array}{l}1 \\
1\end{array}$ & $\begin{array}{l}1 \\
0\end{array}$ & $\begin{array}{l}0.130 \\
-\end{array}$ \\
\hline Cliff Swallow & July 1982 & 3 & $\begin{array}{l}3 \text { Whole Body } \\
\text { I Brain } \\
3 \text { Fat }\end{array}$ & $\begin{array}{l}0.005 \\
0.005 \\
0.01\end{array}$ & $\begin{array}{l}0 \\
1 \\
0\end{array}$ & $\begin{array}{l}3 \\
0 \\
3\end{array}$ & $\begin{array}{l}0.007,0.008,0.010 \\
- \\
0.06,0.11,0.19\end{array}$ \\
\hline Cowbird & May 1982 & 1 & 1 Fat & 0.01 & 0 & 1 & 0.02 \\
\hline Horned Lark & $\begin{array}{l}\text { Nov } 1931 \\
\text { pr-Sept } 1982\end{array}$ & 82 & $\begin{array}{l}53 \text { Whole Body } 1 / \\
27 \text { Brain } \\
27 \text { Fat } \\
3 \text { Egg }\end{array}$ & $\begin{array}{l}0.01 \\
0.01\end{array}$ & $\begin{array}{l}23 \\
12\end{array}$ & $\begin{array}{r}4 \\
15\end{array}$ & $\begin{array}{l}0.005,0.005,0.005,0.007,0.010, \\
0.010,0.010,0.016,0.110,0.110, \\
0.450,0.900,1.260 \\
0.005,0.02,0.23,0.25 \\
0.01,0.02,0.02,0.02,0.03,0.04, \\
0.06,0.06,0.06,0.07,0.09,0.12, \\
0.96,1.63,15.00 \\
0.020,0.041\end{array}$ \\
\hline $\begin{array}{l}\text { Lapland } \\
\text { Longspur }\end{array}$ & Nov 1981 & 1 & 1 Whole Body & 0.005 & 0 & 1 & 0.005 \\
\hline $\begin{array}{l}\text { Loggerhead } \\
\text { Shrike }\end{array}$ & May 1982 & 1 & $\begin{array}{l}1 \text { Brain } \\
1 \text { Fat }\end{array}$ & $\begin{array}{l}0.01 \\
0.01\end{array}$ & $\begin{array}{l}1 \\
0\end{array}$ & $\begin{array}{l}0 \\
1\end{array}$ & $\overline{0} .24$ \\
\hline $\begin{array}{l}\text { McCown's } \\
\text { Longspur }\end{array}$ & $\begin{array}{l}\text { Apr } 1982 \\
\text { Sept } 1982\end{array}$ & 7 & $\begin{array}{l}6 \text { Whole Body } \\
3 \text { Brain } \\
2 \text { Fat }\end{array}$ & $\begin{array}{l}0.005 \\
0.01 \\
0.01\end{array}$ & $\begin{array}{l}5 \\
2 \\
2\end{array}$ & $\begin{array}{l}1 \\
1 \\
0\end{array}$ & $\begin{array}{l}0.490 \\
0.09 \\
-\end{array}$ \\
\hline Meadowlark & $\begin{array}{c}\text { Apr-May } 1982 \\
\text { Sept } 1982\end{array}$ & 4 & $\begin{array}{l}4 \text { Brain } \\
4 \text { Fat }\end{array}$ & $\begin{array}{l}0.01 \\
0.01\end{array}$ & $\begin{array}{l}4 \\
2\end{array}$ & $\begin{array}{l}0 \\
2\end{array}$ & $\overline{0} .02,0.17$ \\
\hline $\begin{array}{l}\text { Red-winged } \\
\text { Blackbird }\end{array}$ & :av 1992 & 1 & $\begin{array}{l}1 \text { Brain } \\
1 \text { Fat }\end{array}$ & $\begin{array}{l}0.01 \\
0.01\end{array}$ & $\begin{array}{l}1 \\
1\end{array}$ & $\begin{array}{l}0 \\
0\end{array}$ & - \\
\hline Snow Bunting & Nov 1981 & 2 & $\begin{array}{l}2 \text { Whole Body } \\
\text { I Brain } \\
\text { I Fat } \\
\text { I Food }\end{array}$ & $\begin{array}{l}0.005 \\
0.01 \\
0.01 \\
0.005\end{array}$ & $\begin{array}{l}2 \\
1 \\
0 \\
1\end{array}$ & $\begin{array}{l}0 \\
0 \\
1 \\
0\end{array}$ & $\begin{array}{l}- \\
- \\
0.02\end{array}$ \\
\hline Vesper Sparrow & $\begin{array}{l}\text { Apr } 1982 \\
\text { July-Sept } 1982\end{array}$ & 10 & $\begin{array}{l}10 \text { Whole Body } \\
2 \text { Brain } \\
2 \text { Fat }\end{array}$ & $\begin{array}{l}0.005 \\
0.01 \\
0.01\end{array}$ & $\begin{array}{l}7 \\
0 \\
1\end{array}$ & $\begin{array}{l}3 \\
2 \\
1\end{array}$ & $\begin{array}{l}0.005,0.013,0.059 \\
0.01,0.52 \\
0.11\end{array}$ \\
\hline $\begin{array}{l}\text { White-crowned } \\
\text { Sparrow }\end{array}$ & May 1982 & 3 & $\begin{array}{l}3 \text { Whole Body } \\
\text { I Brain } \\
2 \text { Fat }\end{array}$ & $\begin{array}{l}0.005 \\
0.01 \\
0.01\end{array}$ & $\begin{array}{l}3 \\
1 \\
0\end{array}$ & $\begin{array}{l}0 \\
0 \\
2\end{array}$ & $\begin{array}{l}- \\
- \\
0.01,25.00\end{array}$ \\
\hline $\begin{array}{l}\text { Yellow-rumped } \\
\text { Warbler }\end{array}$ & May 1982 & 1 & I Whole Body & 0.005 & 0 & 1 & 0.049 \\
\hline
\end{tabular}

1/ Two others were tested for only endrin, dieldrin and PCB's because of possible internal contamination. 
Positive samples, sample sites, and HE residues in individually tested birds included: 9 of $11 \mathrm{killdeer}$ from Toole/Liberty Counties $(0.05-2.22 \mathrm{ppm}) ; 1$ of 8 Brewers blackbirds from Carbon/Stillwater Counties $(0.15 \mathrm{ppm})$; and 8 of 11 tree swallows from Gallatin/Park Counties $(0.06-0.55 \mathrm{ppm})$.

Species tested in pools, and pools tested per species, included: mourning dove, 4; cliff swallow, 4; killdeer, 3; meadow lark, 3; robin, 2; eastern kingbird, 2; spotted sandpiper, 1; and red-winged blackbird, 1. No spotted sandpiper, robin, or eastern kingbird pools contained HE residues. One pool of each of the other species tested contained HE as follows: mourning dove, $3.08 \mathrm{ppm}$; cliff swallow, $0.13 \mathrm{ppm}$; killdeer, $0.07 \mathrm{ppm}$; meadowlark, $0.05 \mathrm{ppm}$; and red-winged blackbird, $0.36 \mathrm{ppm}$. Pools positive for $\mathrm{HE}$ came from Toole/Liberty Counties (mourning dove, cliff swallow and red-winged blackbird) and Carbon/Stillwater Counties (killdeer and meadowlark). No HE was detected in pools tested from Lewis and Clark/Broadwater, Petroleum/Garfield, or Gallatin/Park Counties.

The 3 sample sites with positive HE residues appeared to represent 3 different situations regarding wildlife contamination. The Carbon/Stillwater County area showed fairly widespread, but low level contamination, compared to the Toole/Liberty County area which had widespread contamination at often very high levels. Both situations probably represented local HE contamination of wildlife. The Gallatin/Park County sample site showed a moderate level of HE contamination in one species, but no HE in 3 others. This was a high mountain sample site far removed from any cultivated areas, suggesting that tree swallows were contaminated elsewhere, probably on their wintering grounds.

\section{Miscellaneous Samples}

All of these samples ( 8 sediment, 2 each of barley, cutworm, snapping turtle fat, wheat, and 1 of snails) were collected on or near 1981 or 1982 endrin treated areas, and only 1 of the 17 samples tested had detectable levels of HE (0.01 ppm). That was a sample of several whole snails collected from a pond in Chouteau County, and indicated at least one mode of contamination for those species that include snails or other aquatic invertebrates in their diet.

\section{Discussion}

Unchanged heptachlor residues in animal tissues indicate recent ingestion. Its absence, however, does not rule this out since contaminated food sources may contain only the epoxide. The half life of heptachlor, when worked into the soil, is $7-12$ years (Brooks 1974b).

The detection of heptachlor and $H E$ in Montana wildife caused concern for 2 reasons: their toxicity to wildlife (see 
below); and their documented carcinogenicity in experimental laboratory animals (Train 1975, Environmental Protection Agency 1976, Federal Register 1976).

Toxicity of heptachlor and $H E$ to wildife is well documented, beginning in the late 1950's (Clawson and Baker 1959, Rosene et al. 1961, Ferguson 1964, Rosene 1965, Stickel et al. 1965, Kreitzer and Spann 1968). Most of those earlier studies dealt with fairly high heptachlor application rates and cannot be related to the situation under which heptachlor is used in Montana. However, recent studies in Oregon revealed that heptachlor seed treatments, at the same rate applied in Montana, were the causative factor in poisoning deaths of pheasants, black billed magpies, California quail, Canada geese, and a golden eagle; HE residues in eggs of Canada geese also caused lowered reproductive success of this species (Blus et al. 1979). A subsequent study in that area further established that American kestrels were accumulating $\mathrm{HE}$ residues in eggs and body tissues at levels which reduced reproductive success and caused some adult mortality (Henny et al., in press). In a companion study, Henny et al. (in prep.) reported 3 additional golden eagles and a rough-legged hawk poisoned by $H E$, and HE residues were found in eggs of 5 species of hawks and 4 of 5 species of owls sampled. The data in the latter study was too limited to determine whether residue levels in eggs were high enough to cause reproductive failures among the several species tested.

The greatest amount of available data on HE levels in wildlife has come from samples tested as part of the National Pesticide Monitoring Program initiated in the mid-1960's. Terrestrial wildlife periodically sampled under this program include mallards and black ducks, starlings, and bald eagles from throughout the United States (Johnson et al. 1967).

Montana big game samples tested for HE were limited in number, and showed a relatively low incidence of occurrence and relatively low residue levels. Greenwood et al. (1967) found no detectable $\mathrm{HE}$ in 47 fat samples of South Dakota mule and whitetailed deer, pronghorn, or elk (Cervus elaphus). However, later studies found $\mathrm{HE}$ in the fat of $55 \%$ of 45 pronghorns, and in all 13 mountain goats (Oreamnos americanus) tested from South Dakota (Moore et al. 1968, Boddicker et al. 1971).

At the time our samples were collected the only registered use of heptachlor was as a seed dressing. It had previously been used more widely, including for rangeland grasshopper control, which would have led to more widespread contamination of big game habitats than seed treatments. Heptachlor and HE are present in small amounts in wheat plants grown from heptachlor treated seed (Burrage and Saha 1967). These plants, plus treated seed spilled or left exposed during planting, would constitute the major source of contamination for Montana big game. Big game would not be expected to eat much treated grain because it would seldom be available in large quantities. Therefore, plants growing from treated seed would be the primary source of HE, but at very low 
levels. This would explain the low residue levels we found in the few big game animals tested for HE.

Residues of HE occurred in over one-fourth of the upland bird samples tested from Montana. Most residues were relatively low, but a few exceeded action levels. Linder and Dahlgren (1970) and Anderson et al. (1970) found HE residues in tissues of approximately $70 \%$ and $75 \%$ of South Dakota and Illinois pheasants tested, respectively. Fifty to $90 \%$ of the pheasant eggs tested in various studies have contained HE (Greenberg and Edwards 1970, Johnson et al. 1970, and Linder and Dahlgren 1970). The same sources of contamination exist for upland birds as big game, but because they are highly granivorous, birds probably obtain most of their HE from treated grain. Higher residues on seeds would account for the occasional high residue levels found in bird tissues.

No studies that sampled large numbers of small mammals were located, so the significance of our findings, in terms of effects on those species, is unknown. Because small mammals are not highly mobile, our results do indicate widespread contamination of Montana habitats, and a potential impact on predators consuming $\mathrm{HE}-$ contaminated species.

Species categorized as other aquatic or migratory game birds will not be treated separately here. The discussion for waterfowl and passerines should be applicable to those other species as well.

Results from duck wings tested in the National Pesticide Monitoring Program (each sample consisted of a 25-wing pool from 1 state) have not been presented by individual states, and generally have not included levels found in individual pools. Further, residue levels in individual birds are not reported. Nonetheless, HE occurred in most or all samples from the 1969-1970 and 1972-1973 hunting seasons (Heath and Hill 1974, White and Heath 1976 ).

While more recent duck wing samples have shown a declining frequency of occurrence of $\mathrm{HE}$ (White 1979b, Cain 1981), those from 1979-1980 still included $30 \%$ and $23 \%$ positive for HE in the Central and Pacific Flyways, respectively. Data from 1981-1982 showed a further decline in the incidence of $\mathrm{HE}$ in Central Flyway samples, but an increase in the mean concentration level (FWS unpublished data). Pacific Flyway data (1981-1982) was inconplete, but the incidence of $\mathrm{HE} \mathrm{(20 \% )} \mathrm{was} \mathrm{similar} \mathrm{to} \mathrm{that} \mathrm{in} \mathrm{1979-}$ 1980. One of the two 1981-1982 duck wing samples from the Central Flyway portion of Montana was positive for HE, while 6 samples from the Pacific Flyway portion contained no detectable HE residues.

Besides the frequency of occurrence of HE, several differences occurred between the fall 1981-1982 duck wing samples and our spring-fall 1982 samples (different tissues sampled, individual birds versus pools, and different reporting bases). Thus, 
comparisons between them would be only conjectural at this time. However, those data further documented widespread HE contamination in Montana.

Some waterfowl species which rarely venture onto land (e.g. ruddy duck) had elevated $\mathrm{HE}$ levels in summer, suggesting contamination of aquatic environments, probably by runoff from nearby fields sown with treated seed.

Vermeer and Reynolds (1970) reported up to 0.9 ppm HE (wet weight) in mallard eggs ( 10 eggs per sample) from southern Saskatchewan, far below the maximum level (6.98 ppm) we found in mallard eggs. Overall, they reported $H E$ residues in 40 of $41 \mathrm{egg}$ samples representing 7 species of aquatic birds from Alberta, Saskatchewan and Manitoba.

Starlings have been sampled periodically from 4 Montana sites as part of the National Pesticide Monitoring Program; sites included areas in eastern, southcentral, and western Montana. Although reporting levels varied between sampling periods, most Montana starling samples (normally 10 whole bodies pooled together, occasionally fewer birds) contained small amounts of HE (Martin 1969, Martin and Nickerson 1972, Nickerson and Barbehenn 1975, White 1976 and 1979a). Variations in HE residues between sampling periods at the same sites in Montana were not consistently in one direction. The reporting level in the last sampling period (1976) was higher than in most previous periods, making it difficult to detect whether HE residues were increasing or decreasing at 2 sample sites. Residue levels at 1 of the 2 remaining sites were higher in 1976 than in any previous year, while those at the other were lower.

The starling data generally agree with our current passerine data in that both showed widespread availability of heptachlor/HE in Montana. Recently tested whole body samples of Montana birds, both individuals and pools, had significantly higher HE residues than any of the Montana starling pools. Those residues were apparently obtained locally. High residues could impact locally breeding populations of those raptor species which include a high percentage of passerine birds in their diets.

Carcasses of bald eagles, including only a few from Montana, have been tested for contaminants since 1964 (Reichel et al. 1969, Mulhern et al. 1970, Belisle et al. 1972, Cromartie et al. 1975, Prouty et al. 1977, and Kaiser et al. 1980). Overall, 55\% of the bald eagles tested have been positive for HE (range of 38$79 \%$ between sample periods). Maximum residues (wet weight) found in 3 sampling periods during 1964-1970, were 0.8 ppm or less, while maximum residues reported from 3 sampling periods during 1971-1977 ranged from 2.0 to $5.5 \mathrm{ppm}$. Although there was no consistent trend between sampling periods, the continued high frequency of occurrence, and high carcass residues of $\mathrm{HE}$ in some eagles, reflect the widespread environmental contamination by this compound. This is in general agreement with our findings on HE residues in raptors. 
The occurrence of HE in both raptor egg samples we tested $(0.08$ and $0.64 \mathrm{ppm})$ closely agreed with results obtained from Montana raptor eggs tested by Seidensticker and Reynolds (1971). They reported HE residues in all eggs tested ( 5 red-tailed hawk and 3 great horned owl) at levels of 0.02-0.80 ppm.

Effects on Wildlife. Effects of organochlorine insecticides can range from inconspicuous and subtle changes, such as in behavior, to conspicuous and often dramatic die-offs of larger vertebrates.

Direct mortality is the most obvious of several potential effects of pesticides on wildlife. While die-offs of fish and some other aquatic species are fairly obvious, direct mortality of terrestrial wildiife is difficult to detect, even through searches, unless it involves rather heavy losses (Rosene and Lay 1963).

Use of heptachlor, aldrin, and dieldrin as seed dressings on spring-sown cereal grains led to widespread casualties of birds [wood pigeons (Columba palumbus), Hungarian partridge, pheasants, and other species] in the United Kingdom in the late 1950's. There was also circumstantial evidence of secondary poisoning of foxes (Vulpes spp.), badgers (Meles spp.), and farm dogs and cats (Turtle et al. 1963). That mortality resulted in the banning of those chemicals as seed treatments on spring-sown grains in 1962. The Netherlands imposed a similar ban on the use of those chemicals in 1968. This ban was extended to also include fall-sown grains following widespread mortality of raptors in the winter of 1968-1969 (cf Environmental Protection Agency 1976, Blus et al. 1979).

The major use of heptachlor in North America in recent years has been as a seed treatment. Feeding trials in Canada, with heptachlor and lindane treated seed given to pheasants, revealed that ingestion of as few as 5 seeds per day for 15 days led to unacceptable HE residues in the body fat (Burrage and Saha 1972). Based on those findings, they recommended that the use of heptachlor as a seed dressing be discontinued and replaced with lindane, which appeared less hazardous to seed-eating birds.

Another recommendation to ban the use of heptachlor as a seed dressing (along with aldrin, and to take effect on 1 January 1974) resulted from findings of significantly increased residues of those chemicals in seed-eating birds and mammals in the prairie provinces of Canada. Those prey species were considered the major source of HE residues found in eggs of the prairie falcon (maximum of $7.04 \mathrm{ppm}$ ) and merlin (maximum of $4.63 \mathrm{ppm}$ ) (Fyfe 1973 from EPA 1976). Heptachlor epoxide has also been implicated in direct mortality of these 2 species of raptors (Fyfe et al. 1969, Henny et al. 1976).

Results of Oregon studies showing direct mortality of many species of birds, including upland game birds, waterfowl, and 
raptors, from the use of heptachlor as a seed treatment were briefly reviewed earlier. There are no known instances of direct mortality attributable to the use of heptachlor in Montana. However, documented wildlife mortality following similar use in a number of other areas, coupled with residue levels found in several species of Montana birds and small mamals, suggested that such losses have probably occurred on a small scale in at least some areas of the state, especially among raptors.

Another potentially lethal aspect of heptachlor use was reported by Heinz and Johnson (1981). They demonstrated that dieldrin, and possibly other organochlorine pesticides, caused birds to enter into an irreversible starvation process which ended in death. Residue levels in brains that averaged about half the lethal concentration, and as low as 10-15\% in highly sensitive individuals, caused cowbirds to stop eating, mobilize dieldrin to the brain and die. Thus, living animals that are collected and analyzed may have all the appearances (physical and from residue levels) of healthy specimens and yet be lethally affected. If this holds true for $\mathrm{HE}$, some of our deer mouse and mourning dove specimens could have been at or near those levels. Because few brains were sampled from most groups of animals, other species having high $\mathrm{HE}$ levels in fat may have contained potentially dangerous levels in brains as well.

The EPA gave notice of its intent to cancel all registered uses of heptachlor and chlordane in November 1974 (Federal Register 1976). Cancellation subsequently began on 1 September 1982. In addition, existing stocks of heptachlor formulated prior to 2 June 1982 could be used until exhausted. The MDA estimated in summer 1982 that a 3-year supply of heptachlor existed in a several state area that included Montana. Approximately 3 times as many acres in Montana are seeded with lindanetreated seed as compared to heptachlor-treated seed; approximately 177,000 acres were seeded with the latter in Montana in 1981. Thus, widespread HE contamination found in Montana wild If e in 1981-1982 is expected to continue for several more years.

Sublethal effects of $\mathrm{HE}$ are considered here to include delayed mortality precipitated by other factors, increased neonatal mortality of offspring of contaminated parents, reduced reproductive performance, and changes (behavioral, physiological, etc.) which might predispose animals to mortality from other, often more obvious, causes.

Stress-induced delayed mortality from dietary levels of pesticides not immediately lethal, or long after exposure to the chemical has been terminated, has been widely documented. Mortality associated with food deprivation and weight loss, following termination of dietary DDT dosage of house sparrows, was reported by Bernard (1963). He also suggested that birds might store sublethal pesticide residues in body fat for some length of time, eventually succumbing when those reserves were utilized. 
Van Velzen et al. (1972) included DDT in the diet of cowbirds for 13 days, then returned them to clean feed. Treated birds were subsequently subjected to food restriction resulting in weight loss, which resulted in typical DDT poisoning up to 4 months after treatment. Stickel (1965) reported disturbanceinduced mortality of DDT-dosed cowbirds for at least 4 weeks after dosage ceased.

Response of rats in acute oral dosing experiments was also increased by disturbance, while protecting them from disturbance delayed or diminished the response (Deichman et al. 1950, in Stickel 1965). Mortality of cold-stressed rats was more rapid among DDT-dosed animals than untreated controls (de Freitas et al. 1969).

Van Velzen et al. (1972) and Stickel (1973) reviewed several additional studies which reported similar mortality among several species of birds, as well as rats and laboratory mice, that was associated with weight loss during or at some time after the termination of dosing.

These and other studies suggested that any stress-induced mobilization of body fat reserves may result in similar mortality among animals with normally sublethal residue levels, or at some time after exposure has occurred. Additional stress factors could include migration, cold weather, reproduction, disease, injury, and others. Mortality associated with reproduction and molt has been reported for DDE-dosed kestrels (Porter and Wiemeyer 1972), while coturnix quail fed DDT for 6 months with no mortality and then stressed by artificially reduced day length, accompanied by molt and presumed weight loss, suffered substantial mortality (Stickel and Rhodes 1970). Similarly, a wild, HE poisoned merlin was hypothesized to have mobilized fat reserves during fall migration, resulting in its death (Henny et al. 1976).

The above suggests that mortality far removed from the site of pesticide application in time and/or space, can occur. Such mortality, if detected at all, would not normally be associated with the underlying cause of death.

Although most of the studies reported here have involved DDT or its metabolites, the same mechanism would be involved with most other organochlorine insecticides which are also highly lipophilic, including $\mathrm{HE}$.

Reduced reproductive performance can result from failure in any part of the reproductive process prior to independence of the young and their recruitment into the population; this includes neonatal mortality. Cummings et al. (1966, 1967) studied the accumulation and loss of pesticides in eggs and other tissues of laying hens. They fed a combination of DDT, lindane, heptachlor epoxide, dieldrin, and endrin at levels of $0.05,0.15$, and 0.45 ppm for 14 weeks, followed by untreated feed for 30 days. Within 3 days after pesticide feeding began residues of all chemicals 
appeared in eggs. Residue levels of all chemicals in eggs, fat, muscle, and liver increased sharply at the start of the feeding trials, followed by a gradual approach to an approximate plateau. However, residues of $\mathrm{HE}$ in fat may not have been maximized by the end of the 14 week feeding period. HE and dieldrin plateaued in eggs at approximately the levels in feed; levels in fat plateaued at about 10 times that in feed. Residues in eggs and other body tissues showed a continual decline after the birds were returned to clean feed. However, in only $1 \mathrm{case}$ (lindane in eggs at the 0.05 level) had residues in eggs or fat returned to the back ground level within the 30-day withdrawal period. Muscle and liver residues were more variable; some chemicals did not appear above background levels in muscle, while the decline in livers did not permit a reliable estimate of the rate of decline.

Sauter and Steele (1972) fed clean feed to groups of chickens for 10 weeks, then switched them to diets containing DDT, diazinon, lindane or malathion at $0.1,1.0$, or 10.0 ppm for an additional 10 weeks. Egg production for all test groups declined from pretest levels. Eggs from treated groups and a control group were incubated beginning on the third day of treatment and at weekly intervals thereafter. Hatchability was significantly reduced below that of controls for all treatments except malathion at $0.1 \mathrm{ppm}$. Embryonic mortality in the first 7 days of incubation was significantly higher than controls for all levels of DDT, 1.0 and $10.0 \mathrm{ppm}$ lindane, and $10.0 \mathrm{ppm}$ malathion and diazinon. Embryonic death in days 8-21 increased in all groups but 0.1 ppm malathion.

Because heptachlor is more toxic (has a lower $\mathrm{LC}_{50}$ ) than any of these compounds to bobwhite quail, pheasants and mallards (Heath et al.1972b) and is an organochlorine insecticide, it and HE would probably act in a similar fashion. Blus et al.(1979), in Oregon, found that HE residues in eggs of Canada geese were correlated with nest success. Success was high (95\%) in nests having sample eggs with $1.0 \mathrm{ppm}$ or less of $\mathrm{HE}$, declining to only $20 \%$ in nests with eggs that contained $10.0 \mathrm{ppm}$ or more.

In a subsequent investigation in the same area, Henny et al. (in press) determined that kestrels were more sensitive to HE residues in eggs than Canada geese. Reduced productivity of kestrels occurred when $1.5 \mathrm{ppm}$ or more of HE was present in eggs. Total failures of kestrel nesting were due to failure of clutches of eggs to hatch and complete mortality of broods during the first week. Since goslings leave the nest shortly after hatching, some complete mortality of goose broods due to HE contamination could have gone undetected by Blus et al. (1979), and their nest success figures must be regarded as absolute maximums. The level of $\mathrm{HE}$ found in one of our mallard egg samples $(6.98 \mathrm{ppm}$ wet weight, 2-egg composite sample) was in the range (5.1-10.0 ppm) which resulted in only $67 \%$ nest success (Blus et al. 1979).

Long-term feeding of heptachlor to rats resulted in a striking reduction in litter size in successive generations as well as 
significant neonatal mortality, especially in the first $24-48$ hours (Mestitzova 1967). She also reported an increased incidence of cataracts of the lens in both the offspring and the parent rats.

The preceding review suggested that heptachlor seed treatment has resulted in decreased reproductive performance by birds (at least among waterfowl and raptors) in portions of Montana. Some small mammal species could have been similarly affected.

Stadelman et al. (1965) orally dosed groups of chickens with DDT, dieldrin, lindane, and heptachlor for 5 days at levels approximating 10-15 ppm in the diet. Fat and eggs of those groups of birds were tested at 1, 5, 10, 17, and 26 weeks following the end of treatment. Peak HE levels occurred in fat at 1 week, and in eggs at 5 weeks, posttreatment. Residues of HE persisted in both fat and eggs through the entire 26 week posttreatment duration of theirstudy. Thus, low HE residues found in eggs do not necessarily indicate recent exposure to heptachlor and/or HE; birds contaminated in October and November, following fall seeding, could retain HE residues in fat and pass it on to eggs at least into April and May. However, high levels of $\mathrm{HE}$ in eggs would indicate recent ingestion.

Other sublethal effects of pesticide exposure affecting survival of wildlife have been documented for many organochlorine insecticides. These include mild neurological disorders (Hill et al. 1971), behavioral changes (Baxter et al. 1969, James and Davis 1965, McEwen and Brown 1966, and others), visual deficits (Revzin 1966), impaired reflex conditions (Friend and Trainer 1970a) and others.

Reduced wariness, decreased mobility, or delayed migratory movements related to one or more of the above could result in mortality from a variety of factors. Prey animals that do not respond quickly and correctly to predators are more likely to be captured than those not so affected. On the other hand, predators could be affected sufficiently so that their efficiency at capturing prey was reduced to the point that they could no longer maintain themselves.

Hypersensitivity and exaggerated response to sudden stimuli, such as noise or movement, are often the earliest observable symptoms of exposure to organochlorine insecticides (Radeleff 1964). Such responses could predispose wildlife to predation, or result in a negative energy balance leading to death.

Another ultimately lethal effect of sublethal exposure to organochlorine insecticides is suppression of the immune response as reported by Friend and Trainer (1970a). They found that mallard ducklings with sublethal levels of DDT or dieldrin suffered 6 to 9 times greater mortality than untreated controls when challenged with duck hepatitis virus. 
If detected at all, wildife mortality resulting from any of the above factors would probably be attributed to the proximal cause, with the true nature of the underlying causal factor going unsuspected.

Effects on Humans. The relationship of heptachlor and HE to human health will be only briefly reviewed. We have relied on an EPA report (Environmental Protection Agency 1976) for most of the information discussed here.

Market basket surveys from fiscal years 1973 and 1974 indicated HE commonly occurred in dairy products and meat, fish, and poultry.

Studies of human tissues from many areas of the world indicate widespread distribution of HE, including residues in fetuses, demonstrating transferral across placental membranes. Numerous studies have also detected HE in human milk samples from widely scattered areas of the world.

Potential carcinogenicity of heptachlor and $H E$ has been covered in sone detail, including discussion of the relationship between carcinogenicity in mice versus that in humans (Federal Register 1976). Available data indicate that technical grade heptachlor is carcinogenic in laboratory animals (Envjronmenta]. Protection Agency 1976) and therefore probably in humans as well. While the EPA did not foresee either acute or teratogenic hazards resulting from people eating Montana's HE-contaminated game birds, they feel that potentially chronic liver effects and carcinogenic risks could result from ingestion of such birds (undated corresp., E.L. Johnson, Director of EPA Office of Pesticide Programs to G.L. Gingery, MDA). This letter further states that because HE js carcinogenic, the concept of ADI's no longer applies to this compound.

Polychlorinated Biphenyls (PCB's)

PCB residue levels were also found during tests for residues of endrin and other chlorinated hydrocarbon compounds in wildlife tissues during 1981-1982. PCB levels varied between species, between groups of species, and with the kinds of tissues. All were obtained in ppm on a wet weight basis. The USDA action level for PCB's in domestic meats is 5.0 ppm on a lipid weight basis.

Resident_WildIife

Big Game. None of the fat samples from 5 pronghorns, 2 mule deer, or 4 white-tailed deer contained detectable levels of PCB'S during August 1981-July 1982. No detectable PCB was found in the 
single brain sample from a male fawn white-tailed deer. Detection levels for all big game tissues were $0.10 \mathrm{ppm}$. The limited sampling for these species precluded any conclusions concerning PCB-contamination of big game.

Upland Game Birds. Only the fat from an adult female sharptailed grouse collected in Richland County in July 1982 contained detectable PCB; that sample contained $0.14 \mathrm{ppm}$, whereas the PCB detection limit for all tissues was $0.10 \mathrm{ppm}$. Although sharptailed grouse (33 fat, 2 meat, 1 brain, and 1 food) and pheasants (16 fat and $1 \mathrm{egg}$ ) were represented reasonably well in the sampling process, Hungarian partridge ( 6 fat), sage grouse ( 1 fat), and Merriam turkey (1 liver) were not, and no conclusion was made concerning their relationships to PCB's.

Small Mammals. Varying combinations of whole bodies, fat, brain, and liver tissues, plus food (contents of cheek pouches) and a few embryos from 12 species of small mammals were tested for PCB's. With the exception of some deer mice and a blacktailed prairie dog, PCB residues did not exceed detection limits (Table 33). PCB's were detected in both sexes, and in subadults as well as adults, in whole bodies of deer mice.

Each of the mice positive for PCB was taken as part of the 1982 alternative insecticide-wildlife field studies in Golden Valley and Musselshell Counties. Each month, except February, March, and October was represented in the sampling.

The single black-tailed prairie dog, with 0.036 ppm PCB in its brain, was a juvenile male that was hand-caught while exhibiting symptoms of endrin intoxication.

\section{Migratory Wildlife}

Waterfow l. Only 1 fat sample from Canada geese $(N=33)$ and none of the fat from 4 whistling swans contained detectable PCB residues. However, each of the 10 duck species yielding tissues for testing, except ruddy duck, contained detectable PCB's. Forty of 154 fat, 2 of 8 brain, 2 of 12 meat, and 2 of 8 food samples yielded detectable PCB residues (Table 34). Contents of 2 eggs, and the single cooked meat sample lacked detectable $P C B^{\prime} \mathrm{S}$.

Generally, duck species which feed primarily in aquatic environments reflected higher frequency of PCB contamination in their fat than did species which also feed in grainfields. The highest PCB residue in fat was $50.10 \mathrm{ppm}$ from an adult male bluewinged teal taken in Dawson County in May 1982 (Table 34); bluewinged teal were the field/aquatic species with the highest percentage of PCB contaminated tissues ( $41 \%$ of 17 samples). 
Table 3.3. Sumarv of PCB residues detected in tissues of st:all mamals in iontana, $1901-1932$.

\begin{tabular}{|c|c|c|c|c|c|c|c|}
\hline Species & $\begin{array}{l}\text { Period } \\
\text { Sampled }\end{array}$ & $\begin{array}{l}\text { No. } \\
\text { Animals }\end{array}$ & $\begin{array}{l}\text { ik. } \\
\text { Samples } \\
\text { Tested }\end{array}$ & $\begin{array}{l}\text { Detection } \\
\text { Level }\end{array}$ & $\begin{array}{l}\text { No. Below } \\
\text { Detection } \\
\text { Level }\end{array}$ & \multicolumn{2}{|c|}{$\frac{\text { Detectable Residues (ppm) } 1 \text { I/ }}{\text { No. }}$} \\
\hline $\begin{array}{l}\text { Black-tailed } \\
\text { Prairie Dog }\end{array}$ & $\begin{array}{c}\text { June-Aug } \\
1982\end{array}$ & 6 & $\begin{array}{l}5 \text { fat } \\
6 \text { brain } \\
4 \text { liver }\end{array}$ & $\begin{array}{l}0.01 \\
0.01 \\
0.01\end{array}$ & $\begin{array}{l}5 \\
5 \\
4\end{array}$ & $\begin{array}{l}0 \\
1 \\
0\end{array}$ & 0.036 \\
\hline $\begin{array}{l}\text { Cottontail } \\
\text { Rabbit }\end{array}$ & $\begin{array}{l}\text { Jan, Sept } \\
1982\end{array}$ & 2 & $\begin{array}{ll}2 & \text { fat } \\
1 & \text { brain } \\
1 & \text { liver }\end{array}$ & $\begin{array}{l}0.10 \\
0.01 \\
0.01\end{array}$ & $\begin{array}{l}2 \\
1 \\
1\end{array}$ & $\begin{array}{l}0 \\
0 \\
0\end{array}$ & $\begin{array}{l}-- \\
--\end{array}$ \\
\hline Deer Mouse & $\begin{array}{l}\text { Nov } 1981 \\
\text { Aupr-Sept } 1982\end{array}$ & $\begin{array}{r}124 \\
16 \\
5\end{array}$ & $\begin{array}{l}77 \text { whole } \\
43 \text { brain } \\
42 \text { liver } \\
3 \text { enbryo } \\
1 \text { newborn }\end{array}$ & $\begin{array}{l}0.05 \\
0.10 \\
0.10 \\
0.05 \\
0.05\end{array}$ & $\begin{array}{r}73 \\
41 \\
41 \\
3 \\
1\end{array}$ & $\begin{array}{l}4 \\
2 \\
1 \\
0 \\
0\end{array}$ & $\begin{array}{l}0.10,0.56,0.58, \\
0.71,0.18 \\
0.062,0.22 \\
\ldots \\
-\end{array}$ \\
\hline House Mouse & Nov 1981 & 3 & $\begin{array}{l}3 \text { whole } \\
1 \text { brain } \\
1 \text { liver }\end{array}$ & $\begin{array}{l}0.05 \\
0.10 \\
0.10\end{array}$ & $\begin{array}{l}3 \\
1 \\
1\end{array}$ & $\begin{array}{l}0 \\
0 \\
0\end{array}$ & $\begin{array}{l}-- \\
-- \\
--\end{array}$ \\
\hline Harvest Mouse & Nov 1981 & 7 & $\begin{array}{l}6 \text { whole } \\
2 \text { brain } \\
2 \text { liver }\end{array}$ & $\begin{array}{l}0.05 \\
0.10 \\
0.10\end{array}$ & $\begin{array}{l}6 \\
2 \\
2\end{array}$ & $\begin{array}{l}0 \\
0 \\
0\end{array}$ & $\begin{array}{l}-- \\
-- \\
--\end{array}$ \\
\hline Meadow Vole & $\begin{array}{l}\text { Nov } 1981 \\
\text { Apr-May } 1982\end{array}$ & 16 & $\begin{array}{r}11 \text { whole } \\
5 \text { brain } \\
5 \text { liver }\end{array}$ & $\begin{array}{l}0.05 \\
0.10 \\
0.10\end{array}$ & $\begin{array}{r}11 \\
5 \\
5\end{array}$ & $\begin{array}{l}0 \\
0 \\
0\end{array}$ & $\begin{array}{l}-- \\
-- \\
--\end{array}$ \\
\hline Pocket Mouse & Nov 1981 & 1 & 1 whole & 0.05 & 1 & 0 & $\rightarrow$ \\
\hline Porcupine & May 1.982 & 1 & $1 \mathrm{fat}$ & 0.10 & 1 & 0 & $-\infty$ \\
\hline Prairie Vole & Nov. 1981 & 3 & $\begin{array}{ll}3 & \text { whols } \\
1 & \text { brain } \\
1 & \text { liver }\end{array}$ & $\begin{array}{l}0.05 \\
0.10 \\
0.10\end{array}$ & $\begin{array}{l}3 \\
1 \\
1\end{array}$ & $\begin{array}{l}0 \\
0 \\
0\end{array}$ & $\begin{array}{l}-- \\
--\end{array}$ \\
\hline $\begin{array}{l}\text { Richardson's } \\
\text { Ground Squirrel }\end{array}$ & Apr 1982 & 3 & $\begin{array}{l}3 \text { fat } \\
3 \text { brain } \\
3 \text { liver } \\
1 \text { food }\end{array}$ & $\begin{array}{l}0.10 \\
0.10 \\
0.10 \\
0.05\end{array}$ & $\begin{array}{l}3 \\
3 \\
3 \\
1\end{array}$ & $\begin{array}{l}0 \\
0 \\
0 \\
0\end{array}$ & $\begin{array}{l}-- \\
-- \\
-- \\
--\end{array}$ \\
\hline $\begin{array}{l}\text { Thirteen-lined } \\
\text { Ground Squirrel }\end{array}$ & May 1982 & 2 & $\begin{array}{l}2 \text { fat } \\
2 \text { brain } \\
2 \text { liver } \\
1 \text { food }\end{array}$ & $\begin{array}{l}0.10 \\
0.10 \\
0.10 \\
0.05\end{array}$ & $\begin{array}{l}2 \\
2 \\
2 \\
1\end{array}$ & $\begin{array}{l}0 \\
0 \\
0 \\
0\end{array}$ & $\begin{array}{l}-- \\
-- \\
-- \\
--\end{array}$ \\
\hline $\begin{array}{l}\text { White-tailed } \\
\text { Jackrabbit }\end{array}$ & $\begin{array}{l}\text { Apr, May, } \\
\text { July } 1982\end{array}$ & 5 & $\begin{array}{l}5 \text { fat } \\
3 \text { brain } \\
3 \text { liver }\end{array}$ & $\begin{array}{l}0.10 \\
0.05 \\
0.05\end{array}$ & $\begin{array}{l}5 \\
3 \\
3\end{array}$ & $\begin{array}{l}0 \\
0 \\
0\end{array}$ & $\begin{array}{l}-- \\
-- \\
--\end{array}$ \\
\hline
\end{tabular}

1/ Primarily wet weight basis, but a few may be expressed on a lipid basis. 
Tahle 34. Surramy of PCD residues cietected in tissues of raterforl in iontana, 1031-1962.

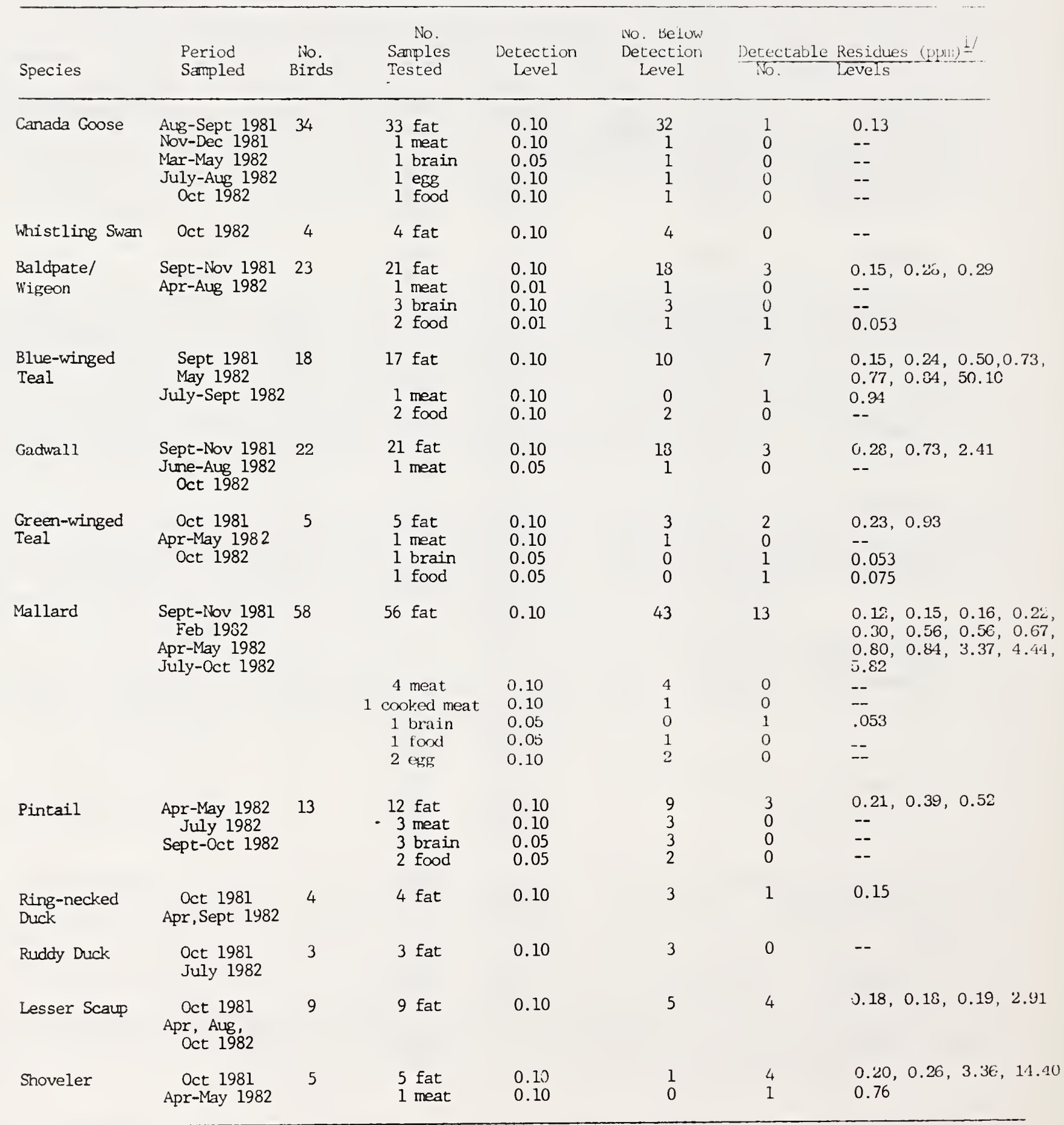

1/ Primarily wet weight basis, but a few may be on a lipid basis. 
PCB residues in fat of adult ducks suggested that sources of PCB's occurred outside, as well as within, the state. Five of 8 adults with the highest levels were taken in the spring (2.9150.10 ppm, April-May 1982); 1 each were also obtained in summer (2.41 ppm, June 1982), fall (4.44 ppm, October 1981), and winter (5.82 ppm, Eebruary 1982). Those ducks could have obtained PCB's on their wintering areas, along spring/fall migration routes, and/or on nesting areas.

Ten of 12 spring-collected ducks with detectable PCB residues in their fat were males. Male ducks tend to follow their mates during spring migration (i.e. males can be hatched and reared in one state/flyway and breed in other states/flyways each of their adult years) and their source of PCB contamination would be difficult to delineate. Female ducks tend to return to their natal areas each year for nesting, so their source of PCB contamination would be more limited but still difficult to identify.

In summer (June-August), all sex-age classes were represented in the 17 duck fat samples having detectable PCB residues, indicating that the source of at least some PCB's was local. Although adults had higher PCB levels in fat (avg. 0.27 ppm; range, $0.15-2.41 \mathrm{ppm}, \mathrm{N}=11$ ) than juveniles (avg. 0.19 ppm; range $0.12-0.20 \mathrm{ppm}, \mathrm{N}=6)$, PCB presence in juveniles was a positive indication of local sources of PCB's. Three of the juveniles (lesser scaup) were taken as flightless young from a pond in Chouteau County. Because ducks positive for PCB's were obtained in 8 different counties in eastern Montana, PCB availiability was apparently widespread.

Fat samples from 10 ducks which contained detectable PCB residues in fall (September-October) indicated that regardless of the source of PCB's, the compound was present in ducks about to migrate south from Montana. Those fat samples were obtained from 4 duck species and from 6 widespread counties in the central Flyway portion of the state. Each sex-age class, except adult females, was represented in the PCB-contaminated samples. None of the detected PCB residues in fall exceeded the 5.0 ppm action level established by the USDA.

One of 2 adult male mallards obtained in winter (February 1982) contained $5.82 \mathrm{ppm}$ PCB in its fat. While numbers of samples from ducks for all seasons were relatively small, the occurrence of PCB's during each season indicates PCB contamination is a year-round occurrence in Montana. Thus, at least 10 species of ducks inhabiting Montana at one time or another each year are exposed to documented or potential hazards imposed by PCB's.

Other Aquatic Birds and Migratory Game Birds. Three species which rely heavily on aquatic vertebrates (eg. fish) for food revealed high levels of PCB's in their fat (Table 35). Four eared grebes and the loon taken in April in Chouteau County exhibited levels in excess of $1.0 \mathrm{ppm}$ PCB. The single white 


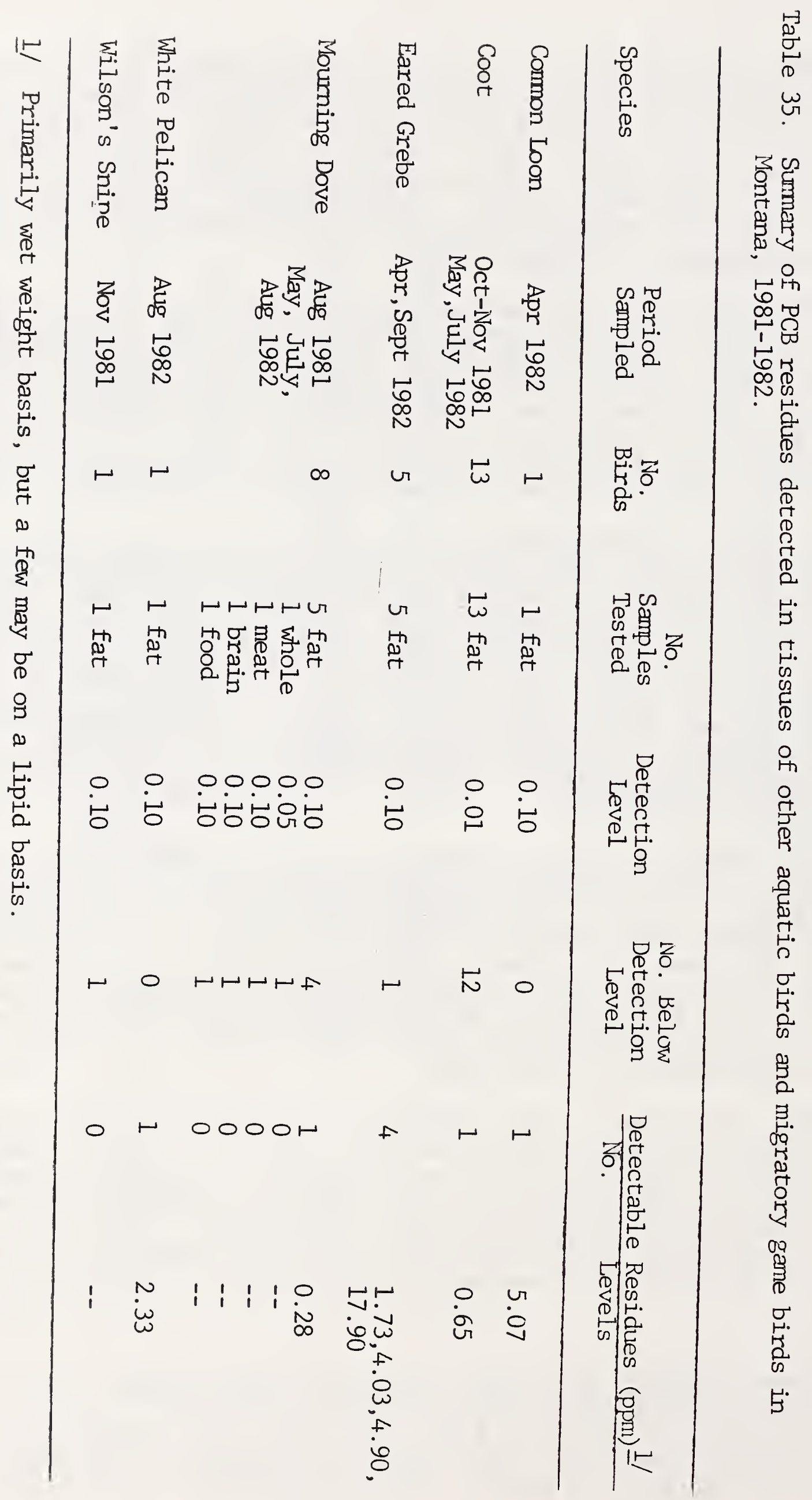


pelican, obtained as a live, but emaciated casualty of a bullet wound, also contained significant PCB's in its fat.

Coot, which are primarily aquatic vegetation feeders, exhibited a low frequency of PCB contamination in their fat. The terrestrial mourning dove was also relatively free of detectable PCB's, although an adult female collected in July from Richland County did have $0.28 \mathrm{ppm}$ in her fat.

Raptors. This group of predatory birds, at the peak of its trophic food pyramid, exhibited the highest frequency of PCB contamination of all wildlife sampled (Table 36); it was second only to waterfowl in maximum levels of PCB's detected. Each raptor species tested migrates to or through, breeds in, and winters (except kestrels) in Montana. Main food items include small mammals, birds and insects. Positive specimens were taken from 5 of 6 Montana counties sampled.

The 2 highest levels of PCB's in fat occurred in a great horned owl (24.8 ppm) and a golden eagle (14.7 ppm) obtained in early winter (Nov.-Dec.). Two juvenile harriers in late summer (Aug.-Sept.) contained detectable PCB residues $(0.67 \mathrm{ppm}$ and 1.36 ppm). The single detectable PCB residue in brain was found in an adult female kestrel in July. Those specimens indicate a probable local source of PCB's.

Long-eared owls taken in April and May containing 1.10 and $2.20 \mathrm{ppm}$ PCB in their fat, suggested some PCB's were brought into Montana from out-of-state sources.

Passerines. Tissue samples from 13 passerine species collected during November 1981-September 1982 were tested for PCB residues. Tissues totaled 83 whole bodies, 44 fat, 42 brain, 1 crop contents/food items, and the contents of 3 eggs. Detectable levels of PCB's were reported from 4 whole body (5\%), 12 fat $(27 \%)$, and 2 brain ( $5 \%$ ) samples (Table 37 ).

Horned larks accounted for the largest number of positive samples, including 2 of 9 fat samples, 2 of 3 whole bodies, and both brain samples which contained detectable PCB's. Composite samples composed of tissues of 2 adult females collected in Fallon County in May 1982 contained $0.42 \mathrm{ppm} \mathrm{PCB}$ in fat and 0.19 $\mathrm{ppm}$ in brains. A second adult female, also taken in Fallon County in May 1982, but over 20 miles from those noted above, had $0.25 \mathrm{ppm}$ PCB in her fat. The other 3 horned lark samples positive for PCB were taken in Musselshell County in June-July 1982 during field studies involving alternative cutworm insecticides. These included whole bodies of an adult male (0.83 ppm) and an adult female (1.68 ppm), and a composite sample of 3 adult female brains $(0.24 \mathrm{ppm})$.

Horned larks are both resident and migratory in Montana. The presence of PCB's in horned larks indicated that local sources of 


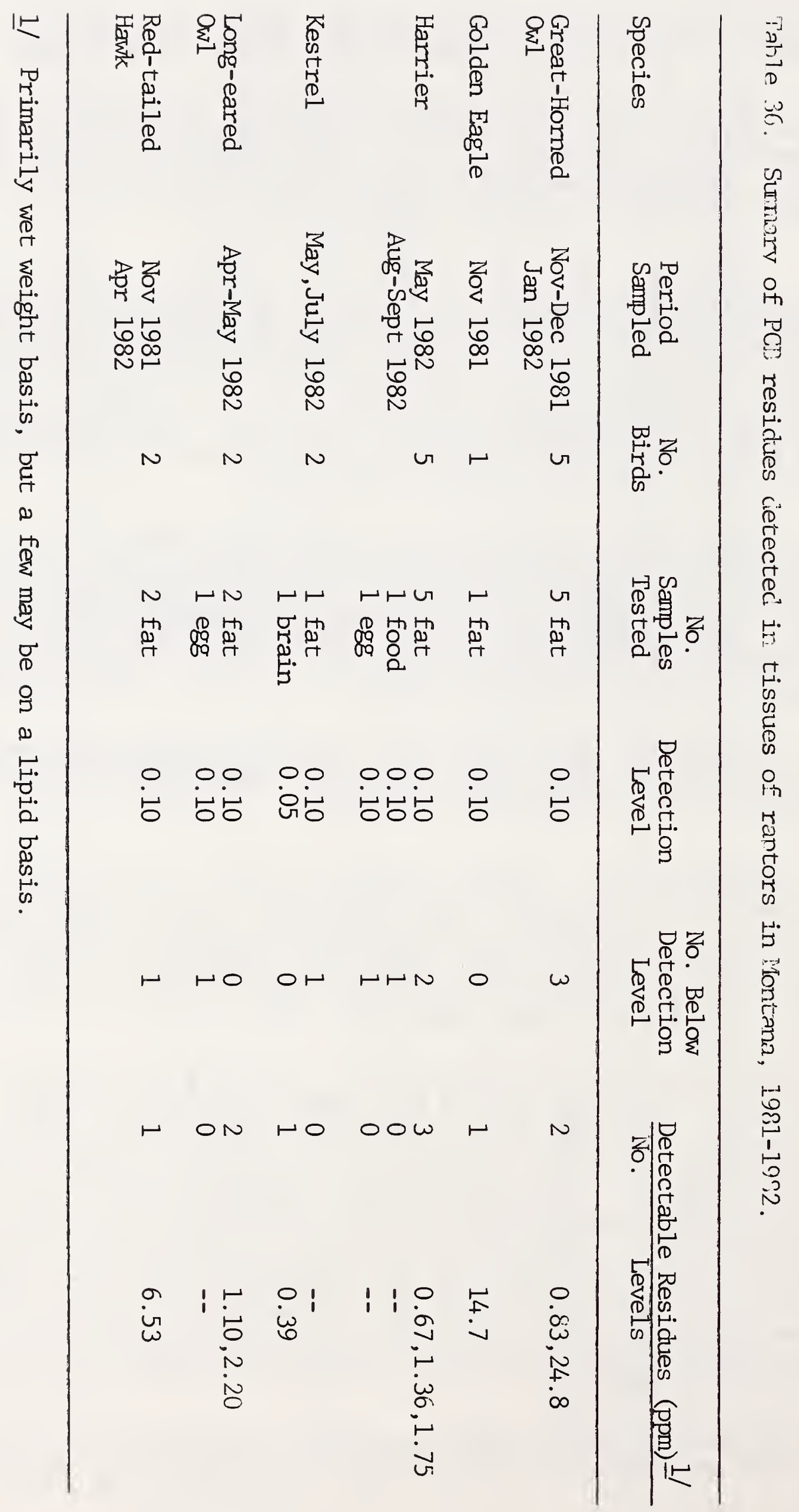


Table 37. Sumary of PCB residues detected in tissues of passerine birds in Pontana, 1081-1982.

\begin{tabular}{|c|c|c|c|c|c|c|c|}
\hline Species & $\begin{array}{l}\text { Period } \\
\text { Sampled }\end{array}$ & $\begin{array}{l}\text { lb. } \\
\text { Birds }\end{array}$ & $\begin{array}{l}\text { No. } \\
\text { Samples } \\
\text { Tested }\end{array}$ & $\begin{array}{l}\text { Detection } \\
\text { Level }\end{array}$ & $\begin{array}{l}\text { No. Below } \\
\text { Detection } \\
\text { Level }\end{array}$ & $\frac{\text { Detectable }}{16}$ & $\frac{\text { Residues (ppro) } 1 /}{\text { Levels }}$ \\
\hline $\begin{array}{l}\text { Chestmut- } \\
\text { collared } \\
\text { Longspur }\end{array}$ & Apr 1982 & 2 & $\begin{array}{l}2 \text { whole } \\
1 \text { brain }\end{array}$ & $\begin{array}{l}0.05 \\
0.10\end{array}$ & - & $\begin{array}{l}0 \\
0\end{array}$ & -- \\
\hline Cliff Swallow & July 1982 & 3 & $\begin{array}{l}3 \text { fat } \\
3 \text { whole } \\
1 \text { brain }\end{array}$ & $\begin{array}{l}0.10 \\
0.05 \\
0.05\end{array}$ & $\begin{array}{l}0 \\
2 \\
1\end{array}$ & $\begin{array}{l}3 \\
1 \\
0\end{array}$ & $\begin{array}{l}0.32,0.36,0.74 \\
0.06 \\
--\end{array}$ \\
\hline Cowbird & May 1982 & 1 & 1 fat & 0.10 & 0 & 1 & 0.56 \\
\hline Horned Lark & $\begin{array}{l}\text { Nov } 1981 \\
\text { Apr-Sept } 1982\end{array}$ & 82 & $\begin{array}{c}27 \text { fat } \\
55 \text { whole } \\
27 \text { brain } \\
3 \text { egg }\end{array}$ & $\begin{array}{l}0.10 \\
0.05 \\
0.10 \\
0.05\end{array}$ & $\begin{array}{r}25 \\
53 \\
25 \\
3\end{array}$ & $\begin{array}{l}2 \\
2 \\
2 \\
0\end{array}$ & $\begin{array}{l}0.25,0.42 \\
0.83,1.68 \\
0.19,0.24 \\
--\end{array}$ \\
\hline Lapland Longspur & e Nov 1981 & 1 & 1 whole & 0.05 & 1 & 0 & -- \\
\hline $\begin{array}{l}\text { Loggerhead } \\
\text { Strike }\end{array}$ & May 1982 & 1 & $\begin{array}{l}1 \text { fat } \\
1 \text { brain }\end{array}$ & $\begin{array}{l}0.10 \\
0.10\end{array}$ & $\begin{array}{l}0 \\
1\end{array}$ & $\begin{array}{l}1 \\
0\end{array}$ & 1.24 \\
\hline $\begin{array}{l}\text { MeCown's } \\
\text { Longspir }\end{array}$ & $\begin{array}{l}\text { Apr } 1982 \\
\text { Sept } 1982\end{array}$ & 7 & $\begin{array}{l}2 \text { fat } \\
6 \text { whole } \\
3 \text { brain }\end{array}$ & $\begin{array}{l}0.10 \\
0.05 \\
0.10\end{array}$ & $\begin{array}{l}2 \\
6 \\
3\end{array}$ & $\begin{array}{l}0 \\
0 \\
0\end{array}$ & $\begin{array}{l}-- \\
-- \\
--\end{array}$ \\
\hline Meadowlark & $\begin{array}{l}\text { Apr-May } 1982 \\
\text { Sept } 1982\end{array}$ & 4 & $\begin{array}{l}4 \text { fat } \\
4 \text { brain }\end{array}$ & $\begin{array}{l}0.10 \\
0.10\end{array}$ & $\begin{array}{l}1 \\
4\end{array}$ & $\begin{array}{l}3 \\
0\end{array}$ & $0.35,0.40,0.67$ \\
\hline $\begin{array}{l}\text { Red-winged } \\
\text { Blackbird }\end{array}$ & May 1982 & 1 & $\begin{array}{l}1 \text { fat } \\
1 \text { brain }\end{array}$ & $\begin{array}{l}0.10 \\
0.10\end{array}$ & $\begin{array}{l}1 \\
1\end{array}$ & $\begin{array}{l}0 \\
0\end{array}$ & -- \\
\hline Show Bunting & Nov 1981 & $2^{\cdots-}$ & $\begin{array}{l}1 \text { fat } \\
2 \text { whole } \\
1 \text { brain } \\
1 \text { food }\end{array}$ & $\begin{array}{l}0.10 \\
0.05 \\
0.10 \\
0.05\end{array}$ & $\begin{array}{l}0 \\
2 \\
1 \\
1\end{array}$ & $\begin{array}{l}1 \\
0 \\
0 \\
0\end{array}$ & $\begin{array}{l}0.66 \\
-- \\
=- \\
--\end{array}$ \\
\hline Vesper Sparrow & $\begin{array}{l}\text { May } 1982 \\
\text { July-Sept } 1982\end{array}$ & 10 & $\begin{array}{r}2 \text { fat } \\
10 \text { whole } \\
2 \text { brain }\end{array}$ & $\begin{array}{l}0.10 \\
0.05 \\
0.10\end{array}$ & $\begin{array}{r}1 \\
10 \\
2\end{array}$ & $\begin{array}{l}1 \\
0 \\
0\end{array}$ & $\begin{array}{l}0.54 \\
-\infty \\
--\end{array}$ \\
\hline $\begin{array}{l}\text { White-crowned } \\
\text { Sparrow }\end{array}$ & May 1982 & 3 & $\begin{array}{l}2 \text { fat } \\
3 \text { whole } \\
1 \text { brain }\end{array}$ & $\begin{array}{l}0.10 \\
0.10 \\
0.10\end{array}$ & $\begin{array}{l}2 \\
3 \\
1\end{array}$ & $\begin{array}{l}0 \\
0 \\
0\end{array}$ & $\begin{array}{l}-- \\
--\end{array}$ \\
\hline $\begin{array}{l}\text { Yellow-rumped } \\
\text { Warblex }\end{array}$ & May 1982 & 1 & 1 whole & 0.10 & 0 & 1 & 0.22 \\
\hline
\end{tabular}

1/ Primarily wet weight basis, but a few may be on a lipid basis. 
those compounds were available. Because their primary foods are seeds, fruits, and insects, detection of PCB in horned lark tissues in spring and summer suggests the source is insects.

Although there was only limited collecting of 12 other passerine species, PCB's were detected in 7 of those. The highest PCB residue detected in passerines was $1.24 \mathrm{ppm}$ in fat of an adult loggerhead shrike taken in May 1982 in Dawson County. This species is migratory and also breeds in Montana, and principal dietary items include small mammals and birds, and large insects. The high level of PCB found in this bird suggested that PCB's were obtained in its wintering area, or while enroute to Montana.

Cliff swallows were subject to notable PCB intake. Each of 3 adult females collected contained detectable PCB's in their fat, while 1 also had it in her whole body. A composite sample consisting of the brains of these 3 birds contained no detectable $P C B$ residues.

PCB residues detected in fat samples of cowbird ( 1 of 1 tested), snow bunting ( 1 of 2), vesper sparrow (1 of 2), and meadowlark ( 3 of 4), and in the single carcass of a yellow-rumped warbler, suggested widespread availability of those compounds to a variety of other passerine species.

\section{Miscellaneous Samples}

One of 2 cutworm samples obtained in June 1982 from the alternative insecticide-wildlife study area in Golden Valley County contained $0.36 \mathrm{ppm} \mathrm{PCB} \mathrm{(} \mathrm{Table} \mathrm{38),} \mathrm{a} \mathrm{significant} \mathrm{finding}$ since the cutworms would require immediate access to the compound for it to appear in their bodies. Either PCB's would have had to have been present as a relatively stable component in the soil, or applied recently to soils and vegetation or onto the cutworms themselves.

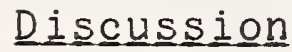

Polychlorinated biphenyls are a group of synthetic chlorinated hydrocarbons with 189 theoretically different chemical arrangements of the chlorine atoms; only 102 arrangements have been identified (Dustman et al. 1971). They are manufactured, primarily by Monsanto Company, as Aroclor 1221, 1232, 1242, 1248, 1254, 1260, 1262, and 1268; the last two digits reflect the chlorine percentage in the compound. Physically, PCB's are thermoplastic, non-drying, remain stable during long heating at $1500^{\circ} \mathrm{C}(302 \mathrm{OF})$, and are electrical non-conductors (Reynolds 1969). Chemically they behave like DDT in that they are poorly soluble in water, readily soluble in fats, concentrate in animal fats, and increase through trophic levels in food chains (Heath et al $1972 a)$. 


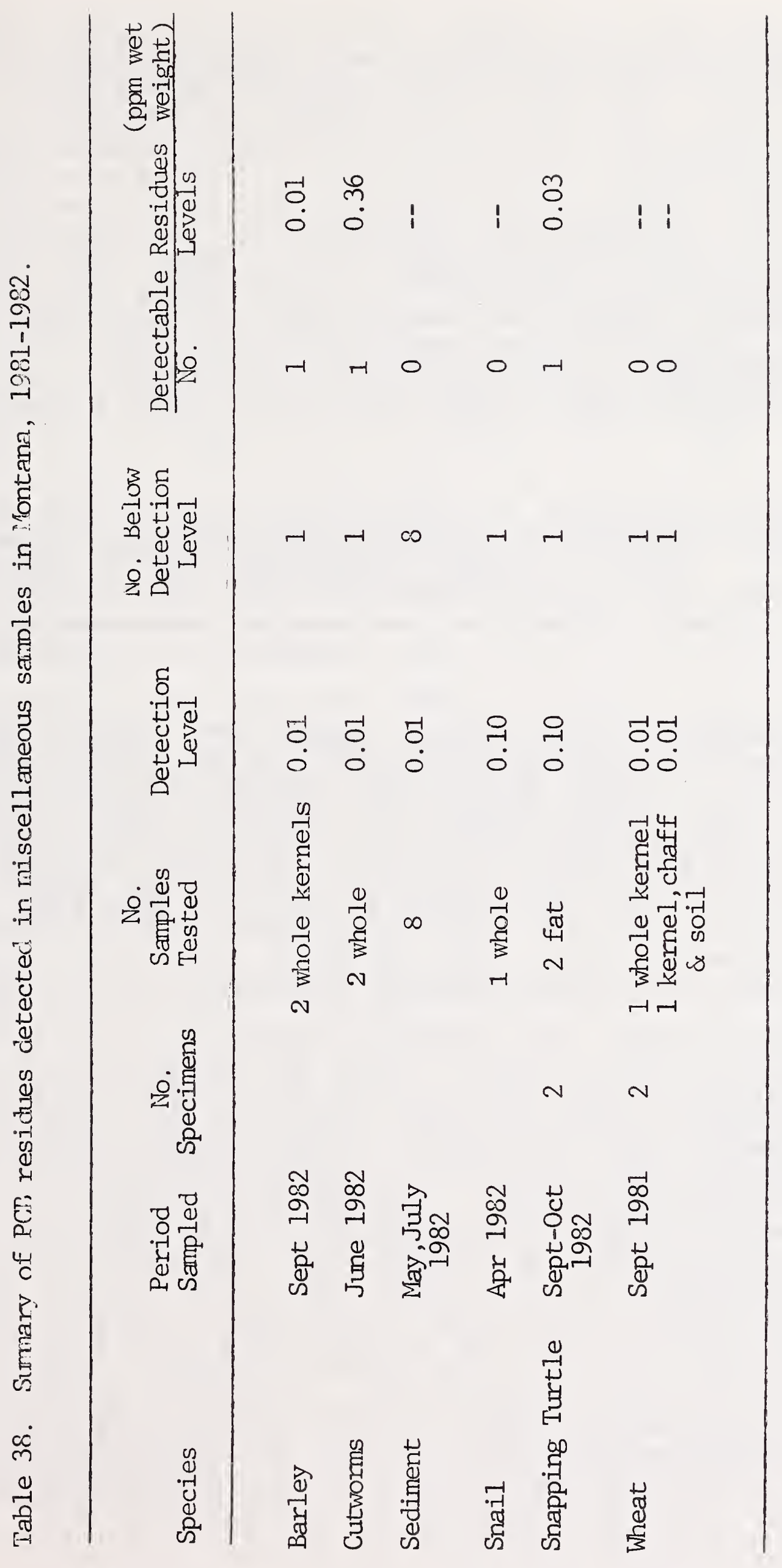


PCB's are sold as liquids, resins, and solids (Reynolds 1969). They have many industrial uses: as plasticizers in electrical insulators and impregnators; as grinding and cutting oils, hydraulic fluids, and high-temperature lubricants; in marine anti-fouling paints; as protective coatings, such as waxes, in cardboard cartons; as sealers in water-proofing compounds and putty; as dust abaters in detergents; as binders in asphaltjc materials; in printing inks; and, as adhesives (Reynolds 1969, Dustman et al. 1971, Heath et al. 1972a). They have been used industrially in large amounts since the 1930's (Heath et al. 1972a). Although general inferences have been made that industrial uses of PCB's have been responsible for global contamination of environments via waste discharges and incineration of products containing PCB's, such uses do not totally explain the presence of PCB's in local rural environments, such as those in Montana.

PCB's are also known for their ability to "trap" and hold other volatile ingredients, including pesticides, thereby increasing their residual activity (Reynolds 1969). Insecticides which have been combined with PCB's for prolonged killing activity include lindane, chlordane, and benzene hexachloride. Such use may be the source of local PCB contamination in Montana.

Relationships to Wildiife. The highest PCB residues detected in Montana were apparently not sufficient to result in acute toxicity levels in upland game birds (Dahlgren and Linder 1971, Heath et al. 1972a, 1972b; Bagley and Cromartie 1973), waterfowl (Heath et al. 1972a, Custer and Heinz 1980), other aquatic birds (Anderson and Hickey 1976), or raptors (McLane and Hughes 1980). Generally, endrin has been shown to be 100 times more toxic, dieldrin 10 times, and DDT only 4 times more toxic than PCB's to pheasants, bobwhite quail, and mallards (Table 39). However, birds have exhibited varying degrees of sensitivity to PCB's.

Breeding mallards were generally unresponsive to different levels of PCB's in their diets. Those fed 150 ppm Aroclor 1242 showed arithmetic increases in numbers of infertile eggs, embryo mortality in eggs 2 weeks old until hatching, and a decrease in the mean number of eggs hatched per clutch; there was no statistically significant difference between the respective means of the controls and experimental birds (Hazletine and Prouty 1980). Adult hens experienced no differences in time required to lay each clutch in this feeding regime, but did have significantly depressed weights after 6, 8, and 12 weeks on the diet. In another mallard study (Custer and Heinz 1980), feeding breeding hens a 25 ppm Aroclor 1254 diet revealed similar results, plus there was no effect on clutch size nor on laying behavior of the hens. The latter study reported an increase in egg fertility. The authors concluded that there was no reproductive impairment by PCB's at that dietary level in wild mallards; carcasses of males at the end of the study contained 64.2 ppm PCB and females had $55.3 \mathrm{ppm}$. 
Table 39. Acute oral toxicities of PCB's and three organochlorine insecticides fed to 2-week old game birds (adapted from Heath et al. 1972b).

$$
\mathrm{LC}_{50}{ }^{1 /} \text { (ppm in diet) }
$$

Chemical Mallard Pheasant Bobwite

$\begin{array}{lccc}\text { PCB2/ } & 1975-3180 & 1090-3150 & 605-3000 \\ \text { DDT } & 1870 & 310 & 610 \\ \text { Dieldrin } & 185 & 56 & 39 \\ \text { Endrin } & 22 & 14 & 14\end{array}$

$1 /$ Expected to produce 50\% mortality in 8 days (5 days on treated diet plus 3 days on untreated diet).

2/ Includes Aroclor 1232, 1242, 1248, 1254, 1260, and 1262.

Mallards fed PCB's have shown increased susceptibility to disease. Friend and Trainer (1970b) reported that 10-day old ducklings fed 25, 50, or $100 \mathrm{ppm} \mathrm{PCB's} \mathrm{in} \mathrm{diets} \mathrm{were} \mathrm{almost} \mathrm{twice}$ as susceptible to duck hepatitis virus (65\%), a virulent waterfowl disease, as control ducklings (no PCB's, $35 \%$ ). Mortality due to the disease was $14 \%$ for the controls compared to $35-44 \%$ for ducklings fed PCB's. PCB-treated ducklings also exhibited disease symptoms 8-16 hours earlier than the controls, i.e. the virus experienced a shorter incubation period.

Terrestrial game birds responded differently than waterfow]. to PCB's; studies with pheasants are illustrative. All 11-week old pheasants died within 6 days after being given a single capsule containing $210 \mathrm{mg}$ Aroclor 1254; they stopped eating after the first day, were inactive and experienced tremors the second day, had additional tremors, and then became comatose before death (Dahlgren et al. 1972a). Levels of PCB in those birds were 320-770 ppm (wet weight) in the brain, 390-3,900 ppm in the liver, and 51-290 ppm in muscle. The authors believed that 300$400 \mathrm{ppm} P C B$ in the brain indicated a lethal level. The same study showed that diets containing $20 \mathrm{mg}$ PCB given every 3.5 days resulted in $100 \%$ mortality within 54 days whereas a simijarly timed feeding of $10 \mathrm{mg}$ caused $100 \%$ mortality in 179 days. Pheas ants dying of PCB poisoning had smaller hearts and very small spleens due to lymphocyte depletion.

Pheasants appear to absorb PCB's rapidly and retain them over extended periods of time (Dahlgren et al. 1971). Hens with 2, 20, or $200 \mathrm{ppm}$ Aroclor 1254 injected into breast muscle absorbed $94 \pm 7 \%$ of that compound within 12 hours, after which PCB levels declined; however, $40.5 \%$ of $\mathrm{PCB}$ remained 28 days after initial injection. It appeared that the higher the PCB dosage, 
the higher the level of PCB retention. That study also showed that laying hens excreted PCB in eggs (average of $4.2 \mathrm{mg}$ per egg) and in their feces (4.0 mg during a 28-day period).

In a later study, Dahlgren et al. (1972b) found that stressed pheasant hens (alternately starved for 2-3 days and then fed for 2 days, after being given $50 \mathrm{mg}$ PCB by capsule at different time intervals) died with about 200 ppm PCB in the brain. Stress related to temporary food shortages and severe weather could occur naturally during severe winters in Montana.

A $50 \mathrm{mg}$ Aroclor 1254 dose (capsule) given each week to pheasant hens during laying significantly reduced egg production (Dahlgren et el 1971). No statistically significant change occurred in hatchability although there was an arithmetic reduction as PCB's accumulated; there was no change in eggshell thickness. Behavior of chicks hatched from those eggs was significantly impaired: $24 \%$ (vs. $8 \%$ for controls) made wrong decisions when confronted with the shallow-deep cliff test, and $38 \%$ (vs. $21 \%$ for controls) made no decision in the allotted time period.

Other biological actions which reflect chronic debilities due to exposure to PCB's include aberrant behavioral patterns and adverse physiologic changes. Peakall and Peakall (1973) reported that embryonic mortality of ring doves (Streptopelia risoria) was greatly increased in eggs incubated by parents which had been given $10 \mathrm{ppm}$ Aroclor 1254 in their diets. Part of that mortality was attributed to inattentiveness of the parents during incubation.

Ring doves fed 1, 10 or 100 ppm Aroclor 1254 exhibited a depletion of dopamine and norepinephrine (Heinz et al. 1980). Dopamine is one of several hormones which help prevent motor dysfunctions by neutralizing acetylcholine released during nerve reactions, like muscle contractions. Norepinephrine helps maintain the steady state of the body (eg. blood pressure, heart rate, insulin release). The 100 ppm PCB diet also resulted in depressed hematocrit.

Aroclor 1254 fed at $100 \mathrm{ppm}$ in the diets of coturnix quail for 12 weeks resulted in significantly increased activity of 5 body enzymes, while blood hematocrit and hemaglobin concentrations decreased significantly (Dieter 1974). Increased liver weights were noted, and irreversible liver danage ultimately occurred when high concentrations of PCB'S, DDE, and mercuric chloride accumulated.

Juvenile herring gulls (Larus argentatus), fed a diet of fish containing about $3 \mathrm{mg} / \mathrm{kg} P C B$, continued to decrease in $P C B^{\prime} \mathrm{s}$ until after fledging; then there was a temporary dynamic equilibrium which was followed by a buildup of fat and PCB's in winter (Anderson and Hickey 1976). Maximum body burdens of PCB's were reached in juvenile and adult birds (adults were fed the 
same diet) when winter fat deposits declined prior to the breeding season. After that decline, PCB's again returned to dynamic equilibrium.

McLane and Hughes (1980) found no detectable effect of a diet containing $3.0 \mathrm{ppm}$ Aroclor 1248 on the reproduction of screech ow ls. However, PCB's were transferred from parents to eggs to hatchlings, and 2 of the downy young died 1-4 days after hatching; their carcasses contained 4.14 and $4.54 \mathrm{ppm} \mathrm{PCB}$. The authors thought the PCB diet given represented a mid-zone in PCB residues in eggs and carcasses when compared with wild birds.

Mammals appear to be more sensitive than birds to PCB's. Studies with guinea pigs and rabbits suggested that single, oral doses ( $4 \mathrm{mg} / \mathrm{kg}$ ) passed unabsorbed through the intestines (Smith 1931, in Savage 1971), whereas 2 oral doses (69 $\mathrm{mg}$ of $42 \%$ chlorine biphenyl) given 1 week apart caused mortality (Miller 1944, in Savage 1971). Rats fed $0.05 \mathrm{~g}$ of $65 \%$ chlorinated biphenyl per animal every other day exhibited a $50 \%$ mortality rate (Bennett et al. 1938, in Savage 1971).

Two of four bats fed diets containing 10 ppm Aroclor 1254 died during a 37-day period; PCB levels in their brains were about $20 \mathrm{ppm}$ (Clark and Prouty 1977). However, PCB levels in fat of the bats had to reach 60-90 pprn before it was measurable in the brajn. PCB levels also tended to be higher in the fat of males than in females. Earlier research had revealed that PCB's were transferred across the placenta (Clark and LaMont 1976), hence pregnancy provided a simultaneous PCB-purging mechanism for females and a source of pre-parturition contamination for progeny. That study also showed that PCB's were passed from mother to offspring during lactation/nursing. Further, PCB's in adult females declined linearly with increasing age, but the decline stopped at 4 ug and then began increasing again.

Mink appear to be significantly more sensitive than the aforementioned mammals to PCB exposure. Fish diets containing 30 ppm PCB killed all adults and $10 \mathrm{ppm}$ killed 5 of 6 adults (Aulerich et al. 1973, in Stendell 1976). Adults on 5 ppm and 10 ppm diets failed to reproduce, while 1 ppm caused reduced reproduction. In a second study (Platanow and Karstad 1973), a diet of beef containing $3.57 \mathrm{ppm}$ PCB killed all breeding mink and a $0.64 \mathrm{ppm}$ diet killed several adults; only 1 of 12 adult females fed the latter diet produced young and her 3 kits died the day after birth.

Based on the above information, only limited interpretation could be made about PCB levels found in deer mice and the blacktailed prairie dog in Montana. None of those individuals apparently contained sufficient PCB's to result in mortality. However, PCB residues in those species clearly indicated that there was á local source, and that mink or other mustelids could obtain potentially hazardous PCB levels from their prey. 
The principal hazard of PCB's to some forms of wild ife in Montana appears to be highly altered physiologic processes rather than acute, oral toxicity. Those changes result from chronic exposure to low or moderate concentrations of PCB in diets and could generate abnormal behavior patterns and increased susceptibility to predation and/or disease.

It is apparent from our test results that PCBis are available in Montana, and that migratory birds are also assimilating $\mathrm{PCB}^{\prime} \mathrm{s}$ on their wintering areas and/or along spring migration routes to Montana. It is equally apparent that Montana PCB sources are available year round. The most likely PCB sources in Montana are in pesticide carriers and in oil products (eg. hydraulic fluids, lubricants, and those used in dust abatement and surfacing of roads). Incineration of materials containing PCB's (eg. newspapers, cardboard boxes, paints, oil products, plastics) in Montana or in the region upwind also could result in aerial transport and subsequent deposition in Montana.

Relationships to Human Health. Problems involving the potential for PCB contamination of human foods are not new to Montana. During fall 1979, a transformer containing PCB cooling fluids ruptured at the Pierce Packing Company in Billings, releasing an estimated 200 gallons of the toxic chemical which eventually contaminated about 1.9 million pounds of meat meal used for animal feed (Montana Department of Agriculture et al. undated). Subsequent testing of meat and egg samples resulted in the destruction of about 449,000 dozen eggs, 290,000 chickens, 149 turkeys, 347 ducks, 5,970 swine, and 714,260 lb of feed and meal. This incident involved 3 state and 2 federal agencies; disposal actions impacted 114 different feed companies and livestock producers, and numerous individuals in 19 states and 2 foreign countries became involved. More than \$97,000 in unbudgeted funds were spent by Montana state agencies during that incident.

While the PCB issue in 1979 apparently did not involve contamination of wildiffe meat to be consumed by people, the current findings do involve that meat, especially from waterfowl. The USDA's action level of $5.0 \mathrm{ppm}$ PCB in domestic meat was exceeded in only 3 of 154 fat samples fron waterfow I normally consumed by hunters. However, 11 of 12 species contained PCB in their fat, indicating most edible waterfowl species were contaminated with PCB, and one fat specimen (from a blue-winged teal) contained 10 times $(50.1 \mathrm{ppm})$ the USDA's action level for PCB. PCB's characteristic affinity for fat, and environmental accumulation and persistence, indicate that there is cause for concern in Montana and elsewhere regarding PCB contamination of wild waterfowl which are eaten by people. 
This is a highly complex group (Stickel et al. 1979b) but the limited scope of this study allows it to be covered in only a cursory fashion. As pointed out earlier, chlordane is a mixture of chlorinated hydrocarbons (primarily alpha - and gammachlordane, plus other related compounds including heptachlor), with the 2 primary constituents oxidizing to form oxychlordane in animals. Chlordane-related compounds identified in our samples included alpha- and gamma-chlordane, oxychlordane, and trans- and cis- (beta) nonachlor. Most residues of those compounds in Montana wildife probably originated from heptachlor use, primarily in Montana but also in other states. Migratory wildife could also obtain these compounds as a result of chlordane use in other states.

Oxychlordane is probably the most important compound because of both its greater frequency of occurrence in tissues sampled, and its toxicity. Residues in brains of birds fed oxychlordane in the diet approached lethality near $5 \mathrm{ppm}$, which is less than lethal $\mathrm{HE}$ levels in brains of birds fed heptachlor-treated diets (Stickel et al.1979b). Lethal brain levels of these 2 compounds in birds on chlordane-treated feed were each only $28 \%$ of those concentrations, suggesting an additive effect of these 2 along with other chlordane compounds (Stickel et al. 1979b). In the remainder of this report the numbers of animals and samples tested per species for each compound are the same as reported for $\mathrm{HE}$ in Tables 27-32.

\section{Resident WildIife}

Oxychlordane was the only chlordane-related compound found in resident wildife, and did not occur in the limited big game samples ( 11 fat and 1 brain) tested.

Among upland birds, only sharp-tailed grouse, and possibly pheasants, were adequately sampled. Oxychlordane occurred in $9 \%$ ( 5 of 56) of the upland bird fat samples tested. However, it was found only in pheasants, where it occurred in $31 \%$ of the birds whose fat was tested. Residues were low, averaging $0.04 \mathrm{ppm}$ (range 0.01-0.09 ppm). Oxychlordane was not found in any of the other limited tissue samples tested (2 meat and 1 each of brain, liver, egg, and food) from upland birds.

Only 1 of $12 \mathrm{small}$ mammal species tested (the deer mouse) was considered to have been adequately sampled for chlorinated hydrocarbons. It was also the only species found to contain oxychlordane, which was present in all tissues tested except the single sample of newborn young. Deer mouse tissues positive for oxychlordane included 1 of 3 embryo, 2 of 42 liver, 3 of 43 brain, and 3 of 77 whole body samples. Residue levels (ppm) included: embryo, 0.20; liver, 0.02 and 4.20; brain, 0.07-0.20; and whole body, 0.354-0.488. 
The high liver residue was in a composite sample taken from 2 adult males trapped at the same location and on the same date, and also contained $30.4 \mathrm{ppm} \mathrm{HE}$. Whether those residues represtnt similar levels in both animals, or higher residues in one than the other is unknown. If the latter is the case, the immediate consequences for individuals in the population would be greater. Also, the significance of liver residues of this magnitude are unknown.

All samples positive for oxychlordane also contained HE, with the exception of one liver sample (0.02 ppm oxychlordane). This was a November-trapped (composite of 2 adult males) sample from an area seeded to winter wheat at least a year earlier. Thus, that residue probably represented the remainder of formerly higher residues which would be expected when treated seeds, or green plants growing from them, were available as food. Finding oxychlordane without $\mathrm{HE}$ also being present is probably related to the fact that oxychlordane is more persistent than HE. Estimated half-lives in birds were 63 and 29 days for oxychlordane and $\mathrm{HE}$, respectively (Stickel et al. 1979b). The often high HE and oxychlordane residues, in the absence of other chlordane-related compounds, points to heptachlor as the source of the HE and oxychlordane in these samples.

\section{Migratory Wild life}

Waterfowl. Waterfowl tissues tested included 189 fat, 9 brain, 13 meat, 1 cooked meat, 9 food, and 3 egg samples. The only tissue which was negative for all 5 chlordane related compounds was cooked meat. Among other tissues tested, oxychlordane occurred in $26 \%$ of fat and $31 \%$ of meat samples, and in 1 of 9 brain, and 2 of 3 egg samples. No oxychlordane was detected in food samples.

Mean oxychlordane residues, and the range in residue levels in fat and meat samples, were $0.10 \mathrm{ppm}(0.01-1.65)$, and $0.017 \mathrm{ppm}$ (0.005-0.04), respectively. Oxychlordane residues in egg samples were 0.01 and $0.25 \mathrm{ppm}$, both were composite samples of $2 \mathrm{mal}$ lard eggs. The single brain sample positive for oxychlordane contained $0.018 \mathrm{ppm}$, and was from an adult male mallard from Chouteau county that also contained the highest oxychlordane levels recorded in fat and meat. Food removed from that bird was negative for oxychlordane, but contained heptachlor and HE, indicating that heptachlor was the source of the oxychlordane (and other chlordane-related compounds) found in that bird. This also indicated a local source of contamination.

Alpha-chlordane residues were found in 4 fat, 5 brain, 3 meat, and 1 egg sample, mostly at low levels. Three fat samples contained 0.51 to $0.82 \mathrm{ppm}$. The higher residue was from the mallard mentioned above, while the other 2 were from a baldpate from Chouteau County and a shoveler taken in Custer county. The baldpate had $14.00 \mathrm{ppm} \mathrm{HE}$, again suggesting heptachlor as the 
source, and probably from the same local source as the mallard. The ratio of HE to oxychlordane (BIus et al. 1983) in the shoveler suggested chlordane as the source of these compounds and it was probably obtained in some other state. These were also the only birds having elevated levels of one or more of the remaining chlordane compounds (gamma-chlordane, and trans- and betanonachlor) in their fat.

Gamma-chlordane was detected in 3 fat, 1 brain, 1 food, and 1 egg sample. With the exception of 2 fat samples $(0.54$ and 0.68 ppm), all contained relatively low levels.

Trans-nonachlor occurred in 9 fat samples ( 3 at $0.22-0.49$ ppm), 2 meat, and 1 egg sample. Beta-nonachlor was detected in waterfowl only in fat ( 3 samples, all $0.20 \mathrm{ppm}$ or less).

Other Aquatic Birds and Migratory Game Birds. Among the 6 species considered here, there were 26 fat and 1 each of whole body, meat, brain, and food samples tested. No individual species was considered to be adequately sampled. Among the various tissues tested, meat and food were negative for chlordane compounds, while only oxychlordane $(0.04 \mathrm{ppm})$ was found in the brain. The single whole body sample tested (a mourning dove) contained oxychlordane, alpha- and gamma-chlordane, and transnonachlor, all at $<0.07 \mathrm{ppm}$. That sample also contained a small amount $(0.046 \mathrm{ppm})$ of compound $E$, a constituent of technical chlordane, indicating exposure to this chemical. However, the occurrence of relatively high HE residues in this sample (2.60 ppm), as well as in the brain (1.62 ppm), fat (53.00 ppm), and food $(0.08 \mathrm{ppm})$ suggested heptachlor was the major, and also local, source of chlordane compounds found in this bird.

Fourteen of the fat samples tested contained oxychlordane, 6 had beta-nonachlor, 2 had trans-nonachlor; alpha- and gammachlordane each occurred in 1 sample. All compounds occurred at $<0.30 \mathrm{ppm}$ with the exception of oxychlordane in an eared grebe $(0.40 \mathrm{ppm})$ and a mourning dove (1.04 ppm), and beta-nonachlor $(0.37 \mathrm{ppm})$ in an eared grebe.

Chlordane compounds in these birds appeared to result largely from heptachlor exposure. Source of exposure was local in at least some cases, such as the food sample, or where flightless young were involved. Other birds could have been exposed locally and/or during migration, or in wintering areas.

Raptors. The single brain sample tested contained $<0.08 \mathrm{ppm}$ of both oxychlordane and alpha-chlordane, while no chlordanerelated compounds were found in food (1) or egg (2) samples.

Fat samples included 15 that were positive for oxychlordane, 10 for trans-nonachlor, 5 for beta-nonachlor, and 1 for alphachlordane. No gamma-chlordane was detected in fat. Residues of all compounds in fat were $<0.30 \mathrm{ppm}$ except for oxychlordane in 4 
samples which ranged from 0.37 to $2.08 \mathrm{ppm}$. The source of chlordane compounds in raptors is less clear than in other wild life groups tested.

Passerines. Thirteen passerine species were tested for chlordane compounds, but only the horned lark was adequately sampled. Samples tested (all species) included 81 whole bcdy, 44 fat, 42 brain, 3 egg, and 1 food. Food and egg samples did not contain detectable levels of any chlordane compounds. Oxychlordane occurred in minor amounts in 2 brain samples $(0.04$ and $0.09 \mathrm{ppm}$ ).

Two chlordane compounds were found in whole body samples of passerines, including oxychlordane in 13 samples and transnonachlor in 1. All but one of the chlordane-related residues in whole body samples were less than $0.30 \mathrm{ppm}$, and the exception (oxychlordane in a horned lark) amounted to only $0.39 \mathrm{ppm}$.

Passerine fat samples tested included 23 that had detectable levels of oxychlordane, 13 that contained trans-nonachlor, 2 that had beta-nonachlor, and 1 each with alpha- and gamma-chlordane. Fat samples with residues exceeding $0.30 \mathrm{ppm}$ included oxychlordane in 2 horned larks, (0.34, and 2.23 ppm) and oxychlordane $(0.61 \mathrm{ppm})$, beta-chlordane $(0.62 \mathrm{ppm})$ and trans-nonachlor (0.32), all in the same white-crowned sparrow sample.

Based on the compounds and residue levels found in individual samples, it appears that most chlordane-related residues found in passerines resulted from heptachlor use. The occurrence of $\mathrm{HE}$ residues in many additional samples that lacked other chlordane-related compounds supports this hypothesis. All passerine birds sampled are migratory to some degree, and could have obtained these residues locally and/or at any point during migration.

\section{Miscellaneouㅗ Samples}

No chlordane-related compounds were detected in any of the 17 miscellaneous samples tested.

\section{Discussion}

Chlordane is less toxic to several species of birds than many other chlorinated hydrocarbon insecticides (Heath et al. 1972b), and has only recently been implicated in direct mortality of wildlife (Blus et al. 1983). The only registered use for chlordane since 1980 has been subterranean application for termite control (BIus et al. 1983). Chlordane-related compounds found in our samples appeared to originate largely fron heptachlor use, suggesting that residues of those compounds should be declining in incidence and magnitude as heptachlor use is phased out. However, since oxychlordane and HE together have 
an additive lethal affect at considerably lower levels than either alone (Stickel et al.1979b), the potential for at least subacute poisoning and sublethal affects on Montana wildlife will remain for some time.

\section{DDT Group}

The major metabolites and/or components of technical DDT, and the only ones detected in our samples, are DDD and DDE. Both are formed by most living organisms (Brooks 1974b). All metabolites of DDT identified in insects are much less acutely toxic than DDT, except that DDD is more toxic to certain lepidopterous and mosquito larvae (Brooks 1974b). DDD has also been used as an insecticide to some extent because of that toxicity. DDE is more prevalent in the environment, including wildlife, than either DDT or DDD.

Due to its universal environmental distribution and slow degradation, few if any wild birds were free of DDE 10 years ago (Stickel 1973). Large scale forest spraying with DDT in Montana ended in 1964. Since the banning of DDT for most uses in the United States at the end of 1972 (see below), frequency and magnitude of DDE residues have declined. However, it is still frequently found in most large samples of wildife species.

\section{Resident Wildiife}

No detectable DDD residues occurred in any resident wildife samples tested. One fat sample from each group of resident wildlife had detectable levels of DDT. These included a whitetailed deer $(0.29 \mathrm{ppm})$ and a pheasant $(0.06 \mathrm{ppm})$ from the same site in Fallon County, plus a jackrabbit (0.09 ppm) from Musselshell County.

DDE residues were found in 3 of 11 big game fat samples tested. The highest level $(0.19 \mathrm{ppm})$ occurred in the whitetailed deer that also contained DDT. A mule deer and a pronghorn, taken at separate sites in Richland County, each had 0.01 ppm DDE in their fat. No DDE was found in the only big game brain tested.

Upland bird samples positive for DDE included 17 of 56 fat, and the only egg sample (from a pheasant) tested. DDE was found in fat of 3 Hungarian partridge, 3 pheasants, and 11 sharptailed grouse; the maximum level recorded was 0.12 ppm in the pheasant that also contained DDT in its fat. All other upland bird tissues lacked DDE residues (2 meat, and 1 each of brain, liver, and fat). Birds positive for DDE represented a minimum of 7 sites in 5 counties.

Small mammal species that had at least one tissue sample positive for DDE included the deer. mouse, harvest mouse, meadow vole, prairie dog, 13-lined ground squirrel, cottontail rabbit, 
and jackrabbit. The number of tissue samples positive for DDE were: 23 of 97 whole body; 19 of 67 brain; 19 of 64 liver; and 6 of 18 fat samples. Three additional tissues tested ( 2 food, 3 embryo, and 1 newborn) had no DDE present.

DDE residue levels in positive small mammal samples were quite low. Average residues in positive tissues were: whole body, 0.014 (range, 0.005-0.037 ppm); brain, 0.065 (0.006-0.33 $\mathrm{ppm})$; Iiver, $0.020(0.005-0.120 \mathrm{ppm})$; and fat, $0.03(0.009-0.06$ ppm). Positive DDE samples were obtained at all sites at which small mammals were collected.

Five of 12 small mammal species tested were negative for DDE. Species, and number of tissue samples lacking DDE included: house mouse, 3 whole body, 1 brain, and 1 liver; pocket mouse, 1 whole body; porcupine, 1 fat; prairie vole, 3 whole body, 1 brain, and 1 liver; and Richardson's ground squirrel, 3 each of brain, liver, and fat, and 1 food sample.

\section{Migratory Wild life}

Waterfowl. Residues of DDT occurred in waterfowl samples as follows: fat, 24 of 189; brain, 2 of 9; meat, 2 of 13; and egg, 1 of 3. No DDT was detected in 9 food or 1 cooked meat sample tested from waterfowl. Residue levels of DDT in most tissues were low, but 3 fat samples from birds collected in April 1982 contained $3.20,6.01$, and $8.27 \mathrm{ppm}$. The highest level was recorded from a pintail taken in Chouteau County; the others were both mallards, one taken at the same site as the pintail, and the second collected in Dawson County.

DDD was detected in 8 fat, 3 meat, and one brain sample from waterfowl tested. All other tissues were negative for this compound. The maximum level found in any tissue (fat) was 0.41 $\mathrm{ppm}$.

Eighty-five percent of all waterfowl samples, including every type of tissue tested, contained detectable levels of DDE. These included 172 fat, 9 meat, 5 brain, 3 food, 3 egg, and 1 cooked meat sample. One egg ( $1.55 \mathrm{ppm})$ and 24 fat samples contained over 1 ppm of DDE. The number of fat samples that exceeded 1 ppm, and maximum levels found, by species, were: 5 blue-winged teal (6.37 ppm); 2 baldpates (2.59 ppm); 1 gadwall $(2.41 \mathrm{ppm}) ; 2$ green-winged teal (23.20 ppm); 5 mallards ( 23.60 ppm); 3 pintails (9.48 ppm); 1 ring-necked duck (4.46 ppm); 2 ruddy ducks (3.51 ppm); 1 scaup (3.91 ppm); and 2 shovelers $(13.00 \mathrm{ppm})$.

Most elevated residue levels of this group of compounds were found in spring and early summer samples. This, and the relatively low levels of DDT and its metabolites in resident wildlife suggested that those compounds were obtained largely outside of Montana. 
Other Aquatic Birds and Migratory Game Birds. Residues of DDT and DDD were found only in fat samples of these birds. DDT occurred in 4 fat samples, including 1 each of common loon, eared grebe, mourning dove, and white pelican, with a maximum of 0.14 ppm in the loon. The pelican fat sample was the only one found to contain DDD (1.00 ppm).

Detectable DDE residues occurred in the mourning dove whole body sample $(0.009 \mathrm{ppm})$, and in all fat samples tested. The remaining samples ( 1 each of meat, brain, and food) were negative for this compound. The average DDE residue in the 26 fat samples was $2.43 \mathrm{ppm}$, and 8 contained residues that exceeded $1 \mathrm{ppm}$. These included 2 coots $(1.06$ and $1.77 \mathrm{ppm}), 4$ eared grebes (4.00$14.00 \mathrm{ppm}), 1$ white pelican $(11.00 \mathrm{ppm})$, and 1 common loon ( 11.50 $\mathrm{ppm})$.

Raptors. Residues of DDT occurred in 5 fat samples, including 3 from great horned owls and 1 each from red-tailed hawk and kestrel. The maximum level recorded was $0.29 \mathrm{ppm}$ in a kestrel taken in late April 1982 in Dawson County. DDD occurred in only 1 fat sample, $0.17 \mathrm{ppm}$ being found in a red-tailed hawk also taken in late April 1982 in Dawson County. Both undoubtedly obtained those residues prior to arrival in Montana. Remaining raptor tissues contained no detectable residues of either DDT or DDD .

Residues of DDE occurred in every raptor sample tested ( 16 fat, 2 egg, 1 food, and 1 brain). Maximum DDE levels found in fat by species included: long-eared owl, $1.15 \mathrm{ppm}$; red-tailed hawk, 1.49 ppm; kestrel, 6.33 ppm; great horned owl, 15.10 ppm; golden eagle, $24.30 \mathrm{ppm}$; and harrier, $33.70 \mathrm{ppm}$.

Passerines. The only passerine tissue tested that did not contain residues of the DDT complex was a food sample (i.e. crop contents) from 2 adult male snow buntings. Three horned lark egg samples were negative for DDT and DDD, but all contained low levels of DDE (0.030-0.042 ppm).

DDT occurred in only 3 passerine whole body samples. All were horned larks, and the maximum level found was 0.10 ppm. Four brain samples contained DDT at 0.03 ppm or less, including 3 horned larks and 1 vesper sparrow. DDT also occurred in 2 of 44 fat samples, including a cowbird $(0.28 \mathrm{ppm})$ and a white-crowned sparrow $(0.71 \mathrm{ppm})$. Both were taken in early May 1982, in the same general vicinity in Dawson County. As recently arrived migrants, they undoubtedly obtained most, if not all, of their DDT outside of Montana.

DDD occurred in only 2 fat samples (the cowbird and whitecrowned sparrow noted above), and 1 brain sample (the vesper sparrow that also had DDT in its brain). The maximum DDD level found $(0.35 \mathrm{ppm})$ occurred in fat of the white-crowned sparrow. 
Among other passerine tissues sampled, DDE occurred in 63 of 81 whole body, 22 of 42 brain, and 42 of 44 fat samples tested. Highest DDE levels in whole body samples included 0.66 ppm in a yellow-rumped warbler, $0.77 \mathrm{ppm}$ in a cliff swallow, and $2.45 \mathrm{ppm}$ in a white-crowned sparrow.

Brains of 8 species (of 10 tested) had detectable DDE residues. Only the snow bunting and red-winged blackbird (1 sample each) contained no DDE in their brains. The maximum DDE brain level recorded $(0.26 \mathrm{ppm})$ was in a horned lark.

Passerine fat samples positive for DDE had an average of $1.16 \mathrm{ppm}$ (range, $0.02-12.00 \mathrm{ppm}$ ). Nine exceeded $1 \mathrm{ppm}$, including: 1 cowbird, 3.27 ppm; 1 loggerhead shrike, 6.80 ppm; 2 meadowlarks, 1.22 and 2.05 ppm; 2 white-crowned sparrows, 3.69 and $12.00 \mathrm{ppm}$; and 3 cliff swallows, 3.13-7.22 ppm. All of the cowbird, shrike, white-crowned sparrow, and cliff swallow, and half of the meadowlark fat samples tested contained over 1 ppm of DDE. None of the horned lark fat samples positive for DDE (26 of 27 tested) had more than $0.60 \mathrm{ppm}$. The reason for this difference between species is probably related to the degree to which locally breeding birds make long distance migrations to areas in which DDT may still be used.

\section{Miscellaneous Samples}

Only 2 samples in this group contained residues of the DDT complex. No DDT or DDD were detected, while DDE occurred in 1 sediment $(0.014 \mathrm{ppm})$, and 1 snapping turtle fat $(0.005 \mathrm{ppm})$ sample.

\section{Discussion}

DDT was the first and most widely used organochlorine insecticide. Because the scientific literature concerning the relationships between the DDT group and wildlife is so extensive, we are providing only an overview of those relationships as they might apply in Montana.

Although direct mortality of wildlife following spraying of DDT for forest insect control was documented as early as 1945 (Hotchkiss and Pough 1946), and insect resistance to DDT was first noted in 1946 (Brooks 1974b), production and use of DDT mushroomed following World War II. The United States alone produced over 145 million pounds of DDT in 1958, and global production was estimated at 250 million pounds annually (Rudd 1964:61).

Bioaccumulation of chlorinated hydrocarbons, whereby relatively minute amounts applied to an ecosystem are accumulated at ever increasing amounts at each upward step in a food chain, was first demonstrated by Hunt and Bischoff (1960). They reported that DDD, applied for gnat control at a rate that 
resulted in $0.02 \mathrm{ppm}$ in water, resulted in chronic DDD poisoning of western grebes, which died with up to 1,600 ppm of DDD in their fat. Among the potential prey of grebes, it was found that smaller fish accumulated less DDD than larger specimens of the same species, and that plankton feeders accumulated less than carnivorous species of the same size.

Although direct poisoning occurs at high dosages, bioaccumulation is the underlying factor leading to most problems that wildlife ultimately experience with DDT and other chlorinated hydrocarbon insecticides and/or their metabolites.

The discovery that DDE caused thinning of eggshells of many species of birds revealed one of the more serious affects of DDT and its metabolites on wildlife. DDD has not been implicated in this phenomenon, while DDT produces thinning only after lengthy exposure, after which DDE is probably involved (Stickel 1973). Further, DDE is more persistent in birds than DDT or DDD. The half life of DDE is 250 days in the pigeon (Columba livia), compared to 28 and 24 days for DDT and DDD, respectively (Stickel 1973, Brooks 1974b). That persistence accounts for DDE being present in a high percentage of the recent Montana wildlife samples tested, while DDT and DDD are encountered much less frequently.

In retrospect, the first evidence of eggshell thinning was an increased incidence of broken or missing eggs among British peregrine falcons during 1949-1956. It was subsequently demonstrated that a significant decrease in eggshell weight of the peregrine in Great Britain began in 1947 or 1948; the same phenomenon was also reported for North American peregrines and later for many other species (cf. Peakall 1976). In the early 1960's pesticides were hypothesized to be the cause of this problem since it did not manifest itself until after chlorinated hydrocarbon insecticides were widely used (see Hickey 1969). Subsequent experimental laboratory studies established that DDE caused substantial shell thinning among ducks, owls, and hawks (Stickel 1973). Conversely, chickens are highly resistant to this affect (Cecil et al. 1972).

Statistical studies of field collected eggs, comparing shell thickness with residues in their contents, have supported the implication of DDE as the agent responsible for eggshell thinning (Stickel 1973). Those studies also found that flesh- and fisheating birds were the most affected, with susceptibility to shell thinning varying greatly among the various groups of birds. Peakall (1976) reported that the most sensitive of the bird orders studied were the Pelecaniformes (pelicans, cormorants), Ciconiformes (herons, storks), Falconiformes (hawks, falcons, eagles, osprey), and Strigiformes (owls). Least sensitive orders included Galliformes (grouse, pheasant, turkey, chicken) and Passeriformes ("song birds" and their relatives). Differences in sensitivity to eggshell thinning among these groups of birds appear to be physiologically based (Stickel 1973). 
Severe shell thinning has been correlated with reproductive failure and population declines (including local and regional extinctions) in some bird species, notably among peregrine falcons and brown pelicans (Peakall 1976, Blus 1982). Lowered productivity of brown pelicans (Blus 1982) was primarily due to eggshell deficiencies, embryotoxicity, and mortality or aberrant behavior of recently hatched young. DDE has the potential of inducing all of those effects, whereas most other organochlorines usually act through the last two (Blus 1982). He also further reported that $3 \mathrm{ppm}$ (fresh wet weight) DDE in brown pelican eggs was associated with substantially impaired reproductive success, while 4 ppm resulted in total reproductive failure. Peregrine eggs fail to hatch at approximately 15-20 ppm (wet weight) DDE (Peakall et al. 1975), while the minimum effect levels for prairie falcons and merlins were approximately 2 and 6 ppm, respectively (Fyfe et al. 1976a). In the latter study DDE at approximately $12.5 \mathrm{ppm}$ (wet weight) caused reproductive failure in prairie falcons.

Accidental breakage during the course of normal incubation appears to be the major mechanism through which thin-shelled eggs are lost from nests, although aberrant behavior of the adult (Hickey 1969, Peakall 1976) may also be involved. Minor thinning of eggshells occurs naturally as developing embryos extract material from the shell (Vanderstoep and Richards 1971, Kreitzer 1972). This might cause enough additional thinning to result in breakage of some eggs late in incubation. An additional source of mortality caused by eggshell deficiencies was observed by Nelson (1976). He reported that apparently thin-shelled eggs were further weakened when pipping began, resulting in the shell fracturing and flaking off. The intact shell membrane then dried and toughened, trapping the emerging chick.

It has also been reported that increasing DDE contamination significantly decreased nest defense behavior by wild merlins (Fyfe et al. 1976a).

Based largely on evidence that DDE-caused eggshell thinning was responsible for population declines in many birds, DDT use in the United States was banned after 31 December 1972 (Sherman 1977). Use of DDT was severely restricted in Canada in 1969 (Newton 1976).

A number of exemptions for "emergency" use of DDT have been granted since the use of DDT was banned in the United States. Some 426,000 acres of forest in Idaho, Oregon, and Washington were sprayed in 1974 for control of the tussock moth; 112,000 acres were sprayed to control pea leaf weevil in the dry pea crop in Idaho and Washington during 1973 and 1974; 4,000 pounds of DDT were dusted into rodent holes in Colorado in 1976 to destroy fleas that might transmit plague; and other lesser uses have occurred (Sherman 1977).

Despite the relatively minor legal use of DDT in the United States in recent years, DDT is still used in other countries. 
Although firm figures are not available, indications are that global use of DDT is not declining, but merely shifting southward (Peakall 1976). During 1972-1974 an average of over 55 million pounds of DDT ( $100 \%$ basis) was exported from the United States annually (Sherman 1977). The large foreign use, plus any illegal use in the United States, is probably the major source of the residues of DDT and its metabolites found in migratory wildife in Montana. However, the presence of DDT in some Montana resident wild ife as much as 10 years after it was banned indicates that some DDT has been locally available in recent years.

While some populations of birds have shown improved reproductive success following reduced use of DDT, some highly contaminated populations remain. For example, arctic breeding North American peregrines which winter in Central and South America were rapidly declining in 1975 (Fyfe et al. 1976b), with some suggesting they might be passing into extinction in the wild (Peakall 1976). Birds poisoned by DDT and/or its metabolites were still being found in the United states at least 4 years after the ban went into effect (Ohlendorf et al. 1979).

Results of residue tests conducted on potential peregrine prey species in Montana further show that, despite being banned in the U.S., we cannot assume that DDT or its metabolites are not present in migratory wildlife. Whole body samples of every individual of 3 species tested in 1980 ( 8 Brewer's blackbirds, 11 killdeer, and 11 tree swallows) contained DDE. The average (and range in) residue levels by species and area of collection were: Brewer's blackbirds from Carbon and Stillwater counties, 5.50 ppm (0.16-32.86 ppm); killdeer from Toole and Liberty counties, 8.30 ppm (0.43-19.56 ppm); and tree swallows from Gallatin and Park counties, $35.60 \mathrm{ppm}$ (5.70-101.72 ppm) (DeWeese, FWS, unpublished data). These residues are more ominous since they occurred in whole body rather than fat samples, and are expressed on a wet weight, and not a lipid weight, basis. Undoubtedly any raptors feeding heavily on birds contaminated at. the level of the tree swallows would experience reproductive problems.

Dieldrin

Dieldrin is highly toxic to wildlife, ranking only behind endrin, and in most cases aldrin, in toxicity among organochlorine insecticides tested (Heath et al. 1972b). Although dieldrin is used as an insecticide, much of the dieldrin residues found in wildlife results from the use of aldrin, which rapidly converts to dieldrin (Stickel 1973).

\section{Resident Wildlife}

Dieldrin was not detected in any of the big game samples ( 11 fat and 1 brain) tested. Upland game bird samples included 12 of 56 fat, 1 of 2 meat, and 1 of 1 brain sample that contained detectable dieldrin; no dieldrin was found in single samples of 
egg, food, and liver tested. All positive samples contained only small amounts of dieldrin, with a maximum concentration of 0.05 ppm. Positive samples were obtained from a minimum of 8 locations in 5 counties.

Among small mammals, dieldrin occurred in brain ( 5 of 67 ), liver (10 of 64), and fat ( 2 of 18) samples, but was not found in whole body (101), embryo (3), newborn (1), or food (2) samples. The maximum dieldrin level found in positive samples was $0.10 \mathrm{ppm}$ in a liver. Positive small mammal samples were obtained at a majority of the collection sites.

\section{Migratory Wild life}

Dieldrin residues occurred with greater frequency, and at higher maximum levels, in migratory wildlife collected in Montana than in resident species.

The single cooked meat sample was the only waterfowl tissue tested which contained nodieldrin. With the exception of fat, waterfowl tissues contained low concentrations of dieldrin $(0.07$ ppm or less). These included 5 of 9 brain, 6 of 13 meat, 2 of 9 food, and 2 of $3 \mathrm{egg}$ samples. Waterfowl fat samples included 95 (of 190 tested) which contained detectable dieldrin residues. Only 2 of these exceeded the USDA action level of $0.3 \mathrm{ppm}$, a mallard taken in February 1982 in Chouteau County (0.53 ppm), and a shoveler taken in late April 1982 in Park County (0.31 ppm).

Dieldrin occurred in 18 of 26 fat samples tested from other aquatic birds and migratory game birds. It was not detected in single samples of meat, whole body, brain, or food tested. Maximum dieldrin residues in fat $(0.26 \mathrm{ppm})$ occurred in an eared grebe and a white pelican. Two other grebes and a common loon had dieldrin levels of 0.20 ppm or more.

Eleven of 16 fat samples from raptors had detectable dieldrin, while egg (2), brain (1), and food (1) samples contained none. Maximum residues in 4 fat samples by species were: golden eagle, $0.88 \mathrm{ppm}$; great horned owl, 0.77 ppm; harrier, 1.17 ppm; and red-tailed hawk, $2.08 \mathrm{ppm}$.

Positive dieldrin samples from passerines included 8 of 81 whole body, 4 of 42 brain, and 25 of 44 fat samples tested. Highest levels occurred in fat, with a maximum concentration of $0.18 \mathrm{ppm}$ in a horned lark. Dieldrin was not detected in passerine food (1) or egg (3) samples.

\section{Miscellaneous_Samples} samples.

Dieldrin was not detected in any of the miscellaneous 


\section{Discussion}

Dieldrin has all of the negative characteristics of other organochlorine insecticides, including high toxicity, persistence, and affinity for fatty tissues. With the exception of eggshell thinning, most of the deleterious effects of other organochlorine insecticides also apply to dieldrin.

Numerous cases of dieldrin poisoning of wildife, plus other undesirable features, led to the banning of aldrin and dieldrin use in the United States effective 1 October 1974, although the sale and use of existing stocks remained legal (Clark et al. 1978). Documented cases of dieldrin poisoning of wildlife include deaths of at least 3 endangered species: the bald eagle (Prouty et al. 1977, Kaiser et al. 1980), peregrine falcon (Reichel et al. 1974), and gray bat (Clark et al. 1978, 1980). Aldrin was the source of the dieldrin contamination in at least the latter species.

Levels of dieldrin contamination found in Montana wildlife were below those considered hazardous. All of the elevated dieldrin residues occurred in migratory species, notably raptors. Those findings suggested that dieldrin residues in our samples were obtained, for the most part, outside of Montana, and that banning the use of aldrin and dieldrin in the U. S. has probably resulted in reduced losses of wildlife in recent years. Presence of dieldrin residues above the FDA action level nearly 8 years after its use was banned further demonstrates that residues of such highly persistent chemicals will remain for years after they are no longer used.

\section{Hexachlorobenzene}

Hexachlorobenzene (HCB) is used as a fungicide, and is an environmental contaminant (Yang et al. 1978). According to the MDA, HCB occurs as a component of at least 2 fungicides used as preplanting seed treatments in Montana.

\section{Resident Wildlife}

Residues of HCB were detected only in fat samples of big game (2 of 11) and upland game birds (10 of 56) tested. All other tissues of these groups were negative for this compound. The maximum HCB residue found in big game and upland birds was $0.02 \mathrm{ppm}$.

Among small mammals tested, HCB occurred in the following tissue samples: whole body, 4 of 97 ; brain, 2 of 67 ; liver, 4 of 64; and fat, 2 of 18. Maximum residues in small mammals occur. red in brain samples of a harvest mouse (0.11 ppm) and a deer mouse $(0.16 \mathrm{ppm})$. Food (2), embryo (3), and newborn (1) small mammal samples were negative for HCB. 
Overall, HCB residues were detected in resident wild ife representing at least 8 separate sites in 5 counties.

\section{Migratory Wildlife}

Positive waterfowl tissues included 44 of 189 fat, 3 of 9 brain, and 2 of 3 meat samples tested. Most residues were quite low, with maximums (all in fat) of 0.18 pprin in mallard, and 0.40 and $0.88 \mathrm{ppm}$ in 2 green-winged teal. The whistling swan and ring-necked duck were the only species which contained no HCB in their fat ( 4 samples each). Food (9), egg (3), and cooked meat (1) samples from waterfowl were negative for HCB.

Residues of HCB were detected in other aquatic birds and migratory game birds in 1 of 1 whole body and 11 of 26 fat samples tested, with highest levels $(0.20 \mathrm{ppm})$ occurring in fat. Although HCB was detected in fat of every species sampled, eared grebes appeared to be more heavily contaminated than the others. Each of 5 individual eared grebes tested had HCB residues, and 4 of these had the highest levels $(0.10-0.20 \mathrm{ppm})$ found in fat from this group. Single samples of brain, meat, and food of this group were negative for $\mathrm{HCB}$.

Although raptor collections included only a few individuals of a few species, every species tested contained detectable HCB in at least 1 tissue. A single food sample was the only raptor tissue tested which contained no HCB residues. HCB occurred in the only brain, 1 of $2 \mathrm{egg}$, and 12 of 16 fat samples from raptors. Concentrations in brain $(0.044 \mathrm{ppm})$ and egg $(0.02 \mathrm{ppm})$ were quite low, as were most residues in fat. Elevated HCB residues in raptor fat included: harrier, 0.75 ppm; and great horned owl, 0.26 and $0.92 \mathrm{ppm}$.

All passerine tissues tested, except a single food sample, contained HCB residues. These included: whole body, 4 of 81 ; brain, 2 of 42; fat, 20 of 44; and egg, 2 of 3 . HCB residues were generally low, with only 2 samples having elevated levels. These were a whole body $(1.03 \mathrm{ppm})$, and a fat sample (3.95 ppm), which both involved the same juvenile male vesper sparrow. There was not enough fat on this bird to constitute a sample by itself, so it was combined with fat from another bird (an adult male having no detectable HCB in its whole body) taken at the same time and place. Most, if not all, of the HCB detected was probably attributable to the 1 bird. Since this was a juvenile bird taken in mid-August, it undoubtedly obtained its HCB within Montana. However, grain fields adjacent to where this bird was collect.ed were unharvested at that time, and there was no obvious source of treated seed available in the general vicinity.

\section{Miscellaneous Samples}

No HCB was detected in any of the miscellaneous samples. 


\section{Discussion}

Hansen et al. (1978) cited studies with chickens showing that although HCB had a low acute toxicity, prolonged exposure resulted in a variety of ill effects; concentrations of up to 100 $\mathrm{ppm}$ in feed resulted in marked residue accumulation but produced no notable ill effects. Among mammals, HCB was one of the least acutely and subacutely toxic of several pesticides tested on voles, with laboratory rats and mice being somewhat more sensitive (Cholakis et al. 1980). Offspring of adult mink fed 5 ppm HCB experienced poor survival (Rush et al. 1983). Although longterm storage in fat, and slow elimination from animals characterize HCB, the limited information found regarding its potential toxicity to wildlife indicated that residues in our samples posed little or no hazard to Montana wildlife.

Lindane and Benzene Hexachloride

Lindane (the common name of the gamma isomer of benzene hexachloride) is unique among the 3 main structural groups of organochlorine insecticides since it is the only highly insecticidal representative of its group (Brooks 1974a). Because of its relatively high volatility and fumigant action, lindane is well suited as a soil insecticide, and is widely used as a seed treatment. In Montana lindane is used mainly as a preplanting seed treatment on cereal grains.

Of the several other isomers of benzene hexachloride (BHC) only alpha-BHC was found with some frequency in our samples, while the beta isomer occurred only once. Alpha-BHC will simply be called BHC in this evaluation.

\section{Resident WildIife}

Lindane residues occurred in 2, and BHC residues in 3, fat samples from big game animals. Maximum residues in fat were 0.02 ppm for lindane and $0.05 \mathrm{ppm}$ for BHC. The single brain tested was negative for both compounds.

Upland bird tissues positive for lindane included 9 of 56 fat and the only egg sample tested. The maximum lindane concentration found in upland birds was 0.02 ppm in fat of 2 sharptailed grouse. Lindane was not detected in meat (2), brain (1), food (1), or liver (1) samples from upland birds.

Detectable BHC residues in upland birds were found in 18 fat, 1 of 2 meat, and the only brain sample tested. Maximum BHC levels occurred in a sharp-tailed grouse fat sample (0.15 ppm). Tests of single samples of egg, food, and brain were negative for $\mathrm{BHC}$.

Lindane was found in 2 samples each of whole body, brain, and fat from small mammals. Maximum residues occurred in a deer 
mouse brain $(0.11 \mathrm{ppm})$. No lindane was detected in liver, food, embryo, or newborn samples.

BHC was more widespread in small mammals than lindane, being found in 1 of 97 whole body, 11 of 67 brain, 7 of 64 liver, and 4 of 18 fat samples. The highest BHC concentration (0.07 ppm) was found in fat of a black-tailed prairie dog. Food (2), embryo (3), and newborn (1) samples contained no BHC.

\section{Migratory Wildi ife}

Seven fat and 2 egg samples were the only waterfowl tissues which had detectable lindane residues; the maximum lindane residue was 0.04 in the fat of a baldpate. No lindane was found in brain, meat, cooked meat, or food.

Residues of BHC occurred in 1 brain and 25 fat samples from waterfowl, while all meat, cooked meat, food, and egg samples were negative for this compound. No BHC residues in waterfowl exceeded $0.06 \mathrm{ppm}$.

Lindane was not detected in any of the other aquatic bird and migratory game bird samples, while BHC occurred in 5 fat samples, with a maximum of $0.20 \mathrm{ppm}$ found in a white pelican.

Detectable lindane occurred in 2 of 16 raptor fat $(0.03$ and $0.09 \mathrm{ppm})$, and 1 of $2 \mathrm{egg}(0.02 \mathrm{ppm})$ samples. Single food and brain samples were negative for lindane.

Nine raptor fat samples were positive for BHC, with none detected in any other raptor tissue. With one exception $(0.32$ ppm in a long-eared owl), all BHC residues in raptor fat were $0.06 \mathrm{ppm}$ or less.

The only passerine tissue which lacked detectable residues of both lindane and BHC was the single food sample. Lindane was found in 1 whole body, 1 egg, 2 brain, and 4 fat samples; BHC occurred in 1 whole body, 2 egg, 13 brain, and 15 fat samples. Maximum levels of each compound ( $0.09 \mathrm{ppm})$ were found in fat samples of a snow bunting (lindane) and a horned lark (BHC).

\section{Miscellaneous Samples}

The only miscellaneous sample positive for either lindane or BHC was a composite of several whole snails that contained 0.01 ppm of lindane.

\section{Discussion}

Small amounts of alpha-BHC are formed as the major transformation product of the other BHC isomers; it is also metabolized more slowly by animals than lindane (Brooks 1974a). Thus, the 
BHC detected in our samples probably had its source in lindane, even in those cases where BHC occurred in the absence of lindane. The acute oral toxicity of BHC is much lower than that of lindane (Brooks 1974b), so it does not seem likely that the low levels found in our samples would be hazardous to wildife.

Compared with most organochlorines, lindane is outstanding for its speed of action and high acute toxicity to insects as a stomach, contact, or fumigant poison. With few exceptions, lindane has a lower lethal dietary toxicity to young bobwhite quail, Japanese quail, pheasants, and mallards than most of the commonly used organochlorine insecticides (Heath et al. 1972b).

Even though lindane is an organochlorine, with many of the negative characteristics of those compounds, its use as a seed treatment appears to be less hazardous to wild life and humans that might consume them than other organochlorines, such as heptachlor. Factors which favor seed treatment with lindane, rather than other organochlorines, include: it is applied to seed at only half the rate of heptachlor (BIus et al. 1979); it has a lower oral toxicity (Heath et al. 1972b); it is less persistent in the soil (Brooks 1974b); it is rapidly metabolized in animals (Brooks 1974b, Burrage and Saha 1972, Cummings et al. 1966, Stadelman et al.1965); it may repel granivorous animals (Schneider 1965); and, residue concentrations are reduced by some cooking methods (Ritchey et al. 1972). These factors should not preclude the use of even less environmentally damaging chemicals for seed treatment as they become available in the future.

Maximum lindane residues found in Montana wildlife were only a fraction of the USDA action level, and do not appear to pose a hazard to either wildlife or humans.

According to the MDA, approximately 3 times as many acres in Montana are planted with lindane-treated seed as with heptachlortreated seed. Despite this much greater usage, Iindane generally occurred at a much lower frequency and at considerably lower residue levels in our samples than HE. Because use of lindane as a seed treatment apparently does not result in wildlife losses, whereas other organochlorine insecticides have, lindane is preferred for this use.

Mirex

Mirex has been used primarily as a stomach poison in baits employed against ants (Brooks 1974a); it has little contact insecticidal activity.

Resident WiIdIife

The only mirex residues detected in resident wildlife $(0.01$ ppm) occurred in fat of a Hungarian partridge taken in April 1982 in Dawson County. 
Six fat and 1 meat sample from waterfowl contained mirex, with brain, cooked meat, food, and egg samples being negative. The positive meat sample had $0.02 \mathrm{ppm}$, while 4 of 6 positive fat samples contained $0.10 \mathrm{ppm}$ or more. The maximum mirex residue ( $6.01 \mathrm{ppm}$ ) was detected in a Dawson County mallard collected in April 1982 .

Mirex residues were found in only 2 fat samples from other aquatic birds and migratory game birds: $0.02 \mathrm{ppm}$ in a common loon and $0.07 \mathrm{ppm}$ in an eared grebe. Both were collected in Chouteau County in April 1982.

Residues of mirex were detected in 4 of the 6 raptor species sampled, but only in fat ( 9 of the 16) samples. These included 1 golden eagle $(0.47 \mathrm{ppm}), 1$ kestrel $(0.12 \mathrm{ppm}), 2$ red-tailed hawks $(0.07$ and $0.37 \mathrm{ppm})$, and 5 great horned owls $(0.04-0.44 \mathrm{ppm})$.

Mirex was detected in only 1 passerine sample, that being found in the fat of a cliff swallow (0.13 ppm).

\section{Miscellaneous Samples}

None of these samples contained detectable mirex residues.

\section{Discussion}

The most widespread use of mirex has been for control of the imported fire ant in the southeastern United States, where a common treatment involved 3 applications of 1.7 grams $(0.06$ oz) of mirex per acre over an 18-month period (Stickel et al. 1973). Despite those low application rates, fat samples of insectivorous birds collected 1 year after application contained up to $104 \mathrm{ppm}$ (wet weight) mirex (Baetcke et al. 1972).

Toxicity of mirex to mammals was reported to be approximately half that of chlordane (Brooks 1974b), although stickel et al. (1973) cited other studies indicating that relatively low dietary levels of mirex have serious effects on some species.

Mirex was formerly (but is not currently) recommended for harvester ant control in Montana. Recommended application rates were 3.4 grams per acre, not to exceed 1 application in any 2 month period, or 3 applications in any 12 month period (Montana Cooperative Extension Service 1975). Because mirex is exceptionally stable, with a half-life of nearly 7 months in birds (Stickel et al. 1973), its recent use in Montana could account for the minor residue present in the Hungarian partridge. However, it appears that nearly all mirex residues found in our samples were obtained outside of Montana. Based on the conclusions of Stickel et al. (1973), and the residue levels found, it 
does not appear that mirex is a hazard to Montana wildife or people eating them.

\section{MAJOR ACTIONS}

Several major actions, at the state and national levels, resulted from 1981 endrin applications in Montana. The first was increased awareness by technical personnel of the documented and potential hazards of endrin to Montana's fish and wildlife resources, and to consumers of those resources.

As a result of that awareness, at least 2 professional wildlife groups enacted resolutions calling for the immediate and permanent termination of the use of endrin (Appendix $K$ and $L$ ). One of those groups included strychnine in its resolution while the other included heptachlor. Both groups supported concurrent research efforts to develop alternative methods of pest control. The Central and Pacific Flyway Councils adopted resolutions, at annual meetings in March 1982, which encouraged the development and implementation of effective and economical alternative controls for cutworms which minimize hazards to wildlife (Appendix M).

The second, and perhaps most significant, action was increased public awareness about pesticides. Consumption of pesticide-contaminated game meat became a primary concern during the fall of 1981; the endrin issue was selected by the news media as the number 2 news story in Montana that year (Appendix $N$ ). That awareness carried through 1982 and resulted in demands by the public for better safeguards for the use of pesticides in general (Appendix 0 ).

A third action involved the decision by the Montana Fish and Game Commission to delay the opening of the 1981 goose season in 8 southeastern counties for 6 weeks (Appendix P). For the first time since its establishment in 1901, the Commission delayed the opening of a hunting season because of pesticide-contamination of game animals. The Commission also issued precautionary statements on trimming of fat, cooking procedures, and limitations on consumption of sharptails, partridge, and waterfowl in 1981, 1982 and 1983. Similar advisories had been issued by previous Commissions concerning DDT residues in forest grouse in the early $1960^{\prime}$ s, and mercury in farmland game birds in 1969.

Fourth, the Governor of Montana appointed a 12-member Citizens Pesticide Advisory Council in November 1981, with equal representation from agriculture, the pesticide industry, the medical profession, and wildlife interests. The general purpose of that council was to study and make recommendations to the Director of the MDA on specific pesticide problems in Montana; two of those pesticides were endrin and strychnine. The Council also evaluated the Montana Pesticide Act, rules adopted to 
implement the Act, and the pesticide registration, enforcement, monitoring, and certification programs in the state. After two 2-day sessions, the council recommended a series of more restrictive pesticide regulations, the following of which were adopted by the MDA after public hearings:

1. the registration of endrin for grasshopper control in grain fields was cancelled;

2. the addition of a requirement that any use of endrin by a permitted farm applicator be reported to MDA within 7 days of such use;

3. commercial applicators and pesticide dealers must submit monthly, rather than annual, reports of pesticide sales.

The 1981 endrin issue in Montana was also largely responsible for the collective request by 4 national conservation organizations (National Audubon Society, Environmental Defense Fund, National Wildlife Federation, and Izaak Walton League of America) for cancellation of all registrations of endrin by the U.S. Environmental Protection Agency (Appendix Q).

In March 1983, the Montana Fish and Game Commission adopted a resolution (Appendix $R$ ) requesting governmental pesticide regulatory agencies to authorize and recommend environmentally safe and less persistent alternatives to chlorinated hydrocarbons. They also supported research efforts to evaluate the effectiveness of those alternatives and the immediate phaseout of the persistent compounds when the alternatives become available.

The most recent action was the agreement by the EPA to fund a cooperative field study of the effects of endrin and chlorpyrifos on waterfowl, upland game birds, and perhaps passerine birds. That study, by the MDA and Brigham Young University personnel, was conducted in March-July 1983 in Fergus County, Montana. 


\section{CONCLUSIONS}

\section{Endrin Monitoring}

Endrin and toxaphene treatments in March 1981 each resulted in a documented fish kill in southeastern Montana. These events generated concern for fish and other wildlife in other endrintreated areas of the state. Primary sampling emphasis following 1981 endrin applications in Montana concentrated on evaluation of endrin residues in surviving or immigrant wildlife on and around treated areas. Residue data from vegetation and wildlife permitted assessing the impacts on local wildlife populations in broad terms as well as providing data for evaluation of human health concerns by authorities in that field.

\section{Implications to Wildlife}

Sufficient time elapsed between endrin treatment and subsequent random fish sampling at 29 sites statewide so that only $23 \%$ of fish samples contained detectable endrin residues. The presence of endrin in fish samples indicates endrin's persistence (at least short-term) in fish, even though the endrin may have been diluted significantly in large bodies of standing water or in flowing streams.

Early 1981 endrin applications resulted in widespread assimilation by, and endrin-contamination of Montana wildlife. Maximum endrin residues in fat samples of various wildlife groups tested were: big game $(N=79), 0.53 \mathrm{ppm}$ in a pronghorn; upland game birds $(\mathrm{N}=106), 22.9 \mathrm{ppm}$ in a sharp-tailed grouse; small mammals $(N=18), 0.01 \mathrm{ppm}$ in a cottontail rabbit; waterfowl $(\mathrm{N}=291), \quad 2.56 \mathrm{ppm}$ in a ruddy duck; other aquatic birds and migratory game birds $(N=33), 0.64 \mathrm{ppm}$ in a coot; raptors $(\mathbb{N}=14)$, $0.33 \mathrm{ppm}$ in a harrier; and passerines $(\mathbb{N}=14), 0.16 \mathrm{ppm}$ in a horned lark. Maximum endrin residues detected in tissues other than fat included $0.75 \mathrm{ppm}$ in the meat of a sharp-tailed grouse, $0.30 \mathrm{ppm}$ in the brain of a sharptail, $0.14 \mathrm{ppm}$ in the liver of a ground squirrel, $0.03 \mathrm{ppm}$ in the whole body of a deer mouse, 2.54 $\mathrm{ppm}$ in the crop contents of a sharptail, and $0.01 \mathrm{ppm}$ in a mallard egg.

While endrin residues were relatively low in most resident wildlife species, they did occur in a variety of species and were especially notable in sharp-tailed grouse; 55\% of all sharptail samples ( 27 of 54 fat, 6 of 9 meat, 2 of 2 liver, 1 of 1 brain, and 1 of 1 food) contained endrin. Because of their limited mobility, we conclude that resident wildlife obtained their endrin residues locally. 
The apparent absence of high endrin residues in farmland game birds, such as the pheasant and Hungarian partridge, was attributed to one or more of the following factors: limited use of newly growing wheat by these species, mortality of individuals exposed to endrin treatments and their subsequent unavailability for sampling, sampling of individuals moving into treated areas from surrounding untreated areas, and sampling of some individuals from known or suspected untreated areas. Known endrin toxicity to upland game birds closely associated with croplands precluded much chance for their survival from direct endrin exposure.

Detectable endrin residues in flightless juvenile ducks, elevated endrin levels in many other species, and the continued detection of endrin in these species at the same sites for over 1 year supports a conclusion of local endrin sources. Endrin residues in nearly half ( $48 \%$ ) of all samples from migratory birds associated with aquatic habitats suggests endrin may also have been obtained outside of Montana.

The frequency of occurrence of detectable endrin residues in migratory birds usually associated with upland habitats (over 52\% of raptors and $35 \%$ of passerines, including mourning doves) collected 7-8 months after endrin application also supports a conclusion of Montana sources of endrin.

Endrin residues in small mammals, upland game birds, and migratory birds were, and may continue to be available for ingestion by avian and mammalian predators. Evaluation of the effects of those residues, or of 12-ketoendrin residues, on those species was not attempted.

The occurrence of endrin residues in wildlife during the summer, fall, and winter of 1981, and even through the summer of 1982 at some sites, suggests that either endrin persists in the environment (eg. soil or pond sediments) for at least 15 months in eastern Montana, or detectable endrin residues persist in wildlife tissues for a similar time period. Based on the semiarid, continental climate and high clay content of soil, the semi-closed pond ecosystems in eastern Montana, and the limited information concerning elimination of endrin from animals, we conclude that endrin's environmental persistence results in its prolonged availability to wildlife in Montana.

The magnitude of Montana's contribution to endrin contamination of international migratory bird populations in 1981 was not assessed in these studies. Such an evaluation would have encompassed knowledge of: the extent and amounts of endrin usage on a state-by-state basis; knowledge of bird population levels, characteristics, and habitats for selected species; testing of individual birds from treated and untreated sites; and the testing of individual birds during the various seasons and in many states and provinces. 
Implications to Wildlife Management

The total impact of 1981 endrin applications on local wildife populations in Montana will remain unknown. Annual losses of wildlife to endrin (or any other spring-applied pesticide) are largely in addition to natural mortality, and occur when population levels are at annual lows.

Significant direct costs for these studies (approximately $\$ 262,000$ ) were borne by the MDFWP, and thus by Montana hunters. In addition to these costs, the MDFWP experienced an estimated minimum loss of $\$ 116,000$ in reduced license sales and federal aid funding during 1981 and 1982. The funds, and time, involved in those studies were unbudgeted and therefore represent losses in other important wildlife management and research activities.

Surveys indicated a significant proportion ( $98 \%$ ) of 1982 resident game bird license buyers in Montana were aware of potential pesticide contamination of wildlife. One-third of this group did not hunt upland game birds and two-thirds did not hunt waterfowl in 1982; $30 \%$ of each group indicated their reason for not hunting was possible pesticide contamination of game meat. Those proportions, and the numbers of hunters they represent, are considered minimums because we do not know exactly how many individuals who normally purchase hunting licenses did not do so in 1982 and therefore were unavailable for the telephone survey. More than $90 \%$ of those that did hunt in 1982 indicated that the warnings about preparing and cooking game birds were heeded.

Although the endrin label warns (1) that it is toxic to fish and wildlife, (2) to keep it out of lakes, ponds, and streams, (3) not to contaminate water by cleaning of equipment or disposal of wastes, and (4) not to apply it where runoff is likely to occur, we conclude that endrin label restrictions do not adequately protect fish and wildlife. The repeated occurrence of endrin residues in wildlife tissues at the same sites for up to 15 months post-application shows that those restrictions are ineffective in preventing such contamination.

Implications to Human Health

The recent endrin issue is the third instance in which Montanan's have been warned of potential hazards from consuming pesticide-contaminated wildlife; others have included DDT residues in forest wildlife in the mid-1960's and mercury in farmland game birds in 1969-1970. Since the 1981 endrin issue in Montana involved migratory as well as resident wildlife, it generated concern for human consumability of pesticidecontaminated wildlife in other states as well as at the national level. In each case where consumability of wildlife has been in question, the lack of established tolerance levels, action levels, or ADI's for wild meat was at the heart of that concern, and the MDFWP was forced to rely on opinions of federal and state health experts for evaluating those concerns. We conclude that 
the Fish and Game Commission would be in a much better position to quickly and decisively respond to such situations if action levels were established for pesticide residues in wild game meat.

Endrin residues in some upland game birds and waterfowl were sufficiently high to justify concern by the MDFWP for ingestion of those residues by people, and for the precautionary warnings issued by the Montana Fish and Game Commission about preparing and cooking those birds. Endrin residues in $15 \%$ of all sharptailed grouse samples ( $27 \%$ of the endrin-positive samples) exceeded USDA action levels for domestic meats. Action levels were also exceeded in $7 \%$ of all waterfowl samples. Although many of the samples were taken in the summer, endrin residues in those species just prior to and during fall hunting seasons also exceeded the action levels. The federal government would embargo domestic meats contaminated with similar endrin levels, and not allow it to be sold for public consumption.

The delayed opening of the 1981 Canada goose hunting season in southeastern Montana was the strongest action taken by a Montana Fish and Game Commission in reaction to pesticide contamination of wildlife. That action alerted hunters and the general public to the seriousness of endrin contamination of waterfowl in Montana. While the Commission's cautionary warnings to Montana hunters are not new, they also are not traditional, and apparently discouraged many from hunting. We conclude that significant losses of hunter opportunity and traditional values occur when hunters are forced to alter their habits to avoid ingesting potentially hazardous chemicals.

\section{Alternative Insecticide-Wildlife Study}

Aquatic

Aerially applied endrin was lethal to all test organisms within 2 hours for at least 1,185 feet downwind from the test plot. We conclude that it would be harmful to aquatic organisms beyond the $1 / 4 \mathrm{mi}(1,320 \mathrm{ft})$ buffer zone around public waters stipulated by label restrictions.

Permethrin was toxic to test organisms for a considerable distance downwind from the treated area, but mortality figures were confused by weather factors. Toxicity of chlorpyrifos to aquatic organisms was not tested. Based solely on toxicity to fish, chlorpyrifos and permethrin are preferable to endrin, while chlorpyrifos may be preferable to permethrin where the potential for contamination of water exists.

\section{Terrestrial}

Small mammal mortality was documented shortly after 1982 endrin spraying. Test results indicated that similar losses may 
have been experienced by small birds inhabiting endrin-treated areas. The magnitude and extent of those losses are unknown.

Residue data indicated that reproduction of small birds and mammals was probably impaired by endrin applications. Limited data suggested that waterfowl may have been similarly affected.

Brain chlorinesterase levels in small birds collected at intervals following chlorpyrifos applications indicated some possible losses of small birds on these areas.

In contrast to endrin and chlorpyrifos, permethrin did not appear to adversely affect terrestrial wildiife where all 3 were applied in the same vicinity. In conclusion, our studies indicate that, from the standpoint of terrestrial wildlife, permethrin is preferred over endrin or chlorpyrifos for control of cutworms. Whether permethrin's safety regarding terrestrial wildlife outweighs its potentially greater hazard to aquatic wildife where there is a possibility for contamination of water bodies is probably best determined on a case-by-case basis.

\section{Other Chlorinated Hydrocarbon Conpounds}

Detectable residues of 17 other organochlorine compounds in Montana wildlife tissues suggested that wildlife did assimilate a variety of hazardous substances introduced into their environment. The number of species and habitats involved indicates that sources of some of these compounds are indeed widespread. These conclusions are supported by the following maximum residues found in the fat of various migratory and resident wild ife species: $0.25 \mathrm{ppm}$ heptachlor in a harrier, $53.0 \mathrm{ppm} \mathrm{HE}$ in a mourning dove, $50.1 \mathrm{ppm}$ PCB in a blue-winged teal, $0.82 \mathrm{ppm}$ alpha-chlordane in a shoveler, $0.68 \mathrm{ppm}$ gamma-chlordane in a mallard, $0.37 \mathrm{ppm}$ betanonachlor in an eared grebe, $0.60 \mathrm{ppm}$ trans-nonachlor in a mourning dove, $2.23 \mathrm{ppm}$ oxychlordane in a horned lark, $8.27 \mathrm{ppm}$ DDT in a pintail, $1.00 \mathrm{ppm}$ DDD in a white pelican, 33.7 ppm DDE in a harrier, $2.08 \mathrm{ppm}$ dieldrin in a red-tailed hawk, $3.95 \mathrm{ppm}$ HCB in a vesper sparrow, $0.09 \mathrm{ppm}$ lindane in a great horned owl and a snow bunting, $0.32 \mathrm{ppm}$ BHC in a long-eared owl, and 6.01 ppm mirex in a mallard.

The detection of at least 13 organochlorine compounds in a single mallard in April suggests that some contaminants are obtained outside of Montana. Elevated levels of individual compounds (eg. $47.10 \mathrm{ppm} \mathrm{HE}$ and $23.60 \mathrm{ppm}$ DDE) support that suggestion. However, detectable levels of 8 parent organochlorine compounds (endrin, heptachlor, PCB'S, DDT, dieldrin, $\mathrm{HCB}, \mathrm{BHC}$, and mirex) in resident wildlife indicates that Montana contributes to the nationwide contamination of wildlife with each of those compounds and their isomers/metabolites. 
Treatment of cereal grain seed with heptachlor $(\simeq 177,000 \mathrm{~A}$ in 1981) has led to widespread heptachlor epoxide contamination of Montana wildlife. Over one-fourth of all upland game bird samples contained detectable $\mathrm{HE}$ residues, and $5 \%$ of those residues exceeded FDA action levels. HE residues were found in small mammals from every sample site. A large percentage of samples (34-90\%) from migratory bird groups contained detectable HE, including several individuals that exceeded $10 \mathrm{ppm}$ in their fat.

Test results indicated that direct mortality of wild Iife, especially raptors, probably has resulted from heptachlor use in Montana. Those data also suggested that impaired reproduction has occurred in some bird groups (eg. waterfowl, raptors) and small mammals.

Lind ane

Despite the widespread use of lindane ( $\simeq 450,000 \mathrm{~A}$ in 1981) in Montana, less than $5 \%$ of all samples tested contained lindane (maximum of $16 \%$ of upland game birds). Maximum lindane residues (0.11 ppm in the brain of a deer mouse) do not appear to pose problems to wildlife or to humans that might consume lindanecontaminated game. We conclude that from a wildife standpoint lindane is much better than heptachlor as a seed treatment to protect cereal grains from wireworms.

PCB'S

PCB residues were relatively widespread among migratory species. Their presence in resident species indicated at least some local exposure. PCB residues did not appear to occur at acutely toxic levels in birds; since mink, and possibly other mustelids are especially sensitive to PCB's, the situation with mammals was less clear. The principal hazard to both birds and mammals appears to be adverse physiologic changes resulting from chronic low-level dietary exposure.

Detectable PCB residues occurred in waterfowl year-round, with maximums of $50.10 \mathrm{ppm}$ in May, $2.41 \mathrm{ppm}$ in June, $4.44 \mathrm{ppm}$ in October, and $5.82 \mathrm{ppm}$ in February. The hazard to humans of consuming waterfowl with PCB levels of this magnitude is unknown.

DD T

Detection of DDT in a few fat samples from resident wildife indicated recent availability of that compound in Montana, even though its use in the United States has been banned since 1972. DDE residues were detected in $27 \%$ of all resident wildlife samples tested, which indicated either recent DDT use or DDE persistence in the environment for nearly a decade after a major reduction of the use of DDT. 
Among migratory birds, passerines had the lowest frequency of occurrence of DDT-complex residues, while raptors had the highest. Waterfowl and other aquatic birds and migratory game birds were intermediate. DDE was encountered most frequently (76-100\% frequency of occurrence among groups), followed by DDT $(5-25 \%)$ and DDD $(2-5 \%)$.

Residues of the DDT group in Montana wildlife did not occur at levels high enough to result in direct mortality. However, frequencies of occurrence and elevated residue levels of DDE detected in birds is of major concern. While eggshell thinning, a phenomenon apparently peculiar to DDE, is not manifested severely in upland game birds (gallinaceous birds), it does significantly impact the reproduction of waterfowl and flesh-and fish-eating birds, including several endangered species.

DDE-caused eggshell thinning has been responsible for greatly reduced populations of bald eagles and peregrine falcons, including extinction of peregrines as a nesting species east of the Mississippi River. Other bird species have been similarly affected. MDFWP surveys have determined that only about 40 nesting pairs of bald eagles exist in Montana, and the Department is actively engaged in attempting to reestablish breeding populations of peregrines through introduction of flightless young hatched in captivity. Should these birds continue to accumulate DDT and/or its metabolites, their fate may be no different than the birds they were meant to replace, and costly artificial augmentation of their populations would be required indefinitely. The appearance of DDT group compounds in prey species of eagles and peregrines justifies our concern for their future welfare in Montana.

Dieldrin

Dieldrin occurred at relatively low frequencies in resident wildlife samples ( $7 \%$ in small mammals and $22 \%$ in upland game birds) and all were at low levels (0.18 ppm or less). Those data indicated Montana sources of dieldrin for some wildlife populations.

Twenty-two percent of the passerine bird samples and 49-60\% of all samples from other migratory birds contained detectable dieldrin. While most samples had relatively low levels of dieldrin, 2 ducks ( 1 each in winter and spring) had residues exceeding USDA action levels. Raptors were the most heavily contaminated wildlife group, with maximum dieldrin levels of 0.77-2.08 ppm in 4 species. Maximum dieldrin residues in Montana wildlife were below those considered hazardous to wildlife, and were mostly obtained outside of the state.

\section{Other Compounds}

Although occasionally occurring at high levels and/or frequencies, residues of hexachlorobenzene, benzene hexachloride, mirex, and chlordane and its metabolites were quite low in 
wildife samples. Levels of these compounds do not appear to be hazardous to either wildlife or humans.

The detection of residues of other chlorinated hydrocarbon compounds expanded our concern for the effects of those compounds on wildife, and consumability of wild meat. The latter was especially pertinent because of the documented carcinogenicity of heptachlor/HE and potential human afflictions caused by some of the other compounds. Another remaining concern is the largely unstudied and little understood potential for synergistic effects of these compounds with one another, or with other groups of insecticides (eg. organophosphates, carbamates), herbicides, or other compounds such as heavy metals. As an example, the fat of an adult male mallard collected in April 1982 contained a total of $81.35 \mathrm{ppm}$ of $13 \mathrm{different}$ chlorinated hydrocarbons. It is doubtful whether anyone can state with any degree of certainty what the combined effects are on birds carrying such residue burdens, or on predators (including humans) which might consume them. 


\section{RECOMMENDATIONS}

1. The manufacture and use of endrin and heptachlor should be immediately and permanently terminated. The availability of efficacious, alternative methods of cutworm and wireworm control (including permethrin and lindane, respectively) indicate that endrin and heptachlor and the hazards they pose to wildife and human health are no longer needed.

2. When a pesticide's registration for use is cancelled for human health or other reasons, all use of that pesticide should be terminated immediately. Continued use of existing inventories of such hazardous compounds promotes and abets continued exposure of people and wildlife to the compound for economic convenience. Continued use prolongs risks to human health and disrupts state and federal wildlife management programs. Cancellation actions should include provisions for location, retrieval, and safe disposal of existing inventories of the compound, and reimburse producers, dealers, and applicators for those inventories.

3. Additional field research into alternative methods of cutworm, wireworm, and other pest insect control is needed. A 20-year old Presidential Committee recommended (President's Science Advisory Committee 1963:21):

"In order to develop safer, more specific controls of pests, it is recommended that Government-sponsored programs continue to shift their emphasis from research on broadspectrum chemicals to provide more support for research on (a) Selectively toxic chemicals. (b) Nonpersistent chemicals. (c) Selective methods of application. and (d) Nonchemical control methods such as the use of attractants and the prevention of reproduction."

Research on those alternatives should include:

a. developing and evaluating highly selective insecticides (those which kill economically damaging species but not the pest's natural enemies or other nontarget wildlife);

b. developing and evaluating nonlethal control chemicals (such as deterrents or behavioral modifiers which interrupt mating cycles, oviposition, sociality, dispersal, aggregation, etc.); and

c. evaluating crop rotations, trap or lure crops, tillage practices, livestock grazing, and burning with respect to their effects on pest insects. 
4. A cooperative working group of technicians from the Montana Departments of Agriculture; Fish, Wildlife and Parks; and Health and Environmental Sciences should be established to:

a. review existing registered pesticides and their potential impacts on environmental components and human health and to identify suitable alternatives;

b. evaluate any new pesticide considered for first-time registration in Montana;

c. initiate a pesticide reporting system that establishes an "action plan" for addressing unforeseen problems such as severe pest outbreaks or significant use of pesticides that might impact wildife or human health;

d. maintain close liaison with the Montana Agricultural Experiment Station, the Cooperative Extension Service, the U.S. Fish and Wildiife Service, and the EPA, concerning pesticide studies, registrations, and research needs; and

e. develop and maintain close coordination on pesticidefish and wildife-human health research efforts in Montana.

5. Additional testing for residues of chlorinated hydrocarbons in resident and migratory wildlife in Montana should be implemented on a periodic basis (i.e. every 2-3 years). That program is needed to determine when the current warnings on consumption of wildlife can be lifted.

6. Action levels for pesticide residues hazardous to humans should be established for wild game meat. Those guidelines would have significant value to state health and wildife agencies in their decisions concerning the hunting, sale, and consumption of $\mathrm{fish}$ and game.

7. The Environmental Protection Agency should accelerate its efforts to eliminate sources of hazardous pesticides available to wildife and people.

8. The cautionary warnings established by the Montana Fish and Game Commission for upland gamebirds and waterfowl in 1981 should be issued annually prior to the opening of those respective hunting seasons until residue test results reflect potential risks to human health from consuming those species have subsided to safer levels. We further recommend that bird hunters avoid hunting in the vicinity of any croplands that have been treated with endrin or heptachlor. 
9. The manufacture of DDT should be banned in the United States as well as globally. The high residues and frequency of occurrence of DDE in migratory birds in Montana indicates that DDT is being used elsewhere in the United States or in other North, Central, or. South American countries.

10. There should be efforts at the national level to establish and fund a cooperative state-federal program to expand research and monitoring efforts on pesticides and their effects on agricultural production, human health, and wildlife. 


\section{LITERATURE CITED}

Anderson, D.W., and J.J.Hickey. 1976. Dynamics of storage of organochlorine pollutants in herring gulls. Env. Poll. $10: 183-200$.

Anderson, W.L., R.E. Greenberg, R.E. Duzan, and M.A. Kjos. 1970. Concentrations and distributions of p,p'-DDE, dieldrin and heptachlor epoxide in pheasants in east-central Illinois. Trans. Ill. St. Acad. Sci. 63(4):373-382.

Anonymous. 1968. Acute poisoning by pesticides: Bovine endrin poisoning. Pp. 21-22 In Community Pesticide Study, Quart. Rept. for period ending June 15, 1968, Greeley, Colo.

Argyle, R.L., G.C. Williams, and H.K. Dupree. 1973. Endrin uptake and release by fingerling channel catfish (Ictalurus punctatus). J.Fish. Res.Bd. Can. 30:1743-1744.

Baetcke, K.P., J.D. Cain, and W.E. Poe. 1972. Mirex and DDT residues in wildlife and miscellaneous samples in Mississippi--1970. Pest. Monit.J. 6(1):14-22.

Bagley, G.E., and E. Cromartie. 1973. Elimination pattern of Aroclor 1254 components in the bobwhite. J. Chromatog. $75: 219-226$.

Bain, 0. 1983. Endrin: chronology of a controversy. Western Wild lands $9(1): 20-25$.

Balph, M.H., L.C. Stoddart, and D.F. Balph. 1977. A simple technique for analyzing bird transect counts. Auk $94(3): 606-607$.

Barrett, G.W., and R.M. Darnell. 1967. Effects of dimethoate on small mammal populations. Amer. Midl. Nat. 77(1):164-175.

Baxter, W.L., R.L. Linder, and R.B. Dahlgren. 1969. Dieldrin effects in two generations of penned hen pheasants. J. Wildl. Manage. 33(1):96-102.

Bedford, C.T., D.H. Hutson, and I.L. Natoff. 1975a. The acute toxicity of endrin and its metabolites to rats. Tox. and Appl. Pharm. 33:115-121.

R.K. Harrod, E.C. Hoadley, and D.H. Hutson. 1975 b. The metabolic fate of endrin in the domestic rabbit. Xenobiotica 5(8): 485-500. 
Belisle, A.A., W.L. Reichel, L.N. Locke, T.G. Lamont, B.M. Mulhern, R.M. Prouty, R.B. DeWolf, and E. Cromartie. 1972. Residues of organochlorine pesticides, polychlorinated biphenyls, and mercury and autopsy data for bald eagles, 1969 and 1970. Pest. Monit. J. 6(3):133-138.

Belirose, F.C. 1976. Ducks, geese and swans of North America. Wildl. Manage. Inst. and Ill. Nat. Hist. Surv., Stackpole Books, Harrisburg, Penn. 540 pp.

Bennett, R.S., Jr., and H.H. Prince. 1981. Influence of agricultural pesticides on food preference and consumption by ring-necked pheasants. J. Wildl. Manage. 45(1):74-82.

Bernard, R.F. 1963. Studies on the effects of DDT on birds. Mich. St. Univ., Biol. Ser. 2(3): 159-191.

Best, L.B. 1970. Effects of ecological changes induced by various sagebrush control techniques on non-game birds. M.S. Thesis, Mont. St. Univ., Bozeman. 74 pp.

Blus, L.J. 1982. Further interpretation of the relation of organochlorine residues in brown pelican eggs to reproductive success. Env. Poll. (Ser. A) 28:15-33.

_- C.J. Henny, D.J. Lenhart, and E. Cromartie. 1979. Effects of heptachlor-treated cereal grains on Canada geese in the Columbia Basin. Pp. 105-116 In Management and biology of Pacific Flyway geese: a symposium. R.L. Jarvis and J.C. Bartonek, eds., Ore. St. Book Stores, Inc., Corvallis.

0.H. Patee, C.J. Henny, and R.M. Prouty. 1983. First records of chlordane-related mortality in wild birds. J. Wildl. Manage. 47(1):196-198.

Boddicker, M.L., E.J. Hugghins, and H.R. Richardson. 1971. Parasites and pesticide residues of mountain goats in South Dakota. J. Wildl. Manage. 35(1):94-103.

Broadley, R.H., and P.D. Rossiter. 1979. Insecticide trial against the common armyworm, Pseudaletia convecta (Walker) (Lepidoptera:Noctuidae). Queensland J. Agric. \& Animal Sci. $36(1): 91-92$.

Brooks, G.T. 1974a. Chlorinated hydrocarbon insecticides. Vol. I. Technology and application. CRC Press, Boca Raton, Fla. $249 \mathrm{pp}$.

- 1974b. Chlorinated hydrocarbon insecticides. Vol. II. Biological and environmental aspects. CRC Press, Boca Raton, Fla. $197 \mathrm{pp}$. 
Burrage, R.H., and J.G. Saha. 1967. Insecticide residues in spring wheat plants grown in the field from seed treated with aldrin or heptachlor. Can. J. Plant Sci. 47(1):114115 .

, and 1972. Insecticide residues in pheasants after being fed on wheat seed treated with heptachlor and ${ }^{14} \mathrm{C}$ lindane. J. Econ. Ent. 65(4): 1013-1017.

Cain, B.W. 1981. Nationwide residues of organochlorine compounds in wings of adult mallards and black ducks, 1979-80. Pest. Monit. J . 15(3):128-134.

Carson, R. 1962. Silent Spring. Houghton Mifflin Co., Boston, Mass. $368 \mathrm{pp}$.

Cecil, H.C., G.F. Fries, J.Bitman, S.J.Harris, R.J. Lillie, and C.A. Denton. 1972. Dietary p, $p^{\prime}-D D T, o, p^{\prime}-D D T$, or $p, p^{\prime}-D D E$ and changes in eggshell characteristics and pesticide accumulation in egg contents and body fat of caged white leghorns. Poultry Sci. 51:130-138.

Cheng, H.H. 1980. Toxicity and persistence of pyrethroid insecticides as foliar sprays against darksided cutworm (Lepidoptera: Noctuidae) on tobacco in Ontario. Can. Ent. $112: 451-456$.

Cholakis, J.M., M.J. McKee, L.C.K. Wong, and J.D. Gile. 1980. Acute and subacute toxicity of pesticides in microtine rodents. Pp. 143-154 In Avian and mammalian wildlife toxicology: second conference. E.E. Kenaga and D.W. Lamb, Eds. ASTM STP 757. 164 pp.

Clark, D.R., and T.G. LaMont. 1976. Organochlorine residues in females and nursing young of the big brown bat (Eptesicus fuscus). Bull. Env. Contam. Tox. 15(1): 1-8.

and R.M. Prouty. 1977. Experimental feeding of DDE and PCB to female big brown bats (Eptesicus fuscus). J. Tox. Env. Health 2:917-928.

R.K. Laval, and D.M. Swineford. 1978. Dieldrin-induced mortality in an endangered species, the gray bat (Myotis grisescens). Am. Assoc. Adv. Sci. 199:1357-1359.

and A.J.Krynitsky. 1980. Dieldrin and heptachlor residues in dead gray bats, Franklin County, Missouri--1976 versus 1977. Pest. Monit. J. 13(4):137-140.

Clawson, S.G., and M.F. Baker. 1959. Immediate effects of dieldrin and heptachlor on bobwhites. J. Wildl. Manage. $23(2): 215-219$. 
Cole, H., D. Mackenzie, C.B. Smith, and E.L. Bergman. 1968. Influence of various persistent chlorinated insecticides on the macro and micro element constituents of Zea mays and Phaseolus vulgaris growing in soil containing various amounts of these materials. Bull. Env. Contam. Tox. 3:141i53.

Colorado Department of Agriculture. 1968. Endrin poisoning cases. Memorandum from R.I. Sullivan to C.E. Jeffers and W. Snyder. 20 June 1968.

Cooley, R.A., and J.R. Parker. 1916. The army cutworm in Montana. Mont. Agric. Coll. Exp. Sta., Bozeman, Circ. 52:97108 .

Cope, 0.B. 1965. Contamination of the freshwater ecosystem by pesticides. J.Appl. Ecol. 3(Suppl.):33-44.

Cromartie, E., W.L. Reichel, L.N. Locke, A.A. Belisle, T.K. Kaiser, T.G. Lamont, B.M. Mulhern, R.M. Prouty, and D.M. Swineford. 1975. Residues of organochlorine pesticides and chlorinated biphenyls and autopsy data for bald eagles, 1971-72. Pest. Monit. J.9(1):11-14.

Cummings, J.G., K.T. Zee, V. Turner, F. Quinn, and R.E. Cook. 1966. Residues in eggs from low level feeding of five chlorinated hydrocarbon insecticides to hens. J. Assoc. Offic. Analyt. Chem. 49(2):354-364.

M. Eidelman, V. Turner, D. Reed, K.T. Zee, and R.E. Cook. 1967. Residues in poultry tissues from low level feeding of five chlorinated hydrocarbon insecticides to hens. J. Assoc. Offic. Analyt. Chem. 50(2):418-425.

Custer, T.W., and G.H. Heinz. 1980. Reproductive success and nest attentiveness of mallard ducks fed Aroclor 1254. Env. Poll. (Ser. A) 21:313-318.

Dahlgren, R.B., and R.L. Linder. 1971. Effects of polychlorinated biphenyls on pheasant reproduction, behavior, and survival. J.Wildl. Manage. 35(2):315-319.

_..., Y.A. Greichus, and R.L. Linder. 1971. Storage and excretion of polychlorinated biphenyls in the pheasant. J. Wildl. Manage. 35(4):823-828.

R.J. Bury, R.L. Linder, and R.F. Reidinger, Jr. $1972 a$. Residue levels and histopathology in pheasants given polychlorinated biphenyls. J. Wildl. Manage. 36(2):524 533.

R.L. Linder, and W.L. Tucker. 1972b. Effects of stress on pheasants previously given polychlorinated biphenyls. J. Wildl. Manage. 36(3):974-978. 
de Freitas, A.S.W., J.S. Hart, and H.V. Morley. 1969. Chronic cold exposure and DDT toxicity. Pp. 361-366 In Chemical Fallout: current research on persistent pesticides. M.W. Miller and G.G. Berg, Eds., Chas. C. Thomas, Publisher, Springfield, Ill. 531 pp.

DePew, L.J. 1980. Pale western cutworm: chemical control and effect on yield of winter wheat in Kansas. J. Econ. Ent. $73: 138-140$.

DeWitt, J.B. 1956. Chronic toxicity to quail and pheasants of some chlorinated insecticides. J.Agric. Food Chem. $4(10): 863-866$.

Dieter, M.P. 1974. Plasma enzyme activities in Coturnix quail fed graded doses of DDE, polychlorinated biphenyl, malathion and mercuric chloride. Tox. \& Appl. Pharm. 27:86-98.

Dustman, E.H., L.F. Stickel, L.J. Blus, W.L. Reichel, and S.N. Wiemeyer. 1971. The occurrence and significance of polychlorinated biphenyls in the environment. Trans. N. Am. Wildl. \& Nat. Res. Conf. 36:118-133.

Egan, H. 1972. Pesticides in the environment and their significance. Pp 140-159 In Toxicology, biodegradation and efficacy of livestock pesticides.M.A.Khan and W.O. Haufe, Eds., Swets \& Zeitlinger, Amsterdam. 433 pp.

Ellman, G.L., K.D. Courtney, V. Andres, Jr., and R.M. Featherstone. 1961. A new and rapid colorimetric determination of acetylcholinesterase activity. Biochem. Pharmacol. $7: 88-95$.

Environmental Protection Agency. 1976. Chlordane and heptachlor in relation to $\mathrm{man}$ and the environment. A further pesticide review, 1972-1975. EPA-540/4-76-005. $85 \mathrm{pp}$.

1978. Endrin: Position Document 2/3. Office of Pesticide Programs, Special Pesticides Review Division, Washington, D.C. $205 \mathrm{pp}$.

- 1980a. Ambient water quality criteria for endrin. Office of Water Regulations and Standards, Criteria and Standards Division. Washington, D.C. EPA 440/5-80-047. 95 pp.

1980b. DRAFT--Summary of reported incidences involving endrin. Pesticide Incident Monitoring System, Report. No. 394. $56 \mathrm{pp}$.

Federal Register. 1976. Environmental Protection Agency. Velsicol Chemical Co. et al. Consolidated heptachlor/chlor dane hearing. $41(34): 7552-7585$. 
1979. Endrin: Intent to cancel registrations and denial of applications for registration of pesticide products containing endrin, and statement of reasons, Part II. $44(144): 43632-43657$.

Feist, F.G. 1968. Breeding bird populations in relation to proposed sagebrush control in central Montana. M.S. Thesis, Mont. St. Univ., Bozeman. 41 pp.

Ferguson, D.E. 1964. Some ecological effects of heptachlor on birds. J. Wildl. Manage. 28(1): 158-163.

Flath, D.L. 1981. Vertebrate species of special interest or concern: mammals, birds, reptiles, amphibians, fishes. Mont. Dept. Fish, Wildl. \& Parks, Wildl. Div. Rept. 74 pp.

Fleming, W.J., M.A.R. McLane, and E. Cromartie. 1982. Endrin decreases screech owl productivity. J. Wildl. Manage. $46(2): 462-468$.

Friend, M., and D.0. Trainer. 1970a. Some effects of sublethal levels of insecticides on vertebrates. J. Wildl. Dis. $6(4): 335-342$.

and 1970b. Polychlorinated biphenyl: interaction with duck hepatitis virus. Science 170:1314-1316.

Fyfe, R.W., J. Campbell, B. Hayson, and K. Hodson. 1969. Regional population declines and organochlorine insecticides in Canadian prairie falcons. Can. Field-Nat. 83(3):191-200.

R.W. Risebrough, and W. Walker, II. 1976a. Pollutant effects on the reproduction of the prairie falcons and merlins of the Canadian prairies. Can. Field-Nat. $90(3): 346-355$.

S.A. Temple, and T.J. Cade. 1976b. The 1975 North American peregrine falcon survey. Can. Field-Nat. 90(3):228273 .

Gannon, N., and J.H. Bigger. 1958. The conversion of aldrin and heptachlor to their epoxides in soil. J. Econ. Ent. $51(1): 1-2$.

- n and G.C. Decker. 1958. The conversion of heptachlor to its epoxide on plants. J. Econ. Ent. 51(1):3-7.

Good, E.E., and G.W. Ware. 1969. Effects of insecticides on reproduction in the laboratory mouse. IV. Endrin and dieldrin. Tox. \& Appl. Pharm. 14:201-203.

Graham, F., Jr. 1970. Since Silent Spring. Fawcett Publications, Inc:, Greenwich, Conn. $288 \mathrm{pp}$. 
Greenberg,R.E., and W.R. Edwards. 1970. Insecticide residue levels in eggs of wild pheasants in Illinois. Trans. Ill. St. Acad. Sci. 63(2):136-147.

Greenwood, R.J., Y.A. Greichus, and E.J.Hugghins. 1967. Insecticide residues in big game mammals of South Dakota. J. Wildl. Manage. 31(2):288-299.

Hansen, L.G., S.B. Dorn, S.M. Sundlof, and R.S. Vogel. 1978. Toxicity, accumulation, and depletion of hexachlorobenzene in laying chickens. J. Agric. Food Chem. 26(6): 1369-1374.

Harmata, A.R. 1982. Behavior and ecology of wintering and migrant bald eagles in the Rocky Mountains. Mont. Dept. Fish, Wildl. \& Parks, Proj. SE-1, Job 1. 114 pp. (litho).

Harris, C.R., H.J.Svec, and R.A. Chapman. 1978. Potential of pyrethroid insecticides for cutworm control. J. Econ. Ent. $71: 692-696$.

Harris, V.T., and P.H. Eschmeyer. 1976. Sport fishery and wildife research, 1974-75. U.S. Fish \& Wildl. Serv. Rept.

Hathway, D.E., and E.C.Amoroso. 1972. The effects of pesticides on mammalian reproduction. Pp. 218-251 In Toxicology, biodegradation and efficacy of livestock pesticides. M.A. Khan and W.O. Haufe, Eds., Swets \& Zeitlinger, Amsterdam. 433 $\mathrm{pp}$.

Hazletine, S.D., and R.M. Prouty. 1980. Aroclor 1242 and reproductive success of adult mallards (Anas platyrhynchos). Env. Res. 23:29-34.

Heath, R.G., and S.A.Hill. 1974. Nationwide organochlorine and mercury residues in wings of adult mallards and black ducks during the 1969-70 hunting season. Pest. Monit. J. $7(3 / 4): 153-164$.

J.W. Spann, J.F. Kreitzer, and C. Vance.1972a. Effects of polychlorinated biphenyis on birds. Proc. Int. Ornith. Cong. 15:475-485.

E.F.Hill, and J.F.Kreitzer. 1972b. Comparative dietary toxicities of pesticides to birds. U.S. Dept. Int., Fish \& Wildl. Serv., Spec. Sci. Rept.--Wildl. No. 152. 57 pp.

Heinz, G.H., and R.W. Johnson. 1981. Diagnostic brain residues of dieldrin: some new insights. Pp. 72-92 In Avian and mammalian wildlife toxicology: second conference. E.E. Kenaga and D.W. Lamb, Eds., ASTM STP 757. 164 pp.

E.F. Hill, and J.F. Contrera. 1980. Dopamine and norepinephrine in ring doves fed DDE, dieldrin, and Aroclor 1254. Tox. Appl. Pharm. 53:75-82. 
Henny, C.J., J.R. Bean, and R.W. Fyfe. 1976. Elevated heptachlor epoxide and DDE residues in a merlin that died after migrating. Can. Field-Nat. 90(3):361-363.

L.J. Blus, and C.J. Stafford. In Press. Effects of heptachlor on American kestrels in the Columbia Basin, Oregon. J.Wildl. Manage.

Hepworth, W.G., and G. Roby. 1968. Wildlife and livestock losses in Crook County associated with endrin spraying to control army worms on winter wheat. Wyo. Game and Fish Comm., Game \& Fish Res. Lab. 5 pp.

Hickey, J.J., Ed. 1969. Peregrine falcon populations, their biology and decline. Univ. Wisc. Press, Madison. 596 pp.

Hill, E.F. 1972. Avoidance of lethal dietary concentrations of insecticides by house sparrows. J. Wildl. Manage. $36(2): 635-639$.

W.E. Dale, and J.W. Miles. 1971. DDT intoxication in birds: subchronic effects and brain residues. Tox. Appl. Pharm. 20:502-514.

R.G. Heath, and J.D. Williams. 1976. Effects of dieldrin and Aroclor 1242 on Japanese quail eggshell thickness. Bull. Env. Contam. Tox. 16(4):445-453.

and W.J. Fleming. 1982. Anticholinesterase poisoning in birds: field monitoring and diagnosis of acute poisoning. Env. Tox. Chem. 1:27-38.

Hinshaw, L.B., L.A. Solomon, D.A. Reins, V. Fiorica, and T.E. Emerson. 1966. Effects of the insecticide endrin on the cardiovascular system of the dog. J. Pharm. Exp. Therap. $153(2): 225-236$.

Horwitz, W., A. Senzel, and H. Reynolds (eds.). 1975. Official methods of analysis of the Association of Official Analytical Chemists. AOAC, Washington, D.C. 1094 pp.

Hotchkiss, N., and R.H. Pough. 1946. Effect on forest birds of DDT used for gypsy moth control in Pennsylvania. J. Wildl. Manage. 10(3):202-207.

Hunt, E.G., and A.I. Bishoff. 1960. Inimical effects on wildlife of periodic DDD applications to Clear Lake. Calif. Fish \& Game. 46(1):91-106.

and J.D. Keith. 1962. Pesticide-wildlife investigations in California, 1962. Univ. Calif. Program. The use of agricultural chemicals in California, a summary of the problems and progress in solving them. 29 pp. 
James, D., and K.B. Davis, Jr. 1965. The effects of sublethal amounts of DDT on the discrimination ability of the bobwhite, Colinus virginianus (Linnaeus). Am. Zool. 5(2):229 (abstract).

Janda, J. 1959. On the nutrition of young partridges, Perdix perdix L. Zool. Listy 22(4):377-383.

Jarvinen, A.W., and R.M. Tyo. 1978. Toxicity to fathead minnows of endrin in food and water. Arch. Env. Contam. Tox. 7:409.

Johnson, L.G., R.L. Morris, and H. Harrison. 1970. Preliminary study of pesticide levels in the eggs of Iowa pheasants, bluewing teal and coots. Bull. Env. Contam. Tox. 5(5):474478.

Johnson, R.E., T.C. Carver, and E.H. Dustman. 1967. Indicator species near top of food chain chosen for assessment of pesticide base levels in fish and wildlife--clams, oysters, and sediment in estuarine environment. Pest. Monit. J. $1(1): 7-13$.

Johnson, W.W., and M.T. Finley. 1980. Handbook of acute toxicity of chemicals to fish and aquatic invertebrates. U.S. Dept. Int., Fish \& Wildl. Serv., Pub. 137. 98 pp.

Jonas, R. 1966. Merriam's turkeys in southeastern Montana. Mont. Fish \& Game Dept., Tech. Bull. No. 3. 36 pp.

Kaiser, T.E., W.L. Reichel, L.N. Locke, E. Cromartie, A.J. Krynitsky, T.G. Lamont, B.M. Mulhern, R.M. Prouty, C.J. Stafford, and D.M. Swineford. 1980. Organochlorine pesticide, $P C B$, and $P B B$ residues and necropsy data for bald eagles from 29 states--1975-77. Pest. Monit. J. 13(4):145149 .

Katz, M., and G.G. Chadwick. 1961. Toxicity of endrin to some Pacific Northwest fishes. Trans. Amer. Fish. Soc. 90:394.

Keith, J.0. 1963. Wildlife hazards of endrin used as a rodenticide in alfalfa. Pp. 51-52 In Pesticide-Wildlife Studies: A review of Fish and Wildife Service Investigations during 1961 and 1962. U.S. Dept. Int., Fish \& Wildl. Serv., Circ. 167. 109 pp.

1966. Insecticide contaminations in wetland habitats and their effects on fish-eating birds. J. Appl. Ecol. 3 (suppl.):71-85.

Korte, F. 1972. Biochemistry and structure of organochlorine pesticides. Pp. 1-22 In Toxicology, biodegradation and efficacy of livestock pesticides. M.A. Khan and W.O. Haufe, Eds., Swets \& Zeitlinger, Amsterdam. 433 pp. 
Kreitzer, J.F. 1972. The effect of embryonic development on the thickness of the eggshells of Coturnix quail. Poultry Sci. 51: $1764-1765$.

1980. Effects of toxaphene and endrin at very low dietary concentrations on discrimination acquisition and reversal in bobwhite quail, Colinus virginianus. Env. Poll. (Series A) 23:217-230.

, and J.W. Spann. 1968. Mortality among bobwhites confined to a heptachlor contaminated environment. J. Wildl. Manage. $32(4): 874-878$.

Linder, R.L., and R.B. Dahlgren. 1970. Occurrence of organochlorine insecticides in pheasants of South Dakota. Pest. Monit. J. 3(4):227-232.

Lorang, K.D. 1979. Waterfowl and hunter use of Freezout Lake Game Management Area, Teton County, Montana. M.S. Thesis, Mont. St. Univ., Bozeman. 79 pp.

Ludke, J.L., E.F.Hill, and M.P. Dieter. 1975. Cholinesterase (ChE) response and related mortality among birds fed ChE inhibitors. Arch. Env. Contam. Tox. 3:1-21.

Macek, K.J., C. Hutchinson, and O.B. Cope. 1969. The effects of temperature on the susceptibility of bluegills and rainbow trout to selected pesticides. Bull. Env. Contam. Tox. $4(3): 174-183$.

Marshall, E. 1982. EPA's high-risk carcinogen policy. Science, 218: $975-978$.

Martin, W.E. 1969. Organochlorine insecticide residues in starlings. Pest. Monit. J. 3(2):102-114.

and P.R. Nickerson. 1972. Organochlorine residues in starlings--1970. Pest. Monit. J. 6(1):33-40.

McDonald, S. 1979. Evaluation of insecticides for control of the army cutworm. J. Econ. Ent. 72:277-280.

1981. Evaluation of organophosphorous and pyrethroid insecticides for control of the pale western cutworm. J. Econ. Ent. 74:45-48.

McEwen, L.C., and R.L. Brown. 1966. Acute toxicity of dieldrin and malathion to wild sharp-tailed grouse. J. Wildl. Manage. $30(3): 604-611$.

E.G.D. Blomberg, and C.E. Knittle. 1972. Effects of endrin on wildlife in western wheatland. Proc. $23 \mathrm{rd}$. Ann. Mtg. Amer. Inst. Biol. Sci., Univ. Minn. (Abstract). 
McLane, M.A.R., and D.L. Hughes. 1980. Reproductive success of screech owls fed Aroclor 1248. Arch. Env. Contam. Tox. 9:661-665.

Mestitzova, M. 1967. On reproduction studies and the occurrence of cataracts in rats after long-term feeding of the insecticide heptachlor. Experientia 23(1):42-43.

Menzie, C.M. 1974. Metabolism of pesticides: an update. U.S. Dept. Int., Fish and Wild. Serv., Spec. Sci. Rept.--Wildl. No. 184. $486 \mathrm{pp}$.

Mikol, S.A. 1980. Field guidelines for using transects to sample nongame bird populations. U.S. Fish \& Wildl. Serv., Biol. Serv. Program, FWS/OBS-80/58. 26 pp.

Montana Cooperative Extension Service. 1975. Materials for insect control in Montana. 1975. Mont. St. Univ., Bull. 1109 (Rev•). 54 pp.

Montana Crop and Livestock Reporting Service. 1982. Montana agricultural statistics. 1982. Compiled by Mont. Crop and Livestock Rept. Serv., Helena 19:1-81.

Montana Department of Agriculture. 1981. Chemical alternatives to endrin for control of army cutworms and pale western cutworms attacking small grains in Montana. Dept. Rept., December. $11 \mathrm{ppm}$. (mimeo.).

Department of Health and Environmental Sciences, and Department of Livestock. Undated. The 1979 polychlorinated biphenyl contamination incident at Billings, Montana: the State of Montana's position report. Helena. $34 \mathrm{pp}$.

Montana Insect Pests, 1953-1954. 1954. Thirty-fifth report of the State Entomologist. Mont. St. Coll., Agric. Expt. Sta., Bull. 504.27 pp.

Moore, G.L., Y.A. Greichus, and E.J. Hugghins. 1968. Insecticide residues in pronghorn antelope of South Dakota. Bull. Env. Contam. Tox. 3(5):269-273.

Morris, R.D. 1968. Effects of endrin feeding on survival and reproduction in the deer mouse, Peromyscus maniculatus. Can.J. Zool. 46(5):951-958.

- 1970. The effects of endrin on Microtus and Peromyscus. I. Unenclosed field populations. Can. J. Zool. 48(4):695-708.

Mount, D.I., and G.J. Putnicki. 1966. Summary report of the 1963 Mississippi fish kill. Trans. N. Amer. Wildl. \& Nat. Res. Conf. 31:177-184. 
Mulhern, B.M., W.L. Reichel, L.N. Locke, T.G. Lamont, A. Belisle, E. Cromartie, G.E. Bagley, and R.M. Prouty. 1970. Organochlorine residues and autopsy data from bald eagles, 1966-68. Pest. Monit. J. 4(3): 141-144.

Musseh1, T., J. Gaffney, and D.Flath. 1978. A strategic plan for Montana's wildlife and fisheries programs, 1977-1999. Pp. 1-208 In 1978 Montana statewide comprehensive outdoor recreation plan. Mont. Dept. Fish and Game, Helena. 318 $\mathrm{pp}$.

Nash, R.G., and E.A. Woolson. 1967. Persistence of chlorinated hydrocarbon insecticides in soil. Science 157(3791):924-927.

Nelson, R.W. 1976. Behavioral aspects of egg breakage in peregrine falcons. Can. Field-Nat. 90(3):320-329.

Newton, I. 1976. Raptor research and conservation during the last five years. Can. Field-Nat. 90(3):225-227.

Nickerson, P.R., and K.R. Barbehenn. 1975. Organochlorine residues in starlings, 1972. Pest. Monit. J. 8(4):247-254.

Ohlendorf, H.M., D.M. Swineford, and L.N. Locke. 1979. Organochlorine poisoning of herons. Pp. 176-185 In Proceedings 1979 Conference of the Colonial Waterbird Group. W.E. Southern, Compiler, Lab. of Ornith., Cornell Univ., Ithaca, New York. 260 pp.

Oka, I.N., and D. Pimentel. 1974. Corn susceptibility to corn leaf aphids and common corn smut after herbicide treatment. Env. Ent. 3:911-915.

Ottolenghi, A.D., J.K. Haseman, and F. Suggs. 1973. Teratogenic effects of aldrin, dieldrin, and endrin in hamsters and mice. Teratology 9:11-16.

Peakall, D.B. 1976. The peregrine falcon (Falco peregrinus) and pesticides. Can. Field-Nat. 90(3):301-307.

-...., and M.L. Peakall. 1973. Effect of polychlorinated biphenyl on the reproduction of artificially and naturally incubated dove eggs. J.Appl. Ecol. 10:863-868.

-..., T.J. Cade, C.M. White, and J.R. Haugh. 1975. Organochlorine residues in Alaska peregrines. Pest. Monit. J. $8(4): 255-260$.

Phillips, C. 1981. 1980 hunting and fishing expenditure estimates in Wyoming. Wyo. Game \& Fish Dept. Rept. 44 pp. (litho.). 
Pimentel, D. 1971. Ecological effects of pesticides on nontarget species. Exec. Off. of the President, Office of Science and Technology. $220 \mathrm{pp}$.

and C.A. Edwards. 1982. Pesticides and ecosystems. Bioscience $32(7): 595-600$.

Platanow, N.S., and L.H. Karstad. 1973. Dietary effects of polychlorinated biphenyls in mink. Can. J. Comp. Med. $37: 391-400$.

Porter, R.D., and S.N. Wiemeyer. 1972. DDE at low dietary levels kills captive American kestrels. Bull. Env. Contam. Tox. 8(4): 193-199.

Post, G., and T.R. Schroeder. 1971. Toxicity of four insecticides to four salmonid species. Bull. Env. Contam. Tox. 6:144-147.

Potts, G.R. 1970. Recent changes in the farmland fauna with special reference to the decline of grey partridge. Bird Study $17(2): 145-166$.

President's Science Advisory Committee. 1963. Use of Pesticides. The White House, Wash., D.C. 25 pp.

Prouty, R.M., W.L. Reichel, L.N. Locke, A.A. Belisle, E. Cromartie, T.E. Kaiser, T.G. Lamont, B.M. Mulhern, and D.M. Swineford. 1977. Residues of organochlorine pesticides and polychlorinated biphenyls and autopsy data for bald eagles, 1973-74. Pest. Monit.J. 11(3):134-137.

Radeleff, R.D. 1964. Veterinary toxicology. Lea and Febiger, Philadelphia, Pa. $314 \mathrm{pp}$.

Reichel, W.L., E. Cromartie, T.G. Lamont, B.M. Mulhern, and R.M. Prouty. 1969. Pesticide residues in eagles. Pest. Monit. J. $3(3): 142-144$.

L.N. Locke, and R.M. Prouty. 1974. Case report-peregrine falcon suspected of pesticide poisoning. Avian Dis. $18(3): 487-489$.

Reuber, M.D. 1979. Carcinogenicity of endrin. Sci. Total Env. 12:101-135.

Revzin, A.M. 1966. Effects of endrin on telencephalic function in the pigeon. Tox. \& Appl. Pharm. 9(1):75-83.

Reynolds, L.M. 1969. Polychlorobiphenyls (PCB's) and their interference with pesticide residue analysis. Bull. Env. Contam. Tox. 4(3):128-143. 
Ridsdale, R., and P. Granett. 1969. Responses of caged grackles to chemically treated and untreated foods. J. Wild . Manage. 33(3):678-681.

Ritchey, S.J., R.W. Young, and E.O. Essary. 1972. Effects of heating and cooking method on chlorinated hydrocarbon residues in chicken tissues. J. Agric. Food Chem. $20(2): 291-293$.

Rosene, W., Jr. 1965. Effects of field applications of heptachlor on bobwhite quail and other wild animals. J. Wildl. Manage. 29(3):554-580.

...., P. Stewart, and V. Adomatis. 1961. Residues of heptachlor epoxide in wild animals. Proc. SE Assoc. Game \& Fish Comm. 15:107-113.

and D.W. Lay. 1963. Disappearance and visibility of quail remains. J.Wildl. Manage. 27(1):139-142.

Rowe, D.R., L.W. Canter, P.J. Snyder, and J.W. Mason. 1971. Dieldrin and endrin concentrations in a Louisiana estuary. Pest. Monit. J. 4(4):177-183.

Rudd, R.L. 1964. Pesticides and the living landscape. Univ. of Wisc. Press, Madison, Wis. 320 pp.

and R.E. Genelly. 1956. Pesticides: their use and toxicity in relation to wildlife. Calif. Dept. Fish \& Game, Game Bull. No. 7. 209 pp.

Rundquist, V.M. 1973. Avian ecology on stock ponds in two vegetational types in north-central Montana. Ph.D. Thesis, Mont. St. Univ., Bozeman. $116 \mathrm{pp}$.

Rush, G.F., J.H. Smith, K. Maita, M. Bleavins, R.J. Aulerich, R.K. Ringer, and J.B. Hook. 1983. Perinatal hexachlorobenzene toxicity in the mink. Env. Res. 31:116-124.

Sauter, E.A., and E.E. Steele. 1972. The effects of low level pesticide feeding on the fertility and hatchability of chicken eggs. Poultry Sci. 51(1):71-76.

Savage, E.P. 1971. The current status of polychlorinated biphenyls. Presented at Mont. St. Pesticides Workshop, Helena, Mont. 28-30 Sept. 13 pp. (litho.).

Schneider, F. 1965. Some pesticide-wildlife problems in Switzerland. J.Appl. Ecol. 3 (suppl.): 15-20.

Seidensticker, J.C., IV, and H.V. Reynolds, III. 1971. The nesting, reproductive performance, and chlorinated hydrocarbon residues in the red-tailed hawk and great horned owl in south-central Montana. Wilson Bull. 83(4):408-418. 
Sherman, R.W. 1977. The current status of DDT in the United States. Pp. 541-545 In Pesticide management and insecticide resistance. D.L. Watson and A.W.A. Brown, Eds., Academic Press, New York. $638 \mathrm{pp}$.

Skaar, P.D. 1980. Montana bird distribution. Second Ed. P.D. Skaar, Bozeman, Mt. $66 \mathrm{pp}$.

Smith, C. 1982. Waterfowl breeding population survey for Montana. U.S. Fish \& Wildl. Serv. 4 pp.+11 pp. of tables.

Stadelman, W.J., B.J. Liska, B.E. Langlois, G.C. Mostert, and A.R. Stemp. 1965. Persistence of chlorinated hydrocarbon insecticide residues in chicken tissues and eggs. Poultry Sci. $44(2): 435-437$.

Steel, R.G.D., and J.H. Torrie. 1980. Principles and procedures of statistics (second ed.). McGraw-Hill Book Company, N.Y. 603 pp.

Stende11, R.C. 1976. Summary of recent information regarding effects of PCB's on birds and mammals. Pp. 262-267 In Proc. Natl. Conf. on Polychlorinated Biphenyls. Chicago, Ill., Rept. No. EPA-560/6-75-004.

Stickel, L.F. 1973. Pesticide residues in birds and mammals. Pp. 254-312 In Environmental pollution by pesticides. C.A. Edwards, Ed., Plenum Press, London. 542 pp.

, and L.I. Rhodes. 1970. The thin eggshell problem. Pp. 31-35 In The biological impact of pesticides in the environment. J.W. Gillett, Ed., Env. Health Sci. Ser. No. 1.210 pp.

W.H. Stickel, R.D. McArthur, and D.L. Hughes. 1979 b. Chlordane in birds: a study of lethal residues and Ioss rates. Pp. 387-396 In Toxicology and occupational medicine. W.B. Deichmann, Organizer, Elsevier/North Holland, N.Y.

Stickel, W.H. 1965. Delayed mortality of DDT-dosed cowbirds in relation to disturbance. P. 17 In Effects of pesticides on fish and wildiife. U.S. Fish \& Wildl. Serv., Circ. 226. 77 $\mathrm{pp}$.

D.W. Hayne, and L.F. Stickel. 1965. Effects of heptachlor-contaminated earthworms on woodcocks. J. Wildl. Manage. 29(1):132-146.

J.A. Galyen, R.A. Dyrland, and D.L. Hughes. 1973. Toxicity and persistence of mirex in birds. Pp. 437-467 In Pesticides and the environment: a continuing controversy. Int.-Am. Conf. Tox. \& Occup. Med., W.B. Deichmann, Ed., Intercontinental Medical Book Corp., N.Y. 
W.L. Reichel, and D.L. Hughes. 1979a. Endrin in birds: lethal residues and secondary poisoning. Pp. 396-406 In Toxicology and Occupational Medicine. W.B. Deichmann, Organizer, Elsevier/Holland, N.Y.

Stromborg, K.L. 1977. Seed treatment pesticide effects on pheasant reproduction at sublethal doses. J. Wildl. Manage. $41(4): 632-642$.

Terriere, L.C., G.H. Arscott, and U. Kiigemagi. 1959. The endrin content of eggs and body tissue of poultry receiving endrin in their daily diet. J.Agric. Food Chem.7(7):502504 .

Train, R.E. 1975. Registrations of pesticides containing heptachlor or chlordane. Intent to suspend; Findings of imminent hazard. Fed. Reg . 40(159):34456-34459.

Tucker, R.K., and D.G. Crabtree. 1970. Handbook of Toxicity of pesticides to wildlife (Rev.). Bur. Sp. Fish. \& Wildl., Denver Wildl. Res. Cent., Resource Publ. No. 84. $131 \mathrm{pp}$.

Turtle, E.E., A. Taylor, E.N. Wright, R.J.P. Thearle, H. Egan, W.H. Evans, and N.M. Soutar. 1963. The effects on birds of certain chlorinated insecticides used as seed dressings. J. Sci. Food Agric. 14:567-577.

U.S. Department of Health, Education and Welfare, Food and Drug Administration. 1972. Pesticides analytical manual. Vol. 1. Section 212.13a.

U.S. Fish and Wild Ife Service. 1981. Status of waterfowl and fall flight forecast. $23 \mathrm{pp}$.

Vanderstoep, J., and J.F. Richards. 1971. The changes in egg shell strength during incubation. Poultry Sci. 49:276-285.

Van Velzen, A.C., W.B. Stiles, and L.F. Stickel. 1972. Lethal mobilization of DDT by cowbirds. J. Wildl. Manage. $36(3): 733-739$.

Vermeer, K., and L.M. Reynolds. 1970. Organochlorine residues in aquatic birds in the Canadian Prairie Provinces. Can. Field-Nat. $84(2): 117-130$.

Wallestad, R. 1975. Life history and habitat requirements of sage grouse in central Montana. Mont. Dept. Fish and Game, Game Manage. Div. and U.S. Dept. Int., Bur. Land. Manage. $65 \mathrm{pp}$.

Wallmo, O.C. Ed. 1981. Mule and black-tailed deer of North America. A Wildl. Manage. Inst. Book, Univ. Nebraska Press, Lincoln. $605 \mathrm{pp}$. 
Weigand, J.P. 1980. Ecology of the Hungarian partridge in northcentral Montana. Wildl. Monogr. No. 74. $106 \mathrm{pp}$.

_..., and R.G. Janson. 1976. Montana's ring-necked pheasant: history, ecology and management. Mont. Dept. Fish \& Game, Game Manage. Div. $178 \mathrm{pp}$.

White, D.H. 1976. Nationwide residues of organochlorines in starlings, 1974. Pest. Monit. J. 10(1):10-17.

1979a. Nationwide residues of organochlorine compounds in starlings (Sturnus vulgaris), 1976. Pest. Monit. J. $12(4): 193-197$.

1979b. Nationwide residues of organochlorine compounds in wings of adult mallards and black ducks, 1976-77. Pest. Monit. J. 13(1):12-16.

- and R.G. Heath. 1976. Nationwide residues of organochlorines in wings of adult mallards and black ducks, 197273. Pest. Monit. J. $9(4): 176-185$.

White, G.C., D.R. Anderson, K.P. Burnham, and D.L. Otis. 1982. Capture-recapture and removal methods for sampling closed populations. Los Alamos Natl. Lab., Publ. LA-8787-NERP. $235 \mathrm{pp}$.

Yang, R.S.H., K.A. Pittman, D.R. Rourke, and V.B. Stein. 1978. Pharmacokinetics and metabolism of hexachlorobenzene in the rat and the Rhesus monkey. J. Agric. Food Chem. 26(5):10761083.

Yde, C.A. 1977. Distribution and movements of sharp-tailed grouse during spring and summer in relation to rest-rotation grazing. M.S. Thesis, Mont. St. Univ., Bozeman. 70 pp. 
APPENDIX 



\section{APPENDIX A}

\section{Chemical nomenclature of chlorinated hydrocarbon compounds detected in Montana wildlife tissues.}

\begin{tabular}{|c|c|}
\hline Common Name & Chemical Name \\
\hline Alpha-chlordane & $\begin{array}{l}\text { 1-exo, 2-exo-4, 5, 6, 7,8,8-octachloro-3a, 4,7,7a-tetrahydro-4, } \\
\text { 7-methanoidene }\end{array}$ \\
\hline Beta-nonachlor & $\begin{array}{l}\text { 1-exo, 2-exo, 3-exo-4, 5, 6, 7, 8, 8-nonachloro-2, 3, 2a, 4, 7, 7a-hexatiydro- } 4 \text {, } \\
7 \text {-methanoindene }\end{array}$ \\
\hline $\mathrm{BHC}$ & $1,2,3,4,5,6$-hexachlorocyclohexane \\
\hline DDD & 1,1-dichloro-2,2-bis ( $p$-chlorophenyl)ethane \\
\hline DDE & 1,1 -dichloro-2,2-b1s (p-chlorophenyl)ethylene \\
\hline DDT & $1,1,1$-trichloro-2,2-bis ( $p$-chloropheny 1$)$ et hane \\
\hline Dieldrin & $\begin{array}{l}1,2,3,4,10,10 \text {-hexachloro-exo- } 6,7 \text {-epoxy-1,4,4a, 5, 6, 7, 8, 8a-octahydro-1, } \\
\text { 4-endo,exo-5,8-dimethanonapthalene }\end{array}$ \\
\hline Endrin & $\begin{array}{l}1,2,3,4,10,10-\text { hexachloro- } 5,7 \text {-epoxy-1,4,4a, } 5,6,7,8,8 \text { a-octahydro- } 1 \\
\text { 4-endo, endo-5,8-dimethanonapthalene }\end{array}$ \\
\hline Gamma-chlordan & $\begin{array}{l}1-e x o, 2-e n d o-4,5,6,7,8,8-o c t a c h 10 \text { ro- } 3 a, 4,7,7 a-t e t \text { ranydro- }, 7 \text {. } \\
\text { methanoidene }\end{array}$ \\
\hline $\mathrm{HCB}$ & Hexachlorobenzene \\
\hline Heptachlor & 1 -exo-4, 5, 6,7,8,8-heptachloro-3a, 4, 7, 7a-tetrahydro-4, 7 -mechanuident \\
\hline Heptachlor epoxide & $\begin{array}{l}\text { 1-exo-4,5, } 6,7,8,8 \text {-heptachloro-2,3-endo-epoxy-3a, 4, 7, } 7 \text { a-tetrahylro-4, } \\
\text { 7-tnethanoldane }\end{array}$ \\
\hline 12-ketoendrin & 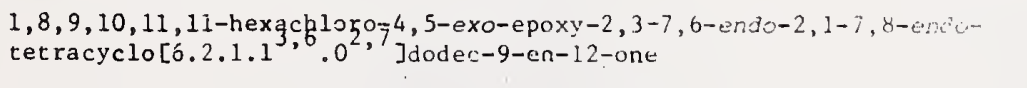 \\
\hline Lindane & Comprised of not less than $99.5 \%$ of the gamma isomer of BHC \\
\hline Mirex & $\begin{array}{l}1,1 a, 2,2,3,3 a, 4,5,5,5 a, 5 b, 6 \text {-dodecachlorodtahydro-1, }, 4-\text { netheme-in- } \\
\text { cyclobuta[cd]-pentelene }\end{array}$ \\
\hline Oxychlordane & $\begin{array}{l}\text { 1-exo, 2-endo-4, } 5,6,7,8,8 \text {-octachloro- } 2,3 \text {-exo-epoxy-2, } 3,3 a, 4,7,7 \mathrm{a}- \\
\text { hexahydro-4, } 7 \text {-me thano indene }\end{array}$ \\
\hline $\begin{array}{l}\text { PCE (Polychlorinated } \\
\text { b1phenyl) }\end{array}$ & $\begin{array}{l}\text { Mixtures of chlorinated biphenyl compounds having various percent- } \\
\text { ages of chlorination }\end{array}$ \\
\hline Toxaphene & $\begin{array}{l}\text { Camphene chlorinated to } 67-69 \% \text { by weight and an average empiricail } \\
\text { formula of } \mathrm{C}_{10} \mathrm{H}_{10} \mathrm{Cl}_{8}\end{array}$ \\
\hline Trans-nonachlor & $\begin{array}{l}\text { 1-exo, 2-endo, 3-exo-4, 5, 6, 7, 8, 8-nonachloro- } 2,3,2 \mathrm{a}, 4,7,7 \text { a-hexahydro-4, } \\
7 \text {-methanolndene }\end{array}$ \\
\hline
\end{tabular}




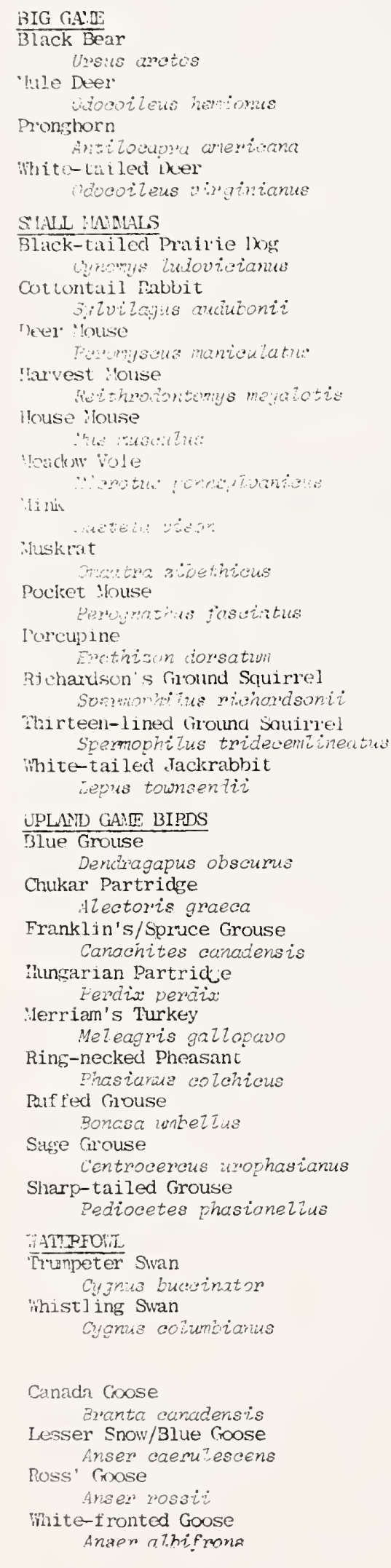

White-fronted Conse
Anser. At.

\section{HATERFOHL COITIULID}

Baldpate/ifigeon

rins anevicare

Bluc-winged "ie:t] Arits disicors

Cinnaron Teal

Anas cyanortise?
Cractwall

$$
\text { Arate etreticra }
$$

Cireen-winged Tcut

viallard

$$
\text { Anas carolineme is }
$$

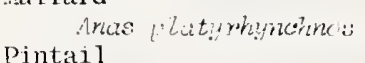

Pintail

Shoveler

Ahas chareat to?

Tora Dnick

$$
\text { Ais: Brotsin }
$$

Vuldican Coldeneye

$$
\text { Buceraba clamiaza }
$$

Bar roy's coldeneye

Bucerha ia landica

Bufllehead

Bucepinzla albeola

Canvasback Authur valisineria

Comon ? lerganser Uergus merganser

Harlecuin Duck

Histrionicus histrionicht:

Itooded :ierganser

idergus cucullatus

Lesser Scaup

$$
\text { Aythya } x_{j} \text { finis }
$$

fied-breasted ilerganser

Redhead Meraus serrator

Asthisa americana

Ring-necked Duck Aythya colzaris

Suddly Duck Oxizura janaicensis

OTFER MOIACIC BIRDS ANT YICPATONY GA'E BIRDS

\section{Conmon Loon \\ Coot Sa? ia inuner}

Faral cirebe

Killaeer

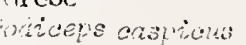

iharndrius vociferase

ilourning Dove

zenaidun maerowa

Spotted Sanclyiper Aetitis macularia

lihite Delican

$$
\text { pelecunus omitiromhyninos: }
$$

Wilson's Snipe

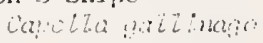

\section{RAPTOIS}

Burrowing Ovi

$$
\text { Sproty to micularial }
$$

(i) Iden raste

Aanith irovaed

Creat fiorned Ovl

$$
\text { sube virginicriss }
$$

Harrier

$$
\text { cirous cintus }
$$

Kestrel

$$
\text { Faleo arroverus }
$$

Lon-eared $\mathrm{at}$

$$
\text { isio otis }
$$

ifer 1 in

$$
\text { Enleo ritubartibs }
$$

Pratile Falcon

$$
\text { atco nexicarus }
$$

Rex-tailod Hawk nutei inmitionsis

Rourit-lescred Hawk Eitan iciarmis

PLSSRIIN: : OLIER BIPDS

B.atcl-billed laspie - Aa ba bis

Brener's Blackbira

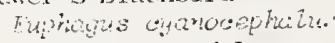

Chexinut-collared Longsipul.

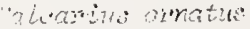

Clift sirallow Fetrichelinor Hyrobunoter Corvbird

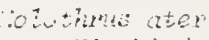

Eustern kingbird incinnlus tyretrine.

Homed Lark stornc chila aipestrois Lapland Longspur "uzan ius Zupponicis

Lorgerhead Shrike Lerrius Luiouic irmu?

McCown's Longspur Bhymophanes "leculs $i=$

Meadowlark stume iza nejlecta

Nountain Plover Eupoda montana

Red-winged Blackbird Age inius phoenticents Rolin ritrates migratorite Snow Bunting

$$
\text { Electrophercax riduid: }
$$

Starling stumine vilgaris

Tree Swallow Iriloproene bi:olur. Vesper Strallow Pooecetes groninew:

White-crowned Sparrow sowtrichia Levizorima

Yellow-rumped Warbler Deraroiáa coronata

\section{ENIDANGERED SPECIES}

Eald Eagle

laliaeetus leusocephal:s

Peregrine Falcon Falco pereiginus

Whooping Crane Grue americana 


\section{APPENDIX C}

Manufacturer's Labels for Endrin 


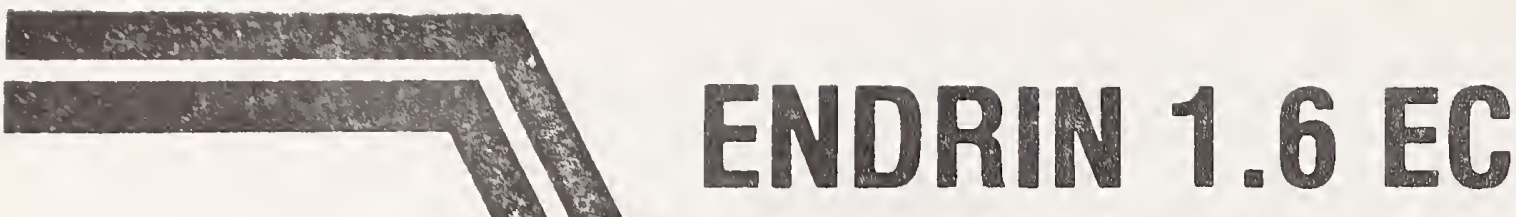

ACTIVE

INGREDIENTS:

- Endrin

Xylene Range Aromatic

Solvent .......... 74.5\%

INERT

INGREDIENTS: $\ldots . .5 .8 \%$

TOTAL $\quad 100.0 \%$

- Hexachloroepoxyoctahydro-endo. endo-dimethanonapthalene

\section{AGRICULTURAL INSECTICIDE}

$19.7 \%$
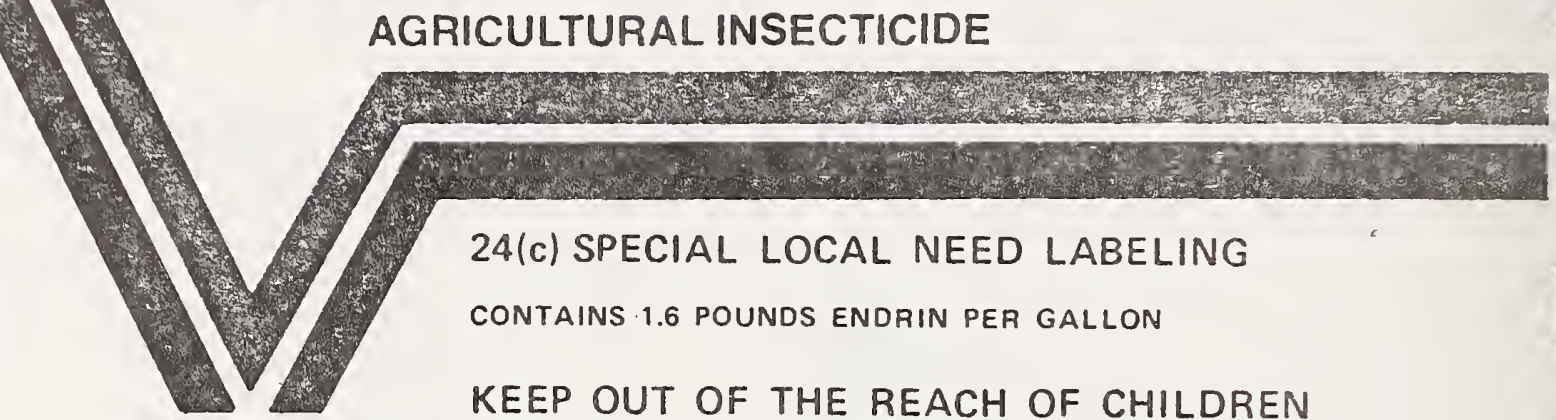

24(c) SPECIAL LOCAL NEED LABELING

CONTAINS 1.6 POUNDS ENDRIN PER GALLON

KEEP OUT OF THE REACH OF CHILDREN

SEE SIDE PANELS FOR STATEMENT OF PRACTICAL

TREATMENT AND ADDITIONAL PRECAUTIONARY STATEMENTS

EPA Reg. 876-153-AA

EPA Est. No. 876--TN-1

PRECAUTIONARY STATEMENTS

Hazards to Humans and Domestic Animals

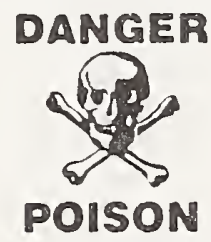

Polsonous if swallowed, inhaled or absorbed through skın. Do not breathe spray mıst. Do not get in eyes, on skın or on clothıng.

STATEMENT OF PRACTICAL TREATMENT

If on skın: Remove by washıng with soap and water. Get medical attention

If in eyes: Flush the eyes with clean water for 10 minutes. Get medical attention.

If inhaled: Remove victım to tresh air. Transport immediately to emergency treatment facility.

If swallowed and victım is conscious and not convulsing: Call a physician ımmediately Give a glass or two of water and induce vomiting by touching back of throat with finger. It is preferable to induce vomiting under medical supervision or to use gastric lavage with a cuffed endotracheal tube because of aspiratıon hazard. Remove victım immediately to emergency !reatment facilities.

If swallowed and victım is unconscious: Clear the upper airway and if victım is not breathing, administer mouth-10-mouth resuscitation. If heart beat is absent, administer cardiac resuscitation. Do not give anyling by mouth. If convulsing, nold head back with jaw forward to keep upper aırway clear. Transport immediately to emergency treatment facilıty, maıntaınıng clear aırway and admınıstering artıficial respiratıon.

\section{INFORMATION FOR PHYSICIANS}

Endrin is a CNS depressant and hepatotoxin. Toxic dosage causes convulsions, respiratory depression, and liver damage. Impaired respiration must be supported by oxygen given by mechanical ventilation. Diazepam is useful in controlling convulsions. Intravenous glucose and $B$ vitarnins help to protect the liver There is no specific antidote. Do not give vegetable oils or milk (which increase Gl absorption). Large amounts of activated charcoal and saline laxatives help to limit GI absorption. Do not give adrenergic agents (myocardial irritability). Excretion of endrin from the body may require days or weeks.

\section{WORK SAFETY RULES}

Wear clean synthetic gloves and a mask or a pesticide respirator fointly approved by the Mining Enforcement and Safety Administration (formerly the U.S. Bureau of Mines) and by the National Institute for Occupational Safety and Health under the provisions of 30 CFA Part II. Wash thoroughly with soap and water after handling and before eating or smokıng. Wear clean clothing daily.

\section{Required Clothing For Female Workers}

Female ground applicators, mixers and loaders and flagpersons must wear long-sleeved shirts and long pants made of a closely woven fabric, and widebrimmed hats. Mixers and loaders must also wear rubber or synthetic rubber boots and aprons.

\section{Warning to Female Workers}

The Uniled States Environmental Protection Agency has deterimined that endrin causes birth defects in laboratory anımals. Exposure to endrın during pregnancy should be avoided. Female workers must be sure to wear all protective clothing and use all protective equipment specified on this label. In case of accidental spills or other unusual exposure, cease work immediately and follow directions for contact with endrin
ENVIHONMENTAL HĀŹĀOS

This pesticide is toxic to fish and wildlife. Birds and othe wildlife in treated areas may be killed. Keep out of lakes ponds, and streams. Do not contamınate water by cleaning of equipment or disposal of wastes. Do not apply where runoff is likely to occur.

This pesticide is toxic to bees exposed to direct applica tion. Application should be timed to coincide with periods of minimum bee activity, usually between late evening and early mornıng.

\section{STORAGE AND DISPOSAL}

\section{PROHIBITIONS}

Do not contaminate water, food or feeo by storage. disposal or the cleaning of equipment. Open dumping is prohıbited

PESTICIDE DISPOSAL

Pesticide, spray mixture or rinsate that cannot be used or chemically reprocessed should be disposed of in a landfill approved for pestıcides or buried in a safe place away from water supplies.

CONTAINER DISPOSAL

For less than 30 gallons: Triple rinse, and offer for recycling, reconditioning, or disposal in approved landfill, or bury in a safe place

For 30 gallons or larger: Reseal contaıner and offer for reconditioning OR triple rinse and offer for recycling. reconditıoning or disposal in an approved landfill, or bury in a safe place.

\section{GENERAL}

Consult Federal, State or Local disposal authorilues for approved alternatıve procedures.

\section{Procedures to Follow If Fish Kills} Occur or If Ponds Are Contaminated

In case of fish kills, fish must be collected promptly and disposed of by burial. Ponds in which fish kills have occurred, and user-owned ponds exposed to endrin by application at distances closer than otherwise pronibited. must be posted with signs statıng: "Contaminated: No Fishing". Signs must remain for one year after a fish kill has occurred or for six months after lesser contamlnatıon unless laboratory analysıs shows endrın resioues in the edible portion of fish to be less than 0.3 parts per million (ppm)

PHYSICAL OR CHEMICAL HAZARDS

Do Not Use, Pour, Spılt, or Store Near Heat or Open Flame. 

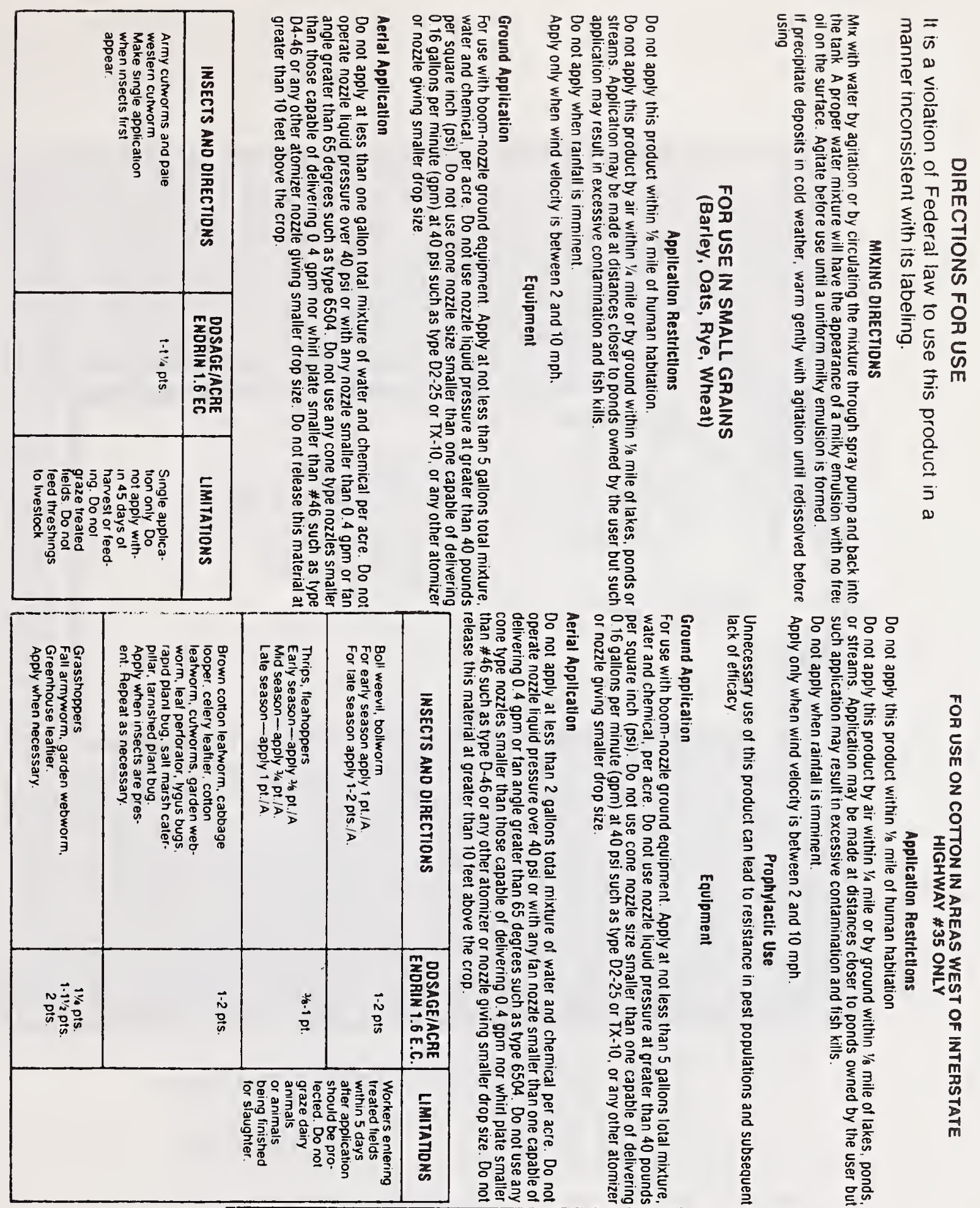

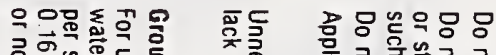

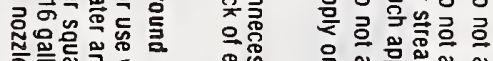

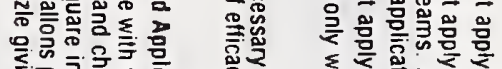

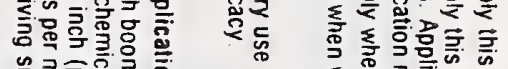

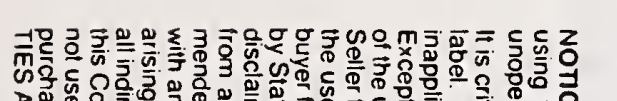

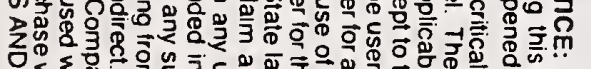

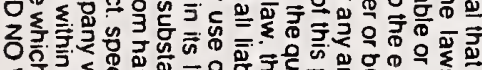

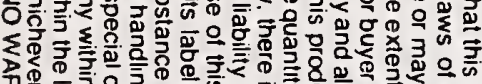

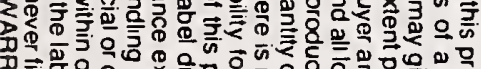

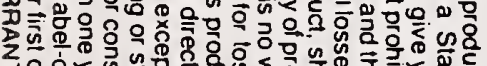

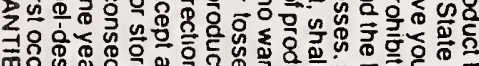

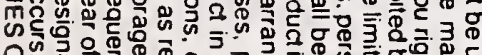
Tं

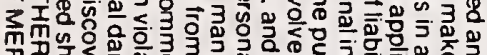

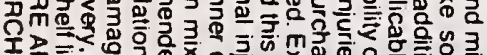

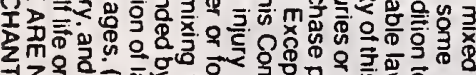

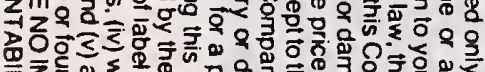

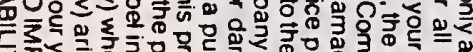

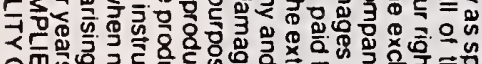

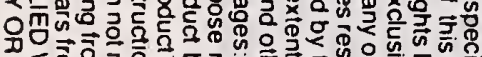

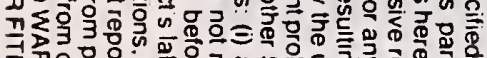

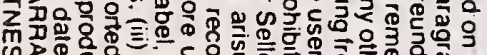

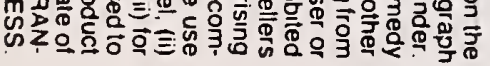

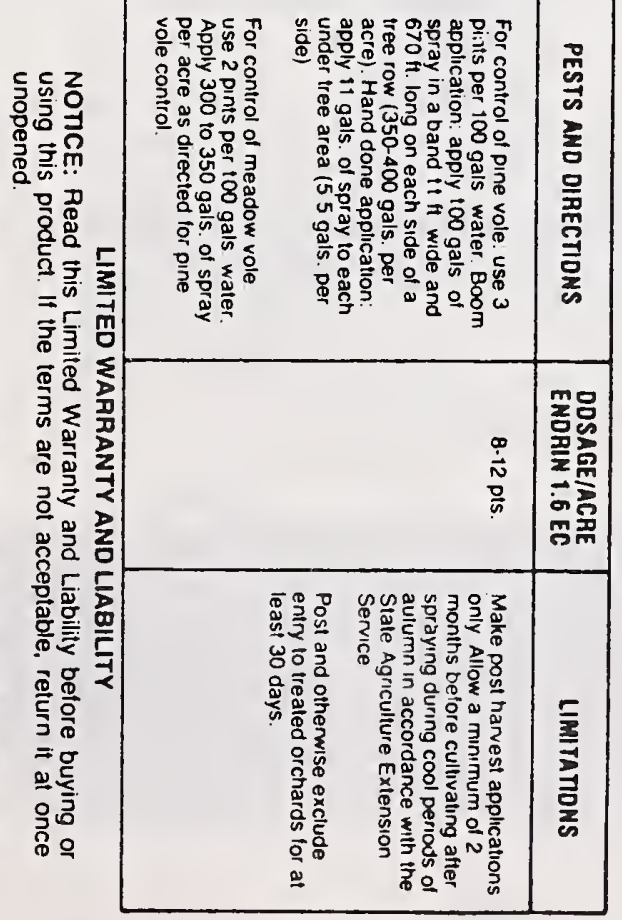

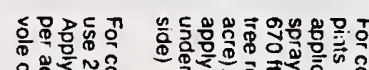

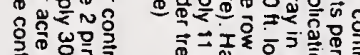

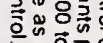

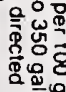

कัตक

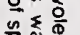

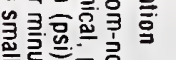

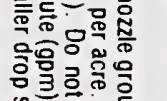
녹

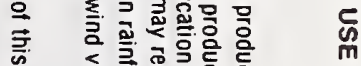

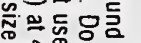

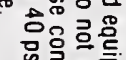

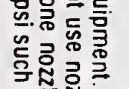

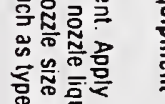

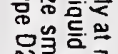
讪产旁总

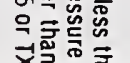
㸚号恕

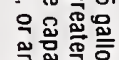

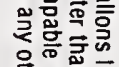

言음

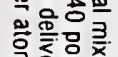

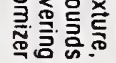

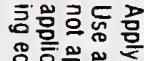

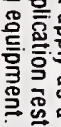

产

言

要这

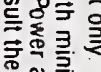

果咢弯

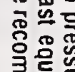

害率票

흘

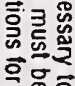

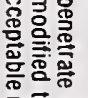

공호을

응ㅎㅇ

훙형.

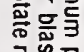

要

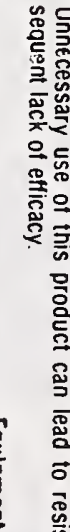

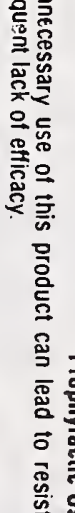

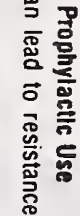

$\overrightarrow{0}$ 要

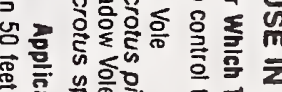

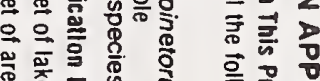

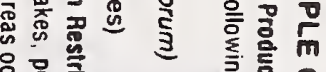

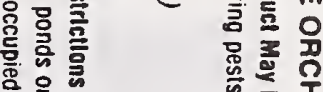

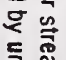

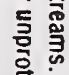

윰

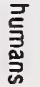

 


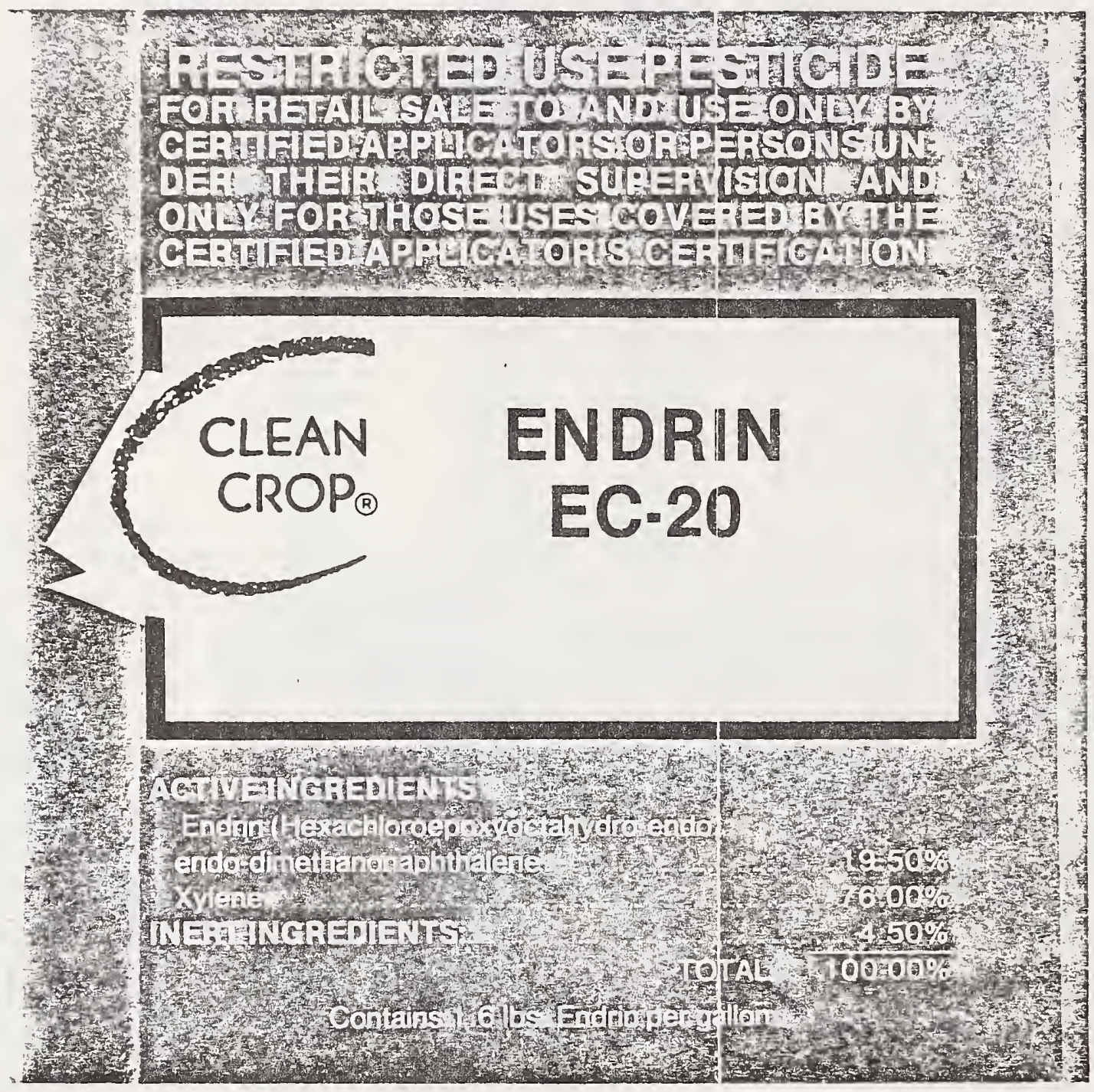

KEEP OUT OF REACH OF CHILDREN DANGER POISON

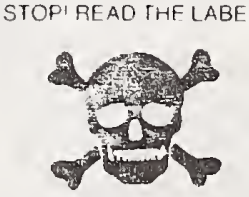

\footnotetext{
CAN KILL YOU
} NOTFOR HOMF USE

See Side Panel for Statement of Practical Treatment and Additional Precautionary Statements

NET CONTENTS U.S. GALLON(S)

EPAREG. NO. 34704-11

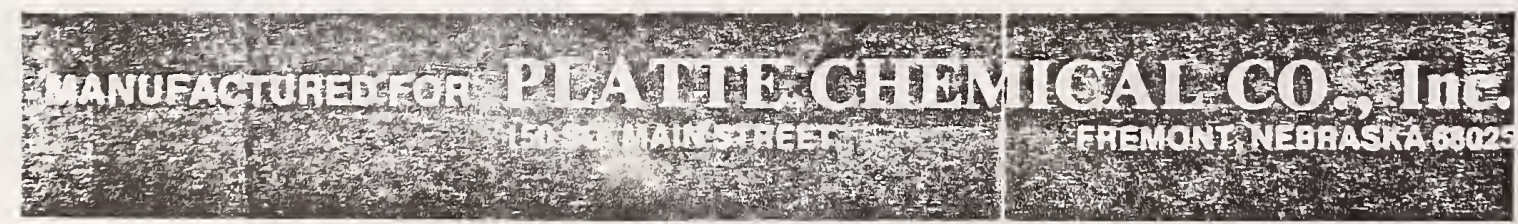




\section{PRECAUTIONARY STATEMENTS HAZARDS TO HUMANS \& DOMESTIC ANIMALS DANGER}

Poisonous by Swallowing, Inhalation, or Skin Contact! Do not get in eyes, on skin, or on clothing. Do not breath vapor or spray mist. Wear clean synthetic rubber gloves and a mask or respirator jointly approved by the Mining Enforcement and Safely Administration (formerly the U.S. Bureau of Mines) and by the National Institute of Occupational Safety and Health under the provisions of 30 CFR Part II. Wash thoroughly with soap and water after handling and before eating or smoking; wear clean clothıng. Do not allow to drift, or apply to areas occupied by unprotected humans or beneficial animals. Do not contaminate feed and foodstuffs.

\section{ENVIRONMENTAL HAZARDS}

This product is toxic to fish and wildife. Keep out of any body of water. Birds feeding on treated areas may be killed.

This pesticide is toxic to bees exposed to direct application. Applications should be timed to coincide with periods of minimum bee activity, usually between late evening and early morning.

Do not apply when weather conditions favor drift from area treated.

Do not contaminate water by cleaning of equipment or disposal of wastes

\section{STATEMENT OF PRACTICAL TREATMENT}

If swailowod and victim is consclous and not convulsing:

Call a physician immediately. Give a glass or two of water and induce vomiting by touching the back of throat with finger. It is preferable to induce vomiting under medical supervision or to use gastric lavage with a cuffed endotracheal tube because of aspiration hazard. Remove victim immediately to emergency treatment facility.

If swallowed and victim is unconscious:

Clear the upper airway and administer mouth-to-mouth resuscitation. If heart beat is absent, administer cardiac resuscitation. Do not give anything by mouth. If convulsing hold head back with jaw forward to keep upper airway clear. Transport immediately to emergency treatment facility, maintaining clear airway and administering artificial respiration.

If Inhaled: Remove victim to fresh air. Apply artificial respiration if indicated Get medical attention immediately.

If on skin: Remove contaminated clothing and wash affected areas thoroughly with soap and water. Get medical attention immediately.

If in eyes: Flush eyes with water for at least 15 minutes. Get medical attention immediately.

In all cases of poisoning medical attention must be obtained immediately or victim may die.

NOTE TO PHYSICIAN: Endrin is a CNS depressant and hepatotoxin. Toxic dosage causes convulsions, respiratory depression, and liver damage. impaired respiration must be supported by oxygen given by mechanical ventilation. Diazepam is useful in controlling convulsions. Intravenous glucose and $\mathrm{B}$ vitamins help to protect the liver. There is no specific antidote. Do not give vegetable oils or milk (which increase Gl absorption). Large amounts of activated charcoal help to limit Gl absorption. Do not give adrenergic agents (myocardial irritability). Excretion of endrin from the body may require days or weeks.

\section{DIRECTIONS FOR USE}

It is a violation of Federal law to use this product in a manner inconsistent with its labeling.

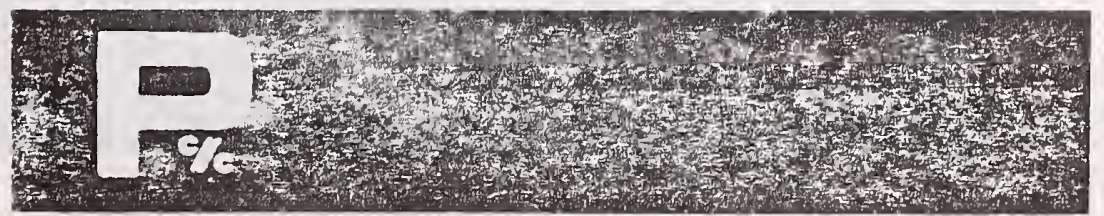




\section{STORAGE AND DISPOSAL}

PROHIBITIONS: Do not contamirrate water, food, or feed by storage or disposal. Open dumping is prohibited.

PESTICIDE DISPOSAL: Pesticide, spray mixture, or rinsate that cannot be used or chemically processed should be disposed of in a landfill. approved for pesticides or buried in a safe place away from water supplies.

CONTAINER DISPOSAL: (a) Reseal container and offer for reconditioning, or (b) Triple rinse (or equivalent) and: offer for recycling, reconditioning, or disposal in approved landfill, or bury in a safe place.

GENERAL: Consult Federal. State or Local Disposal Authorities for approved alternative procedures

STORAGE: Flammable. Keep away from heat or open flame. Keep container closed. Leaking packages should be removed to a safe place. Do not store below $0^{\circ} \mathrm{F}$

\section{REQUIRED CLOTHING FOR FEMALE WORKERS}

Female ground applicators, mixers and loaders and flagpersons must wear long-sleeved shirts and long pants made of a closely woven fabric, and widebrimmed hats. Mixers and loaders must also wear rubber or synthetic rubber boots and aprons.

\section{WARNING TO FEMALE WORKERS}

The United State Environmental Protection Agency has determined that endrin causes birth defects in laboratory animals. Exposure to endrin during pregnancy should be avoided. Female workers must be sure to wear all protective clothing and use all protective equipment specified on this label. In case of accidental spills or other unusual exposure, cease work immediately and follow directions for contact with endrin.

\section{EQUIPMENT}

Ground application. - For use with boom-nozzle ground equipment. Apply at not less than 5 gallons total mixture, water and chemical, per acre. Do not use nozzle liquid pressure at greater than 40 psi (pounds per square inch). Do not use cone nozzle size smaller than 0.16 gallons per minute $(\mathrm{gpm})$ at 40 psi such as type $\mathbf{0 2 - 2 5}$ or TX-10, or any other atomizer or nozzle giving smäller drop size.

Aerial application.- Do not apply at less than one gallon total mixture of water and chemical per acre. Do not operate nozzle smaller than 0.4 gallons per minute $(\mathrm{gpm})$ or fan angle greater than 65 degrees such as type 6504 Do not use any cone type nozzles smaller than $0.4 \mathrm{gpm}$. nor whirl plate smaller than no. 46 such as type $\mathbf{0 4 - 4 6}$ or any other atomizer or nozzle giving smaller drop size. Do not release this material at greater than $10 \mathrm{ft}$. height above the crop.

\section{APPLICATION RESTRICTIONS}

Do not apply this product within $1 / 8$ mile of human habitation

Do not apply this product by air within $1 / 4$ mile or by ground within $1 / 8$ mile of lakes, ponds or streams. Application may be made at distances closer to ponds owned by the user but such application may result in excessive contamination and fish kills.

Do not apply when rainfall is : inminent.

Apply only when wind velocity is between $2 \mathrm{mph}$ and $10 \mathrm{mph}$

\section{PROCEDURES TO BE FOLLOWED IF FISH KILLS OCCUR OR IF PONDS ARE CONTAMINATED}

In case of fish kills, fish must be collected promptly and disposed of by burial Ponds in which fish kills have occurred. and user-owned ponds exposed to endrin by application at distances closer than otherwise prohibited must be posted with signs stating: "Contaminated: No Fishing." Signs must remain for one year after a fish kill has occurred or for six months after lesser contamination unless laboratory analysis shows endrin residues in the edible portions of fish to be less than 0.3 part per million (ppm). 


\section{PESTS FOR WHICH THIS PRODUCT \\ MAY BE APPLIED}

This product may be applied to control the following pests only: army cutworm and pale western cutworm.

\section{DO NOT USE IN UNDILUTED FORM.}

To prepare the spray mixture, $m \in$ asure out the required amount of this material and add it to the proper am, unt of water. Mix thoroughly and apply. agitating continuously. In cold weather this material may deposit a precipitate in the container. Before mixing in this case, the material should be warmed gently and agitated until redissolved. Application should be made at the recommended dosage per acre in sufficient water to provide uniform coverage.

When applying this material by air craft, mix the recommended amounts with sulficient water to provide a minimum for 1 gallon of finished spray per acre. Care should be taken that this material is not allowed to drift onto neighboring crop or non-crop areas.

\section{OBSERYE I NTERVAL BETWEEN LAST APPLICATION AND HARVEST.}

BARLEY, OATS, RYE; WHEAT: Army Cutworms and Pale Western Cutworms-APPLY A SINGLE APPLICATION using 1 to $1 \frac{1}{4}$ pints per acre when insects first appear. DO NOT TREAT WITHIN 45 DAYS OF HARVEST. DO NOT GRAZE LIVESTOCK ON TREATED FORAGE. DO NOT FEED THRESHING TO LIVESTOCK.

\section{DEALERS SHOULD SELLIN ORIGINAL PACKAGES ONLY.}

USAGE CAUTION: DO NOT ALLOW THIS MATERIAL TO DRIFT ONTO NEIGHBORING CROP OR NON-CROP AREAS OR USE IN A MANNER OR AT A TIME OTHER THAN IN ACCORDANCE WITH DIRECTIONS, BECAUSE PLANT INJURY, EXCESSIVE RESIDUES OR OTHER UNDESIRABLE RESULTS MAY OCCUR.

\section{NOTICE}

Platte Chemical Co., Inc., warrants that this material conforms to the chemical description on the label and is reasonably fit for the purposes referred to in the directions for use. This product is sold with the understanding that the buyer assumes all risks of use or handling which may result in loss or damage which are beyond the control of the seller, such as incompatibility with other products, the manner of its use or application, or the presence of other products or materials in or on the soil or crop. Platte Chemical Co. Inc. or any other seller, for any and all losses, injuries, or damages resulting from the use or handling of this product shall be the purchase price paid by the user or buyer for the quantity of this product Involved. The buyer and all users are deemed to have accepted the terms of this notıce, which may not be varied by any verbal or written agreement.

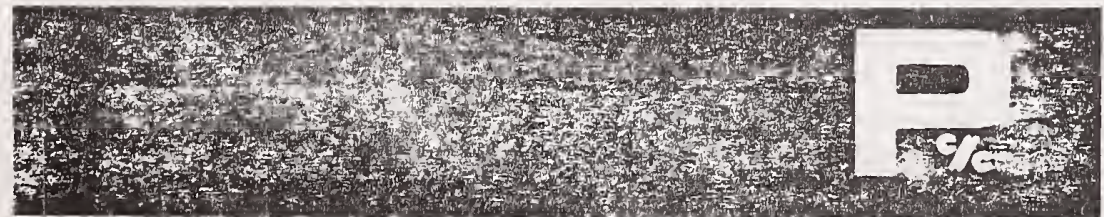




\section{APPENDIX D}

Details of conditions and equipment used during field experiments with endrin, chlorpyrifos, and permethrin, May - June 1982.

\begin{tabular}{|c|c|c|c|}
\hline \multirow[b]{2}{*}{ Parameter } & \multicolumn{3}{|c|}{ Test Application Details } \\
\hline & Lavina & Shawmut & Vaughn \\
\hline Aircraft Type & $\begin{array}{l}\text { Grumman Super G } \\
164 \mathrm{~A} \text { Ag. Cat, } \\
\text { Droop Tip Bi- } \\
\text { plane }\end{array}$ & Ag. Truck & Piper Pawnee \\
\hline Nozzle Size & $1046 \mathrm{D} 10$ & D 10 and 45 & D 6 and 45 \\
\hline $\begin{array}{c}\text { Boom Pressure } \\
\text { (psi) }\end{array}$ & 40 & 30 & 25 \\
\hline $\begin{array}{l}\text { Flying Speed } \\
\text { (mph) }\end{array}$ & 105 & 120 & 95 \\
\hline $\begin{array}{l}\text { Release Height } \\
\text { (ft) }\end{array}$ & t & 8 & 8 \\
\hline $\begin{array}{l}\text { Swath Width } \\
\text { (ft). }\end{array}$ & 60 & 50 & 35 \\
\hline Carrier & $\begin{array}{l}\text { Xylene Solvent } \\
\text { or water }\end{array}$ & Water & Water \\
\hline $\begin{array}{l}\text { Application } \\
\text { Rate } \\
\text { (Ibs AI/A) }\end{array}$ & $\begin{aligned} \text { Endrin } & =0.25 \\
\text { Chlorpyrifos } & =0.90 \\
\text { Permethrin } & =0.10\end{aligned}$ & Chlorpyrifos $=0.50$ & Permethrin $=0.10$ \\
\hline Air Temp ( $\left.{ }^{O} \mathrm{~F}\right)$ & 68 & 55 & 50 \\
\hline $\begin{array}{l}\text { Wind Vel } \\
\text { (mph) }\end{array}$ & 5, gusting to 10 & $5-7$ & 1 \\
\hline Wind Directior & SSW & ENE & ENE \\
\hline
\end{tabular}


Results of public awareness survey concerning pesticide contamination of Montana game birds, 1982.

\section{Introduction Section}

Sample Size Drawn $=200$ bird license holders (Resident)

No. of People Surveyed $=162$ ( 81 percent contact rate)

Question 非1. Were you or any of your household aware that some game birds were contaminated with pesticides and that certain precautions were recommended to be taken in preparing them for human consumption?

Response: 158 (98 percent) Yes

4 ( 2 percent) No

Question 非. How did you learn of this contamination?

Note: Respondents were allowed to acknowledge up to three most significant choices.

Response: 115 (73 percent) Newspaper

72 (46 percent) Television

52 (33 percent) Radio

24 (15 percent) Word of Mouth

11 ( 7 percent) License Dealer

11 ( 7 percent) Other

\section{Upland Game Bird Section}

Question 非1. How do you feel about pesticide-contaminated upland game birds?

Response: 40 (25 percent) Greatly concerned

52 (33 percent) Moderately concerned

24 (15 percent) Slightly concerned

41 (26 percent) Not worried at all

Question \#2. Did you or anyone in your household hunt upland game birds this past season?

Response: 104 (66 percent) Yes

53 (34 percent) No 
2(a) Did your knowledge of pesticide-contamination of upland game birds affect your decision not to hunt upland game birds this year?

Note: This question related only to those respondents who did not hunt.

Response: 37 (71 percent) Not at all

4 ( 8 percent) Slightly

5 (10 percent) Significantly

$\frac{6}{52}(12$ percent) Major reason

Comment: The sportsmen who learned of the pesticide contamination prior to purchasing the 1982 Upland Game Bird License and chose not to purchase the license because of the problem, are not in this sample. Thus, holders who did not hunt upland game birds because of the contamination were sportsmen who purchased a bird license in combination with another license (i.e. sportsman license) or had not sufficient information at the time of purchase.

2(b) Were you given any upland game birds this year that your household consumed or plans to consume?

Response: 2 ( 4 percent) Yes

50 (96 percent) No

Question \#3. How many upland game birds harvested this year has your household consumed?

Response:

Number of households consuming upland game birds (September 1 - December 31).

\# birds consumed per household

Total Average

Hse- Total \# birds/

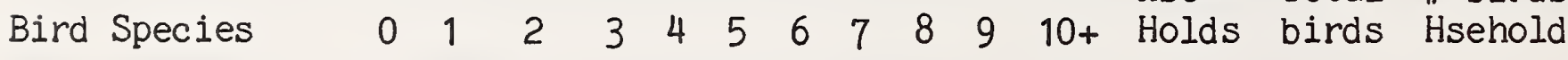

Mtn grouse

Farmland birds

$\begin{array}{llllllllllllll}45 & 3 & 6 & 1 & 5 & 0 & 5 & 1 & 2 & 2 & 6 & 76 & 169 & 2.22\end{array}$

Sharp-tailed grouse

Sage grouse

$\begin{array}{rrrrrrrrrrrrrr}35 & 8 & 10 & 11 & 1 & 1 & 6 & 0 & 0 & 1 & 3 & 76 & 149 & 1.96 \\ 54 & 4 & 4 & 3 & 1 & 2 & 2 & 0 & 2 & 1 & 3 & 76 & 161 & 2.12 \\ 61 & 1 & 3 & 4 & 1 & 1 & 2 & 1 & 1 & 0 & 1 & 76 & \frac{80}{559} & \frac{1.05}{7.36}\end{array}$


Question 非. How many upland game birds harvested this year has your household either frozen or otherwise preserved that will be consumed this year?

Response:

Number of households with preserved upland game birds as of January 1, 1983.

\# birds preserved per household

Total

Hse- Total

Av. 非 of

Mtn grouse

$\begin{array}{llllllllllll}58 & 3 & 6 & 3 & 3 & 1 & 2 & 0 & 0 & 0 & 0 & 76\end{array}$

53

60

0.70

Farmland birds

Sharp-tailed

grouse

Sage grouse

$\begin{array}{llllllllllll}69 & 0 & 3 & 2 & 0 & 1 & 0 & 0 & 0 & 1 & 0 & 76\end{array}$

$\begin{array}{llllllllllll}69 & 0 & 3 & 2 & 0 & 1 & 0 & 0 & 0 & 1 & 0 & 76\end{array}$

$\begin{array}{rr}30 & 0.39 \\ 27 & \frac{0.36}{2.24}\end{array}$

Question 非. Now I need to know the number of people in your household who have eaten or will eat upland game birds this year?

Response:

Number of households with members eating upland game birds.

非 people per household

$\begin{array}{llllllllllll}\text { Sex/Age of members } & 0 & 1 & 2 & 3 & 4 & 5 & 6 & 7 & 8 & 9 & \begin{array}{l}\text { Average numb household } \\ \text { hould }\end{array}\end{array}$

Females/over 35

Males/over 13

Females/13-35

Males $/ 0-12$

Females $/ 0-12$ $\begin{array}{rrrrrrrrr}36 & 4 & 0 & 0 & 0 & 0 & 0 & 0 & 0 \\ 54 & 14 & 5 & 4 & 2 & 1 & 0 & 0 & 0\end{array}$

$\begin{array}{lllllllll}33 & 2 & 1 & 1 & 0 & 0 & 0 & 0 & 0\end{array}$

$\begin{array}{lllllllll}20 & 4 & 0 & 0 & 0 & 0 & 0 & 0 & 1\end{array}$

$\begin{array}{lllllllll}12 & 3 & 1 & 0 & 1 & 0 & 0 & 0 & 0\end{array}$
0.58

1.69

0.58

0.49

0.34

Question 非6. Between September 1 and December 31, were there any pregnant women or nursing mothers in your household?

Response: 5 Nursing or pregnant 
Question $\#^{7}$. Were any of the birds consumed by pregnant women or nursing mothers?

Response: a. Pregnant 1 ( 1 percent) Yes

75 (99 percent) No

b. Nursing 1 ( 1 percent) Yes

75 (99 percent) No

Comment: These two positive responses were different people.

Question 非. The following questions relate to how the upland game birds were prepared.

Response: a. Were the birds skinned?

74 (97 percent) Yes

2 ( 3 percent) No

b. Did you remove the fat from the body of the bird?

73 (96 percent) Yes

3 ( 4 percent) No

c. If the bird was stuffed, was the dressing eaten?

6 ( 8 percent) Yes

70 (92 percent) No

d. Were the drippings discarded?

61 (80 percent) Yes

15 (20 percent) No

\section{Waterfowl Section}

Question 非1. How do you feel about pesticide-contaminated waterfow 1?

Response: 43 (27 percent) Greatly concerned

52 (33 percent) Moderately concerned

26 (17 percent) Slightly concerned

36 (23 percent) Not worried at all 
Question 非. Did you or anyone in your household hunt waterfowl this past season?

Reponse : 53 (34 percent) Yes

105 (66 percent) No

Note: The upland game bird license is a prerequisite to the federal waterfowl stamp. It is likely that nearly all the "no" respondents did not have a waterfowl stamp.

2(a) Did your knowledge of pesticide contamination of waterfowl affect your decision not to hunt waterfowl this year?

Note: This question relates only to those respondents who did not hunt.

Response: 73 (70 percent) Not at all

6 ( 6 percent) Slightly

7 ( 7 percent) Significantly

18 (17 percent) Major reason

2(b) Were you given any ducks or geese this year that your household consumed or plans to consume?

Response: $\quad 1$ ( 1 percent) Yes

103 (99 percent) No

Question 3. How many ducks and geese harvested this year has your household consumed?

Response:

Numbers of households consuming waterfowl (September 1 - December 31).

\# birds consumed per household

\begin{tabular}{|c|c|c|c|c|c|c|c|c|c|c|c|c|c|c|}
\hline \multirow[b]{2}{*}{$\begin{array}{l}\text { Waterfowl } \\
\text { Species }\end{array}$} & & \multirow{2}{*}{$\begin{array}{l}\text { Total } \\
\text { House- } \\
\text { holds }\end{array}$} & \multirow[b]{2}{*}{$\begin{array}{l}\text { Total } \\
\text { birds }\end{array}$} & \multirow{2}{*}{$\begin{array}{l}\text { Av. No. } \\
\text { birds/ } \\
\text { hsehold }\end{array}$} \\
\hline & 0 & 1 & 2 & 3 & 4 & 5 & 6 & 7 & 8 & 9 & $10+$ & & & \\
\hline Ducks & 11 & 4 & 8 & 4 & 0 & 0 & 2 & 0 & 1 & 1 & 7 & 38 & 256 & 6.74 \\
\hline Geese & 26 & 6 & 2 & 3 & 0 & 0 & 1 & 0 & 0 & 0 & 0 & 38 & $\frac{25}{281}$ & $\frac{.66}{7 \cdot 39}$ \\
\hline
\end{tabular}


Question 非4. How many wild ducks and geese harvested this year does your household have either frozen or otherwise preserved that will be consumed this year?

Response:

Number of households with preserved waterfowl.

\# birds preserved/household

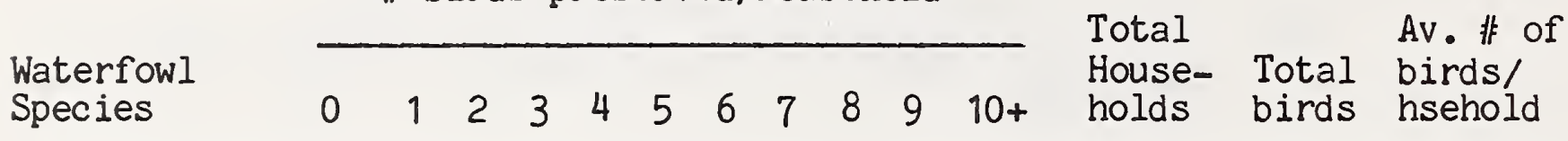

Ducks

$\begin{array}{llllllllllll}26 & 4 & 2 & 0 & 0 & 0 & 2 & 1 & 1 & 0 & 2\end{array}$

$\begin{array}{lll}38 & 65 & 1.71 \\ 38 & \frac{13}{78} & \mathbf{2 . 3 4} \\ & 2.05\end{array}$

Question 非. Now I need to know the number of people in your household who have eaten or will eat waterfowl this year.

Response:

Number of households with members eating waterfowl.

\# people per household

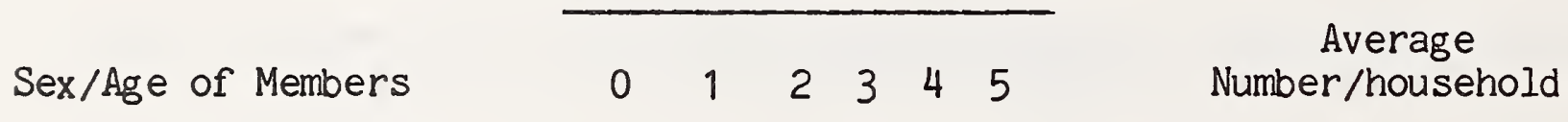

Females/over 35

Males/over 13

Females/13-35

Males $/ 0-12$

Females/0-12

$\begin{array}{rrrrr}16 & 2 & 0 & 0 & 0 \\ 23 & 8 & 2 & 2 & 2 \\ 20 & 2 & 0 & 0 & 0 \\ 10 & 1 & 0 & 0 & 0 \\ 6 & 1 & 0 & 0 & 1\end{array}$

0.53

1.66

0.63

0.32

0.34

3.48

Question 非6. Between September 1 and December 31, were there any pregnant women or nursing mothers in your household?

Response: 3 Nursing or pregnant 
Question \#7. Were any of the birds consumed by pregnant women or nursing mothers?

Response: Pregnant 2 ( 5 percent) Yes

36 (95 percent) No

Nursing 2 (5 percent) Yes

36 (95 percent) No

Question \#8. The following questions relate to how the ducks or geese were prepared.

Response: a. Were the birds skinned?

27 (82 percent) Yes

6 (18 percent) No

b. Did you remove the fat from the body of the bird?

29 (87 percent) Yes

4 (13 percent) No

c. If the bird was stuffed, was the dressing eaten?
0
Yes
33 (100 percent) No

d. Were the drippings discarded?

28 (85 percent) Yes

5 (15 percent) No

Question \#9. Do you feel you were adequately informed regarding pesticide contamination in upland game birds and waterfowl?

Response: 137 (87 percent) Yes

21 (13 percent) No 


\section{APPENDIX F}

Precautionary Poster Distributed to Hunting License Dealers and others Prior to 1981 Upland Game Bird Hunting Seasons in Montana 
HUMAN INGESTION OF ENDRIN VIA CONTAMINATED WATERFOWL

- Worst Case Scenarios -

The World Health Organization has established and the U.S. Environmental Protection Agency has adopted $0.0002 \mathrm{mg} / \mathrm{kg}$ as the acceptable daily intake (ADI) level for endrin by humans.

In calculating what levels of endrin could be ingested by humans, the assumption is made that either 400 grams of meat (wet flesh) or 400 grams of meat plus 50 grams of fat (wet flesh) would be eaten in one day. Those amounts represent 14-16 ounces of flesh, or about 1 pound.

\begin{tabular}{|c|c|c|c|c|c|c|}
\hline \multirow[b]{3}{*}{ Species } & \multirow{2}{*}{\multicolumn{2}{|c|}{ PPM Endrin in: }} & \multicolumn{4}{|c|}{ Endrin ingested (mg $/ \mathrm{kg})$ by $a_{\text {: }}$} \\
\hline & & & 50 It & $(\mathrm{kg})$ child & 150 I & $8.1 \mathrm{~kg}$ ) AduIt \\
\hline & Eat & Meat & Meat & Meat \& Fat & Meat & Meat \& Fat \\
\hline Canada Goose & .52 & .019 & .00033 & .00148 & .00011 & .00049 \\
\hline Mallard & 1.35 & $(.0202)^{*}$ & .00036 & .00333 & .00012 & .00111 \\
\hline Gadwall & .32 & $(.0048) *$ & .00008 & .00079 & .00003 & .00026 \\
\hline Wigeon & 1.2 & .005 & .00009 & .00273 & .00003 & .00092 \\
\hline $\begin{array}{l}\text { Blue-winged } \\
\text { Teal }\end{array}$ & .88 & .013 & .00023 & .00217 & .00008 & .00072 \\
\hline
\end{tabular}

* No endrin test conducted on meat; based on other endrin fat:meat ratios, the endrin in meat was assumed to be $1.5 \%$ in fat

Montana Department of $\mathrm{F}$ ish, WildIife and Parks 9-24-81 


\section{APPENDIX H}

Opinions on the Hazards to Humans Consuming Endrin-Contaminated Wildife 
REF: $8 M 0$

Mr. Jim Flynn, Director

Department of Fish, Wildlife and Parks

1420 East Sixth Avenue

Helena, Montana 59620

Dear Mr. Flynn:

This morning Governor Schwinden asked me to inform you of the EPA's position regarding the recent discovery of Endrin in certain game birds. I wish to note that EPA's position on this matter is advisatory in nature and is not our intention to interfere with the normal State decision-making process.

We feel there is no danger to public health posed by the consumption of affected game birds. Danger to humans has been overstated due to misuse of the allowable daily intake (ADI) figure for Endrin. Naturally, the public should take reasonable precautions when consuming potentially contaminated game birds. We recommend that the birds be skinned and the fat and entrails discarded prior to the consumption of the birds.

I appreciate the complexity of this issue and would like to offer our assistance. The EPA laboratory in Denver is available to assist with Endrin analyses of birds, soil, water, etc. Please have your staff call Irv Dickstein (303-837-4935) for details on our laboratory capabilities. Please feel free to call if I can be of assistance.

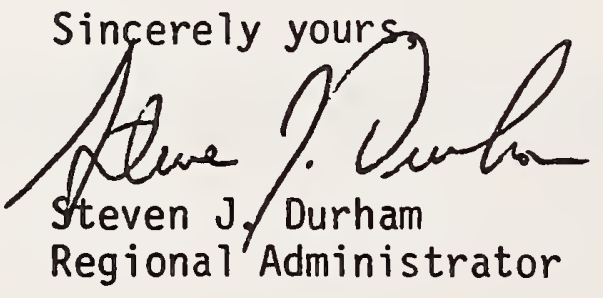


Mr. James W. Flynn, Director

Department of Fish, Wildlife and Parks

Helena, Montana 56920 .

Dear Mr. Flynn:

I appreciate receiving your letter of September 11, 1981, concerning the endrin levels in wild game birds in Montana. We both realize that there is insufficient information available for you to answer all the questions, I would ask to properly interpret the data. Therefore, my reply to you will be divided into two parts. The first giving you disposition of the birds as if I were confronted with such a problem in domestic fow 1 and secondly, my thoughts on what the data may indicate.

The disposition of the birds, using the current action level for endrin of $0.3 \mathrm{ppm}$ in fat would be to not accept the grouse or ducks without further processing. The Canadian geese would be acceptable. The ducks and grouse could be successfully further processed by removal of skin, body fat and other trimmable fat prior to cooking. In essence, this is in agreement with your current recommendations on grouse.

Looking at the data and making some assumptions, which you may be able to verify. The grouse are non-migratory birds and can act as an indice of local exposure. Therefore, the ducks sampled are probably native wild ducks and the differences in fat level is due to the differences in degree of exposure (ducks should be higher). The Canadian geese are definitely migratory, and once removed from exposure, should drop in level quickly (This is a function of redistribution, not excreation. I just don't believe body balance occurs in less than 3-4 weeks). Continued exposure may continue to increase levels in the geese. They also may serve as a guide of what to expect in ducks migrating from Canada.

Another little known fact, outside of analytical laboratories is that heating $f$ at in the rendering process over $100-110^{\circ} \mathrm{C}\left(212-230^{\circ} \mathrm{F}\right)$ will cause a loss of chlorinated hydrocarbon residues. This can act as an additional safety factor if the game is cooked on wire racks and kept out of any grease drippings. This may help your home economists to figure out ways to improve safety by cooking procedures. 
The above information was essentially given to Mr. Stan Bradshaw on September 18 , by telephone. Naturally, I defer to the experts in the Environmental Protection Agency (EPA) as to the allowable degree of human exposure.

Sincere $1 y$,

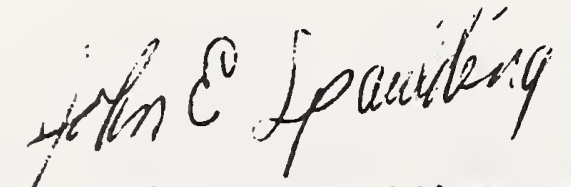

Dr. John E. Spaulding, Director

Residue Evaluation and Surveillance Division 
SEP 241981

VAN DERBILT UN IVES I TY

NASHVILLE, TENNESSEE 37232

TELEPHONE (615) 322.731

Center in Toxicology - Department of Biochemistry - School of Medicine - Scission 17 - Direct phone 1222261

21 Septencher 1981

Mu. Stan Bradshaw

Staff Attorney

State of Montana

Department If Fish and Gauze

Helena, m! 59620

Dear Mr. Bradshaw:

$\rightarrow$ Think the enclosed copy of the section o endrin taken from page proof of my bork Pesticides Studied in Man ought to answer your question. $\checkmark$ do not think There is any danger. If a grown person ate $200 \mathrm{~g}$ of far beaming the highest residue you have measured (1.2 ppr), he would receive $0.24 \mathrm{mg}$ an $0.0034 \mathrm{mg} / \mathrm{kg}$. This is considerably les Than a rate of 0.0140 mg/kg I day i which is cusiolered safe for a lifetime of vecupational es procure of may be wise to adopt the same policy for geese and dicker that your now have for prose. It is a highly conservative policy because the A2) is highly conservative. Yo may the interested that for meany years land perhaps now) the entire subcontinent

202 
of India was in violation of the ADI for DDT without any evidence of injury to The population.

From a scientific standpoint; S fried it interesting That birds store endrin whereas mamsualer do not store measurable enceutrations unless Their dosage is sufficient to produce poisoning.

With very beat wishes,

Sincerely,

Wayland 1. tapes, f, m. Di, Pho. D.

Profess ar of Birchencistry

203 


\title{
Rocky Mountain Poison Center
}

\author{
West 8th \& Cherokee - Denver, Colorado 80204 \\ Foison Information and Emergency. 303:629 1123 - Administiation 303/893 1774 \\ Colorado Toll Fine (Outside Metro Denver): 8003332.3073
}

September 22, 1981

\author{
Stan Bradshaw \\ Attorney \\ Montana State Fish and Game \\ Commission \\ Helena, Montana 56920
}

Dear Mr. Bradshaw:

This is in regard to endrin contamination of upland game birds. I will make reference to a 12 page report to the Fish and Game Commission of September 4, 1981 and to the letter from James W. Flynn to me dated September 1l, 1981. I will also make reference to the additional data provided on Canadian geese in terms of fat and meat levels.

After considering all of the data provided me and reviewing what medical literature exists as well as the extensive experience here at the Rocky Mountain Poison Center, I would like to provide you with a number of recommendations:

1. At the levels measured of this pesticide, some of ducks and geese will have sufficient endrin to provide greater than acceptable daily intake levels of $0.0002 \mathrm{mg} / \mathrm{kg}$. Calculations of ADI based on measured levels are in regard to raw meat and fat. Since the EPA and the World Health Organization agree with this, even in view of the enormous safety factor, this is a level that we cannot recommend be exceeded.

2. If sufficient fat, which is the major storage depot is removed from some of these birds, such as the Hungarian partridge, then the fat content would be low enough not to exceed the ADI. The teratogen level, calculated on meat would probably be exceeded, leading to a recommendation that women in the lst three months of pregnancy avoid these game birds.

3. It is possible that cooking of these animals will remove most of the contaminated tissue - the fat. Since most individuals cook these birds at approximately $350^{\circ} \mathrm{F}$ and usually do this on a rack of some sort, most of the fat would then be rendered from the bird. In order to take advantage of this selective removal, we would suggest that the fat not be utilized in the making of gravy. Additionally, we would suggest that 
stuffing the animal not be performed, since stuffing would absorb some of the fat and then be ingested. The skin is extremely high in fat content and should be discarded. Internal organs, which are not generally ingested from these birds should also be discarded. The major organ which should not be eaten is the liver. The heart and gizzard are probably acceptable.

4. There is inconclusive evidence in the medical literature about how much of the endrin would be absorbed and taken up into human tissue. There have been several acute accidents after which little, if any, has been found in the patient. There have also been several chronic exposures in various endrin workers who have had little, if any, in the fat. Unfortunately, there are also some cases in which the reverse has been true and fairly high accumulations have been recorded.

5. The question of season to season accumulation in the fat of humans who eat large quantities of these birds is of concern. Since the half-life of endrin (time period in which half of that which is in the body is excreted) is probably very long (several years or more) then accumulation could potentially occur. This is probably not a problem if the ADI is not exceeded. There have been some studies in animals showing shorter half-lives, however, these articles were unavailable to me.

6. These pesticides are all highly concentrated in breast milk. Since this is a major route of excretion, it should be made very clear that women who are breast feeding infants absolutely, under no circumstances, must ingest any part of these game birds. This is one area in which a very strong statement should be made.

I spoke with representative of Velsicol, the major manufacturer of endrin in the United States and asked him the effect of $350^{\circ}$ heat on endrin. He told me that there were studies on several other hydrocarbons of this family that showed major reduction of residue fcllowing heating. This data has not been available for endrin. We do know that 2 of the major breakdown products of endrin are the delta ketone and the alcohol, both of which are much less active, at least acutely. It was his opinion, although the experimental procedure has not been done, that some of the endrin would be destroyed upon cooking and that the remainder would be in the rendered fat. He agreed with me that these experiments should be carried out. Preliminary data from Gary Gingery of the Montana Department of Agriculture has demonstrated to difference pre and post cocking.

My opinion, in summary, is that occasional eaters of this wildlife, such as individuals eating part of a goose for Thanksgiving and Christmas and perhaps 3 or 4 other birds during the course of a year, should have essentially no risk, if they follow the precautions as listed above. The only concern we would have would be with those individuals who fill their freezers with these game birds and eat them on a continuous and heavy basis all year long. 
Stan Bradshaw

Scptember 22, 1981

Page 3

I have spoken to several people in the Department of Health and Environmental Sciences and I think that we are in basic agreement concerning these issues.

If I can be of any further assistance to you, I would be pleased to do so.

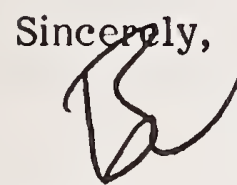

Barry H. Rumack, M.D.

Associate Professor of Pediatrics

Director, Rocky Mountain Poison Center

BHR:pb 


\section{DEPARTMENT OF HEALTH AN'ND \\ ENVIRONMENTAL SCIENCES}

DIRECTOR'S OFFICE

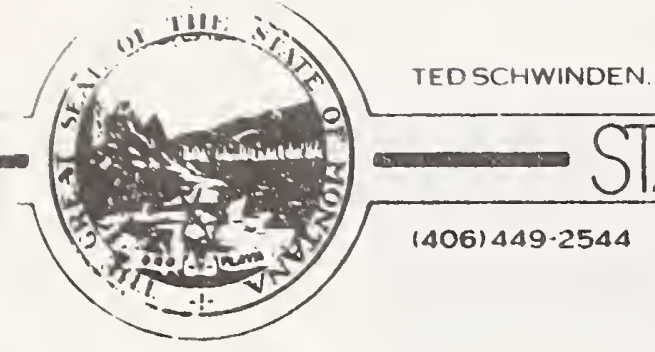

August 27, 1981

James W. Flynn, Director

Dept. of Fish, Wildlife and Parks

Capitol Station

Helena, Montana 59620

Dear Jim:

Regards recommendations to hunters of Endrin-sprayed areas, the Department of Health and Environmental Sciences, after consulting with various other concerns, does promulgate the following:

1) If all samples are negative for Endrin, no precautions are needed by consumers of game animals. This presumes that good sampling procedures were used and that the laboratory results were accurate.

2) It is the recommendation of the Department of Health and Environmental Sciences that all game species which have been shown to have Endrin fat concentrations of $0.3 \mathrm{ppm}$ or greater by laboratory analysis should not be consumed. Those game species, with no detection of Endrin, from affected areas would be consumable as the possibility of contamination is not likely to occur.

I would recommend that continuing surveillance of Endrin in game continue for the next two to three years in Endrin-sprayed areas, or at least until micro or undetectable amounts are established to have occurred in game in these areas and that the restrictions and warnings as outlined continue until such is accomplished.

Thank you.

Yours truily,

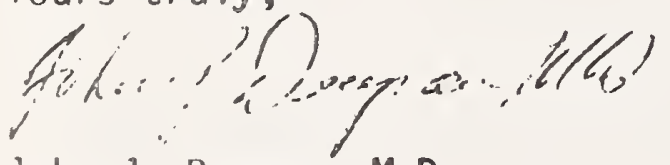

John J. Orynan, M.D.

Director

CC: James Glosser, DVM, Dept. of Livestock

Gordon McOmber, Dept. of Agriculture

Ron Marcoux, Dept. of Fish, Wildi ife and Parks 


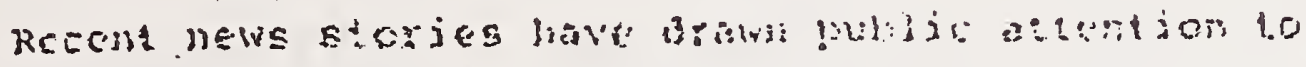

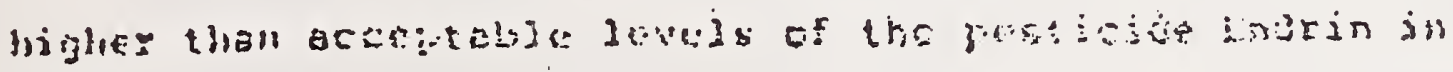

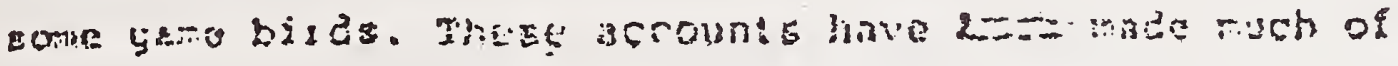

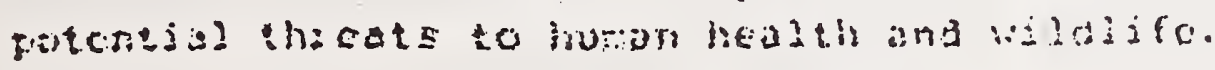

If bolieves that hese ctorias have unfortunately.

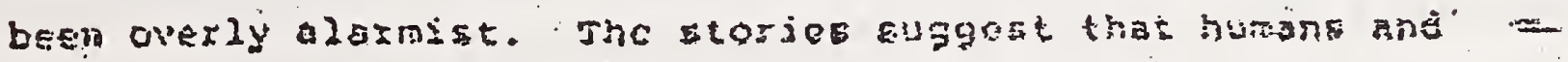

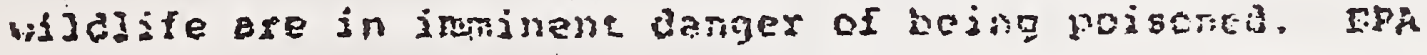

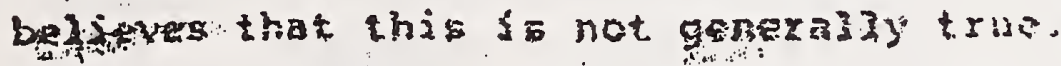
(n)

Danger to hutistis has seen overstated duc to nibuse of

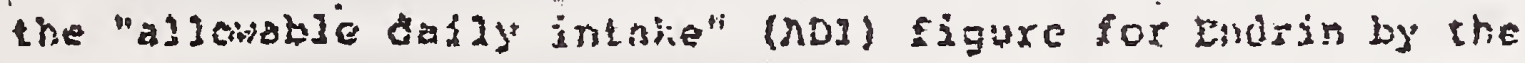

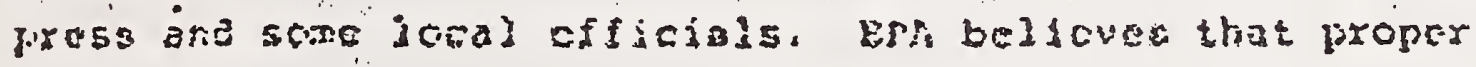

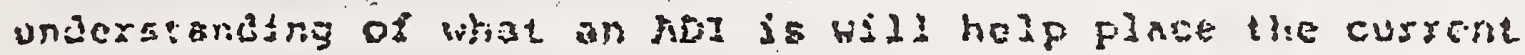
Erisgin "scage" into pax spective.

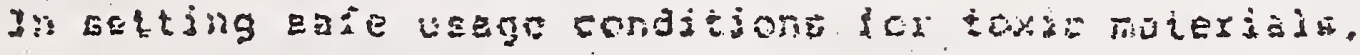

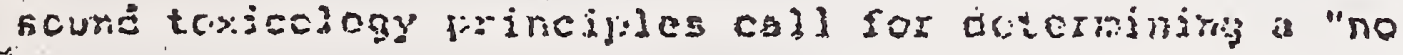

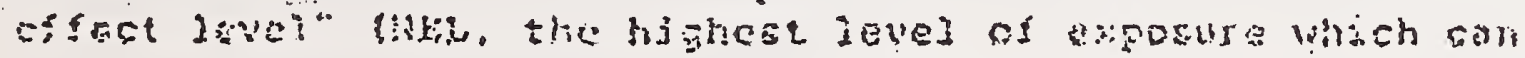

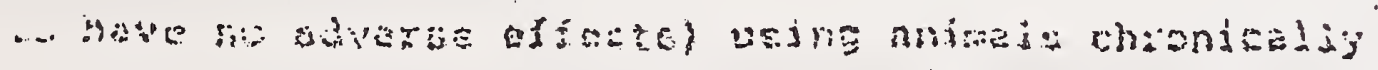

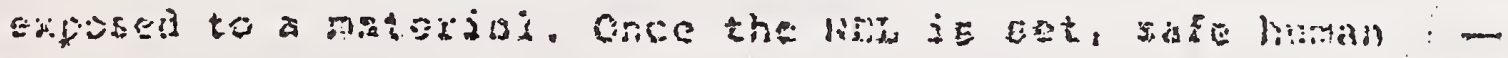

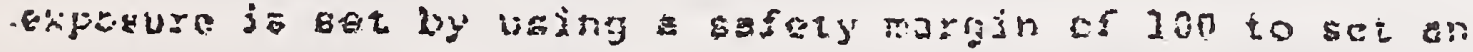

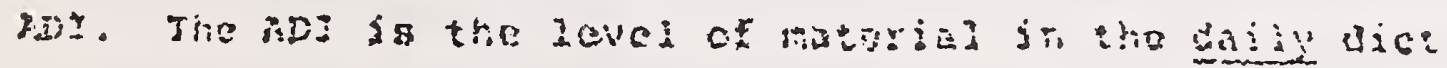

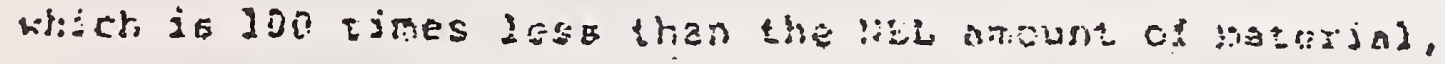

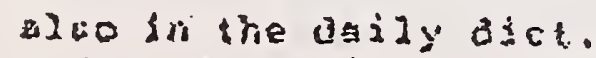




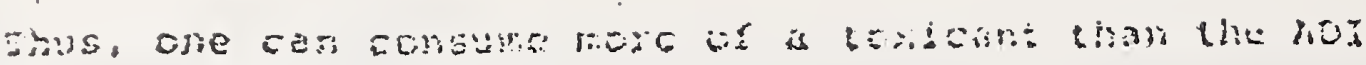

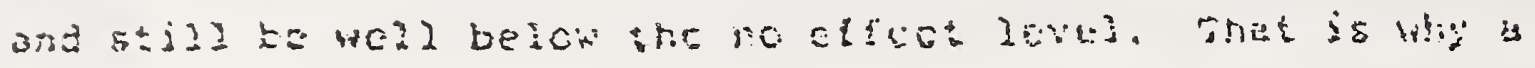

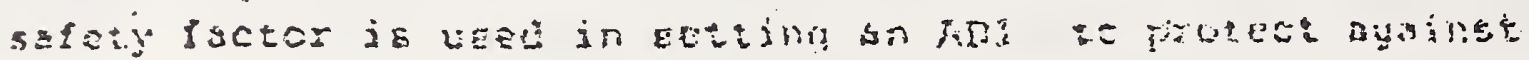

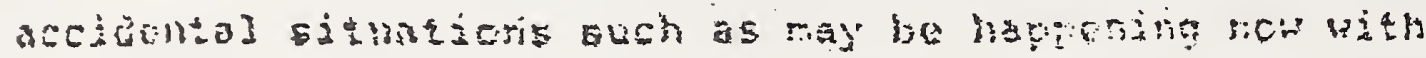

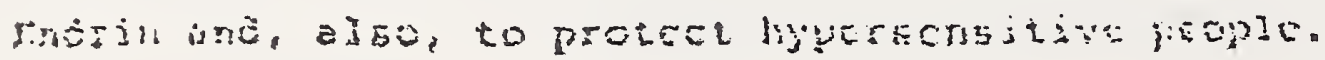

Dr. "3

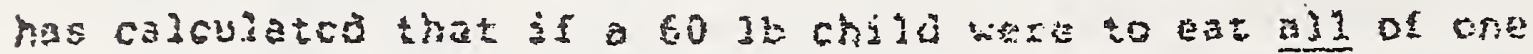
bdx of ine syecis

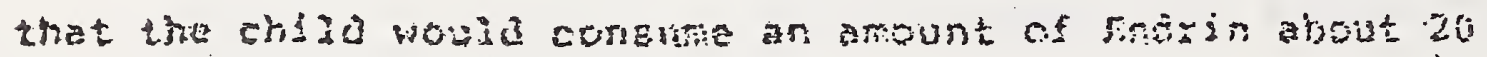

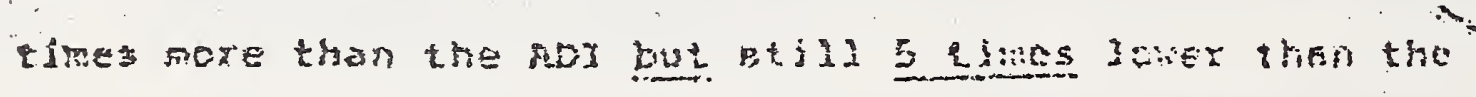

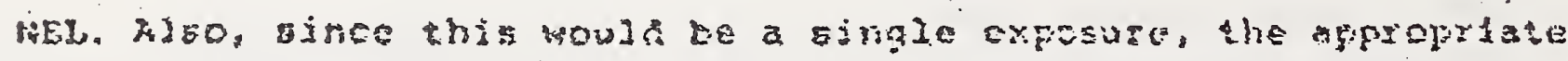

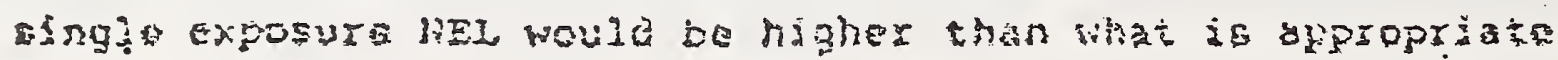

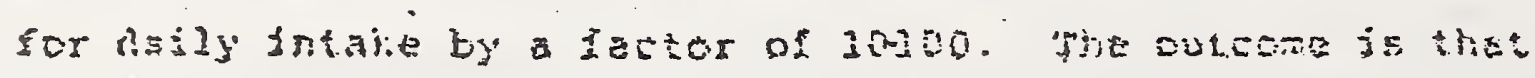

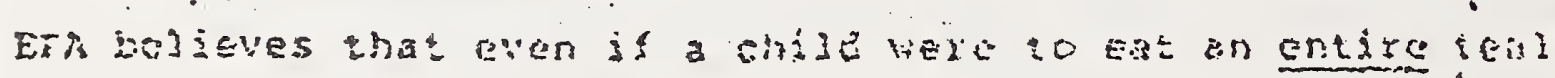

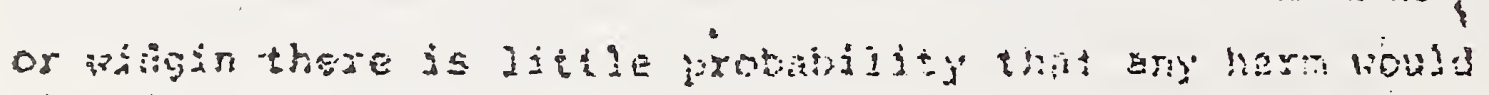

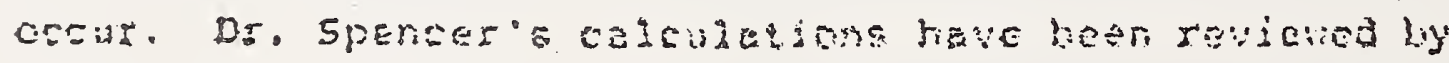

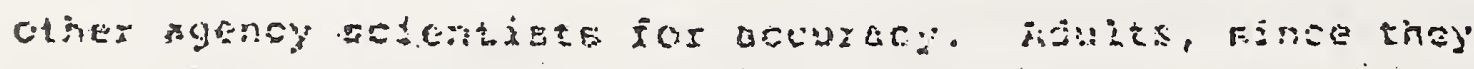

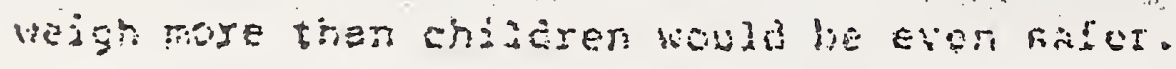

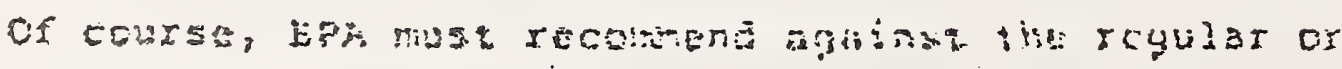

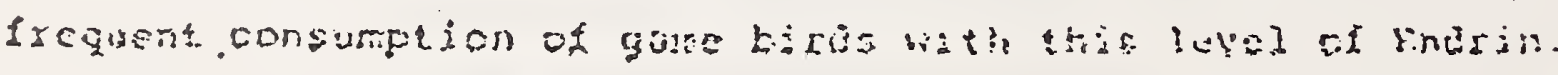

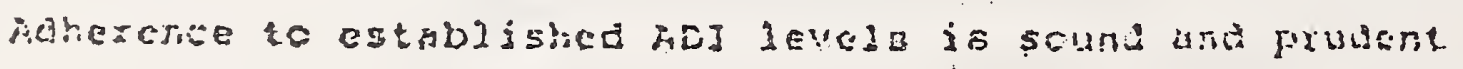
تL

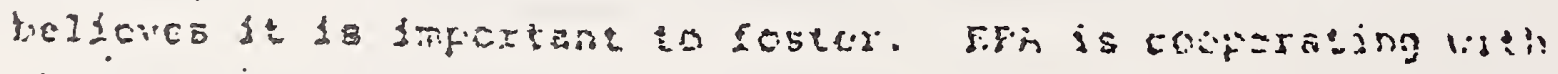

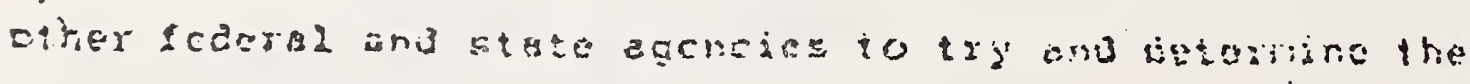


$1 \quad !^{4}$

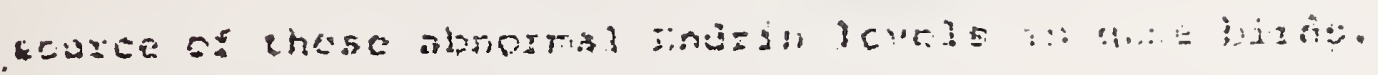

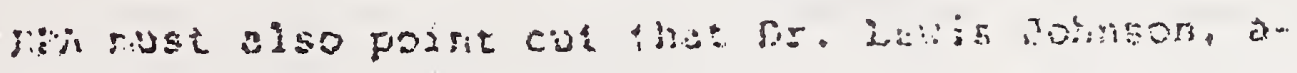

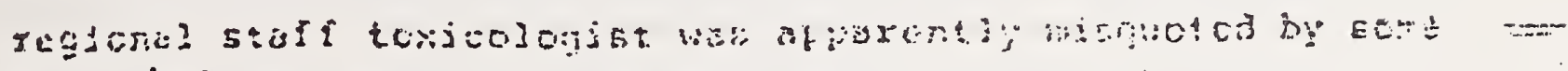

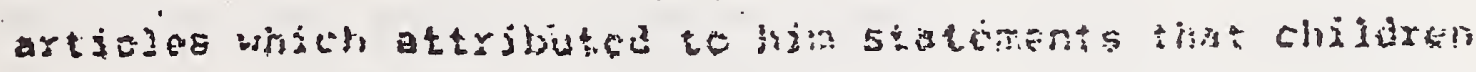

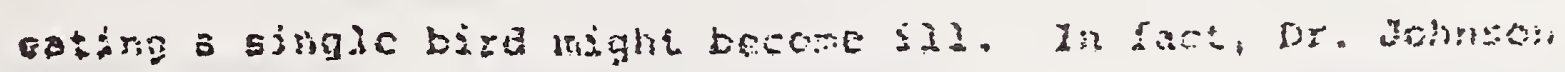

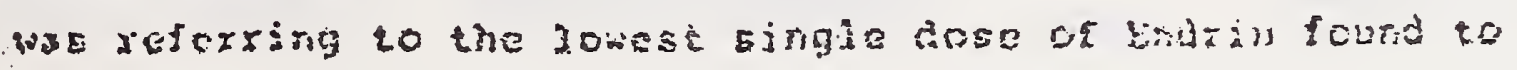

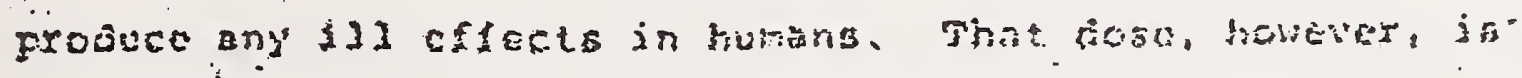

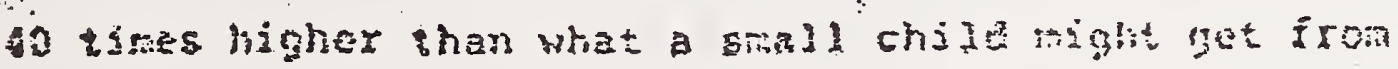

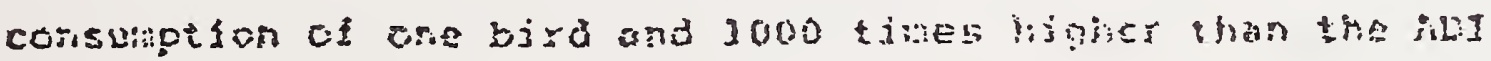

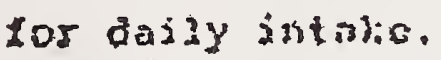

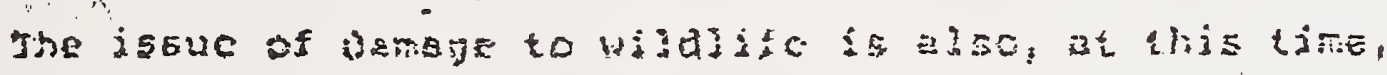

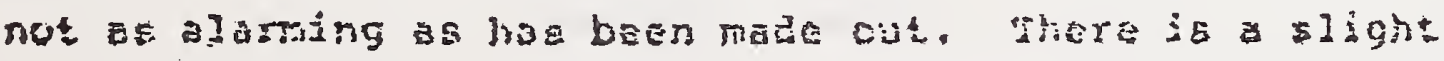

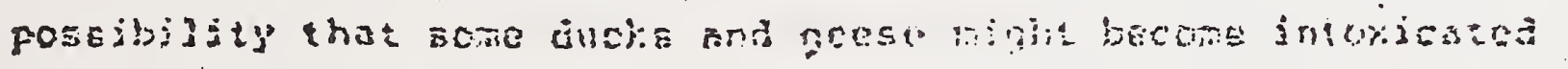

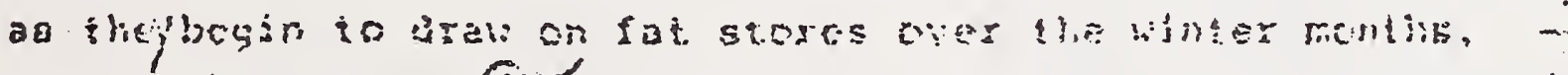

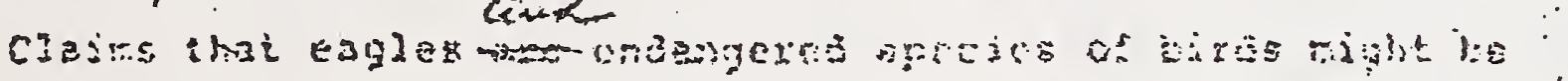

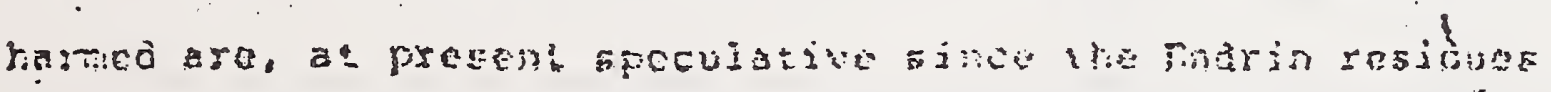

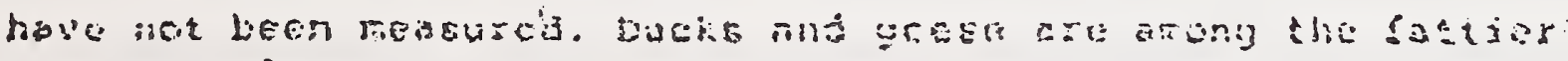

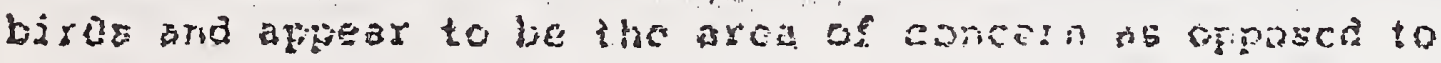
- grovse, eaphes or othet biros.

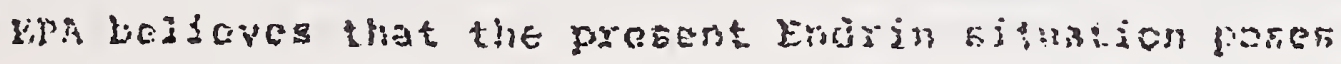

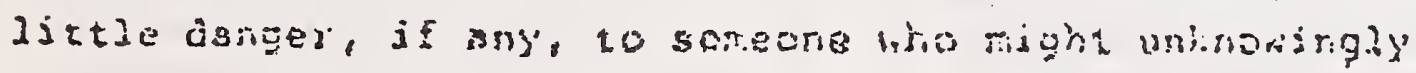

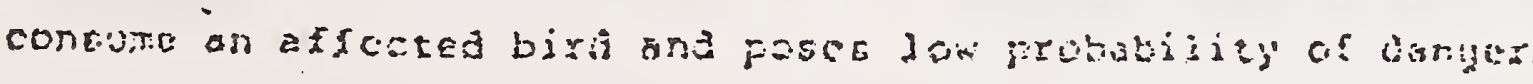

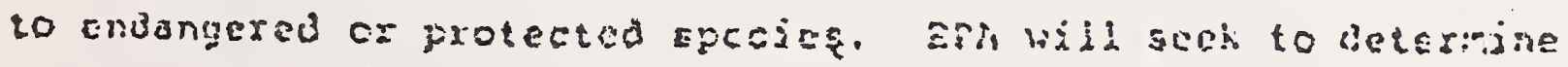

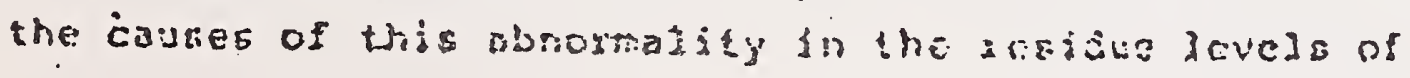

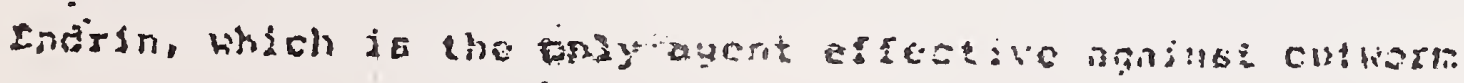


Stomach contents of birds collected on or near chlorpyrifos-treated wheat fields, 1982 (McEwen et al., in prep.).

\begin{tabular}{|c|c|c|c|c|c|c|c|}
\hline \multirow[b]{2}{*}{$\begin{array}{l}\text { Postspray } \\
\text { time } \\
\text { period }\end{array}$} & \multirow[b]{2}{*}{$\mathrm{n}$} & \multirow{2}{*}{$\begin{array}{l}\text { Percent } \\
\begin{array}{l}\text { Total } \\
\text { insects }\end{array}\end{array}$} & \multirow{2}{*}{$\frac{\text { Volume }}{\text { Seeds }}$} & \multicolumn{4}{|c|}{ Percent stomachs in which Order was found } \\
\hline & & & & $\begin{array}{l}\text { Lepid- } \\
\text { optera1/ }\end{array}$ & $\begin{array}{l}\text { Coleop- } \\
\text { tera }\end{array}$ & $\begin{array}{l}\text { Orthop- } \\
\text { tera2 }\end{array}$ & $\begin{array}{l}\text { Hymen- } \\
\text { optera } 3\end{array}$ \\
\hline & \multicolumn{7}{|c|}{ Horned Larks } \\
\hline 3 days & 21 & 50.0 & 47.6 & 95.2 & 47.6 & 0 & 47.6 \\
\hline $9-16$ days & 48 & $33.54 /$ & $65.04 /$ & 70.9 & 60.5 & 10.4 & 60.4 \\
\hline \multirow[t]{2}{*}{ Controls $5 /$} & 13 & 43.4 & 55.1 & $7 \cdot 7$ & 69.2 & $7 \cdot 7$ & 92.3 \\
\hline & \multicolumn{7}{|c|}{ McCown's Longspurs } \\
\hline 3 days & 4 & $70 \cdot 3^{6 /}$ & $29.7 \frac{6 /}{1}$ & 100.0 & 100.0 & 75.0 & 25.0 \\
\hline 9 days & 7 & 64.071 & 36.071 & 71.4 & 100.0 & 42.9 & $57 \cdot 1$ \\
\hline Controls $5 /$ & 11 & 46.9 & 52.1 & 27.2 & 81.8 & 54.5 & 72.7 \\
\hline
\end{tabular}

1/ Lepidoptera were largely pale western cutworms. A few stomachs contained army cutworms and/or other species of Lepidoptera (larvae and adults).

2) Orthoptera were grasshoppers and a few crickets.

3/ Hymenoptera were mostly ants.

4/ Differs from controls $(P<0.05)$ and from 3 days postspray $(P<0.01)$.

5/ Part of the control specimens were collected on rangeland $>1$ mile distant from wheat fields and part near the wheat fields prior to chlorpyrifos application.

6/ Differs from controls $(P<0.02)$.

I) Differs from controls $(P<0.05)$. 
Brain cholinesterase activity in birds collected at intervals on or near chlorpyrifos-treated wheat fields in Montana, 1982 (McEwen et al., in prep.).

\begin{tabular}{llll}
\hline $\begin{array}{l}\text { Posttreatment } \\
\text { interval (days) }\end{array}$ & $\begin{array}{l}\text { Mean brain } \\
\text { ChE activity } 1 / \\
(\mu \mathrm{m} / \mathrm{min} / \mathrm{g})\end{array}$ & S.D. & $\begin{array}{l}\text { No. birds in }- \\
\text { hibited }>20 \%\end{array}$ \\
\hline
\end{tabular}

Horned Larks

\begin{tabular}{ccccc}
3 & 16 & $13.53^{\mathrm{a}}$ & 2.05 & 8 \\
9 & 18 & $14.24^{\mathrm{a}}$ & 1.62 & 8 \\
16 & 20 & $15.99^{\mathrm{b}}$ & 1.56 & 1 \\
Control2/ & 5 & $17.36^{\mathrm{b}}$ & 1.31 & 0 \\
& & McCown's Longspurs & \\
3 & 4 & 24.13 & 2.04 & 0 \\
9 & 7 & 22.99 & 1.30 & 0 \\
Control3/ & 11 & 24.26 & 2.00 & 0 \\
\hline
\end{tabular}

1/ Means followed by the same letter do not differ ( $P>0.05)$.

2) Seven control birds were collected prior to the spray application but brains of 2 were not analyzed because of tissue damage from shot pellets. Six controls were collected from rangeland in the postspray interval but all brains were discarded; 2 because of shot damage and 4 because they may have been exposed to the chemical.

3/ Five birds were collected prior to the spray application and 6 were collected from rangeland $>1 \mathrm{mi}$ from sprayed fields in the postspray interval. 
Resolution Adopted by The Montana Chapter of The Wildife Society, 5 February 1982.

\author{
RESOLUTION OF \\ THE WILDLIFE SOCIETY, MONTANA CHAPTER
}

\author{
PESTICIDE MANAGEMENT IN MONTANA
}

WHEREAS, the Montana Chapter of the Wildlife Society is a nonprofit organization of professional wildlife biologists and others dedicated to preserving Montana's wildlife resources and their habitats; and

WHEREAS, this chapter further recognizes that people, as well as wildlife, are dependent on their environment and believes that wildlife in its many forms is basic to the maintenance of a quality existence for all Montanans; and

WHEREAS, all chlorinated hydrocarbon insecticides, including endrin, and strychnine are highly and acutely toxic to many forms of wild ife and are, therefore, incompatible with the management of wildlife resources in Montana; and

WHEREAS, the chlorinated hydrocarbon insecticides persist in the environment for up to 12 years or more; and

WHEREAS, we recognize that agriculture needs effective and species selective insecticides and their proper use in controlling pest species;

NOW THEREFORE, BE IT RESOLVED that the Montana Chapter of The Wildife Society recommends;

(1) the immediate and permanent termination of the use of all chlorinated hydrocarbon insecticides in Montana;

(2) the use of strychnine in Montana be limited to below ground surface applications; and

(3) that, in order to provide agriculture with less hazardous insect-pest control methods, the appropriate state agencies expedite research efforts to evaluate the effects of alternative control methods on wildife resources. 


\title{
APPENDIX L
}

\author{
Resolution Adopted by The Wildife Society Council \\ 15 September 1982.
}

\begin{abstract}
RESOLUTION ON THE FIELD USE
OF ENDRIN AND HEPTACHLOR
\end{abstract}

WHEREAS, The Wildlife Society is a nonprofit organization of professional wildlife biologists, resource managers, and others dedicated to managing and enhancing wildlife resources and their habitats; and

WHEREAS, The Wildlife Society recognizes that people, as well as wildlife, are dependent on their environments and believes that wildlife in its many forms is basic to the maintenance of a quality existence for all people; and

WHEREAS, the chlorinated hydrocarbon pesticides endrin and heptachlor are highly and acutely toxic to many forms of wildlife and are, therefore, incompatible with the management of wildlife resources; and

WHEREAS, field use of these chlorinated hydrocarbon pesticides disrupts ecosystems, and contaminated mobile species of wildlife transport these pesticides far beyond the original sites of application; and

WHEREAS, endrin and heptachlor and their metabolites persist in the environment 10 years and longer; and

WHEREAS, the position of The Wildlife Society in regard to toxic chemical compounds is stated in Conservation Policies of The Wildlife Society; and

WHEREAS, it is recognized that agriculture needs effective and species selective methods to control damage to agricultural crops;

NOW THEREFORE, BE IT RESOLVED that The Wildlife Society recommends:

(1) the immediate and permanent termination of the field use of endrin and heptachlor in the U.S. and other countries; and

(2) that appropriate governmental agencies increase the level of research and development on alternative control methods, including evaluation of their effects on wildlife populations and their habitats, to provide agriculture with less hazardous damage control methods. 
Resolution adopted by both the Central and Pacific Flyway Councils, 28 March 1982.

WHEREAS, endrin, a chlorinated hydrocarbon insecticide, has repeatedly proven to be incompatible with Fish and Wildlife resources and their management; and

WHEREAS, the widespread use of endrin to combat cutworms in cereal grains in Montana in 1981 resulted in the contamination of significant numbers of migratory waterfowl; and

WHEREAS, the endrin contamination of these waterfowl threatened the health of public consumers of these waterfowl; and

WHEREAS, the threat to public health disrupted and threatened the continuance of waterfowl hunting seasons in Montana and other states and provinces in the Central and Pacific Flyways in 1981;

NOW THEREFORE BE IT RESOLVED, that the Pacific Flyway Council encourages the pesticide industry, the EPA, agricultural community and federal and state wildlife agencies to develop and implement effective and economical alternative controls for cutworms which minimize the hazards to wildlife and public health. 


\section{APPENDIX N}

News Media Rank Endrin-Contamination of Wildlife as Number 2 News Story in Montana in 1981 
Excerpted from The Great Falis Tribune, 27 December 1981.

\section{Severance tax ruling heads list of top 10 1981 state news stories}

\section{BY JOHN KUGLIN}

HELENA (AP) - Montana's coal severance tax, worth almost $\$ 75$ million a year to the state's treasury. withstood a challenge in the U.S. Supreme Court during 1981; but its future was clouded by continued congressional assaults as the year drew to a close.

The Supreme Court's ruling in the lawsuit by protesting mining companies and coal-burning electric utilities was voted Montana's top news story of 1981, in a poll of Associated Press-member newspapers and broadcast stations.

The contamination of wildlife with the pesticide endrin. which causes birth defects in laboratory animals, was selected as the No. 2 story.

The other top 10 stories, in order, were:

3. Montana's faltering economy.

4. The spring floods in areas of western Montana.

5. Gov. Ted Schwinden's first year in office.

6. The Legislature's regular and special sessions.

7. The confrontation over control: of the Bighorn River through the Crow Indian Reservation.

8. Oil and gas development.

9. Burlington Northern's efforts to abandon hundreds of miles of railroad track and bypass small grain elevators.

10. The off-again, on-again plans to use the old Glasgow Air Force Base as a detention center for aliens.
Endrın. an agricultural chemical that most Montanans had never heard of. caused a pesticide horror story after it was spraved on thousands of acres of grain fields to kill cutworms.

The highly-toxic member of the DDT family killed the cutworms. but contaminated wildlife. In the confused weeks that followed, the Fish and Game Commission rejected pleas from health officials to cancel the waterfowl hunting seasons. About half the hunters stayed home. anyway.

Wildlife agencies in other states that share waterfow' flyways with Montana also becamed alarmed. but followed Montana's lead in allowing the hunting season to continue.

The state Department of Agricullure. which oversees pesticide use, obtained federal permission to use an alter. native cutworm pesticide, banned endrin for the rest of the year and activated the state pesticide advisory council.

Hearings were scheduled for early next year on propnsals to tighten pesticide regulations. 


\section{APPENDIX 0}

Public Demands Better Control of Potentially Dangerous Pesticides 
APPENDIX 0

From Bozeman Daily Chronicle, 31 August 1982.

\section{More pesticide control wanted}

HELENA (AP) - Conservationsts, Iesting which showed new cliemusat health officials, and citizens who said coneamination and worsening of known health orficis, and citizens who said they depend on will gaine for their meat called Monday for further government action to control potentially dangerous pesticides and yel to protec
Montana's valuable agricultural indus. try.

try. The testimony was given before the Legislate's Envis grivent beforethe Council, whose Iverson, R-Whitlash, unofficially ptedged the future attention of the council to the prablem.

The public testimony followed presentations by state wildlife, health and agriculture olficials concerning re cently discoverest traces of the pestiinde heptacilor and continued preselice of the pesticide endrin in samples

game birds in eastern Montana.

Tom Daubert of the Montana Environmental Information Center in Helena said state and federal agencies must make better information available and take stronger steps to control pesticides so that citizens no longer have to fear becoming victinis of a kind of "Russian roulette.

Daubert reminded EQC nembers that game bird hunting dropped by hal last year in the wake of reports of endrin contamination.

He said that experience, now complicated with discovery of heptachlor containination, could be the "beginnu! of the end of hunting in Montana."

Daubert said a continued or prot knnged periud of public ignorance usisinformation about pesticide effects III the food chain would also be disastrous for agriculture if the industry insists on "backing itself into rorner" on pesticide issues.

Dauben said the EQC. as an independent azency of legiss an indecitizens, is in the best position analyze the adequacy of state agency respunses to pesticide use and a ture. Will Selzer of the use and abuse. Cisunty Health Derartment called for legislation at the state level establish. ing an indernnity proarn which would cuilpensate frrity program which would arree 10 give up and others if they dangerous chemicals.

But Selzer said there aleo must be

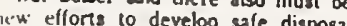
serethods and sites for pesticides in Voustana.

And he asked why game bird hunling

"dasus in Mesutand have not been

handoned this year in light of recen and existing stocks of heptachlor in Gordon McOinber said Monday tha
Ken Knudson vice president of the Ken Knudson. vice president of the Montana Wildile Federation. proposed three steps which he said

First. First, he said. There should be direct appropriation of public funds help develop sale substivutes lo endrim. heplachlor and orther pesticides danger He humans and wildlite He said the EQC and executse branch of state government should petition the U.S. Environmental Protection Agency to ban the use of endrin Montana.

And he saut ths state should take the lead in enlssing other states 11 similarly petition the EPA so that Montana will not simply have th source if its problems coming troin elsewhere.

Manufacture of heptachlor is being banned by the EPA. effective Wednes day, but state Agriculture Director W. some \$I initlion worth of the chemical remains in the mventory of Montana lased distributers which serve five states.

Selzer claimed that there was a scranible to stockpile the chemical after the Sept. I ban on manufacture was anilounced hut McOinber said he could inly sixeculate whether that was ve.

Noet Kusctla of the Montana Audu. bon Council sugkested that the EQC cunduct studies on what he said has been China's successful experience proven that it is not possible to determine whether sportsmen and Anderson said he was bothered by proven that it is not possible 10

Wils. "bargain" with then in a sale manuer.

Dr. John Anderson, administrater of the state Health Services Division. Sald that government surve's are needed to consuiners heeded warnings last and about how to cook and eat contaminated game birds. He said that if those warnings were ignored as these wans were innod as mere un han his or measures Andersongs may be necessary. heptachlor dangerous enough ro ban its heptachlor dangerous enough ro bantis

Rehniann, former director of Muntana Wildlife Federation, said sportsmen throughout the state remain confused and concerned about the afety of consuming game birds.

He said wildlife officials shouls publicize belter information before hunting season so sporismen becius. hunters are now spoced becaus. dilemma of eating polentially danger. dis substances or volentially danger. by discarding what they bag

Dick Fickler, who identified hinise as a Missoula iree farmer. said h asticide cerufication course and it was "a pke." He saic instructors appeared nol to lake the own directions seriously. 


\section{APPENDIX P}

Precautionary Poster Distributed to Hunting License Dealers and Others Prior to the 1981 Waterfowl Hunting Season in Montana, Showing Counties With Delayed Opening of Goose Hunting 


\section{WATERFOWL * HUNTERS *}

\section{ENDRIN CONTAMINATED WATERFOWL}

THIS MAP INDICATES WHERE YOU ARE MOST APT TO ENCOUNTER ENDRIN-CONTAMINATED WATERFOWL

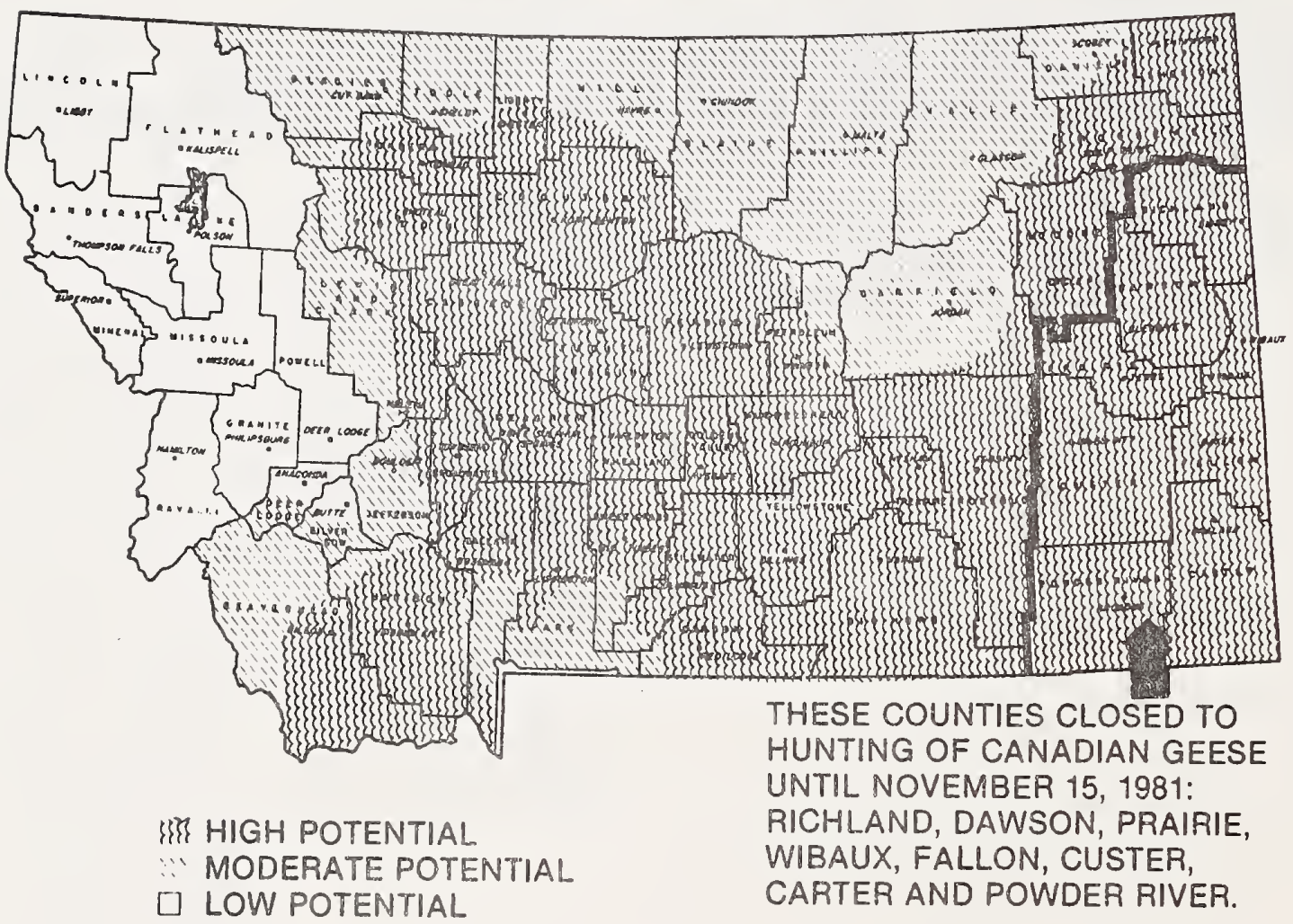

\section{RECOMMENDATIONS FOR COOKING - EATING WATERFOWL}

1. Trim ail fat and discard the skin and Internal organs. These Items should be discarded in a manner which will assure that they cannot be consumed by humans or domestlc or wlld animais.

2. Fully cook the skinned bird on a rack and discard the drlppings in the

same manner as fat, skin and organs.

3. Do not stuff birds.

4. Women who are pregnant or suspect they are pregnant, and nursing women should not consume waterfowl.

5. No more than one duck or one pound of goose meat per week nor more than slx ducks or slx pounds of goose meat per year should be consumed by adults. Chiidren's consumptlon should be IImlted to a half pound or less of meat at same intervals as those for adults. 


\section{APPENDIX Q}

Request of 4 National Organizations to The Environmental

Protection Agency to Cancel All Registrations for the Use of Endrin 


\section{NATIONAL WILDLIFE FEDERATION}

1412 Sixteenth Street, N.W., Washington, D.C. $20036 \quad 202-797-6800$

October 1, 1981

MEMORANDUM

TO: See Distribution

FROM: Jay D. Hair, Executive vice President Wht

RE: Endrin Action

The enclosed document was presented to the Environmental Protection Agency on 29 September 1981, by the National Wildlife Federation, the National Audubon Society, the Environmental Defense Fund, and the Izaak Walton League of America. I believe it will be of interest to you.

\section{DISTRIBUTION}

NWF Board and Staff

Montana Wildlife Federation

Colorado Wildife Federation

Wyoming Wildlife Federation

South Dakota Wildife Federation

Montana Dept. of Fish, Wildlife \& Parks

S. D. Dept. of Game, Fish \& Parks

Colorado Division of Wildlife

Wyoming Dept. of Game \& Fish

U. S. Fish \& Wildlife Service 


\section{National Audubon Society \\ NATIONAL CAPITAL OFFICE}

645 PENNSYLVANIA AVENUE, S.E., WASHINGTON, D.C. 20003 (202) 547.9009

September 29, 1981

The Honorable Ann Gorsuch

Administrator

Environmental Protection

Agency

401 M Street, S. W.

Washington, D.C. 20460

Dear Ms. Gorsuch:

The National Audubon Society, the Environmental Defense Fund (EDF), the National Wildlife Federation, and the Izaak Walton League of America hereby request the U.S. Environmental Protection Agency to cancel all registrations of endrin. Numerous incidents of endrin contamination of wildilfe and the environment as a result of legal applications in 1981 are only the most recent examples of serious problems presented by the continued use of this pesticide.

On July 31, 1975 Audubon and EDF petitioned EPA to cancel all registrations of endrin. Official comments were subsequently submitted to EPA throughout the rebuttable presumption against registration (RPAR) process of evaluating risks of uses of endrin from 1976-1979. In 1979 comments were submitted on EPA's decision to cancel uses on cotton and to reregister inter alia uses on small grains, grasshoppers and pine voles in apple orchards.

In EPA's final decision to reregister most uses of endrin, the following statement was made.

The Agency is aware that strict enforcement of

label restrictions may be impossible but believes

that, where its regulatory actions have been reasonable, an adequate level of compliance can be anticipated. Any substantial evidence that misuse has become a common practice would provide a basis for further regulatory action. (Position Document at 57 )

Since the 1979 final decision on endrin, there is new substantial evidence that even under controlled circumstances, contamination $\hat{I}$ the environment results from endrin applications. 
A New York report on contamination of wildiife following the 1977 emergency spraying of endrin was not taken into consideration at the time of EPA's review and final 1979 decision. The documented results of spraying of endrin in Montana and several other western states in 1981 also constitute new substantial evidence of the inevitable contamination of wildiffe from the legal application of this pesticide. All existing registrations of endrin are therefore called into question.

pine voles

Although EPA reregistered endrin for use against pine voles in apple orchards, the state of New York refused, after Iitigation, to remove endrin from the list of prohibited pesticides. The Supreme Court of the state of New York based its decision of August 11, 1980 largely on a report by the New Pork State Department of Agriculture and Markets on monitoring after an emergency use of endrin for pine voles in 1977. The report was pubIished shorty after EPA's reregistration decision in 1979. The author, Robert J. Mungari, disclosed that under certain soil conditions, application of endrin resulted in $40 \%$ remaining up to 14 years after the application. (Report at 13)

In regard to efiects on wildiffe, the Mungari report concluded at page 54 that:

Post-treatment concentrations of endrin residues on grass and humus samples appear quite high. Wildifie feeding on grasses and forbs, and/or drops could be exposed to acutely toxic levels of endrin within a relatively short time period. Snails and slugs as well as earthworms and other invertebrates normal iy have a tendency to concentrate pesticides within their bodies above the existing levels of their surrounding medium. These organisms become sources of secondary poisoning to other wildife organisms. Any animal accumulating residues within its body represents a potential risk to otber wildife forms that may directly or indirectly utilize it as a food source. Sub-lethal concentrations in pine voles or the gradual build up of resistance within the target organisms will increase the risk of contaniation to predator species. Persistent pesticide uptake in a large number and diversity of wildilfe species creates a dangerous reservoir of toxic materials to scavenger and predator species.

Audubon and EDF brought the Mungari report to EPA's attention in a January 17, 1979 letter. On August 19, 1980 Audubon and EDF requested EPA to reconsider use against the pine vole in apple orchards, based on the New York Supreme Court decision. The Mungari report and the court decisions constitute substantial new evidence not available at the time of the final EPA decision. EPA's review of the request is apparently still underway. (See Exhibit $A$ ) 
September 29, 1981

page 3

Small grains

The benefits of the use of endrin on small grains are very small and the risks continue to be very bigh. A slight elght percent of the U.S. wheat acreage receives any insecticide application annualiy so that small grains do not constitute an enormous use of any pesticide, including endrin. Moreover, EPA claimed that "market and consumer impacts are expected to be negligible if endrin is cancelled for use on wheat." (Position Document $2 / 3$ at 87 )

On the risk side, wildlife kills have been observed from use of endrin on wheat (EPA Transcript of hearings, Kansas City, Missouri, May 26, 1977), and on alfalfa in California (Position Document 4 at 13). The spraying of one million acres of wheat for army cutworms in Kansas and Oklahoma in 1976 resulted in hundreds of reports of fish kills, dead bald eagles, livestock kills, and the death of two prize greyhound dogs.

During the spring of $1981,120,000$ to 200,000 acres of wheat lands in 30 or more Montana counties were legally sprayed with endrin. (Exhibits $B$ and $C$ ). The Montana Departments of Agriculture, Fish, Wildlife and Parks, and Livestock predicted the "application of endrin can be reasonably expected to cause reductions in nontarget organisms." This prediction materialized with an initial fish kill in Sunday Creek (Miles City, Montana), in which the Department of Agriculture issued a violation citation to the applicator, and rumored deaths of wildlife in the actual areas sprayed. Also immediately, concern for the safety of endangered whooping cranes was voiced by the U.S. Fish and Wildlife Service (Exhibit D).

As of May 11, 1981, the state of Montana intitiated a program of monitoring the status of endrin (and toxaphene) residues at a limited number of sites. Copies of nine status reports filed through the period of September 4, 1981 are attached as Exhibits $E-M$. These status reports and Exhibit $C$ document endrin contamination of various species of upland birds, waterfowl, and other organisms. It is especially important to point out that numerous species of migratory birds, including several that will be harvested for human consumption, were found to carry unexpectedly high levels of endrin residues. The fact that their normal fall migration takes these birds through many other states and across international boundaries has focused attention on Montana's use of endrin.

W. Gordon Mcomber, the Director of the Montana Department of Agriculture, recognized the dangers of endrin and on September 4 , 1981, acting under state authority, issued an emergency rule temporarily suspending all uses of endrin for any purpose (Exhibit $N$ ). In the public notice on this rule, Mr. McOmber stated, "It is the consensus of this department and the Department of Fish. Wildlife and Parks that the introduction of more endrin into the environment of game birds should be avoided, particularly in view of the fact that acceptable substitutes are avail- 
September 29,1981

page 4

able" and furtber ". . . the department bereby finds that an imminent emergency exists which threatens public bealtb, safety and welfare. ." (Exbibit 0 ).

At an earlier date (August 27, 1981) the Montana Department of Health and Environmental Sciences recommended surveillance of endrin residues in "all game species" for a period of two to three years and that restricitons and warnings be continued during that period, or until the residue levels become "micro or undetectable." (Exbibit P). The Montana Department of Fisb, Wildlife and parks has issued warnings and had to consider closing some game harvest seasons. (Exbibit C).

While documentation is available from Montana, endrin was also sprayed in Colorado, Wyoming, South Dakota, and perhaps other western states. Reports should be reviewed from these states as the fall migration continues and monitoring proceeds.

The 1981 spraying and its documented effects constitute new substantial evidence of the unreasonable and continuing adverse effects of endrin.

\section{Grasshoppers}

On May I, 1981, Mr. Mcomber temporarily suspended the use of endrin for grasshopper control and imposed "more stringent control over endrin uses still allowed" due to the existence of an "imminent emergency" and threats to the "public bealth, safety and welpare. . ." (Exbibit Q). Treatment for grasshoppers is frequently in solid blocks of very large size, which impose significant short and long-term hazards for wildiife.

The bazards of endrin are well documented for use against grasshoppers in wheat and less hazardous insecticides are available. In western states wild animals as large as deer were poisoned by endrin following sraying on wheat. Incidents of Iivestock killed by endrin sprayed at low rates on wheat have been documented. Sheep have also died in convulsions from endrin sprayed on wheat.

Use of endrin against grasshoppers is unnecessary and should therefore be cancelled since acceptable substitutes are available. 
September 29, 1981

page 5

Additional problems

Tolerances. The current controversy over how much endrin contaminated game meat, if any, persons may safely consume has brought out once again the fact that tolerances or an exemption from tolerances bave not been established for endrin. (See Exhibit R). Endrin's use on small grains are designated as "extended no-residue registrations" which were to have been converted to registrations covered by tolerances after additional studies bad been completed.

The reason tolerances had not been established was that a "no-effect level" or acceptable daily intake (ADI) could not be determined. In 1978 EPA apparently arrived at a tentative ADI for endrin based on the Joint Expert Committee on Pesticide Residues use of the FAO/WHO no observable effect level for endrin in the dog at $0.025 \mathrm{mg} / \mathrm{kg} / \mathrm{day}$. Thus the acceptable or maximal daily intake for humans was established at $0.0002 \mathrm{mg} / \mathrm{kg} /$ body weight/day. Additional testing is apparently necessary to set finite tolerances or an official ADI.

Until that time, action levels allow residues in food. Action levels, however, constitute merely an enforcement number applied when no tolerances for a residue bas been established, but the presence of the residue poses a regulatory problem. The number is the limit of how much of a contaminant will be allowed in food before legal action is taken. The action level for poultry is $0.3 \mathrm{ppm}$ on an extracted fat basis, and $0.03 \mathrm{ppm}$ after all fat is removed. These levels are not safety levels. Consuming waterfowl or other game meat with such levels is close to, if not in excess of, what could be dangerous.

Metabolic fate in man. The problem of endrin's metabolism in man also remains unresolved, compounding the potential risk endrin poses for persons ingesting even small amounts. The 1975 study by D. H. Hutson et. aI. ("Detoxification and Bioactivation of Endrin in the Rat," Xenobotica, 5(11):697:714.) found that a bighly toxic metabolite, 12-ketoendrin, is produced in the rat, and this endrin metabolite is lipophylic. EPA's decision to reregister endrin for use on food is irresponsible considering the critical question that remains on whether or not 12-ketoendrin may occur in the adipose tissues of individuals exposed to endrin, and such residues have never been looked for in man or other animals.

Conclusion

The hazards of endrin are and will continue to be well documented as long as endrin remains available. Substantial new evidence now exists to cancel remaining registrations. The National Audubon Society, the Environmental Defense Fund, the 
September 29, 1981 page 6

National Wildlife Federation, and The Izaak Walton League of America therefore renew the 1975 petition that all registrations of endrin be cancelled.

Sincerely yours,

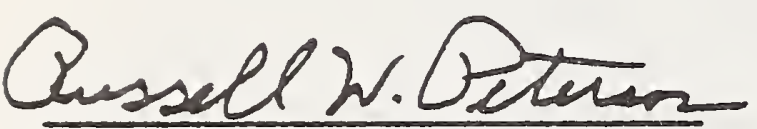

Russel1 W. Peterson

President

National Audubon Society

950 Third Avenue

New York, New York 10022

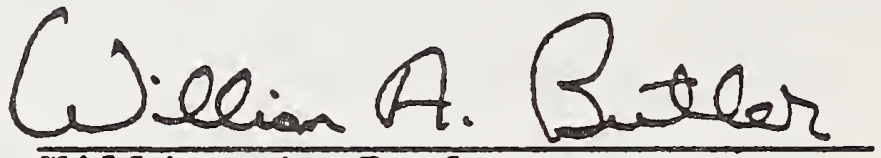

William A. Butler

Vice President for Government Relations and Counsel National Audubon Society 645 Pennsylvania Ave., S.E. Washington, D.C. 20003

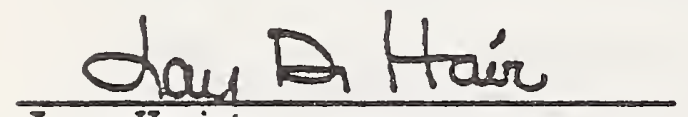

Jay Hair

Executive Vice President

National Wildlife Federation 1412 Sixteenth Street, N.W. Washington, D.C. 20036

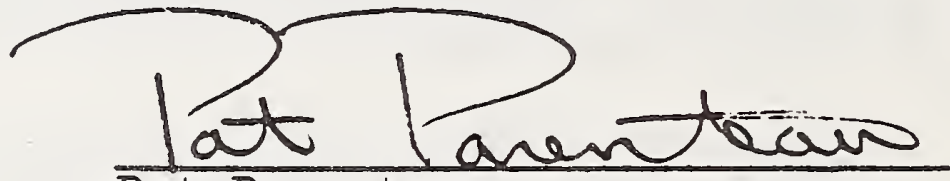

pat parenteau

Vice President for Resources Conservation Department

National Wildlife Federation 1412 Sixteenth Street, N.W. Washington, D.C. 20036

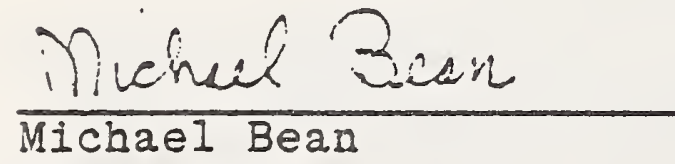

Director

Wildilie Program

Environmental Defense Fund 1525 18th Street, N.W. Washington, D.C. 20036

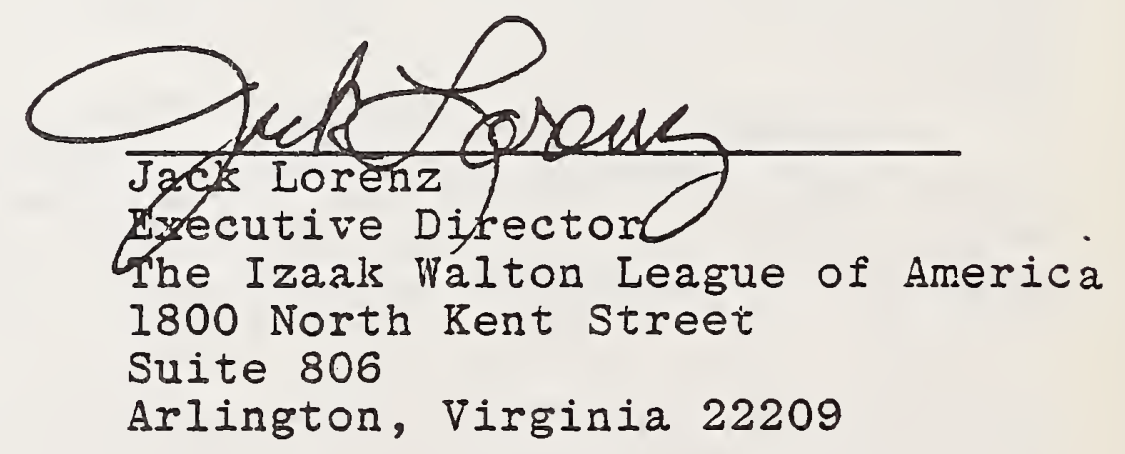

Suite 806

Arlington, Virginia 22209 


\author{
RESOLUTION OF THE \\ MONTANA FISH AND GAME COMMISSION \\ MARCH 13, 1983
}

WHEREAS, the Montana Fish and Game Commission recognizes that for as long as man has occupied this state, wildife and fish have been an integral part of human existence for reason of recreation and sustenance, and

WHEREAS, today Montana's wildlife and fish populations continue to represent a major asset to this state, being highly valued by the state's residents and all Americans who recognize the national significance of this resource, and

WHEREAS, agriculture is an important cornerstone in Montana's economy and as such is in need to exercise effective control over crop-threatening insects, and

WHEREAS, agriculture and wildlife can exist in harmony if safe, effective insect control chemicals are substituted for persistent compounds like the chlorinated hydrocarbons,

NOW, THEREFORE BE IT RESOLVED, that the Montana Fish and Game Commission requests federal and state pesticide regulatory agencies to authorize and recommend alternative pesticides that are more environmentally safe and less persistent than the chlorinated hydrocarbons which include endrin and heptachlor, and

BE IT FURTHER RESOLVED, that the commission supports the Environmental Protection Agency funding appropriate studies to evaluate the effectiveness of alternative compounds for endrin and other chlorinated hydrocarbons used in Montana and beg in an immediate phase-out of the highly persistent chlorinated hydrocarbons when alternatives are available. 

